\title{
A violência enquanto problema de saúde pública: percepções e possibilidades
}

Raquel Zaicaner

Tese apresentada ao Programa de Pós-Graduação em Saúde Pública para obtenção do título de Doutor em Saúde Pública.

Área de Concentração: Práticas de Saúde Pública

Orientador: Prof.Titular. Fernando Lèfevre

São Paulo

2007

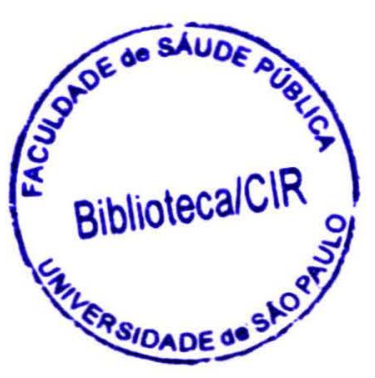


É expressamente proibida a comercialização deste documento tanto na sua forma impressa como eletrônica.

Sua reprodução total ou parcial é permitida exclusivamente para fins acadêmicos e científicos, desde que na reprodução figure a identificação do autor, título, instituição e ano da tese.

$$
4928412008 \text { dox }
$$




\section{DEDICATÓRIA}

A meus pais sempre, que me ensinaram o gosto pelo conhecer.

A minha filha Ruth, que tantas ausências minhas suporta e ainda por cima, compreende.

A meu marido Aurino, ausência que dói tanto, e que sempre me apoiou em todas as "minhas invenções", mesmo que com elas não concordasse.

A Profa Evelyn Naked Castro de Sá, pelo estímulo, presença, cobrança e confiança. 


\section{AGRADECIMENTOS}

Ao Prof. Titular Fernando Lèfevre, pela confiança, apoio e estímulo, mesmo nos momentos em que nem eu conseguia acreditar que chegaria ao final.

A Prof. ${ }^{a}$ Ana Lèfevre, mestra de todas as horas, incentivadora, que não me deixou desistir desse projeto, mesmo nos momentos em que eu quis desistir de tantos outros.

A Cidinha, Livia, Daniel e todo o pessoal do departamento, pelo apoio, torcida e ajuda, sempre.

A Renilda e Cidinha pelo apoio e carinho.

A Lacir Baldusco, Prefeito de Itapecerica da Serra à época desse estudo, amigo de todas as horas.

A Dra. Maria Rosa Logiodice Cardoso, Dra. Cláudia Maria Chagas, Dra. Kimy Otsuka Stavestkas e Dra. Alexandra Cristina Pitol de Lara Basso, pelo apoio, incentivo, ajuda braçal, ouvido atento e ombro amigo.

A todos os entrevistados, que muito me ensinaram não apenas sobre o tema do estudo, mas da arte de viver. 


\section{Resumo}

\section{Zaicaner, R. A Violência Enquanto Problema de Saúde Pública: Percepções e}

Possibilidades. São Paulo;2007. [ Tese de Doutorado - Faculdade de Saúde Pública da USP ].

O objetivo deste estudo é o de compreender as percepções sobre a violência da população de Itapecerica da Serra - SP. Nossa motivação inicial foi ser esta cidade apontada na grande imprensa como a mais violenta do Estado de São Paulo.

Conhecer o que pensam as pessoas desta cidade, como enxergam o papel da saúde no enfrentamento deste problema, e em que maneira o conhecimento das idéias que permeiam este coletivo pode orientar políticas públicas para o setor.

A partir da definição de homicídio enquanto evento sentinela, visto ser indiscutível sua associação à violência, foram levantados os óbitos por homicídio ocorridos no município de Itapecerica da Serra no ano de 2002, quanto a algumas características demográficas e sociais como sexo, idade, estado civil, escolaridade em anos de estudo, causa básica, local de residência e local de ocorrência do evento que causou o óbito.

Para a identificação dessas informações, foram utilizadas duas fontes primárias de informação: a declaração de óbito e boletim de ocorrência.

Foram realizadas entrevistas abertas em quatro grupos distintos: familiares de vítimas de violência, formadores de opinião, profissionais de saúde e um quarto grupo que foi denominado de protagonistas da violência. 
Foi utilizado o instrumental metodológico de Discurso do Sujeito Coletivo (Lèfevre\& Lèfevre) que propicia o entendimento do pensamento das coletividades enquanto realidades complexas.

Foram pinçadas dos diversos discursos, idéias e sugestões para seu enfrentamento, de forma a analisar sua possivel utilização na formulação de políticas públicas.

Descritores: Violência, Homicídios, Discurso do Sujeito Coletivo, Representações Sociais. 


\section{Abstract \\ Zaicaner, R. Violence as a Public Health Problem: Perceptions and Possibilities.}

The aim of this study is to understand and discuss the perceptions of violence in Itapecerica da Serra - São Paulo. This city was pointed out by press as the most violent city of all São Paulo State.

We wanted to understand what the inhabitants of this city think about the role of the Health Sector in this area and yet, how this understanding can be used to construct public policies.

Homocides were taken as the event that conducted the study, since it is impossible disagree that this is, in fact, violence.

We studied the deaths caused by homicide in Itapecerica da Serra - São Paulo , in 2002.

Some epidemiological characteristics were studied such as sex, age, civil state, yeas of study, cause of death, residence and occurrence address. We used two sources of information: Those provided by the Declaration of Death, provided by Health system and the Occurrence Bulletin, provided by the Police system.

Interviews with open questions were conducted with four different groups: Family member's of homicide victims, opinion makers, The health professionals and a fourth group formed by protagonists of violence.

We used the methodological tool called "Discourse of the Collective Subject" (Lèfevre\& Lèfevre), that approximates the understanding of collective thoughts as complex realities. 
We identified in these speeches ideas and suggestions to analize the possibilities to use them to construct public policies.

KEY WORDS: Violence, Homicide, Discourse of the Collective Subject. 


\section{ÍNDICE}

1. Introdução 10

1.1 Panorama de morte, horizonte de vida 10

1.2 Algumas considerações sobre a violência 18

1.3 Violência e representação social 20

1.4 Globalização e sociedade de consumo e de informação 22

1.50 individualismo e a perda da coesão social 24

1.6 Espaço/Território: Sua utilização desigual e relações

Com a violência $\quad 25$

1.7 Exclusão Social e Violência 27.

1.8 Cidadania e Educação 31

1.9 Violência e Saúde Pública: Uma via de duas mãos? 33

1.10 Caracterização do Município 37

2. Objetivos 46

2.1 Objetivo Geral $\quad 46$

2.2 Objetivos Específicos $\quad 46$

3. Metodologia $\quad 47$

3.1 Revisão Bibliográfica $\quad 47$

3.2 Identificação dos casos de homicídios no município

De Itapecerica da Serra em $2002 \quad 47$

3.3 Utilização do Discurso do Sujeito Coletivo para

Obtenção das representações sociais 49

3.4 Escolha dos sujeitos 51

3.5 Apresentação dos entrevistados 53

3.6 Coleta e transcrição dos dados 56

3.7 Tabulação dos dados e organização dos discursos $\quad 58$

4. Resultados 59

4.1 Homicídios em Itapecerica da Serra -SP em $2002 \quad 59$ 
4.2 Os discursos e suas Representações

65

4.3 Estratégias de Enfrentamento da violência 117

5. Análise e Discussão 119

6.Considerações Finais 128

7. Referências Bibliográficas 133

8. Anexos 143

8.1 Anexo I: Termo de Consentimento Livre e Esclarecido 144

$\begin{array}{ll}8.2 \text { Entrevistas } & 145\end{array}$ 


\section{Introdução}

\subsection{Panorama de morte, horizonte de vida.}

Não obstante a importante conquista da Saúde Pública no que tange à grande redução nas taxas de mortalidade infantil, nos deparamos com 0 assombroso crescimento das taxas de mortalidade por homicídio. Jovens com idade entre 15 e 19 anos, correspondem a $87,6 \%$ de todos os casos de vítimas por homicídio no Brasil (PERES, CARDIA, SANTOS, 2006), sendo 5\% destes casos ocorridos com crianças de até nove anos de idade.

O Terceiro Relatório Nacional sobre os Direitos Humanos no Brasil afirma que a violência fatal continua a atingir, intensa e principalmente, jovens do sexo masculino das grandes cidades e regiões metropolitanas. Em todo o Brasil, as mortes por homicídio por 100mil habitantes, entre jovens com 15 a 24 anos aumentaram de 26,71 para 27,01 de 2000 para 2004. Os estados com este índice mais elevado, em cada região são: Rondônia (38,0/100mil), Pernambuco (50,7 /100mil), Mato Grosso (31,6/100mil), Espírito Santo (49,1/100mil), Rio de Janeiro (49,1/100mil) e Paraná (28,0 /100mil) (NETO, ALVES, 2007).

A violência, tanto em regiões urbanas como rurais, é agravada pela violência policial. Torturas e execuções exercidas por membros da polícia são praticadas em todos os estados do país, sobretudo em São Paulo e Rio de Janeiro (NETO, ALVES, 2007). Apesar das sindicâncias e processos administrativos, investigações criminais e processos judiciais, raramente se obtêm os nomes dos responsáveis e menos ainda, punição dos culpados, à semelhança do Massacre de Carandiru em 1992 em que o único policial condenado teve anulada esta condenação e recebeu absolvição em fevereiro de 2006. Esta impunidade se estende a executores e mandantes de crimes contra lideranças sociais, políticos e jornalistas. 
Por outro lado, é sabido e debatido o fato de que há, em áreas urbanas e rurais, bolsões praticamente sem lei, à margem do estado de direito. Também se tem conhecimento sobre as contratações de policiais, promotores, juízes, construções de delegacias, prisões, mais voltadas para interesses político eleitorais do que de fato à construção do estado de direito. $O$ obstáculo não se situa tão somente na falta de vontade política dos governantes, mas na falta de capacidade política e técnica para desenvolver políticas de direitos humanos. Ainda que diversos aspectos contribuam para este déficit de democracia, o Terceiro Relatório Nacional sobre direitos Humanos no Brasil (NETO, ALVES, 2007) aponta para dois deles:

A incapacidade política de promover o diálogo e a cooperação entre organizações governamentais e destas com organizações da sociedade civil e movimentos de direitos humanos, definindo prioridades, objetivos e estratégias integradas para a proteção e promoção dos direitos humanos.

A incapacidade técnica de processar e empregar na formulação $e$ implementação de políticas, a enorme quantidade de dados e informações sobre direitos humanos, produzidos e distribuídos por organizações governamentais $e$ não governamentais, pelos mais diversos meios de comunicação, desde a transição para a democracia.

É de se espantar que a situação de mortes por homicídios tenha se agravado exatamente no período de consolidação da democracia brasileira. Com o retorno do estado de direito, as violações motivadas pela repressão política diminuíram, mas os atentados aos direitos civis, o crime organizado e práticas violentas arbitrárias, tanto da população, como de corporações, como da polícia, persistiram e aumentaram. Mais espantoso ainda é sabermos que além desta brutalidade recair principalmente em dorsos jovens, a intensidade com que isto acontece é imensa se considerarmos que este não é um país que enfrenta guerra ou insurreição armada. 
As mortes ocorrem freqüentemente em lugares onde CÁRDIA (2006) e equipe de pesquisa apontaram existir uma "superposição de carências de todos os direitos socioeconômicos", um contexto inibidor do convívio sem conflito e violência. Mesmos lugares onde se concentra a criminalidade organizada, onde 0 dia a dia das pessoas comuns está submetido ao controle dos grupos criminosos que possuem seus entrelaçamentos com escalões que operam em outros níveis, como os aparelhos estatais, como denunciam os jornais e CPIs no Congresso.

A seguir, a apresentação de alguns dos resultados principais apontados pela pesquisa sobre Homicídios de Crianças e Jovens no Brasil 1980-2002 (PERES, CÁRDIA e SANTOS, 2006).

De 1980 a 2002 a maior parte dos homicídios no Brasil ocorreu no Nordeste e Sudeste do país, principalmente em São Paulo, Rio de Janeiro e Pernambuco. Os números das mortes ocorridas, essencialmente os que incidem na faixa etária de 15 a 19 anos, superam o número de mortes por acidentes de trânsito. Para cada óbito feminino, encontramos oito masculinos e $59 \%$ dos homicídios são cometidos por arma de fogo. As taxas muito altas ou muito baixas de homicídios, encontradas durante o período pesquisado, desvelaram discrepâncias de dados compreendidas como resultante de subnotificações de óbitos, o que, por sua vez, indica uma subestimação deste tipo de óbito no país.

Dentre as graves violações dos direitos humanos, como a execução sumária, linchamento e violência policial, $14 \%$ são cometidos contra crianças e jovens de até 19 anos. No Rio de Janeiro, ficou demonstrado que as violações atingem um pouco mais as meninas e crianças menores do que em outras capitais do Brasil.

As execuções sumárias ocorrem geralmente em locais abertos e públicos, especialmente em vias públicas (no Brasil como um todo e em São Paulo) e em 
favelas (no Rio de Janeiro). Em locais fechados, a maior parte ocorreu em residências e delegacias.

A pesquisa (PERES, CÁRDIA e SANTOS, 2006) aponta ainda que, no âmbito do Rio de Janeiro, o principal motivador destas execuções tem como entorno o envolvimento com drogas e/ou jogo do bicho. Em São Paulo, a maior parte é motivada por roubo e/ou seqüestro relâmpago. Ainda em São Paulo, o $\mathrm{CMH}$ (coeficiente de mortes por homicídio) cresceu quase $300 \%$ de 1980 a 2002 , quando seu valor atingiu 20,3 por mil habitantes, representando então o terceiro maior da região sudeste e o quarto maior do país.

BICUDO (1997) aponta para a necessidade da modificação do papel da polícia, com a necessidade da sua melhor preparação para que se transforme em ator da paz na sociedade e não como é reconhecido, um ator da violência.

Por outro lado, pesquisa sobre o adolescente na criminalidade urbana em São Paulo, realizada pelo Ministério da Justiça (ADORNO, 1999) aponta que não houve grandes transformações nos movimentos de delinqüência juvenil no período estudado (1988-91 e 1993-96). Este estudo afirma existir uma curiosa incongruência entre os fatos e as percepções coletivas sobre o tema, estas últimas tendendo a crer em uma criminalidade juvenil violenta, incontrolável e crescente, ao passo que a observação empírica da realidade social não sustenta tal idéia. O perfil do adolescente infrator não se distancia do perfil de outros adolescentes e aqueles são recrutados entre os que vivem como a maior e esmagadora parte dos adolescentes desta sociedade. Ambos experimentam semelhantes processos de mudanças em curso para adolescentes.

Contudo, há dois dados que podem apontar, ainda que sutilmente, para mudanças no comportamento: primeiro, a redução percentual de adolescentes inseridos no mercado de trabalho e segundo, o crescimento da escolaridade média na caracterização do perfil do jovem infrator. A pesquisa sobre 0 
adolescente na criminalidade (ADORNO, 1999) levanta a hipótese que setores dos estratos sociais médios estão contribuindo com seus adolescentes para 0 quadro da delinqüência juvenil. O que reforça a importância, comprovada tal hipótese, das políticas direcionadas ao assunto passarem a focar necessidades, demandas sociais e psicológicas que reclamam adolescentes com distintas inserções sociais e histórias particulares de vínculos às classes sociais. Em um momento em que a redução da maioridade penal cria tanta polêmica, grande número de juízes desconhece o Estatuto da Criança e do adolescente, o que dificulta um sistema efetivo de proteção (PERES, CÁRDIA e SANTOS, 2006).

Com respeito à evolução da criminalidade não violenta para a violenta e um maior envolvimento dos jovens com o crime organizado, foi observado um maior percentual de infrações violentas cometidos por adolescentes do que pela população urbana em geral. A hipótese explicativa deste estudo (ADORNO, 1999) considera que, não havendo grandes mudanças das modalidades infracionais, os adolescentes que adentram mais precocemente no mundo do crime se tornam mais violentos "contribuindo assim para inflacionar a criminalidade violenta". Contudo, levando-se em conta esta hipótese como verdadeira, faz-se conseqüente pensar sobre a tendência ao fracasso das políticas de atendimento aos jovens infratores, a forma indiferenciada com que tratam aspectos como diferenças de idade ou diferentes graus de envolvimento com o crime. Acrescenta que este cenário de crescimento da delinqüência juvenil no Brasil ao logo dos anos 80 e início dos anos 90 não se revela um fenômeno isolado, também temos igual panorama em outras sociedades do mundo ocidental capitalista, como Inglaterra e França, para falar em Europa e Estados Unidos e Canadá, para mencionar América do Norte.

No bojo da reflexão acerca do mundo moderno coloca-se imprescindível questionar quais são as formas de inserção dos jovens no mundo social atual, caracterizado "... por extremas desigualdades sociais, pelas dificuldades de acesso aos direitos civis e sociais e de acesso às instituições promotoras de 
justiça e de bem estar, a despeito das mudanças sociais que vem ocorrendo no curso desta década que incidem precisamente sobre o lugar e a participação dos jovens" (ADORNO, 1999,).

O Relatório de cidadania (SALLA, 2002) é um dos resultados do Observatório, constituído de testemunhos sobre temas relacionados aos direitos humanos, de quatro grupos de jovens, três da região sul de são Paulo e um da região de Itapecerica da Serra. Testemunhos que não apenas observaram, mas também interpretaram e avaliaram enquanto sujeitos inseridos no contexto que observam.

Este estudo revela que as formas de violação dos direitos humanos possuem aspectos comuns: são pouco denunciadas, raramente investigadas e quase nunca julgadas e punidas. Certamente, esta falta de expectativa diante da justiça, unida ao temor e descrédito pelas instituições promotoras de segurança, gera agravantes para este mesmo quadro de violência. Muitos crimes permanecem desconhecidos, muitos crimes são resolvidos por meio de outros crimes, através da "justiça com as próprias mãos" ou apoio dos chamados matadores de aluguel, muitas vítimas são tratadas como culpadas e sofrem violência por parte dos policiais, gerando mais medo e o silêncio de valiosos testemunhos, enfim, um grande círculo vicioso da violência protegendo e estimulando o crescimento e recrudescimento da violência.

BICUDO (2003) nos fala sobre os direitos humanos, no âmbito da pessoa humana. Ressalta não ser possível, se não em um Estado democrático, um regime de liberdade individual e de justiça social.

Aponta a desinformação e descrédito quanto às possibilidades de apoio para o enfrentamento da violência sofrida: “... sejam eles os jovens agredidos pela polícia, ou as meninas violentadas, não conhecem nenhum caminho para se 
defender ou pedir qualquer tipo de apoio. E, mesmo que alguns saibam que têm direitos, eles não acreditam que seja possível defende-los" (SALLA, 2002,).

Estes jovens observadores do Relatório de cidadania falam também da importância em facilitar para os jovens o acesso à atividades culturais e promover o entendimento de "cultura" não apenas como ferramenta de combate à violência, mas como ferramenta de obtenção de conhecimento, promoção de prazer e, sobretudo, o exercício de um direito assim como moradia, saúde e educação.

Para Itapecerica da Serra, região focada pela presente pesquisa, o Relatório de Cidadania (SALLA, 2002) observou a faceta emprego - desemprego como um dos prismas do complexo sistema da violência. Os sérios obstáculos enfrentados pelos jovens para a obtenção de emprego e as sérias dificuldades enfrentadas por quem já empregado. O estudo afirma que os programas responsáveis por inserir jovens no mundo do trabalho têm um alcance limitado não só pelo número reduzido de vagas que oferecem, mas também pela alta demanda por empregos, bastante superior ao número de vagas disponíveis na região. Contam que existe a barreira da discriminação por cor de pele e origem social, contraditoriamente ao que os programas visam combater: Há aqueles que têm a vaga negada sob a justificativa de morarem em bairros violentos, distantes, periféricos, próximos a favelas. Consideram que os diferentes programas, deveriam integrar mais suas ações, criar uma maior articulação entre órgãos públicos e empresas, otimizar a divulgação e acessibilidade de suas propostas e criar cursos de formação efetivamente úteis, diverso de muitos que existem (SALLA , 2002).

Por fim, o quarto grupo de observadores do Relatório de cidadania (SALLA, 2002), aborda o tema educação e escola. Aponta aí que há uma visão segmentada e corporativa dos dirigentes e professores acerca dos direitos humanos, limitando a proposição de diálogos e a busca de soluções para os conflitos existentes no interior do espaço escolar. Relatam que "... a falta de um 
projeto educativo competente não lhes permite criar uma consciência crítica, mas só reproduzir a realidade... O jovem daqui não tem expectativas para o futuro, não vislumbra caminhos para sair desta condição, não se permite sonhar com uma vida mais digna, não acredita na transformação" (SALLA, 2002). Indicam como essencial para a mudança deste quadro de desesperança a superação das barreiras para o exercício do direito à educação, desde o que tange à qualidade deste ensino até a reflexão e mudança do próprio modelo da escola pública.

Em 2000, 1,6 milhão de pessoas no mundo perdeu a vida devido à violência; perto de um terço deste número devido a homicídios (OMS 2002). As taxas de morte violenta variam segundo os niveis de renda do país. Em países de baixa renda são mais que o dobro do que em países de renda alta. Na região Africana e na região da Américas, as taxas de homicídio são aproximadamente três vezes maiores que as taxas de suicídio (OMS 2002).

Em todos os países, à semelhança do que vimos para o Brasil, os rapazes são os principais perpetradores e vítimas de homicídio. "Contudo, a maioria dos jovens que têm comportamento violento só tem tal comportamento durante um período de tempo mais curto, durante a adolescência e, quando crianças deram pouca ou nenhuma evidência de tal comportamento. Tais 'delinqüentes limitados à adolescência' muitas vezes procuram excitar-se, e os seus atos violentos são freqüentemente cometidos na companhia de um grupo de amigos. Os jovens também têm tendência para se envolver em uma vasta gama de comportamentos anti-sociais, cometendo mais delitos não violentos (grifo meu) do que delitos violentos. Entre jovens com comportamento violento e delinqüente, álcool, drogas ou armas faz aumentar a probabilidade de haver lesões ou mortes associadas a violência" (OMS 2002).

A violência pode ser prevista e evitada ainda que seja complexo e difícil estabelecer uma relação direta das causas e efeitos. A identificação e avaliação 
de todos estes aspectos mencionados contribuem para a tomada de decisão e para uma construção conjunta de ações.

Certamente o empenho político é vital na luta contra a violência e supressão dos direitos humanos e, para lograr tal empenho, faz-se necessário esforços incessantes além da integração dos vários setores de nossa sociedade, de governos a empresas, de comunidades a grupos de reunião espontânea, de indivíduos que se juntam para agir em conjunto. Isto pode fazer diferença e transformar esta realidade.

\subsection{Algumas considerações sobre a violência}

Violência não é um fato novo. Existe desde os primórdios da humanidade. $A$ Bíblia conta vários episódios desta natureza descritos desde a criação do mundo com a "mutilação" de Adão para fazer a mulher, passando pelo fratricídio envolvendo Caim e Abel e tantos outros eventos.

A história segue farta de exemplos: as cruzadas, inquisição, guerras mundiais, o holocausto, massacres étnicos e tantos outros perpetrados em nome da fé, da posse de terras, do poder, da honra, de conflitos raciais e tantas outras justificativas.

Apesar da longa convivência, ela tem chamado a atenção de todos e em nosso caso específico, no Brasil. O que será que mudou? Ou ainda, será que alguma coisa mudou? SCURO, 1998, refere que durante o século XX, pelo menos em dois outros momentos: os anos 30 e os anos 70, os índices de crimes violentos atingiram dimensões assustadoras; o que preocupa é que o atual ciclo não mostra sinais de arrefecimento. 
Ao lado da violência concreta, vem o sentimento de insegurança que abala a confiança em um porvir, em sonhos e na construção de projetos pessoais. Hoje crime e violência são encarados como problemas sociais, violações a normas que a sociedade aprova ou aceita.

Este processo sugere uma banalização da vida que atinge, em especial, os segmentos mais vulneráveis. O envolvimento de crianças e adolescentes no crime, leva à crença de estar todo o tecido social embebido pela violência e criminalidade. SCURO nos apresenta ainda o dado de que $50 \%$ de todos os crimes são cometidos por $6 \%$ da população, composta de infratores reincidentes; a outra metade fica por conta de pessoas que nunca tiveram problemas com a lei.

Não queremos limitar a compreensão deste fenômeno apenas pelo viés da criminalidade e desvio normativo. Seria uma visão estreita e limitada, apesar destas facetas serem importantes no aprofundamento do tema. Sua multicausalidade impõe um olhar igualmente múltiplo para que possa ser conhecido e enfrentado.

O problema que nos perturba é: Em sendo a violência um fenômeno histórico e atual, envolto em uma gama de questões e subjetividades, em relação ao qual, propostas, as mais variadas, são lançadas diariamente como capazes de enfrentar o problema, por que então este ciclo da violência não tem respondido às políticas públicas postas em curso? Será que os fundamentos utilizados para a sua elaboração levam em conta o que as pessoas pensam a este respeito? $E$ mais, será que se levados em conta são capazes de instrumentalizar a elaboração de propostas que tenham maior impacto no enfrentamento do problema?

$\mathrm{Na}$ configuração da violência cruzam-se problemas de diversas naturezas, Como por exemplo: da política, economia, moral, filosofia, direito, antropologia, psicologia e outros. Vamos procurar fazer algumas aproximações de temas como a globalização e sociedade de consumo e de informação, individualismo e perda de coesão do tecido social, exclusão social, o espaço/território e a violência e 
ainda a importância do tema para a saúde pública e desta para o assunto em pauta.

\subsection{Violência e representação social}

A violência não pode ser tratada de forma fatalista. É sempre um caminho possível em contraposição à tolerância, ao reconhecimento e à civilização. Faz parte da própria condição humana, porém aparece de forma peculiar em sociedades específicas.

MINAYO, (1994) apresenta uma classificação que apesar de bastante geral, procura não reduzir o problema à mera questão da delinqüência. Segundo esta classificação, teríamos a violência estrutural, a de resistência e a de delinqüência.

A primeira faz referência ao comportamento e se aplica tanto a estruturas organizadas e institucionalizadas da família como dos sistemas econômicos, culturais e políticos que conduzem à opressão de grupos, classes, nações, e indivíduos, aos quais são negadas conquistas das sociedades, tornando-as mais vulneráveis que outros ao sofrimento e à morte". Tem grande capacidade de "naturalizar" a violência.

A segunda seria representada pelas diferentes formas de resposta destes grupos, indivíduos, nações oprimidos à violência estrutural. Ao contrário da primeira, geralmente sua ação não é "naturalizada", mas contestada pelo poder político, econômico e cultural, sendo objeto de controvérsias entre filósofos, sociólogos, políticos e do homem comum.

A terceira está nas ações fora das leis e normas sociais reconhecidas e aceitas. Sua análise remete à compreensão da violência estrutural que não só 
confronta os indivíduos uns com os outros, mas também os corrompe e impulsiona ao delito. (MINAYO, 1994)

DA MATTA (1982, apud Minayo, 1994) recomenda que o estudo da violência seja feito seguindo metodologia relacional e dialética, adotando-se uma perspectiva histórica de análise, que considere sua dinâmica no tempo e espaço, sem perder de vista seu caráter abrangente e universal. Recomenda que seja evitado o viés valorativo e normativo, entendendo-a não apenas como um mal, mas como desafio para a sociedade; e enfim sugere relacionar o crime à norma, 0 desvio à regra, o conflito à solidariedade, pois revelam as formas de propriedade do governo, bem como às leis do mercado.

A representação social pode ser traduzida como o senso comum, sendo capaz de nos aproximar do tema pelo lado dos atores sociais. JODELET, 2001 nos traz as representações sociais como sendo fenômenos complexos sempre ativados e em ação na vida social. Em sua riqueza é possível identificar diversos elementos como informativos, cognitivos, de crenças, valores e atitudes, ideológicos e de opinião, organizados sob a forma de um saber que diz algo sobre a realidade. É este significante que nos interessa.

CHESNAIS, (1981) distingue no discurso contemporâneo três definições implícitas de violência que contemplam tanto seu caráter individual como coletivo. São a física, a econômica e a moral e simbólica. A primeira atinge diretamente a integridade física como os homicídios, agressões, violações. A segunda consiste no desrespeito à propriedade e seus bens; a terceira, à dominação cultural que desrespeita os direitos dos outros.

Texto escrito por SOARES e CARNEIRO em 1996, interpretando uma pesquisa de opinião realizada pela Rede Globo de Televisão com a população carioca revela existirem, segundo critérios daquela população, quatro nomes para a violência: crime, pecado, corrupção e miséria. Crime é a violência reduzida à 
delinqüência; pecado, a violência interpretada por códigos religiosos, expressando a natureza ambivalente e passivel de perversão do homem. Corrupção aponta para a traição de valores, e miséria enxerga a violência pela ótica da política como conseqüência da desigualdade e exclusão.

Para MINAYO (2003), na estrutura do pensamento popular existe a certeza de que a violência é parte e resultante das relações, da comunicação, da vida social. Apesar de designada como um saber ingênuo ou do senso comum, é reconhecido pela comunidade científica como legítimo objeto de estudo, dada a sua importância na visão social e por ser capaz de elucidar processos cognitivos e de interação social.

Através das representações sociais podemos apreender a difusão e assimilação de conhecimentos, definição de identidades e transformações sociais. É um saber prático que liga um sujeito a um objeto com o qual desenvolve relação simbólica e interpretativa.

\subsection{Globalização e sociedade de consumo e de informação}

A globalização tem aspectos que precisam ser destacados. No mundo globalizado, espaço e tempo ganham novas dimensões, são virtuais. Não há mais barreiras para o intercâmbio cultural, a informação, o conhecimento. Os avanços tecnológicos permitem desvendar mistérios antes insondáveis da vida humana e social; a democracia atinge grande parte das nações.

Ao nos colocar no mundo da técnica, do conhecimento, da informação, escamoteia questões ideológicas. Ao conhecermos, ou pensarmos conhecer o mundo, tomamos contato com a competitividade que cria uma tensão permanente, apresentada como o único caminho a seguir. 
O mundo globalizado se exime do ensino e cultivo das chamadas humanidades, reduzindo o poder de crítica e autocrítica (MILTON SANTOS, 2000). A tecnologia e cientificismo, ícones do mundo globalizado, estão também relacionados à capacidade do homem de criar e gerar objetos, vinculado ao mito do pecado original da tradição judaico-cristã da curiosidade, do desejo de ser Deus. A possibilidade de criação em série, da constante recriação, favorece a exacerbação da sociedade de consumo.

O consumo passa a ser contemporaneamente, um definidor fundamental da sociedade, substituindo o princípio da produção (LÈFEVRE,A., mimeo,2004). Enquanto na modernidade procurava-se a produção em série que atendesse às necessidades ou desejo de consumo do homem "médio", num mercado de massas, o avanço da tecnologia permite a criação do mercado de consumo individualizado, característico deste momento da contemporaneidade das sociedades capitalistas denominado de pós-modernidade.

A separação e distanciamento entre tempo e espaço é uma característica importante da globalização. O lugar pode ser ao mesmo tempo vários espaços diferentes. A separação do homem de seu próprio espaço permite que ele viva dimensões simultâneas sem necessariamente deslocar-se do local onde se encontra ( LÈFEVRE,A. mimeo,2004)

A sociedade de informação é conseqüente a este fenômeno. A velocidade da informação é capaz de modificar a cultura mundial impondo hábitos, novos padrões de consumo, desenhando um novo mundo. Ao mesmo tempo em que é apresentado como fenômeno mundializado, reproduz ciclos de exclusão já sedimentados no mundo "real". 


\subsection{0 individualismo e a perda da coesão social}

A constituição da idéia do homem como cidadão de direitos foi construída na modernidade, baseada em princípios iluministas. No Brasil, apesar de nunca ter se completado, esta construção se dá dentro da concepção de Estado de Bem Estar, e a criação do Sistema Único de Saúde é um bom exemplo.

Estes princípios têm como contra - princípios aqueles que buscam definir de forma hegemônica a vida como uma competição onde o objetivo é ganhar sempre, sendo a responsabilidade do ganhar ou perder, individual. Os perdedores são estigmatizados como incapazes no jogo social.

Num mundo de tão acirrada competitividade, onde a ordem é ganhar a qualquer preço, resta pouco ou nenhum espaço para a coesão social, mantida por vínculos de solidariedade e pertencimento que não encontram possibilidade de resistência na pós - modernidade de indivíduos atomizados e sós.

Paradoxalmente, assistimos a uma luta entre estes princípios, que buscam ser hegemônicos, e uma contraposição representada pela reemergência do religioso em contraposição à ciência e tecnologia e dos crescentes movimentos de solidariedade social que se contrapõem aos princípios do "winners and losers".

Neste contexto, a cultura de paz propõe mudar a lógica onde para que um ganhe é necessário que alguém perca, sugerindo o paradigma do ganha/ganha. Trabalha com o princípio da tolerância e da aceitação das diferenças. 
1.6 Espaço/Território: Sua utilização desigual e relações com a violência

Para MILTON SANTOS, 2000, o espaço deve ser entendido enquanto produto social em permanente processo de transformação em diferentes períodos históricos. Destaca a importância de relacionarmos a ocupação do espaço e localização dos centros de decisão, frente à sociedade, enquanto gerador de tensões.

O território não deve ser considerado um conceito em si mesmo e sim, a partir de seu uso. A competitividade estimulada pela globalização, leva a uma busca de maior produtividade que depende das condições oferecidas nos lugares de produção, circulação e consumo. Assim, os lugares passam a ser essenciais, assumindo papel inédito na dinâmica social.

O crime se beneficia de todas as facilidades do mundo globalizado, de seus aparatos tecno-científicos e de comunicação. Na mesma lógica anteriormente apresentada, buscam lugares que ofereçam situação privilegiada para a produção, circulação e consumo. Faz sua gestão de forma capilarizada e em rede, com veloz circulação financeira. A partir da década de 90 , temos as guerrilhas urbanas de narcotraficantes apoiadas em sistemas de circulação e troca de produtos ilegais como armas e drogas, e de lavagem de dinheiro, que seguem a mesma lógica da globalização e se realizam em conluio com a ilegalidade, com o envolvimento de pessoas e instituições acima de qualquer suspeita ( MINAYO,2003 ).

Ao seguir a lógica globalizante, cresceu e floresceu em regiões e espaços economicamente dinâmicos onde processam e reproduzem as grandes operações capitalistas. Hoje o tráfico de drogas e armas é a maior atividade econômica no mercado mundial, com alta rentabilidade financeira ( MINAYO,2003 ). 
SANTOS propõe a utilização dos termos espaço e território indistintamente, destacando a importância do diálogo da sociedade com o território usado. Pontua a cidade como espaço multidimensional, que reúne pessoas das mais diversas origens, níveis de instrução, riquezas e entendimentos, onde é possível interpretações mais corretas do mundo e do próprio lugar. Identifica nas cidades uma riqueza de perspectivas, questionamentos, desejos, vontade de ultrapassar a própria situação que pode se manifestar pela violência, entendida pelo autor como um discurso peculiar à sociedade em que vivemos que também aponta para uma vontade de entendimento e superação.

RAQUEL ROLNIK, 1999, nos chama a atenção para a existência de contrastes profundos entre condições urbanas, muitas vezes dentro da mesma cidade como é o caso do centro e periferias das cidades. Estes contrastes das condições urbanas são a tradução das desigualdades de oportunidades urbanas, que expressam diferenças econômicas e sociais.

Para a autora, a exclusão territorial (termo cunhado dada a sua identificação com exclusão social) condena toda a cidade a um urbanismo de risco, marcado pela insegurança quer do terreno, quer da construção ou ainda da condição jurídica da posse daquele território. As terras onde se desenvolvem estes mercados de moradia para os pobres são, normalmente, justamente aquelas que pelas características ambientais são as mais frágeis, perigosas e difíceis de ocupar com urbanização: encostas íngremes, beiras de córregos, áreas alagadiças.

A inadequação de domicílios, característica da exclusão territorial, torna indivíduos, famílias, comunidades vulneráveis, abrindo espaço para a violência e conflito. Esta exclusão bloqueia o acesso a empregos, oportunidades educacionais e culturais que estão concentradas nas regiões centrais. 
Estudos sobre a violência mostram seu aumento em anos subseqüentes a grandes crescimentos populacionais. Na Região Metropolitana de São Paulo, o grande crescimento populacional se deu nos anos 70 e 80 . A partir da década de 90, temos uma explosão da violência nestas áreas, o que coincide com estarem os jovens nascidos então, com idade de disputar o mercado de trabalho, após passar toda a sua vida em situação de vulnerabilidade, falta de oportunidades, de capital simbólico e de projetos de vida.

\subsection{Exclusão social e violência}

Exclusão Social é conceito de caráter ambíguo que vai desde ser resultante de inadaptação individual, até injustiça e exploração social. Sua ambigüidade faz com que muitas vezes seja enfocado por apenas uma de suas características. A análise centrada no econômico usa o termo como sinônimo de pobreza; a centrada no enfoque social como discriminação.

Bader Sawaia, 2001 propõe que seja tratado enquanto injustiça social. .Aborda a exclusão sob a perspectiva ético-psicossociológica, entendendo-a como processo complexo sócio-histórico. Discute ser mais adequado chamá-la de inclusão perversa. Em lugar da exclusão, o que se tem é a relação dialética entre exclusão/inclusão.

Esta concepção introduz, na análise sociológica da desigualdade, a ética e subjetividade, não estando limitada a questões de empregabilidade ou crise do Estado. Na análise psicológica, desatrela-a da noção de adaptação e normatização. Revela o processo da culpabilização individual. (SAWAIA, 2001,). Esta dialética gera subjetividades que vão desde sentir-se incluído até 0 sentimento de discriminação e revolta. 
A exclusão só existe em relação à inclusão. Envolve o homem por inteiro em seu mundo relacional. RENÉ LENOIR,( apud WANDERLEY,2001) destaca como origens da exclusão o rápido e desordenado processo de urbanização, a inadaptação e uniformização do sistema escolar, o desenraizamento causado pela mobilidade profissional, as desigualdades de renda e de acesso aos serviços, que não atinge apenas à franja dos subproletários, mas que cada vez mais atinge todas as camadas sociais.

XIBERRAS (apud WANDERLEY, 2001) diz serem os excluídos todos aqueles que são rejeitados de nossos mercados materiais ou simbólicos, de nossos valores, trazendo para o conceito o não reconhecimento de riquezas espirituais, de valores simbólicos.

Vivemos a crise do Estado de Bem Estar Social, com a tendência neoliberal de diminuição da ação social do Estado, que se acompanha da crise de solidariedade e do vínculo social. Temos um número cada vez maior de pessoas fora do mercado de trabalho por despreparo para as novas funções que se apresentam o que tira o caráter temporário, perenizando a situação de exclusão para um contingente que só aumenta.

Para ALDAİZA SPOZATTI (apud WANDERLEY, 2001), a exclusão não é um processo individual embora atinja pessoas, mas de uma lógica que está presente nas várias formas de relações econômicas, sociais, culturais e políticas da sociedade brasileira...Ela inclui pobreza, discriminação, subalternidade, não equidade, não acessibilidade, não representação pública. É importante ressaltar não serem pobreza e exclusão sinônimos, apesar de serem faces da mesma moeda. A representação do pobre está cada vez mais relacionada à do bandido marginal.

A análise da exclusão não pode ser dissociada da questão da democracia já que é vinculada à privação de poder e de representação. A naturalização do 
fenômeno da exclusão leva à sua reprodução com aceitação tanto a nível social quanto individual, revelando a fragilização dos vínculos sociais. Este processo transforma direitos em favores das elites dominantes.

ZIONI, (2006) faz ampla revisão sobre exclusão social e analisando o trabalho de autores como PAUGAM, TOURAINE, D'ALLONDANES, CASTEL, discorda de uso deste termo enquanto categoria explicativa e a adota como noção-entendida como elemento inicial de processo de conhecimento.

ADORNO (2005), também nos fala desta fraqueza conceitual do termo por falta de articulação mais ampla com teorias da sociedade.

Apesar de todas as críticas à utilização de exclusão social enquanto conceito e a banalização de seu uso, devemos nos aproximar deste termo pela sua importância na discussão das desigualdades.

ZIONI (2006), aponta LENOIR como primeiro autor a utilizar o termo excluído, mesmo que apenas no título do seu livro, mas tendo o mérito de trazer para o debate a concepção de exclusão não mais como fenômeno da ordem individual mas social, cuja origem deveria ser buscada nos princípios mesmos do funcionamento das sociedades modernas. Trata a exclusão como fenômeno social com suas origens na forma como a sociedade esta organizada, com seu processo de urbanização capaz de promover segregações sociais e raciais, enfraquecimento de vínculos de solidariedade familiares, acesso a cuidados e outros fatores característicos das sociedades modernas.

Alguns autores discutem a exclusão como um processo de afastamento das populações menos qualificadas, entretanto observa-se que a exclusão afeta um número cada vez maior de pessoas, com um risco para diversos grupos frente à conjuntura econômica e crise do emprego. 
ZIONI (2006) traz o comentário de XIBERRAS de exclusão como um processo que atinge muitas pessoas em qualquer situação social. ROSANALTONN trabalha exclusão associando-a a desagregação do tecido social, a vulnerabilidade.

Exclusão ligada à pobreza mas não limitada a esta. Relacionada a questões de trabalho enquanto mecanismo de manutenção regular de acesso à bens e serviços. Relacionada também as transformações do trabalho desde a flexibilidade de suas relações até a transformação de trabalhador da era industrial ao das atuais exigências de ser dotado de mobilidade e capacidade de adaptação.

PAUGAM discute a exclusão enquanto estigmatização, com origem na Europa do pós-guerra com baixo acesso a moradia, onde os "excluídos" ou inadaptados eram acomodados em conjuntos habitacionais construídos para estas populações, que tiveram como desdobramento a desconfiança de comerciantes e empregadores frente a estas pessoas.

Nos parece muito importante e resgate deste referencial que apesar de remontar a outra realidade, Europa pós-guerra, pode encontrar um paralelo nos nossos conjuntos habitacionais direcionados a populações de baixa renda e aos "bairros" construídos nas periferias das grandes cidades.

Apesar de diferentes olhares a questão do não acesso ao trabalho está na gênese da exclusão.

OLIVEIRA (1997) compartilha a idéia de que a precarização das relações de trabalho esta na base da exclusão, lembrando entretanto sua utilização para enquadrar minorias como negros, homossexuais, deficientes físicos, loucos, pobres e favelados. 
Lembra, assim como NASCIMENTO (1994) que a incorporação de novas tecnologias torna desnecessário, tanto do ponto de vista da produção como do consumo, grandes contingentes populacionais, o que amplifica o tempo em que um trabalhador passa do momento de exclusão (desemprego) para o de inclusão. (MARTINS, 1997)

Qualquer que seja a corrente de pensamento adotado, não se pode ignorar que a amplitude do tema faz com que a presença do Estado seja fundamental ao seu enfrentamento.

KOVARIK (2003) traz a questão da naturalização das conjunturas estruturais e relações sociais que levam à pobreza, onde o destino de cada um é fruto do acaso, do que sempre foi. Traz também a discussão do mecanismo de neutralização que busca desenvolver fórmulas de separação, de se evitar o contato com a população pobre. Pobreza essa cujo crescimento é associado à violência urbana.

\subsection{Cidadania e Educação}

O ser humano é concebido para viver em sociedade e não como um ser isolado (DALLARI, 2000). A vida em sociedade envolve um conjunto de direitos e deveres que permitem a convivência dentro de um espaço (BYDLOWSKI, 2005). A estas regras de convivência chama-se cidadania, conceito que se modifica ao longo do tempo.

Surgido na Grécia e Roma antigas, trazia na sua concepção direitos políticos enquanto privilégio de poucos: evolui com a incorporação de princípios de igualdade e liberdade enquanto alicerces da cidadania, sendo associado aos direitos sociais. (BYDLOWSKI, 2005), 
COHN (2003) nos traz a transformação destes direitos sociais e individuais quando se perde a noção de cidadania, que é substituída pelo exercício do direito do consumidor.

É a constituição que define e garante quem é cidadão e que direitos e deveres terá.

A constituição de 1988, conhecida como Constituição Cidadã, é promulgada com a garantia de direitos de cidadania a todos os indivíduos natos ou naturalizados no país. A cidadania não pode mais ser vista apenas enquanto um conjunto de direitos formais. JACOBI (2002) propõe uma nova qualidade de cidadania com sujeitos sociais ativos.

A educação sempre esteve ligada à construção da cidadania. A Grécia Antiga nos traz o mito de Prometeu acorrentado, onde por ter dado ao homem comum o acesso ao fogo enquanto símbolo do conhecimento, nosso herói foi condenado ao suplício de ser acorrentado a um rochedo onde diariamente era supliciado com a retirada de um pedaço do seu fígado. Seu crime foi de dar ao homem comum o acesso ao conhecimento, destinado apenas aos deuses.

A educação, o acesso ao conhecimento esta intimamente ligado à participação na vida política e ao poder. A ausência de educação pode ser uma forte arma para o domínio dos poderosos (DEMO, 2001).

A escola não é o único espaço onde se dá a educação nem tampouco o único caminho para a cidadania, o que é assumido pela Lei de Diretrizes Básicas da Educação (LDB, 1996). BYDLOWSKI, 2005 identifica para as escolas importante papel no desenvolvimento e formação do cidadão, discute a estrutura desta escola e do ensino, o sistema e clima de relações sociais, padrões de autoridade e exercício da liberdade. Aponta o professor como eixo central da 
formação do aluno enquanto cidadão, que se espelha na forma como o professor se comporta.

Para DURKHEIM (1997) a escola aparece como uma das instituições constituidoras do ser social dos indivíduos e, enquanto tal, possibilita a manutenção e a reprodução da ordem social.

\subsection{Violência e saúde pública: uma via de duas mãos?}

A partir dos anos 80 , as taxas de mortalidade por causas externas aumentam em todo o país ocupando o segundo lugar entre todas as causas de mortes no país (GAWRYSZEWSKI, KOIZUMI e MELLO-JORGE, 2000). Em 2000 são aproximadamente 120 mil mortes anuais, 630 mil internações e um impacto financeiro para o SUS de pelo menos $R \$ 351$ milhões por ano. É determinante no menor crescimento da esperança de vida ao nascer. Suas mortes e seqüelas ameaçam de forma epidêmica a qualidade de vida e bem estar. É uma guerra silenciosa que vitima em sua maioria homens, jovens e adolescentes.

YUNES E RAJS (1994) realizam estudo em que analisam mortes por causas externas na população de 10 a 24 anos, nos países da América, no período de 1979 a 1990. Dos 15 paises participantes cujos dados permitem análise e comparação, apenas três mostram tendência francamente crescente em todas as faixas etárias e na de 10 a 24 anos. São eles o Brasil, Colômbia e Cuba. No Panamá e Porto Rico esta tendência crescente é observada na população geral e no Uruguai apenas na população de 10 a 24 anos.

Para os outros países participantes: Argentina, Canadá, Costa Rica, Chile, Estados Unidos da América, México, Suriname, Trinidad-Tobago e Venezuela, a tendência é descendente em todas as faixas etárias. O Uruguai aponta tendência 
decrescente na população geral e Panamá e Porto Rico para a faixa etária de 10 a 24 anos.

AGUDELO (1990) afirma: $A$ violência representa um risco maior para a realização do processo vital humano: ameaça a vida, altera a saúde, produz enfermidade e provoca a morte como realidade ou como possibilidade próxima.

A magnitude do problema chama a atenção de toda a sociedade e da saúde em particular que passa a reconhecê-lo como um problema de saúde pública. Em 2003, a Organização Mundial de Saúde (OMS) define a violência como tema oficial para a comemoração do Dia Mundial da Saúde. A Organização Panamericana de Saúde (OPAS), em sua $111^{\text {a }}$ Reunião do Comitê Executivo, realizada em Washington entre os dia 28 de Junho e $1^{\circ}$ de Julho de 1993, discute o tema da violência, onde afirma: As condutas violentas na região das Américas constituem um grande problema de saúde publica e são causa de deterioração da qualidade de vida. Suas conseqüências para a saúde e o bem estar das coletividades, seu equilíbrio social e sua estabilidade econômica se reveste de proporções alarmantes (YUNES E RAJS, 1994). Elabora Plano de Ação Regional dando prioridade ao tema. Reconhece ser a saúde pressionada pelas vítimas da violência em seus serviços de urgência, atenção especializada e de reabilitação física, psicológica e de assistência social.

Será este o único papel do setor saúde frente à violência? Receber e tratar suas vítimas? Acreditamos ter a saúde pública papel muito maior nesta questão, entendendo sua relação com o tema como uma via de mão dupla. Possui potencial maior dada a sua natureza que se relaciona com diversos saberes, buscando conhecer, compreender o problema e apontar caminhos para o seu enfrentamento.

MELLO-JORGE (1980) aponta a necessidade, do ponto de vista da saúde pública, de conhecer as características, alcance e distribuição das mortes 
violentas de forma a possibilitar a formulação de programas visando sua prevenção.

As investigações realizadas continuam centradas em estudos de mortalidade. MELLO-JORGE (apud MINAYO,1994) aponta uma certa assepsia na sua classificação entre as "causas externas", incapaz de expressar seus conteúdos essenciais. Dados sobre violência são por natureza problemáticos, provisórios e tentativos, não podendo mesmo pretender traduzir a verdade.

Apesar destas ressalvas, os estudos epidemiológicos permitem apontar a magnitude do problema, em especial os de mortalidade. Revelam seu crescimento exponencial. O Brasil ocupa o terceiro lugar entre os países com maior mortalidade por homicídio. Estes dados gerais sofrem grandes modificações quando nos debruçamos sobre suas diferentes causas como acidentes, suicídios e homicídios. Esta última é a que mais cresceu no período, associada ao uso de arma de fogo.

No Brasil no ano 2000 foram 45.343 vítimas de homicídio (GAWRYSZEWSKI, KOIZUMI e MELLO-JORGE, 2000) o que corresponde a 124 pessoas assassinadas/dia. Isto resulta em coeficiente de $26,7 / 100.000$ habitantes (35,1 para homens e 4,3 para mulheres). Entre estas mortes as autoras apontam que $63,5 \%$ foram causadas por armas de fogo, no Brasil como um todo. Entretanto em São Paulo e Recife, armas de fogo foram responsáveis por mais de $90 \%$ dos homicídios.

Por envolver aspectos conflitivos nas relações sociais, padece ainda de subnotificação. As implicações legais fazem com que muitas vezes tanto as informações médicas quanto as policiais as coloquem numa classificação geral de "outras violências", dificultando o seu melhor conhecimento. Existe ainda um problema anterior que é a não notificação dos casos, em especial nos de extermínio em que as vítimas fatais desaparecem sem deixar vestígios. 
Os estudos de morbidade têm sido ainda mais difíceis de serem realizados por diversos fatores como o de notificação dos casos, quer por não utilização de serviços públicos, não sensibilização da equipe de saúde para o problema, quer por pressão por parte das vítimas, parentes ou interessados que procuram evitar transtornos legais.

Todas as dificuldades metodológicas de obtenção de dados, construção de indicadores de saúde em violência e em homicídios em particular, devem, ao invés de desestimular o pesquisador, mobilizá-lo a encontrar caminhos a trilhar para estudar um problema que, por suas dimensões de pandemia deve ser priorizado em saúde pública.

YUNES E RAJS (1994) propõem ações do setor saúde para a prevenção de mortes por causas violentas. Destacam a promoção à saúde com papel preponderante na abordagem de fatores psicossociais, redução dos acidentes de trânsito, de trabalho, consumo de álcool e drogas psicoativas, da violência nas relações intra-familiares e comunitárias num processo de participação intersetorial. Propõem ainda ações específicas do setor saúde como: educação em massa da população sobre o cuidado inicial ao traumatizado; criação de atendimento préhospitalar adequado; definição da capacidade resolutiva de todos os níveis de atenção do sub-sistema; eliminação de todas as barreiras econômicas e geográficas para o atendimento ao traumatizado; instalação de sistema de vigilância epidemiológica para as causas violentas; formulação de protocolos clínicos para todos os níveis de atenção; implantação de rede de serviços de emergência dotados de recursos adequados aos diferentes graus de gravidade das lesões; criação e integração de serviços de reabilitação e capacitação dos profissionais de saúde.

O Ministério da Saúde lança sua Política Nacional de Redução de Morbimortalidade por Causas Externas através das portarias MS/GM737 de 16 de 
Maio de 2001 e MS/GM 344 de 19 de Fevereiro de 2002. A primeira trata dos princípios, diretrizes e responsabilidades institucionais. A segunda destaca seus objetivos específicos, descreve algumas ações, seu monitoramento e avaliação e ainda, as parcerias.

Têm como princípios a saúde enquanto direito humano para o desenvolvimento social e econômico; o direito à vida e a promoção da saúde como base das ações a serem desenvolvidas. Destaca o papel do Ministério da Saúde enquanto gestor e articulador das ações intersetoriais.

A leitura destas portarias deixa claro estarem consonantes com o plano de ação regional proposto pela OPAS.

A junção dos esforços de diversos atores sociais e utilização dos diversos saberes devem levar em conta o pensamento social não só dentro de um contexto histórico-político-econômico e social, mas também em seus contextos simbólicos para a construção de propostas de atuação.

\subsection{Caracterização do município}

Este estudo foi realizado no município de Itapecerica da Serra (IS), localizado na região metropolitana de São Paulo.

O Aldeamento de Itapecerica surge de uma decisão estratégica da Companhia de Jesus, para servir como posto avançado para defesa e posto de vigilância contra incursões inimigas de seu posto central, o Colégio de Piratininga. Isto aconteceu no final do século XVI, no ano de 1562.

Situada em área montanhosa, com altitude de 1000 metros acima do nível do mar, sem nenhum rio importante navegável, com solo pobre e pouco profundo, 
sofreu agricultura predatória, devastação contínua da mata para servir de expansão urbana à capital.

A dificuldade de comunicação entre os povoamentos mantinha suas populações isoladas.

O acesso à Aldeia de Pinheiros só aconteceu em 1687. As estradas só foram construídas na segunda metade do século XX. A BR 116, conhecida como Rodovia Régis Bittencourt foi inaugurada em 1960 por Juscelino Kubitschek, fazendo com que Itapecerica deixasse de ser fim de um caminho.

Seu destino é intimamente ligado ao da capital, que dela tira a comida, o carvão combustivel, a madeira para construção, os tijolos, e o próprio solo para construir.

Sua população é constituída por diversos movimentos migratórios, desde a transferência dos índios da Aldeia de Carapicuíba, colonos alemães trazidos pela Princesa Leopoldina com o objetivo de criar um núcleo rural moderno com mãode-obra não-escrava. Seguiram-se outros, desta vez de estados brasileiros como os do sul do país, Minas e estados nordestinos.

Seu nome tem origem no Tupi, e significa Pedra Lisa. Foi apenas em novembro de 1944 que adota a denominação Itapecerica da Serra.

Em 1979, é criada a Lei de Proteção de Mananciais. Itapecerica da Serra tem $100 \%$ de seu território em área de preservação de mananciais. Nas duas últimas décadas o modelo de desenvolvimento econômico predominante foi o industrial, atividade econômica vedada aos municípios com terras sob esta legislação. Isto é determinante em seu processo desenvolvimentista. 
Apesar da intenção preservacionista em detrimento do crescimento econômico, o que se viu foi a explosão demográfica à custa de migrações, com ocupação desordenada do território.

Este inchamento da cidade ocorreu por migração de diversas regiões do país, no sonho do emprego e melhor condição de vida, acenado pelo crescimento da cidade de São Paulo de onde foram expulsos pela exploração imobiliária.

Estudo realizado em 1996, tendo 1991 como data zero para contagem populacional, pela Fundação IBGE - Agregado de Setores - mostrou que a movimentação populacional tem como principal origem o deslocamento interno no Estado de São Paulo, numa acentuação da periferização da pobreza, com o maior distanciamento da população de baixa renda do centro produtor. Esta migração interna é seguida dos provenientes da Bahia, Pernambuco, Minas Gerais e Ceará. Este mesmo estudo mostra uma média de 3,96 moradores por domicílio. No ano 2000 , apenas $43,12 \%$ dos domicílios apresentavam infra - estrutura interna urbana adequada, enquanto a média estadual é de $89,29 \%$.

É uma cidade dormitório com cerca de um quarto de sua população economicamente ativa, com alguma forma de garantia do sustento da família, o que não significa emprego regular.

Empurrados para as cidades vizinhas em suas regiões periféricas, formam novos núcleos populacionais em espaços de ocupação irregular, às margens dos mananciais que estariam sendo preservados.

Esta ilegalidade na ocupação do solo tem diversas conseqüências. É uma situação naturalmente violenta na medida em que a manutenção da moradia no mais das vezes, é sustentada à força; Por ser ocupação irregular não pode receber infra-estrutura urbana como luz, água, asfalto, rede de esgoto; o processo de regularização destes espaços não é tranqüilo. 
Em 2000, a coleta de lixo cobria $96,18 \%$ do município, com abastecimento de água de $85,90 \%$.

Estes espaços de ocupação estão em sua maioria, na terceira geração. Outros, mais recentes, na segunda e até primeira geração. Vários já tiveram a regularização, mas seguem divorciados de suas culturas, seus valores originais, não os tendo "substituído" por novos, na construção de uma identidade própria, do pertencimento.

É no período de 1980 a 2000 que o município sofre aumento descontrolado de sua população que passa de 60.000 habitantes em 1980 para mais de 120.000 habitantes em 2000. A este aumento de mais de $100 \%$ da população, não correspondeu incremento nas condições urbanas, de arrecadação municipal ou de ampliação da oferta de serviços públicos em geral e de saúde em particular. Em 2006, tem população de 169.022 habitantes.

A cidade faz divisa com os municípios de Embu-Guaçu, Embu, Cotia, São Lourenço e São Paulo. Com este último faz fronteira com uma região pouco provida de recursos institucionais e grande população ( 550000 hab.).

Esta região reúne bairros conhecidos nos noticiários policiais como Jardim Calu, Capela, Jd. Ângela, Nakamura e vários outros. Para moradores destas regiões, abandonados durante muitos anos pelo poder público, muitas vezes a cidade de Itapecerica da Serra se mostra uma opção mais fácil para obtenção de serviços que sua própria cidade, em especial na saúde, em situações de urgência e emergência. A conurbação é tão presente que muitos não sabem se tratar de diferentes cidades.

Ao analisarmos alguns indicadores de saúde, como o de mortalidade infantil, observamos que em 1995 o município apresentava coeficiente de 34.8 
mortos para mil nascidos vivos, enquanto a média estadual era de 24,6. A partir de 2002 o município consegue alcançar coeficiente melhor que a média do estado, conforme pode ser obsenvado abaixo, que volta a ser maior que a média estadual em 2005.

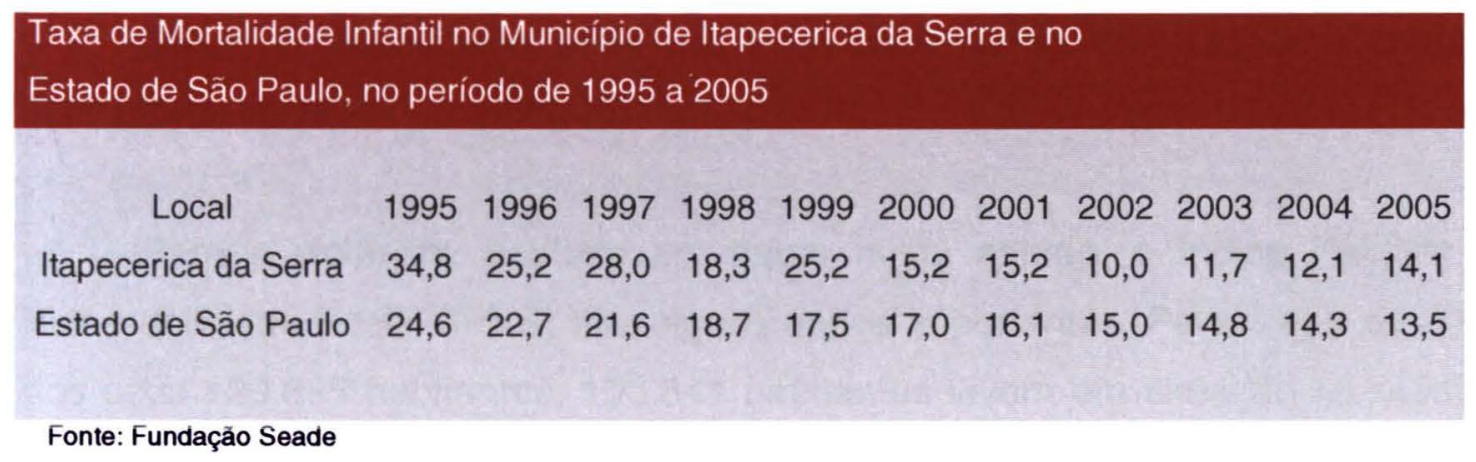

Está colocado em $288^{\circ}$ lugar no ranking estadual do IDHM (Índice de Desenvolvimento Municipal), que é de 0,754 para o ano de 2000. O IDHM é calculado utilizando critérios como os de Educação (Alfabetização e Taxa de Matrícula), Longevidade ( Esperança de vida ao nascer), e Renda( PIB per capita).

O índice varia de zero a um, sendo considerado até 0,499 baixo desenvolvimento humano, e a partir de 0,800 , alto desenvolvimento humano. $O$ município de Itapecerica da Serra apresenta IDHM de 0,783 para o ano 2000; o que significa índice de desenvolvimento humano médio.

Outro índice utilizado para análise do município é o IPRS (Índice Paulista de Responsabilidade Social), que analisa também em sua composição as condições de renda, longevidade e escolaridade, criando um índice que varia de 1a 5 , sendo os municípios classificados dentro de cada grupo, sem contudo ordená-los. Itapecerica da Serra apresenta IPRS de 2, em 2004.

Grupo 1: Municípios com nível elevado de riqueza e bons níveis nos indicadores sociais. 
Grupo 2: Municípios que embora com níveis de riqueza elevados, não exibem bons indicadores sociais.

Grupo 3: Município com nível de riqueza baixo, mas com bons indicadores nas demais dimensões.

Grupo 4: Municípios que apresentam baixos níveis de riqueza e nível intermediário de longevidade e/ou escolaridade.

Grupo 5: Municípios mais desfavorecidos, tanto em riqueza como nos indicadores sociais.

Para a violência, assunto em pauta neste estudo, o Índice Paulista de Vulnerabilidade Social (IPVS) traz alguns dados importantes. Para o ano de 2000, dos seus 129.685 habitantes, 103.841 habitantes vivem em situação de média a muito alta vulnerabilidade social; os anos médios de estudo do responsável pelo domicílio são de 5,4 e este tem uma renda média de $\mathrm{R} \$$ 604,00 (Seiscentos e quatro reais), quando no grupo de muito alta vulnerabilidade o rendimento médio do responsável pelo domicílio é de $\mathrm{R} \$ \mathbf{4 0 6 , 0 0}$ ( Quatrocentos e seis reais ).

O Índice Paulista de Vulnerabilidade Social trabalha com percentual da população sem vulnerabilidade para os itens estudados. Cabe destacar que esta cidade não possui em nenhuma das variáveis estudadas percentual da população com nenhuma vulnerabilidade. Este estudo foi realizado pela Fundação SEADE para todos os municípios do Estado de São Paulo.

Apresenta taxa de crescimento populacional, no período de 2000 a 2006 de 4,58. Elevado, quando comparado ao estado de São Paulo que é de 1,52. Este crescimento acontece às custas de processos migratórios.

Sua população é distribuída irregularmente pelos seus $136 \mathrm{Km}^{2}$, com regiões de alta concentração demográfica como é o Parque Paraíso, com densidade populacional de 15.000 habitantes $/ \mathrm{Km}^{2}$ e áreas de baixa concentração 
de população como é o Potuverá com pouco mais de 100 habitantes $/ \mathrm{Km}^{2}$. Em 2005 , tem densidade demográfica média de $1.194,47$ habitantes $/ \mathrm{Km}^{2}$.

Apresenta no ano de 2005, grau de urbanização de $99,14 \%$, enquanto que para o estado de São Paulo, esta taxa é de 93,65\%. No mapa da cidade observamos que sua urbanização se deu de forma nucleada, sendo estes núcleos separados do centro. Estes núcleos foram formados a partir da migração da cidade de São Paulo, expulsos pela explosão imobiliária, que empurra para cada vez mais distante do centro das cidades. O município foi dividido em quinze regiões administrativas.

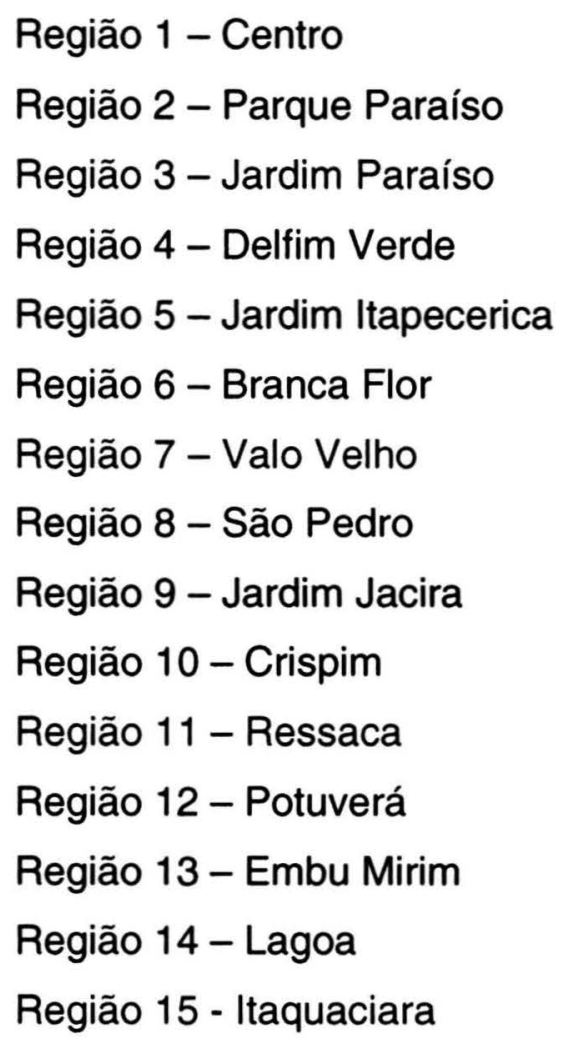




\section{Mapa do Município de Itapecerica da Serra}
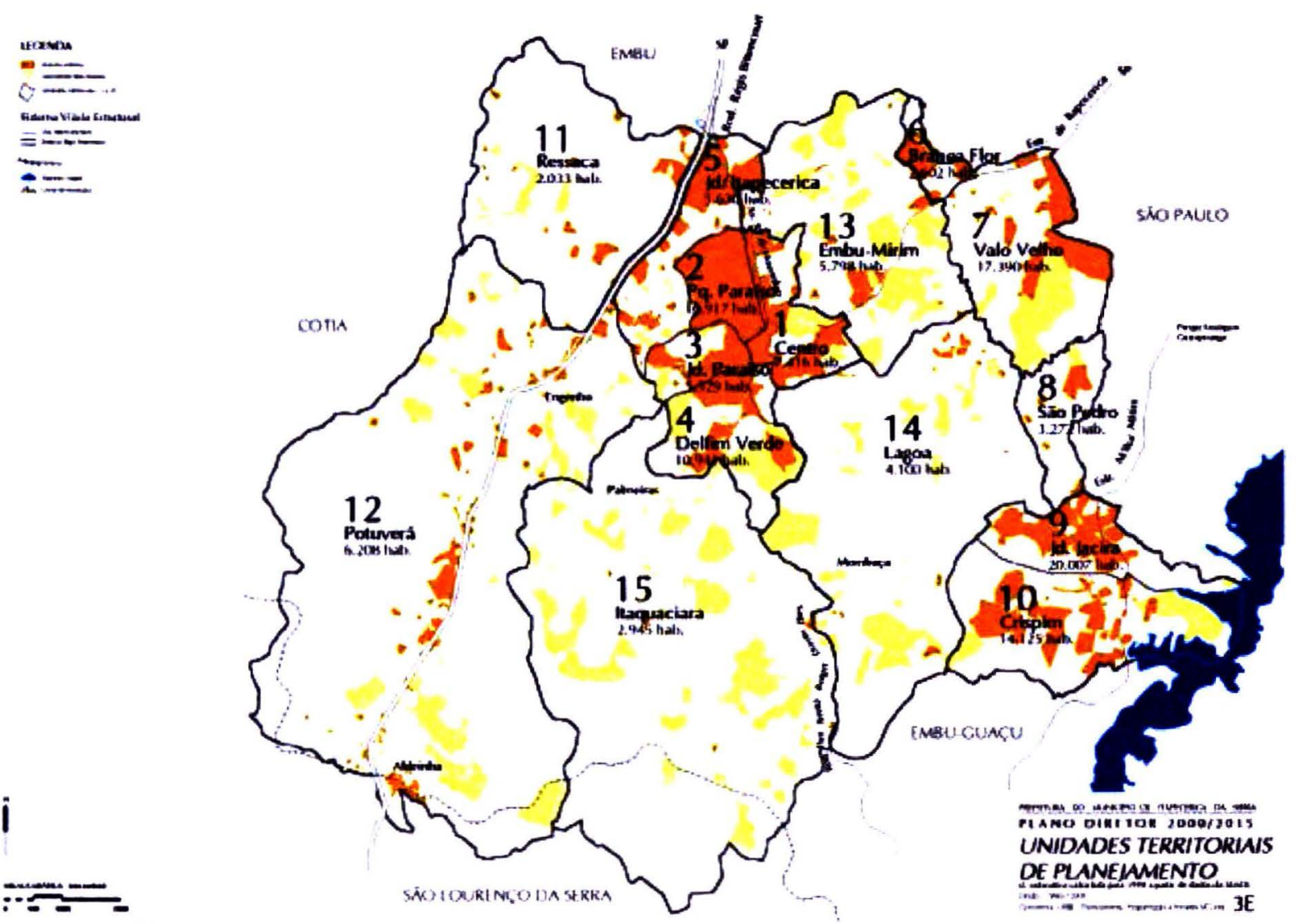

A área da saúde trabalha desde 1994 com base em processo de territorialização, com definição de áreas de responsabilização para cada unidade de saúde, que não correspondem exatamente às áreas administrativas. São estas as unidades de saúde e suas áreas de responsabilização: 
UNIDADE BÁSICA DE SAÚDE

UBS Branca Flor

UBS Crispim

UBS Jardim Jacira

UBS Parque Paraíso

UBS Potuverá

UBS Salvador de Leone

UBS São Pedro

UBS Valo Velho

UBS Mombaça

\section{ÁREAS}

6

10

9

2

$7,11,12,15$

$1,3,4,5,13$

8,14

7

14 ( parte )

A rede de serviços de saúde tem, além das unidades básicas de saúde, já descritas, dois pronto socorros, localizados um na região do Centro e outro no Jardim Jacira, uma maternidade municipal localizada na região central e um hospital geral estadual que serve de referência aos municípios da região. Mesmo com esta estrutura de saúde, que é recente, visto que o hospital geral foi inaugurado em 1999, apresenta relação de leitos hospitalares por mil habitantes inferior à média do estado, com 1,64 leitos/1000hab., enquanto este último apresenta relação de 1,97 para o ano de 2003.

Causas Externas é a segunda causa de mortes em geral, sendo a primeira entre as pessoas de 10 a 29 anos. Tem uma taxa de envelhecimento, em 2006, de 16,07 contra 40,51 do estado. Sua população é jovem, com taxa de população com menos de 15 anos de 30,25, contra uma média estadual de 24,20. Sua mortalidade na população de 15 a 34 anos é de 156,28; superior à média do estado que é de 136,36.

No ano de 2002 foi apontada na grande imprensa como a cidade mais violenta do estado de São Paulo; Apesar da adoção de várias políticas públicas para o enfrentamento do problema, incluindo-se a edição da "Lei seca", com 
redução dos indicadores no ano seguinte, é novamente em 2004 citada na grande imprensa como a mais violenta do Estado de São Paulo.

O número absoluto de homicídios tem diminuído no período de 2000 a 2005. Foram 98 óbitos por esta causa básica em 2000; em 2001 este número aumentou, passando para 124 assassinatos; em 2004 apresentou queda expressiva com 65 casos, com número absoluto em 2005 de 49.

Apesar de não ser homicídios o único fator levado em conta ao se analisar a violência de uma cidade, destacamos o número de homicídios, por ser este o evento mais dramático ligado ao tema.

\section{Objetivos}

\subsection{Objetivo Geral}

Conhecer as idéias que permeiam a compreensão de violência no município de Itapecerica da Serra e discutir implicações na elaboração de políticas públicas para seu enfrentamento.

\subsection{Objetivos Específicos}

2.2.1. Investigar os óbitos por homicídio em Itapecerica da Serra - SP no ano de 2002.

2.2.2 Conhecer as representações sociais da violência entre a população de Itapecerica da Serra.

2.2.3 Identificar estratégias que a comunidade utiliza para lidar com a violência urbana e suas conseqüências. 
2.2.4 Contribuir para a elaboração de políticas públicas que visem o enfrentamento do problema, em especial nas ações de saúde.

\section{Metodologia}

Optamos por utilizar metodologia qualitativa, não como contraposição à abordagens quantitativas, mas sim como o mais adequado ao aprofundamento deste tema.

A natureza do problema a ser investigado com suas múltiplas facetas leva à necessidade de utilização de várias formas de aproximação.

\subsection{Revisão Bibliográfica}

A revisão bibliográfica foi realizada buscando-se levantar os diversos saberes que contribuem para o entendimento do problema como as ciências sociais, psicologia social, antropologia, criminalística, geografia e claro, saúde pública. A minha formação de médica sanitarista faz com que esta seja a área de maior apoio a este trabalho. Entretanto o tema exige uma aproximação destas outras áreas de conhecimento que permitem construir o referencial teórico que embasa esta pesquisa.

3.2 Identificação dos casos de homicídios do município de Itapecerica da Serra no ano de 2002.

Por ser o homicídio um evento indiscutivelmente violento, vamos utilizá-lo como evento sentinela. O município de Itapecerica da Serra é habilitado no Sistema Único de Saúde (SUS) como de gestão plena do sistema frente à NOB96; 
esta forma de habilitação de gestão implica em ter o município uma unidade de avaliação e controle que trabalhe com sistemas de informação.

Um destes sistemas é o SIM (Sistema de Informação de Mortalidade) onde são incluídos todos os óbitos ocorridos no município, independente do local de residência. Assim é que os casos ocorridos em serviços de saúde, vias públicas e outros são digitados pelo núcleo de informações da Secretaria Municipal de Saúde.

Os óbitos por causas externas são levados ao Instituto Médico Legal (IML) de Taboão da Serra, referência para Itapecerica da Serra, que envia à este serviço cópia das declarações de óbito emitidas de residentes no município. Levantamos as Declarações de Óbito (DO) encaminhadas pelo IML e destas separamos as que já vêm anotadas como homicídio e as que sugerem ser esta a causa. Desta forma, aqueles casos que têm referência a ser causa externa, não determinando se por homicídio ou não também foram levantados.

Estes óbitos foram separados entre residentes e não residentes no município. Para estudarmos aqueles em que não está anotado ser homicídio e os de não residentes foi necessário lançar mão de outra fonte primária de dados que é o boletim de ocorrência (BO) elaborado pelas delegacias de polícia do município.

A utilização deste recurso nos permitiu excluir todos por outras causas que não os de homicídio doloso. Os decorrentes de acidentes de trânsito, atropelamentos, suicídios não são o enfoque deste trabalho.

O boletim de ocorrência também nos permite um olhar mais profundo sobre os casos de não residentes. O município em questão possui dois pronto-socorros e um hospital geral. Muitos casos são digitados no sistema de informação municipal por ser, o local de ocorrência, um destes serviços de saúde. Limpamos 
este banco de dados utilizando apenas os casos em que o evento violento, que deu origem ao óbito tenha ocorrido no município.

A partir do cruzamento das informações contidas nas declarações de óbito e boletins de ocorrência, selecionamos para fins deste estudo de caso, aqueles cujo fato desencadeante do óbito tenha ocorrido em Itapecerica da Serra, sejam residente ou não.

Esta opção nos permite a visualização de um "mapa da violência" tanto por residência quanto por ocorrência, importante para os objetivos deste trabalho, nos servindo de ponto de partida para a investigação das representações sociais.

Foi possível também conhecermos a ocorrência deste evento em relação a diversas variáveis como sexo, idade, dia da semana, horário, causa.

Não dispomos de indicadores construídos e aceitos para trabalhar mortes violentas por local de ocorrência; vários pesquisadores entretanto vêm trabalhando na sua construção.

\subsection{Utilização do Discurso Do Sujeito Coletivo para a obtenção das} representações sociais

A opção pela metodologia qualitativa se impõe pela natureza do problema a ser estudado, permitindo o resgate dos significados deste grupo social. Desejamos saber o que pensam os atores sociais acerca da violência. Sabe-se que os pensamentos se dão sob formas discursivas. Estimular que as pessoas falem, discursem sobre o tema nos permite captar um material rico, vivo, capaz de fornecer dados importantes que reconstruam o pensamento coletivo. 
O Discurso do Sujeito Coletivo (DSC) é um procedimento metodológico que consiste em uma forma de representar o pensamento de uma coletividade através de discursos-síntese reconstruídos a partir de discursos individuais e agrupados por seus conteúdos de sentidos semelhantes. É uma soma qualitativa que expressa o pensamento do grupo estudado. É uma forma de apresentação de resultados de pesquisa qualitativa mais viva e direta já que o discurso é o modo como os indivíduos reais pensam (LÈFEVRE F., LĖFEVRE,A 2003)

Os depoimentos foram recolhidos sob a forma de entrevistas com questões abertas, gravadas em meio magnético, posteriormente transcritas literalmente. .A análise será feita com a utilização de três figuras metodológicas que compõem o DSC:

1) Expressões-chave (EC): São transcrições literais dos depoimentos, limpos dos vícios de linguagem e repetições de forma a recuperarmos a sua essência. Esta literalidade do depoimento é uma prova-discursivo-empírica, já que pode ser resgatada na entrevista original. É com as EC que se constroem os DSC.

2) Idéia Central (IC): Permite traduzir o essencial do discurso. É a sua síntese e a descrição de seu sentido. Um discurso pode ter mais de uma idéia central e cada uma deve ser estudada cuidadosamente.

4) Discurso do Sujeito Coletivo (DSC):A construção do DSC leva em conta princípios de coerência, posicionamento próprio.Construídos com as expressõeschave, estas devem ser organizadas levando-se em conta suas diferenças/antagonismos e complementaridade. Discursos com idéias contraditórias devem ser apresentados em separado. Aqueles que não apresentam idéias divergentes podem ser agrupados de forma complementar, podendo ser separados quando se deseja realçar pontos considerados relevantes. Este "discurso-síntese" expressa a fala do social ou o pensamento coletivo, apesar de expresso na primeira pessoa do singular, reconstruídos pelo pesquisador pela 
utilização de procedimentos explícitos, transparentes e padronizados próprios do rigor científico.

\subsection{Escolha dos sujeitos}

Dada a intenção de reconstruir a multiplicidade dos discursos existentes no campo social estudado, a seleção dos sujeitos deve levar em conta a quantidade, variabilidade e qualidade dos sujeitos a serem entrevistados, em termos da possibilidade de fornecerem dados ricos, interessantes e suficientes para compor e reconstruir o Discurso do Sujeito Coletivo. (LĖFEVRE, LÈFEVRE, E TEIXEIRA, 2000).

Neste estudo a quantidade não é uma variável crítica. Os discursos interferem mais que as pessoas. A variabilidade sim, é crítica. Trabalharemos com amostragem intencional.

Adotamos o homicídio como evento sentinela por ser, como nos diz MINAYO (1994,), a expressão máxima da exacerbação dos conflitos das relações interpessoais.

Optamos por abordar o problema a partir da escuta de diferentes ângulos, fazendo esta amostra representativa não pela quantidade dos entrevistados, mas pela sua variabilidade na composição do tecido social.

Inicialmente pensamos em trabalhar com quatro grupos a serem entrevistados; o primeiro constitui-se de parentes de vítimas de homicídio, ocorridos no ano de 2002, residentes no mesmo endereço da vítima, no município de Itapecerica da Serra. O segundo grupo constitui-se de pessoas que não sofreram homicídio na família, mas residem no mesmo bairro daqueles que foram vitimados; o terceiro grupo é composto pelos chamados formadores de opinião ou 
informantes-chave: pessoas com legitimidade institucional e/ou reconhecimento dentro de suas comunidades como líderes religiosos ( padre, pastor...), líderes políticos (prefeito, vereadores, deputados...), autoridades ( secretários municipais, delegado, comandante da polícia militar...), líderes comunitários como conselheiros de saúde (que neste município são eleitos por voto direto em seus bairros), membros das associações de moradores, de movimentos populares, e outros.Um quarto grupo a ser estudado é composto por pessoas envolvidas diretamente com o tema, pelo recorte da delinqüência, em atividade e em liberdade, aquém denominamos de protagonistas da violência.

A realização do pré-teste fez com que desistíssemos do segundo grupo que havia sido pensado, o de moradores do mesmo bairro, que não foram alvo direto de violência, pela dificuldade de acesso e de aceitação dos mesmos em participar da entrevista.

Optamos por substituir este grupo por um segmento social que não havia sido pensado anteriormente que é o de profissionais de saúde. Decidimos formar este grupo com profissionais que atuassem em serviço de urgência/ emergência do município, da região que concentra grande número de casos de homicídio, e com atuação em diversas etapas da assistência..

A inclusão deste grupo nos parece ser apropriada por terem uma aproximação com o tema de outro ângulo, que é o do atendimento às vítimas da violência.

Foi solicitada a autorização para a gravação da entrevista através do termo de consentimento esclarecido onde explicamos do que trata a pesquisa, aspectos éticos, garantia do sigilo e anonimato, além de colocá-los à vontade para participar ou não da entrevista. 
O quarto grupo, por sua natureza, foi formado pelas pessoas a que tivemos acesso. Para estes, o termo de consentimento esclarecido será feito de forma verbal, cumprindo-se todas as etapas realizadas para os demais grupos.

Optamos por trabalhar com histórias contadas aos entrevistados, que se assemelham a manchetes de jornal, seguidas de algumas perguntas.

\subsection{Apresentação dos Entrevistados}

Foram vinte e cinco entrevistados, divididos em quatro grupos conforme se segue:

Grupo I. Parentes de vítimas de homicídio.

Ao elaborarmos este projeto de pesquisa acreditávamos que este seria um grupo de fácil acesso, dado dispormos das declarações de óbito com o endereço das vítimas de homicídio.

Esta premissa mostrou-se equivocada. Foram cerca de 85 visitas aos endereços disponíveis, com um aproveitamento de apenas oito entrevistas, visto que nas outras 77 não encontramos as pessoas em casa.

Constatamos que grande parte dos familiares havia mudado de endereço, não constando aos vizinhos seu novo paradeiro, ou havendo entre eles o compromisso tácito de não informar o novo endereço.

A experiência de autores como a Profa. Mello Jorge demonstra esta grande mobilidade de grupos familiares submetidos a situações de violência. Foram oito as entrevistas realizadas neste grupo. 
Grupo I - Parentes de vítimas de violência

\begin{tabular}{|c|c|c|c|c|c|c|c|}
\hline \multirow[b]{2}{*}{ Entrevistado } & \multirow[b]{2}{*}{ Sexo } & \multirow[b]{2}{*}{ Idade } & \multirow[b]{2}{*}{ Cor } & \multirow[b]{2}{*}{ Parentesco } & \multicolumn{3}{|c|}{ Renda em } \\
\hline & & & & & Profissão & $\mathrm{R} \$$ & Escolaridade \\
\hline \multirow[t]{2}{*}{ vfamiliar01 } & Feminino & 66 & branca & mãe & Comerciante & 2000 & $1^{\circ}$ grau completo \\
\hline & & & & & & & $1^{\circ} \mathrm{grau}$ \\
\hline \multirow[t]{2}{*}{ vfamiliar02 } & Feminino & 52 & parda & mãe & Do lar & 240 & incompleto \\
\hline & & & & & & & $1^{\circ} \mathrm{grau}$ \\
\hline \multirow[t]{2}{*}{ vfamiliar03 } & Feminino & 54 & branca & mãe & Costureira & 600 & incompleto \\
\hline & & & & & & & $1^{\circ} \mathrm{grau}$ \\
\hline \multirow[t]{2}{*}{ vfamiliar04 } & Feminino & 33 & branca & esposa & Do lar & 500 & incompleto \\
\hline & & & & & Aux. & & $2^{\circ}$ grau \\
\hline \multirow[t]{2}{*}{ vfamiliar05 } & Feminino & 39 & branca & irmã & Cozinha & 240 & incompleto \\
\hline & & & & & & & $1^{\circ} \mathrm{grau}$ \\
\hline \multirow[t]{2}{*}{ vfamiliar06 } & Masculino & 48 & branca & tio & Comerciante & 800 & incompleto \\
\hline & & & & & & & $1^{\circ}$ grau \\
\hline \multirow[t]{2}{*}{ vfamiliar07 } & Feminino & 52 & parda & mãe & Do lar & 240 & incompleto \\
\hline & & & & & & & $1^{\circ} \mathrm{grau}$ \\
\hline vfamiliar08 & Feminino & 32 & branca & irmã & Do lar & 240 & incompleto \\
\hline
\end{tabular}

\section{Grupo II - Formadores de Opinião}

Este grupo foi composto de seis pessoas que sabidamente representam lideranças em suas comunidades.

\section{Grupo II - Formadores de Opinião}

\begin{tabular}{|c|c|c|c|c|c|c|}
\hline Entrevistado & Sexo & Idade & Cor & Profissão & Renda em R\$ & Escolaridade \\
\hline vfopinião01 & Masculino & 41 & Parda & Professor & 1.200 & Superior \\
\hline & & & & líder & & $1^{\circ} \mathrm{grau}$ \\
\hline vfopinião02 & Feminino & 56 & Parda & comunitária & 800 & incompleto \\
\hline vfopinião03 & Masculino & 57 & Branca & Delegado & 7000 & Superior \\
\hline vfopinião04 & Masculino & 32 & Branca & Padre & 560 & Superior \\
\hline vfopinião05 & Masculino & 41 & Branca & Prefeito & 7500 & Superior \\
\hline vfopinião06 & Feminino & 38 & Preta & Professora & 1800 & Superior \\
\hline
\end{tabular}


Grupo III - Profissionais de Saúde

Este grupo foi formado por profissionais que atuam no Pronto Socorro do Jardim Jacira, localizado em região reconhecida como das mais violentas do município, e para onde acorrem pessoas de outros municípios como Embu-Guaçu e dos bairros da Zona Sul do município de São Paulo, como o Jardim Calu, Jardim Capela, Vila Guiomar, Jardim Ângela e outros.

Grupo III - Profissionais de Saúde

\begin{tabular}{|c|c|c|c|c|c|c|}
\hline \multirow[b]{2}{*}{ Entrevistado } & \multirow[b]{2}{*}{ Sexo } & \multirow[b]{2}{*}{ Idade } & \multirow[b]{2}{*}{ Cor } & \multicolumn{3}{|c|}{ Renda em } \\
\hline & & & & Profissão & $\mathrm{R} \$$ & Escolaridade \\
\hline vprofsaude01 & Masculino & 39 & Parda & $\begin{array}{l}\text { Mot. Ambulância } \\
\text { Aux. }\end{array}$ & 1300 & $\begin{array}{c}2^{\circ} \text { grau } \\
\text { completo } \\
2^{\circ} \text { grau }\end{array}$ \\
\hline vprofsaude 02 & Masculino & 36 & Parda & $\begin{array}{c}\text { Enfermagem } \\
\text { Téc. }\end{array}$ & 800 & $\begin{array}{l}\text { completo } \\
2^{\circ} \text { grau }\end{array}$ \\
\hline vprofsaude03 & Feminino & 42 & Parda & $\begin{array}{c}\text { Enfermagem } \\
\text { Téc. }\end{array}$ & 1500 & $\begin{array}{l}\text { completo } \\
2^{\circ} \text { grau }\end{array}$ \\
\hline vprofsaude 04 & Feminino & 45 & Preta & Enfermagem & 1500 & completo \\
\hline vprofsaude05 & Masculino & 56 & Branca & Médico & 8000 & Superior \\
\hline vprofsaude06 & Feminino & 62 & Preta & Enfermeira & 4000 & Superior \\
\hline
\end{tabular}

Grupo IV - Protagonistas da violência

Neste grupo foram incluídas pessoas ligadas ao tema da violência por seu envolvimento na criminalidade. Na tabela abaixo serão apresentadas as profissões declaradas pelos entrevistados. Todos, no período em que as entrevistas foram realizadas, estavam em atividade, em liberdade e, por sugestão do primeiro 
entrevistado, atuavam em diferentes áreas como tráfico de drogas, assalto a banco, homicídio, assalto a mão armada.

Grupo IV - Protagonistas da Violência

\begin{tabular}{|c|c|c|c|c|c|c|}
\hline \multirow[b]{2}{*}{ Entrevistado } & \multirow[b]{2}{*}{ Sexo } & \multirow[b]{2}{*}{ Idade } & \multirow[b]{2}{*}{ Cor } & \multicolumn{3}{|c|}{ Renda em } \\
\hline & & & & Profissão & $\mathrm{R} \$$ & Escolaridade \\
\hline vprotagonista01 & Masculino & 32 & Preta & Comerciante & 3000 & $\begin{array}{c}2^{\circ} \text { grau completo } \\
1^{\circ} \mathrm{grau}\end{array}$ \\
\hline vprotagonista02 & Masculino & 20 & Parda & Aj. Geral & sem renda & $\begin{array}{c}\text { incompleto } \\
1^{\circ} \mathrm{grau}\end{array}$ \\
\hline vprotagonista03 & Masculino & 21 & Branca & Pintor & 800 & $\begin{array}{c}\text { incompleto } \\
1^{\circ} \mathrm{grau}\end{array}$ \\
\hline vprotagonista04 & Masculino & 37 & Parda & Comerciante & 10000 & $\begin{array}{c}\text { incompleto } \\
1^{\circ} \mathrm{grau}\end{array}$ \\
\hline vprotagonista05 & Masculino & 37 & Branca & Desempregado & 800 & incompleto \\
\hline
\end{tabular}

\subsection{Coleta e Transcrição dos Dados}

A obtenção dos dados foi feita mediante entrevistas semi-estruturadas cujo roteiro busca a objetividade e não a emissão de juízo de valor. Após a aplicação do pré-teste, observamos questões que não trouxeram qualquer contribuição aos objetivos deste estudo, além de tornar a entrevista longa e cansativa para os entrevistados. Estas questões foram excluídas.

Todas as situações descritas são de violência. São apresentadas de forma a trazer ao entrevistado o pensar sobre o tema da violência sob diversos aspectos, e estimulá-los a falar sobre isso. A seguir apresentamos o roteiro da entrevista:

1) Trabalhador voltando para casa passa na frente de um bar onde está acontecendo uma briga. Ouve-se um tiro e o homem cai morto por uma bala perdida. Fale sobre isso. 
2) Uma estudante, voltando da escola é atacada por um indivíduo que arrasta ela para o mato e estupra. Fale sobre isso.

3) Num bairro tem uma briga de dois grupos pelo domínio da área. Gente de um grupo mata pessoas da outra turma. Fale sobre isso.

4) Uma criança é trazida ao Pronto Socorro (PS) com o braço quebrado e estória de ter caído da escada. Depois de um mês, volta ao PS com manchas roxas pelo corpo. Fale sobre isso.

5) Comerciantes, cansados de serem assaltados, contratam "seguranças particulares". Estes matam uns rapazes negros, apontados como sendo os assaltantes. Fale sobre isso.

6) Como você acha que os serviços de saúde poderiam contribuir para a redução da violência?

7) Você gostaria de falar mais alguma coisa sobre a violência? Fique à vontade para fazer os comentários que desejar.

As entrevistas foram realizadas pela pesquisadora em sua totalidade. A entrevistadora foi acompanhada, no Jardim Jacira por um auxiliar de enfermagem nascido e criado no bairro, como forma de facilitar o acesso aos entrevistados, em especial os do grupo IV. As entrevistas realizadas no Parque Paraíso foram acompanhadas por um agente comunitário de saúde também nascido e criado no bairro. Estes acompanhantes atuaram como facilitadores para as entrevistas, sem contudo participar das mesmas.

As entrevistas foram gravadas, sendo as perguntas sempre as mesmas para os quatro grupos. As fitas gravadas foram transcritas literalmente, mantendose as expressões idiomáticas utilizadas, pausas, interjeições. 


\subsection{Tabulação dos Dados e Organização dos Discursos}

Para a tabulação dos dados foi utilizado o software Qualiquant desenvolvido por LĖFEVRE E LĖFEVRE na Faculdade de Saúde Pública. Foram seguidos os passos metodológicos recomendados para a construção dos DSC:

Primeiro passo: Leitura das respostas a cada pergunta, de cada entrevista em particular, identificando as expressões chave que serão copiadas no IAD1 (Instrumento de Análise de Discurso 1)

Segundo passo: Identificar e sublinhar em cada resposta as expressões chave das idéias centrais.

Terceiro passo: Identificar as idéias centrais, colocando-as nas caselas correspondentes.

Quarto passo: Identificar e agrupar as idéias centrais de mesmo sentido ou com sentidos complementares identificando cada grupamento com letras.

Quinto passo: Denominar cada um dos grupamentos.

Sexto passo: Através do uso do IAD2 (Instrumento de Análise de Discurso 2), constrói-se um DSC para cada grupamento identificado no passo anterior.

Os resultados serão apresentados em quadros síntese, compostos pelas idéias centrais e discursos correspondentes, explicitando que sujeitos contribuíram para a composição de cada DSC. 


\section{Resultados}

\section{1 Óbitos por homicídio em Itapecerica da Serra no ano de 2002}

Foram levantados os homicídios dolosos ocorridos em Itapecerica da Serra no ano de 2002 a partir de duas fontes primárias distintas: A Declaração de Óbito (DO) e Boletim de Ocorrência (BO). A utilização destas fontes distintas permite a obtenção de dados mais completos, em especial quanto ao local de ocorrência da circunstância que levou ao óbito.

Foram estudadas algumas variáveis como sexo, idade, cor, estado civil, escolaridade, diagnóstico pela CID-10 (Classificação Internacional de Doenças Décima revisão), local de residência e de ocorrência.

Detivemo-nos nos óbitos de residentes no município, independente do local de ocorrência, e também nos ocorridos no município de Itapecerica da Serra, mesmo que de não residentes.

Excluímos os óbitos ocorridos em serviços de saúde, cujo local de residência era ignorado.

. Esta exclusão deve-se ao fato de ser esta cidade vizinha à região sul da cidade de São Paulo, que à época deste levantamento era desprovida de serviços de urgência mais próximos.

A Fundação SEADE registra, para 0 ano de 2002, a ocorrência de 119 homicídios de residentes em Itapecerica da Serra, o que resulta em um coeficiente de 84,05 casos por 100.000 habitantes. Destes, estudamos 92 óbitos, em que foi possível levantar as declarações de óbito no Núcleo de Informação da Secretaria Municipal de Saúde (NIAC), e boletins de ocorrência na delegacia local. 
Tab.1 Óbitos por homicídio, ocorridos em Itapecerica da Serra, no ano de 2002, por sexo.

$\begin{array}{ccc}\text { Sexo } & \text { Número } & \text { Percentual } \\ \text { Masculino } & 86 & 93,5 \\ \text { Feminino } & 6 & 6,5 \\ \text { Total } & 92 & 100\end{array}$

Fonte: NIAC - Secretaria Municipal de Saúde de Itapecerica da Serra

Observa-se a esmagadora ocorrência por homicídios no sexo masculino, fator este que é bem retratado na pirâmide populacional desta cidade.

Tab. 2 Obitos por homicídios na cidade de Itapecerica da Serra por faixa etária, no ano de 2002

$\begin{array}{ccc}\text { Idade em anos } & \text { Número } & \text { Percentual } \\ 0 \text { a } 15 & 1 & 1,1 \\ 16 \text { a } 30 & 60 & 65,2 \\ 31 \text { a } 45 & 19 & 20,7 \\ 46 \text { e mais } & 6 & 6,5 \\ \text { Ignorado } & 6 & 6,5 \\ \text { Total } & 92 & 100\end{array}$

Fonte: NIAC - SMS Itap. Da Serra e Delegacia de Polícia local

Adolescentes e adultos jovens são os mais atingidos pela violência, em sua expressão de maior tragicidade. 


Tab.3 Obitos por homicídio ocorridos em Itapecerica da Serra por escolaridade em anos de estudo,
no ano de 2002.
\[ \begin{array}{ccc}\text { Escolaridade em anos de estudo } & \text { Número } & \text { Percentual } \\ \text { Nenhum } & 2 & 2,2 \\ 1 \text { a } 3 & 22 & 23,9 \\ 4 \text { a } 7 & 27 & 29,3 \\ 8 \text { a } 11 & 12 & 13 \\ 12 \text { e mais } & 0 & 0 \\ \text { Ignorado } & 29 & 31,5 \\ \text { Total } & 92 & 100\end{array} \]

Fonte: NIAC - SMS Itap. Da Serra e Delegacia Local

Estes dados reforçam a baixa escolaridade que predomina em vítimas de homicídios. $55,4 \%$ das vítimas de homicídio tinham até sete anos de estudo. $O$ índice de $31,5 \%$ de vítimas com escolaridade ignorada, reflete o grande número de corpos encontrados, em locais ermos, conhecidos como de "desova", de difícil identificação.

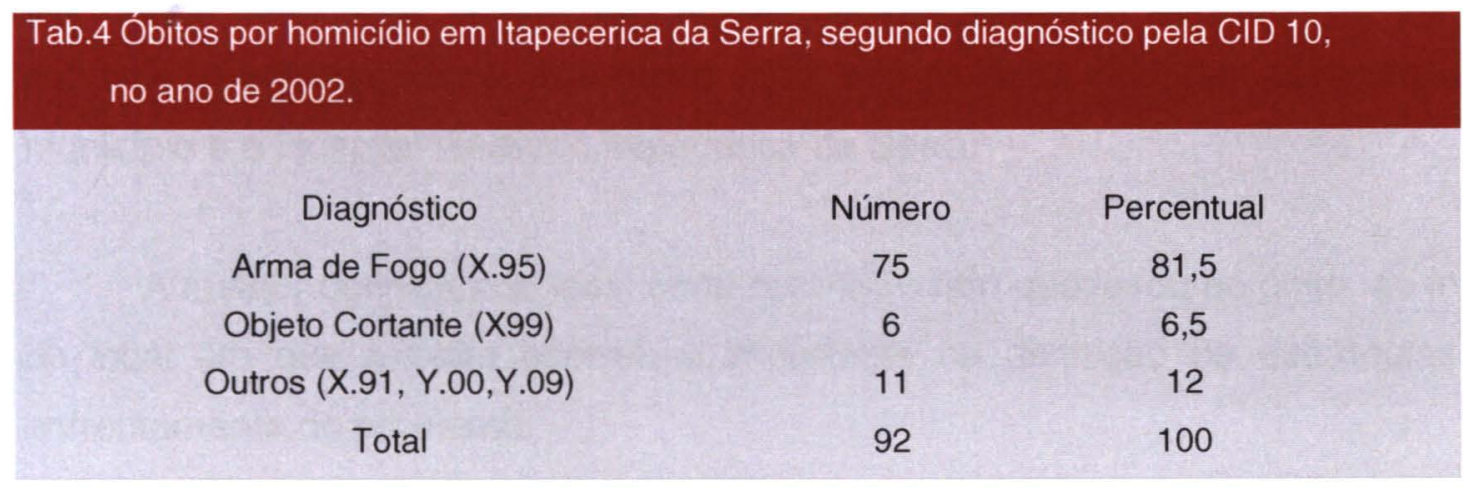

Fonte: NIAC - SMS Itap. Serra e Delegacia local

Arma de fogo é o principal instrumento utilizado na perpetração da violência. Apenas $18,5 \%$ dos casos ocorridos na cidade de Itapecerica da Serra no período estudado, o foram por outros meios nos quais se destaca isoladamente objetos cortantes, que observamos no decorrer da pesquisa, apesar de não ser 
objeto de estudo mais detalhado, ser o instrumento mais utilizado quando a vítima é do sexo feminino.

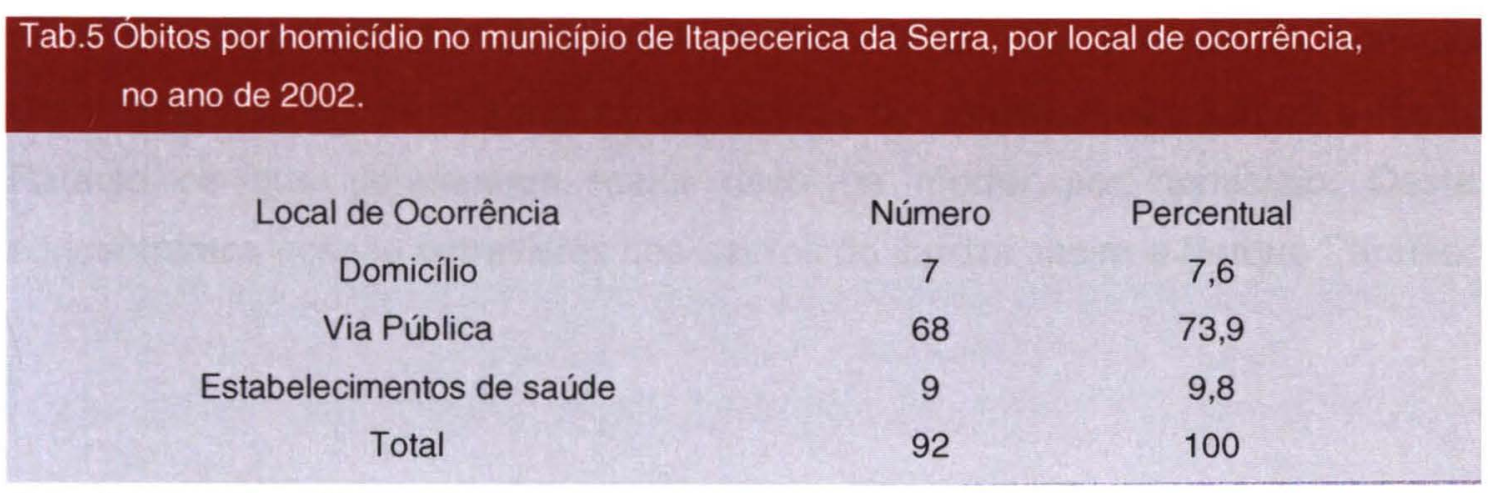

Fonte: Levantamento de BO na Delegacia local

A via pública é o local mais citado nos boletins de ocorrência registrados na delegacia de polícia de Itapecerica da Serra, como o de ocorrência dos óbitos. Nesta classificação incluem-se bares, terrenos baldios, praças, ruas e outros. Estabelecimentos de saúde aparecem com nove casos, nos quais não foi possível identificar, no momento do registro do boletim de ocorrência, o local em que ocorreu o fato que levou ao óbito, tendo a vítima falecido dentro do estabelecimento de saúde, que neste caso, são as duas unidades socorristas do município e o Hospital Geral de Itapecerica da Serra.

A melhor definição do local onde ocorreu o fato que levou ao óbito, ao invés do local em que o óbito ocorreu é importante na definição de estratégias de enfrentamento do problema.

Estes dados da pesquisa nos permitem desenhar o perfil da vítima de homicídio: Homem (93,5\%), jovem com idade entre 16 e 30 anos $(65,2 \%)$, solteiro $(68,5 \%)$, com baixa escolaridade $(55,4 \%)$, atingido por arma de fogo $(81,5 \%)$, em via pública $(73,9 \%)$. 
Ao colocarmos estas mortes no mapa da cidade, verificamos diferenças entre local de residência e de ocorrência.

O mapa que ilustra o local de residência das vítimas de homicídio demonstram serem os moradores dos bairros do Jardim Jacira, Lagoa e Parque Paraíso os que apresentam maior risco de morrer por homicídio. Destes, concentramos nossas entrevistas nos bairros do Jardim Jacira e Parque Paraíso.

\section{ÓBITOS POR RESIDÊNCIA - ITAPECERICA DA SERRA - 2002}

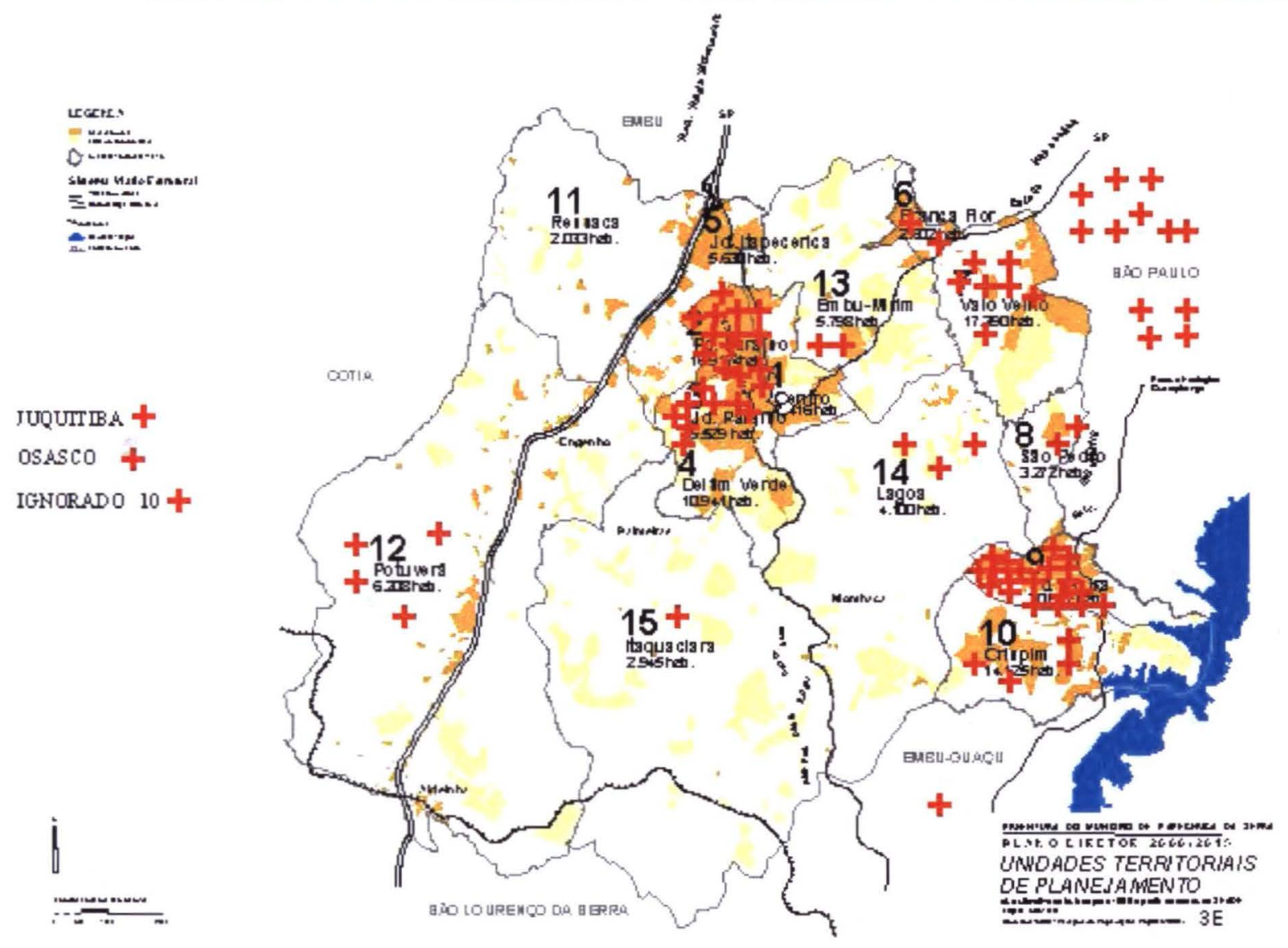


Ao estudarmos o endereço do local da ocorrência, quer seja a vítima residente ou não no município de Itapecerica da Serra, destacam-se os bairros do Valo Velho, Potuverá e Jardim Jacira, seguidos da Lagoa e Parque Paraíso.

\section{ÓBITOS POR OCORRÊNCIA - ITAPECERICA DA SERRA - 2002}

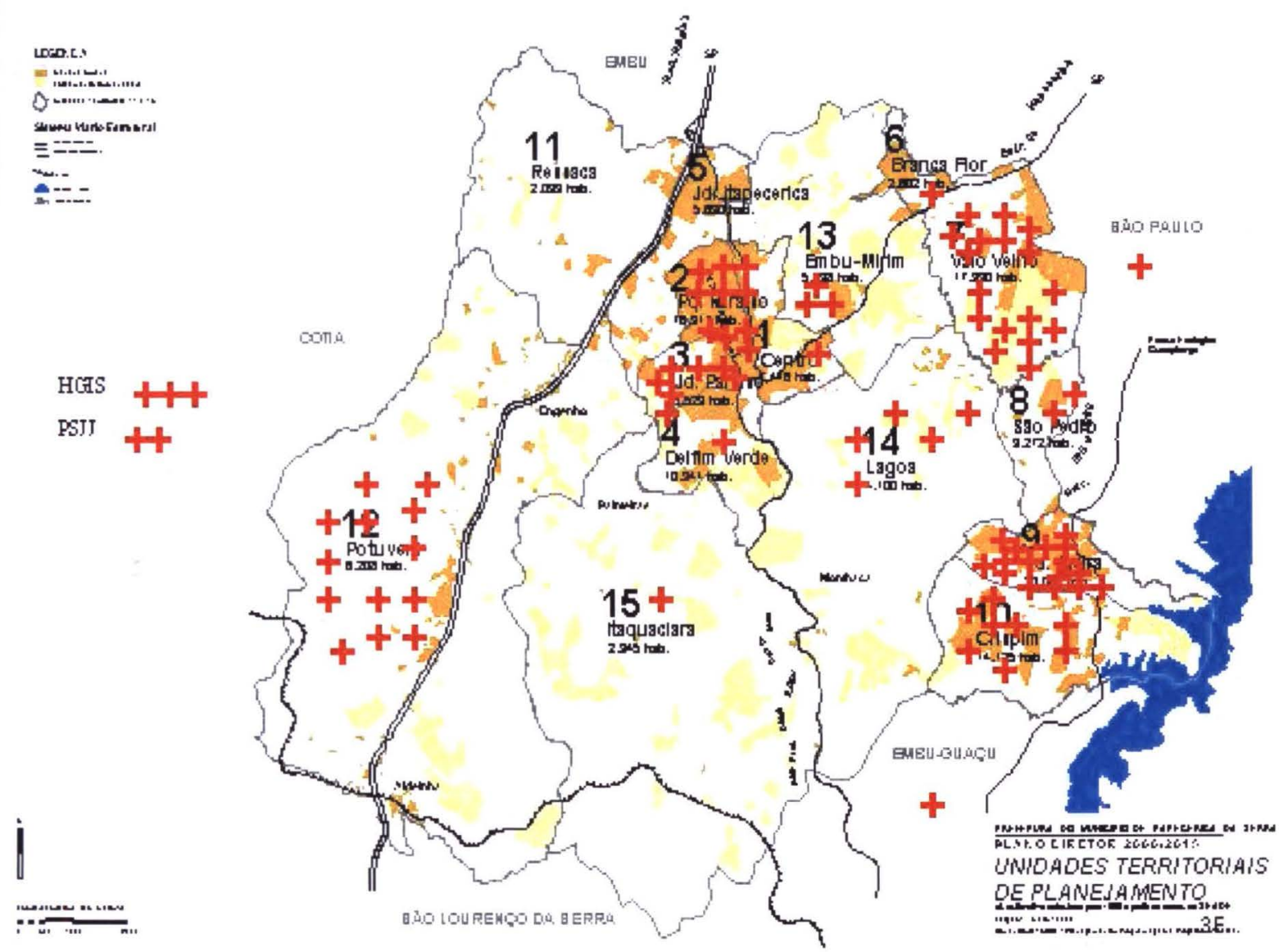

A realização da pesquisa de campo nos fez conhecer melhor onde e como vivem nossos entrevistados. Os grupos de familiares de vítimas e de protagonistas 
da violência foram formados basicamente por pessoas dos bairros do Jardim Jacira e Parque Paraíso, reconhecidos no município como os mais violentos. Os formadores de opinião tiveram distribuição semelhante, excluindo-se o prefeito e o delegado que não residem nestas áreas. Para os profissionais de saúde, optamos pelos que atuam no pronto socorro do Jardim Jacira, por lidarem com situações de violência mais cotidianamente.

\subsection{Representações Sociais da Violência em Itapecerica da Serra no} ano de $2003-2004$

As histórias apresentadas no formato de manchetes de jornal foram criadas com o objetivo de atuarem como disparadores temáticos, despertando no entrevistado o falar sobre o tema violência. Foram escolhidas situações que remetem a questões de preconceito racial, violência de gênero, violência familiar, contra a pessoa, poder paralelo. Apesar de abordarem aspectos diversos, todas têm como pano de fundo, situações de violência.

Os familiares de vítimas de violência foram, em sua grande maioria, mulheres, mães, irmãs e/ou esposa das vítimas. As mães em especial mostraramse muito emocionadas; relatavam que estas histórias traziam de volta a dor da perda sofrida. Em muitas entrevistas com as mães, tivemos que fazer uma pausa antes de prosseguirmos com as questões.

Os protagonistas da violência tinham o começo da entrevista muito difícil, com grande desconfiança, em especial pelo fato de ser a entrevista gravada. Após explicarmos a importância da gravação e, com a concordância dos mesmos, a entrevista era iniciada. Foi fundamental estar acompanhada de um membro da comunidade que atuou como facilitador e avalista de nossa presença no bairro e dos procedimentos metodológicos adotados. Após o término da entrevista, quando desligávamos o gravador, observávamos uma descontração, com a conversa 
adquirindo uma fluidez que, apesar de não se ater às histórias contadas, revelavam o cotidiano de suas atividades.

Optamos por apresentar inicialmente todos os discursos identificados para cada pergunta da entrevista.

Pensamos que outra abordagem possível é a identificação dos grandes temas que emergem dos discursos obtidos em cada pergunta.

Pudemos observar que no início de cada resposta os entrevistados procuravam se ater ao conteúdo da história contada. À medida em que falavam entretanto, abandonavam a pergunta original e discorriam sobre a violência em geral.

4.2.1. Primeira pergunta: Trabalhador voltando para casa passa na frente de um bar onde está acontecendo uma briga. Ouve-se um tiro e o homem cai morto por uma bala perdida. Fale sobre isso.

Categoria

Idéia Central

A

B

C

D

E

$\mathrm{F}$

G

$\mathrm{H}$

I

J
Consumo de Álcool e Drogas

Condições de vida social e urbana

Fácil acesso às armas

$\mathrm{O}$ acaso

Falta de segurança

Problemas de policiamento

Descaso das Instituições

Falta de convivência social

Não consegue identificar causa

Impunidade do menor 


\subsubsection{Categoria a - Explica a violência pelo consumo de álcool e drogas}

Acontece muito isso daí. Muito mesmo. Antigamente, se tinham as bebidas também, não tinha droga. Era muito pouco. Álcool, droga, a pessoa não tá nem aí. O pessoal está ali tomando uma cerveja, um vai usar uma droguinha. A pessoa quando tá no começo de tomar uma cerveja $e$ não usar droga é uma coisa, depois que usou e bebeu se transforma rapidinho, com uma coisinha de nada mesmo vai arrumar confusão, e se está armado (...) então acerta alguém que não tem nada a ver. Acontece mesmo; o problema da droga influencia muito forte, contribui para essa violência que termina sempre nesses quadros. Estou falando de uma forma geral, a bebida é uma droga também. Então eu acho que nós temos que ir para a rua, nós temos que conversar. Eu tinha muito medo de enfrentar, mas eu passei na pele. Talvez a morte do meu filho foi para me dar uma lição de moral. Eu trancava tudo. Eu continuo, eu tranco o portão, mas agora eu não tenho medo de chegar aqui na rua.

(vfamiliar01,vfopinião03,vprofsaúde01,vprofsaúde04)

\subsection{1..2 Categoria b - Explica a violência como conseqüência das condições de vida} social e urbana.

A partir do momento que passa em frente ao bar e leva um tiro, ele faz parte daquele contexto, ele não está passando ali acidentalmente. Ele tem uma referência com aquele local, portanto acho que ele é uma vítima da sociedade contemporânea. Que envolve tanto as pessoas que estavam lá, quanto este que estava passando no local. Isso é trágico, mas infelizmente acontece. Não só nos bares, também em frente às escolas. A criançada conta casos de tiro perdido. Isso acontece no bairro. Como também acontece de certas pessoas tirarem a vida dos outros sem motivo nenhum. Às vezes, em porta de bar, a pessoa entra bem e sai mal, sai violenta. Eu falo na periferia porque é onde eu mais convivo. Também pode acontecer em outros lugares, lógico, porque a violência em outros lugares é a mesma coisa. A periferia em si parece que gera uma violência já desde pequeno. Eu acho que é a miséria, a miséria dos pais que tentam dar o melhor, por mais pobre que sejam, procuram dar uma educação, procuram pôr o filho numa criação boa, só que às vezes sofrem a influência do lugar em que moram. E um caso como esse acontece todo o dia em quase todo barzinho e em quase todos os bairros. Acho que é tão complexo que para solucionar a gente não tem de imediato nenhuma resposta. Acho que é todo um trabalho bem prolongado, trabalhar a população, educação. Principalmente, porque se as pessoas fossem educadas para respeitar uma a vida das outras, elas nem andariam armadas, nem estariam dando tiros na rua, nada dessas coisas. Muito complexo, eu acho que a pobreza interfere nisso, e também o desemprego. Eu acho que tudo o que pode marginalizar o ser humano contribui 
para isso dai. Eu já quase presenciei um caso desse aqui perto, numa madrugada em um bar aqui próximo. Infelizmente essa região aqui é mais ou menos super quente. $E$ isso se deve principalmente ao meio. Do meio ambiente, da falta de educação, de não ter opções de lazer. $A$ familia sai e deixa os filhos praticamente sozinhos em casa e eles começam a se envolver com outras pessoas que dão o exemplo e acaba essa criança criando um meio propício para a violência. A nossa renda é mal dividida e isso vem há muitos anos, desde que o Brasil foi descoberto. Nós sabemos disso. E cabe a cada um de nós fazer um pouquinho.

(vfamiliar01, vfopinião05, vfopinião06, vprotagonista05,vprofsaúde01,vprofsaúde02, vprofsaúde04,vprofsaúde05, vprofsaúde06)

Este é um discurso formado por nove dos entrevistados, incluindo um protagonista da violência. A compreensão de que a forma como a sociedade contemporânea está organizada contribui para a violência não é privilégio de algum grupo em especial, mas permeia os quatro grupos estudados.

\subsection{1..3 Categoria c - Explica a violência pelo fácil acesso às armas}

Como é que eu vou falar sobre isso, meu Deus? O pessoal ultimamente está usando a arma por qualquer motivo. Por qualquer motivo eles tiram a vida. Antigamente não, antigamente 0 pessoal brigava com soco, hoje em dia é o revólver. Eu acho isso super errado, eu não aceito. $E$ uma coisa que poderia ser evitada, se existisse como falam muito, essa coisa de desarmamento, Se aquela pessoa que deu esse tiro não tivesse com uma arma, talvez não tivesse acontecido. Às vezes por causa de uma discussão boba, por causa de uma desavença qualquer, estão atirando à toa e às vezes acontece de tirar a vida de uma pessoa que não tem nada a ver.

(vfamiliar07, vfamiliar08,vfopinião02,vprofsaúde01)

\subsubsection{Categoria d - Explica a violência por estar no lugar errado na hora errada - 0} acaso.

Eu acho assim, que se a pessoa estivesse em casa não poderia acontecer. É uma violência muito grande, o coitado não tinha nada a ver com isso, mas às vezes o inocente paga pelo pecador. Foi passando no lugar errado, na hora errada. Eu acho que é isso. No caso dele foi um acidente. A pessoa hoje, ela saindo de casa, ela não sabe se volta, porque é bala perdida, é você estar no lugar errado, na hora errada. Tudo isso daí é violência. Acontece em todos os cantos, gente que toma tiro de bala perdida, está passando e não tem nada a ver com a história. Todo mundo está arriscado a morrer, pode ser eu ou você estar dentro de um carro, vem um tiro não sei de onde e acerta em você, em mim, na minha mãe, em qualquer pessoa, acho normal isso daí. Não é uma violência no modo de dizer assim, porque acho que ele passou no lugar errado, na 
hora errada, uma violência é quando o pessoal está no bar e acontece um tiroteio, o pessoal assassina e acontece duas ou três mortes; ai é uma violência, mas ele passou no lugar errado, na hora errada.

(vfamiliar02, vfamiliar03, vfamiliar04, vprotagonista01,vprotagonista02, vprotagonista04, vprofsaúde02)

\subsection{1..5 Categoria e - Explica a violência pela falta de segurança}

É problema de segurança. Eu acredito que se tivesse uma segurança melhor teria menos gente armado na rua, num bar que é um lugar público, para estar matando pessoas. Porque se tivesse uma segurança naquele local, pelo menos uma segurança, uma viatura, se tivesse pelo menos essa expectativa, alguém poderia fazer alguma coisa, de evitar que ele acontecesse. Bairro assim igual ao nosso, não passa quase polícia, mas devia. À noite, tarde da noite você não vê passar polícia aqui. Às vezes as coisas estão acontecendo quando a polícia passa, e eles não vêm. Eles param uma pessoa que não tem nada a ver, igual já pararam o meu filho aqui, querendo jogar a culpa num inocente e deixar o culpado ir embora. Tanto com ele como com outras pessoas. Eu só acho isso, falta de segurança.

(vfamiliar05,vprofsaúde03,vprofsaúde06)

\subsection{1..6 Categoria f - Explica a violência por problemas no policiamento.}

Eu acho que se a polícia agisse com efetivo maior e não houvesse corrupção da parte policial, não existiria essa arma que disparou e acabou acertando uma pessoa inocente. Porque a maioria das armas são fabricadas, e para se comprar, você tem um registro, e no fim, cai na mão do bandido, que nem documento tem. Isso é porque existe corrupção policial, porque senão esse cara não conseguiria nunca comprar uma arma e nem tampouco a munição. Porque um trabalhador, se eu quiser comprar uma arma, eu tenho muita dificuldade para adquirir essa arma. $E$, no entanto os maus elementos, os bandidos, andam sempre armados. A polícia pega a arma deles aqui e vende para outro lá na esquina, e que depois acaba retornando para a mão dele. Então eu acho isso, o problema maior é a corrupção policial. Por isso existe tudo isso aí. Se não houvesse corrupção policial, a arma era presa, o bandido era preso e evitava todos esses problemas. Moro aqui num local que tem muita criminalidade. Não conheço nenhum policial corrupto, também não é interesse meu, porque tem as autoridades para apurar isso. Se eu cometer um deslize, eu imagino que eles vêm em cima de mim então, se o policial comete, tem a autoridade superior a ele para ver isso aí e no entanto, ninguém se interessa. Ttem muito inocente na cadeia, enquanto os verdadeiros culpados estão na rua. Inocentes passam por coisas que não 
devia, humilhações, apanham, assinam coisas que não fez, Eu acho isso aí o cúmulo, eu acho que a polícia tem que investigar antes de pegar também as pessoas, prender e pôr a culpa nas pessoas. Porque na verdade o culpado às vezes está solto e a pessoa que não tem nada a ver vai presa.

(vfamiliar05,vfamiliar06)

\subsection{1..7 Categoria g - Explica a violência pelo descaso das instituições}

Acho uma sacanagem. É uma coisa que a justiça tinha que tomar providências. Mas as autoridades são corruptas, inclusive os legisladores, os que fazem as leis, porque se a gente trancar um padre que defende os direitos humanos, com toda sinceridade, dentro de um quarto, $e$ um deputado que defende os menores; dentro de um quarto desse daqui, junto com dois bandidinhos de 15 anos, 14 anos, cada um com uma arma na mão, deixar eles pelo menos 3 dias; se eles conseguissem sobreviver, aí tinha que dar parabéns para eles. Se os caras não arrancassem com o dedo, desculpa a força de expressão, o coração deles, para comer na hora da fome, ai tinha poder essas leis. Na minha opinião, todos que defendem bandidos, são bandidos. Porque eu sinto na pele a perda. Estou falando com sinceridade, me emociona de falar, e nenhum vagabundo desses que faz as leis para defender bandido, sentiu isso ai na pele, porque o dia que sentir, vão mudar de idéia. Só que infelizmente eles vivem rodeados de guardas, rodeados de câmeras, muros altos, andam de avião, helicóptero, carro blindado. E eu não, eu ando de pé, na rua, eu estou exposto ao perigo, só que eu não tenho poder para mudar nada, infelizmente é assim.

(vfamiliar06,vprotagonista03)

Em alguns momentos, o discurso de um familiar compõe com 0 de protagonista da violência $\circ$ que talvez possa ser explicado por compartilharem o viver em condições muito semelhantes tanto no que diz respeito a lugar de moradia, acesso a bens e consumo, lazer, estudo e outras condições do cotidiano.

\subsection{1..8 Categoria $h$ - Explica a violência pela falta de convivência social}

Aí entra $O$ aspecto da responsabilidade para com o outro. $O$ que você faz não tem incidência só na sua vida ou só naquele que está aí. Isto tem conseqüências às vezes distantes, tanto no tempo quanto no espaço para atingir quem estava desconexo daquela situação. Estava fora, mas também sofreu os efeitos de um ato de violência. Mas eu acho que nós estamos sendo covardes. Nós estamos botando as grades nas portas, fechando as nossas casas, enquanto nós 
teríamos que ir para a praça, para as ruas....Enquanto nos fechamos dentro de casa, lá fora as praças que poderiam ser para os nossos filhos, para os nossos netos, para os nossos amigos ficam para eles... ir para a praça comer uma pipoca, conversar, até escutar uma música, contar estória dos antigos, a gente sentar com os filhos, com os netos, e contar como foi a vida dos nossos pais, dos nossos avós, como que foi crescer, como é que aquela cidade se formou? Isso fechou. Se pôs uma comadre na sala (a televisão), uma dona princesa,e só escuta a dona princesa,e ela fala da violência, ai que horror. E isso, não dá. Na pobreza, na média, em todas as classes, todas.

(vfamiliar01)

Este discurso traz a questão do abandono de práticas antes existentes que propiciavam um maior convívio dentro das casas e de redes sociais informais como a vizinhança.

\subsection{1..9 Categoria $i$ - Explica não saber explicar a causa da violência}

Com certeza houve um ato de violência ali quando ele estava passando. Se ele passou perto de um bar e estava acontecendo um confronto corporal, houve tiro, então houve um confronto que com certeza, na minha visão é violência. Agora o motivo por que aconteceu aquela violência, aquele ato, aquela ação em si, não dá para identificar de imediato. Teria que ter mais informações para ver o motivo.

(vfopinião01)

\subsection{1..10 Categoria $j$ - Explica a violência pela impunidade do menor.}

Moleques com 12 anos, 10 anos, estão com arma na mão. Quem deu essa arma? Não foi ele quem fabricou. Essa arma veio da mão de alguém. Então o que eu penso é isso: teria que primeiro corrigir, esse negócio de dizer que menor de idade não pode ir para cadeia, isso aí é balela, isso aí é safadeza. Eu comecei a trabalhar com carteira registrada com menos de 13 anos. Eu cheguei aqui em São Paulo com menos de 13 anos. E, no entanto, nenhum dos meus colegas que começaram na minha época virou bandido, porque todos trabalhavam com carteira registrada. Se eu, ou qualquer um de nós, na época fosse pego fazendo qualquer coisa errada, a gente pagava. Primeiro os pais tinham pulso para corrigir, porque hoje um pai não pode corrigir um filho, se um pai dá um tapa no filho porque o filho errou, ai vem tantas coisas, Conselho Tutelar e mais não sei o que, que vem contra o pai, mas não procura saber o que o filho aprontou, entendeu? Então o pai perdeu o poder que tinha sobre o filho. Aí o que acontece? Lá fora autoridade também 
não corrige. Vai lá para a FEBEM para ensinar ele virar bandido. Porque quando ele vai para lá, ele vai como aprendiz, vai como estagiário e volta formado como bandido profissional. Aí sai na rua com 16 anos matando todo mundo que ele tem direito, que ele imagina que ele tem direito de matar. E, no entanto, no dia que ele é preso, ele mesmo fala, na cara da vítima, "eu sou de menor e não acontece nada comigo", e pronto.

(vfamiliar06) 
4.2.2 Segunda Pergunta - Uma estudante, voltando da escola é atacada por um individuo que arrasta ela para o mato e estupra. Fale sobre isso.

\begin{tabular}{|cl}
\hline Categoria & \multicolumn{1}{c}{ Idéia Central } \\
A & Doença mental \\
B & Medo \\
C & Condições sociais e urbanas \\
D & Falta de educação \\
E & Impunidade \\
F & Falta de policiamento e segurança \\
G & Falta de sentido \\
H & Sugere punições severas \\
I & Questão de gênero \\
J & Falta de interesse político \\
K & Falta de solidariedade
\end{tabular}

\subsubsection{Categoria a - Explica a violência enquanto doença mental}

No caso aí ele é um psicopata, não é normal não. Porque uma pessoa que violenta a outra, não é normal não. Um débil mental no caso. Porque você pegar uma mulher à força e ter uma relação com ela à força, não é normal. Nesse caso ele é um monstro, porque um homem que faz isso com uma mulher, é um monstro. Eu acho que nem um animal faz isso com outro animal. A gente poderia falar tantas coisas sobre esse ato. Pode ter acontecido por tantos motivos. A pessoa que atacou essa menina, poderia ter um distúrbio, na sua criação, ou até mesmo na mente, algum trauma de infância, sei lá, são tantos motivos que podem ter levado a atacar aquela pessoa. Uma pessoa dessa, ela não vai presa como uma criminosa, mas geralmente um ato desse pode até ser considerado como problemas psíquicos mesmo. Violência que já beira a psiquiatria, que é resultado de processos já complexos. Desvios do indivíduo de vários aspectos. Tem louco pra tudo; uns gostam de roubar, outros gostam de matar e outros gostam de estuprar, tem gente que 
tem maldade pra tudo na cabeça. Nenhum bandido gosta disso ai de estuprar uma aluna que esta vindo de um colégio.

(vfamiliar04, vfopinião01, vfopinião04, vprotagonista02, vprofsaúde01)

Este discurso é compartilhado pelos quatro grupos entrevistados. É situação apresentada que provoca grande emoção.

\subsubsection{Categoria b - Explica a violência pelo medo}

Uma pergunta que é tão difícil responder. É duro você ter sua filha, que vai para a escola e quando volta o cara faz isso. Ih, meu Deus, se fosse minha filha eu não sei o que faria não. $A$ pessoa hoje, sabe que sai, mas não sabe se volta mais. Não sabe se morre, não sabe se é estuprada, se vai ser assaltada. É muito triste. O mundo está perdido. Pensando bem, imagina 0 que pensa o pai e a mãe dessa menina, é duro. Sua filha vai para a escola, você espera ela chegar e não, vem um cara que sem mais nem menos pega sua filha, mata e estupra. É muito difícil. Eu só peço para Deus para não acontecer isso com a minha. Porque a minha, como estuda, eu tenho medo, eu tenho muito medo; enquanto ela não chega, se atrasar 10 minutos eu já estou apavorada. Fica passando bobagem na cabeça da gente. E é uma coisa que a sociedade deveria se preocupar. Eu fiquei uma pessoa medrosa. Antigamente eu não tinha muito medo de andar na rua, tarde que fosse. Hoje em dia eu fiquei medrosa, não sou mais aquela pessoa que saía e não tinha muito medo. Hoje em dia as meninas também procuram muito. As meninas de hoje em dia arrumam uns caras para namorar, vão para os lugares e voltam tarde. Aí que correm perigo. Tem sempre que andar acompanhada. O pai buscar, ou a mãe, ou irmão mais velho. Porque andar sozinho é mais perigoso. Faz umas duas semanas aconteceu isso na escola e estavam liberando um pouquinho mais cedo mediante esse problema. Inclusive, eu estava com medo, e fico andando com um estiletinho aí, porque qualquer coisa eu arranco o negócio. É cruel, você está aguardando uma pessoa e ela não volta, dá revolta, desespero, medo, trauma. E para que possa se recuperar daquilo é muito difícil.

(vfamiliar07,vfamiliar08, vfopinião06, vprofsaúde03)

\subsubsection{Categoria c - Explica a violência pelas condições sociais e urbanas}

Uma violência muito grande que deveria ser evitada, mas o mundo que a gente está atravessando, está muito difícil. O crime de estupro é, mesmo para os policiais, o mais revoltante porque além dele agredir a integridade física da pessoa, ele agride a honra, o estado psíquico. 
Causa danos às vezes irreversiveis e esta situação infelizmente é muito comum principalmente na periferia. Pessoas que moram em locais mais afastados na periferia, estas jovens estão mais sujeitas a isso que é considerado crime hediondo, e que ocorre freqüentemente, e envolve crianças e adolescentes, que não têm poder de reação frente a esta criminalidade. São as maiores vítimas da violência. Não sei se acontece nos bairros mais nobres, pode acontecer também, mas isso acontece muito na periferia. No bairro onde que eu moro já vi muitos casos sobre isso. As pessoas que moram na periferia, muitos, talvez $90 \%$ não tem nenhuma ideologia, nenhum estudo; eles já pensam que se o cara fez um negócio errado ele vai ter que pagar pelo erro que ele fez $e$ acaba acontecendo de, as pessoas que moram em redor, os vizinhos do bairro, cometerem outro crime que é acabar com a vida daquela pessoa que fez aquele ato, que cometeu aquele ato. Porque quem está na periferia é pobre de tudo, a gente sabe que ele não tem uma estrutura trabalhada ao longo da vida. É uma conseqüência do meio ambiente. É um produto do meio ambiente. É estupro, é assassinato. Esse estuprador talvez não tenha tido a oportunidade de estudar, de conseguir um emprego, talvez seja um filho abandonado, não teve o carinho dos pais e fica por ai perambulando, e o que dá na cabeça dele ele faz.

(vfamiliar03,vfopinião03,vfopinião05, vprofsaúde01,vprofsaúde02,vprofsaúde04, vprofsaúde05)

\subsubsection{Categoria d - Explica a violência pela falta de educação}

Eu acho que falta educação, mas educação mesmo. Eu acho que as pessoas não aprendem, não aprendem o valor da vida, o respeito pelo outro ser $e$ às vezes se descontrola por falta de educação também. Se tivesse educação sexual poderia não estar estuprando na rua. Mais um episódio de violência, de falta de educação. $A$ educação primordial que tem que vir desde a infância, que engloba tudo. Eu acho que até a educação religiosa também pega nisso daí.

(vprofsaúde04,vprofsaúde06)

\subsubsection{Categoria e - Explica a violência pela impunidade}

Eu acho que isso é uma violência muito grande e que tinha que ter uma lei para essas pessoas, não podia ficar impune não. Porque se tivesse uma lei no nosso País não tinha isso. Ninguém ia estuprar ninguém, ninguém ia fazer essas maldades que fazem. Não tem lei no nosso País. Eu acho que não tem lei. A lei não é válida, a lei só vale para os poderosos, porque para pobre não vale não. Tem a lei, mas não é usada. Não é aplicada. Tem impunidade. Se tivesse um sistema mais duro, uma punição maior para quem fosse pego. Esse negócio de bom 
comportamento, sai com não sei quanto tempo, isso é safadeza. O cara chega lá e vira mocinha lá dentro para ficar bom, quando sai na rua, sai matando do mesmo jeito, a mesma coisa.

(vfamiliar05, vfamiliar06)

\subsubsection{Categoria $f$ - Explica a violência pela falta de policiamento e segurança}

É preciso ter mais policiamento, mais segurança. Falam muito na televisão que tem guarda na escola, que tem isso e que tem aquilo e no final das contas a gente vê as coisas acontecerem a olhos nus, de dia, de noite, a qualquer horário e a gente não pode fazer nada. Tenta proteger pelo menos os filhos da gente. Não tem jeito. Pelo menos a gente tenta, faz o que pode. A gente não vê providências. Quando acontece isso, a polícia aparece aí umas duas semanas em volta da escola, no horário de aula, das 19 até as 23 horas. Mas uma semana depois, passou aquele bafafá, aquele problema, acabou. A gente não tem mais segurança, não tem muito que se fazer.

(vfamiliar08,vfopinião06)

\subsubsection{Categoria g - Explica a violência pela desigualdade}

A lei tem que valer para todos igual, não é só para os ricos não. Tem que valer para os pobres e pros ricos. É muita desigualdade. Eles são elite, então eles são diferentes da gente. Eles passam aqui com carro blindado; se acontecer uma bala perdida e pegar o carro deles, não acontece nada. Agora um coitado que anda a pé ou de bicicleta na rua aí, está exposto. E na realidade é quem é honesto. Porque esses safados aí são honestos até o dia em que assumem o poder. Depois que assume o poder, todo mundo muda de opinião, e isso é o mal.

(vfamiliar05, vfamiliar06)

\subsubsection{Categoria $h$ - Explica a violência pela falta de sentido}

Isso é muito triste. Eu nem sei falar, porque eu fico tão nervosa com essas coisas que eu nem sei falar. É algo sem noção, não tem sentido, não tem nem o que falar, fico até sem palavras de falar nisso.

(vfamiliar02,vprotagonista03)

\subsubsection{Categoria $i$ - sugere punições severas}

Ele tem que ser morto. Um cara desse não tem que ter piedade não. Tem que ser severa a punição dele. Isso dai é uma coisa muito triste que vagabundo não aceita, um crime que não tem 
onda, que não tem significado, porque esse artigo ai é o pior que tem, ou na rua ou na cadeia, cara que faz isso ai não é homem não, a sentença dele é a morte, não se espera nem a sociedade fazer, os próprios criminosos já matam quem faz isso. Uns caras desses num lugar que eu fiquei durante um bom tempo, sofrem. É discriminado por tudo e por todos.

(vprotagonista01,vprotagonista04,vprotagonista05)

Os protagonistas da violência compartilham a idéia de que este tipo de crime deve ser punido com muita severidade, inclusive com a morte. Apesar de causar muita revolta em todos os entrevistados, este discurso é manifestado apenas por este grupo.

\subsubsection{Categoria $j$ - Explica a violência pela questão de gênero}

Ah eu sou revoltada com isso; eu acho que a mulher na sociedade deveria ter um papel melhor, porque uma mulher estuprada ela é marcada para o resto da vida, porque essa violência você não só sofre na rua, mas você sofre dentro de casa este tipo de violência, sujeitadas aos maridos. Fazer isso - estuprar, isso não tem perdão, isso ai não tem perdão, o pior crime que existe na terra é isso ai, eu não admito, eu não concordo, eu acho repugnante, é melhor matar que estuprar, eu acho.

(vfopinião02)

Apesar de emitido por um único sujeito, traz à tona a questão do papel da mulher na sociedade e da violência doméstica, uma panela de pressão ainda não destampada.

\subsubsection{Categoria $k$ - Explica a violência pela falta de interesse político em mudar a} situação

Eu falo o seguinte: a vítima vai ter esse trauma para o resto da vida dela, a familia dela que paga imposto para sustentar o Governo, se caso esse ladrão, esse estuprador for pego, vai ter que pagar imposto para sustentar vagabundo lá na cadeia. Isso que é triste, é saber que além da vítima ter sido estuprada e morta, se algum dia esse ladrão for pego, você ainda terá que trabalhar dobrado para pagar taxas e impostos para sustentar esse vagabundo que causou tanto mal na sua vida. Não é justo um ser humano viver sempre nessa situação, igual está aqui ou no Rio, e em tantas cidades grandes por ai: As pessoas trabalhando, com medo de vir embora para casa, porque sabe que está correndo sério risco de vida. Está pior do que na selva, mas o que acontece? Não tem ninguém com boa vontade e interesse político para mudar a situação. Só vai mudar no dia em que começar a pegar esses vagabundos, esses políticos que não fazem nada 
para a população e acontecer com eles o que acontece com a população na rua, porque nós somos o povo, nós estamos pagando isso aí.

(vfamiliar06)

\subsubsection{Categoria I - Explica a violência pela falta de solidariedade e pelo silêncio}

Essa é uma violência pior de todas. E a violência mais dura, é que quem viu não ajuda aquela jovem. Porque quando a polícia chega, porque tem polícia boa, tem muita polícia boa, ninguém viu, não sabe quem é, e o cara, às vezes, mora do lado. Às vezes o cara está escondido dentro da casa. Tem que ter solidariedade. Quando nós não formos covardes para contar, olha Fulano é isso, e a polícia também tem que fazer a parte dela, não mostrar a cara de quem contou. Porque se a polícia mostrar, ela é mais violenta de quem foi ajudar. A polícia tem que preservar a pessoa que contou. Mas se a polícia falar, pode considerar que aquela familia ou tem que sumir ou morre. Então aí a polícia é mais violenta ou mais covarde.

(vfamiliar01) 
4.2.3 Terceira Pergunta - Num bairro tem uma briga de dois grupos pelo domínio da área. Gente de um grupo mata pessoas da outra turma. Fale sobre isso.

\begin{tabular}{|ll} 
Categoria & \multicolumn{1}{c}{ Idéia Central } \\
A & Não tem o que falar sobre isso \\
B & Convivência com amigos \\
C & Disputa de pontos de droga e poder \\
D & Impunidade \\
E & Não é violência bandido matar bandido \\
F & Sorte ou Desgraça \\
G & Condições sociais e urbanas \\
H & Falta de segurança \\
I & Corrupção \\
J & Falta de convivência \\
K & Falta de oportunidade
\end{tabular}

\subsubsection{Categoria a - Explica não ter o que falar sobre isso}

Eu acho que é uma violência muito grande. Deve ser muito triste. Nem poderia acontecer isso. Não tenho mais o que falar sobre isso.

(vfamiliar02)

\subsubsection{Categoria b - Explica a violência pela convivência com amigos}

É a violência, é a amizade. Tenho um filho que está preso em Osasco, no mês que vem, completa 20 anos. É o único filho que servia de companhia para mim. Está preso, por causa do que? Até os 12 anos eu segurei ele, dos 12 anos para frente eu não consegui mais segurar. O meu 
velho morreu, o pai dele e ele se ajuntou com pessoas erradas. Dei muito conselho. Não me obedeceu, foi para o caminho errado e hoje está pagando uma coisa. Está preso. Por causa de besteira. A turma dele querendo matar a turma do outro ali, virou aquela guerra; e virou um querer mais que o outro, provar que é maior. Um querendo tirar a vida do outro. Hoje ele está preso pagando o que deve. Esse, praticamente eu perdi, porque uma pessoa que entra nessa vida aí, tem duas saidas, ou a morte ou a cadeia. Então eu acho que esse daí vai ser difícil, ali é só Deus para recuperar esse menino. Porque não entra na cabeça dele que esse caminho é errado. Eu vou visitar de 15 em 15 dias, eu não agüento ficar naquela fila. Eu acho que aquela revista que elas fazem na gente é uma revista assim muito chocante. Mas não sei, pelo que ele fala vai ser difícil mudar. "Eu quero sair daqui para vingar a morte do meu irmão", é isso que ele diz. Então, o que a senhora pode esperar de uma pessoa dessa?

(vfamiliar03)

\subsubsection{Categoria c - Explica a violência pela disputa de pontos de droga e poder}

Isso ai é para tomar conta do lugar. Porque aqui já aconteceu isso há um tempo atrás, quando estava tendo tiroteio praticamente todos os dias aqui; porque uma turma queria tomar o ponto de droga do outro. Era rajada de metralhadora aqui à luz do dia. Isso daí acontece mesmo. Os grupos rivais, um tentando tomar o ponto de droga do outro. Agora parou porque um dos traficantes daqui a polícia matou, mas já tem outros no lugar dele, porque é assim a droga, em todo lugar. Isso aí nunca vai terminar, nunca vai acabar. Então morre um e daqui há pouco já tem outro no lugar tomando conta do lugar, igual aconteceu aqui, um morreu e já tem outros tomando conta. A droga destrói as familias e cada dia está destruindo mais. Morre uma turma, daqui há pouco já surge outra turma, é assim. Quantos nesse lugar aqui já morreram? Quantos? Agora, quantos estão no lugar? Então é assim, morre 10 e daqui a pouco já tem um monte no lugar de novo. A violência só está aumentando. Eles tiram a vida por nada. Aqui ninguém se mete, ninguém fala nada, porque o pessoal tem medo; hoje em dia é o tal do silêncio. Com certeza, violência gera violência. Uma luta por território; com certeza vai gerar violência, só o que acontece no mundo, desde os tempos mais remotos. Analisando historicamente desde os tempos mais remotos sempre houve luta por território, só que naqueles tempos não era considerado violência, era uma coisa comum de acontecer. Hoje soa como violência porque hoje nós temos essa capacidade de dialogar com todos os tipos de pessoas do mundo, naquele tempo mais remoto não existia uma outra forma, o mais forte vencia. Hoje não, a gente tem várias maneiras de estar resolvendo esse tipo de problema igual a este de guerra de gang por território, gerado por causa de pontos de drogas. Acho que todo mundo tem direito de viver, andar. Brigar por um ponto, para um querer ser mais que o outro, é falta de comando. É um querer mandar mais que o outro. Por exemplo, eu moro numa periferia e a pessoa mora em outra, duas bocas que não se dão; uma fica na maldade 
com a outra, o que dá mais morte em salão e onde um mata o outro por causa de drogas, essas coisas. Até acabar, uns vão morrendo e outros vão entrando, nunca pára, um vai morrendo e outro vai assumindo, nunca acaba não. Acho que isso daí e falta de união. É normal nos dias de hoje um bairro brigar com outro. Isso acontece através de desavenças, briga por ponto, um vê o outro crescendo, o grande quer derrubar o pequeno pra ficar com tudo, através da ganância. Hoje o que esta fazendo a violência é o próprio dinheiro mesmo, porque hoje quase ninguém quer dividir o que tem. É um querendo ter mais poder que o outro, querendo dominar. E tem a droga; por ela a pessoa, faz coisa que até Deus duvida. Eu já fui usuário muitos anos do crack. Fui dependente, e graças a Deus eu já me libertei há mais de 10 anos, mas eu fui escravo dele, e se ele falasse faz isso, eu fazia. Então violência gira muito em torno da droga. Existem pessoas que se não tem a droga e ela quer usar, ela faz coisas e não quer nem saber o que está fazendo. Ela mata, ela rouba, ela estupra, ela faz tudo em prol daquilo, daquele vício. Existe muita rivalidade de grupos de bairro, de um bairro para outro para tomar ponto de droga; porque sabe que ali é uma fonte do dinheiro. Disputa de ponto de droga, de domínio do bairro, da rua. O pessoal se enfrenta mesmo para matar, tomar ali e ficar por cima. É um matando o outro. Quem puder mais, chora menos. Ter o dinheiro e o poder. Ser o chefe, dominar e ficar por cima de tudo. Dinheiro acima de tudo. Dinheiro, poder e ganância. Hoje melhorou bastante, uns 70\%; mas quem domina mesmo é o tráfico. É o tráfico e as facções. A gente acha que não, mas é eles que falam - aquela rua vai ter uma boca. Eles põem e acabou. Acontecem brigas de gangues, uma querendo expulsar a outra, invadir o território da outra. Estas gangues geralmente envolvem delinqüentes juvenis, adolescentes viciados ou deturpados em sua personalidade de qualquer forma. Culpa do nosso pais - Brasil.

(vfamiliar04, vfamiliar07vfopinião01, vfopinião03, vprotagonista01, vprotagonista02, vprotagonista03, vprotagonista04,vprotagonista05, vprofsaúde01,vprofsaúde02, vprofsaúde05)

Este é um discurso dominante, compartilhado pelos quatro grupos, porém mais intensamente pelos protagonistas e profissionais de saúde, que são, os últimos, aqueles que primeiro contato t em com as vítimas de violência retratada nessa história.

\subsubsection{Categoria d - Explica a violência pela impunidade}

Eu fico tão indignada que eu não sei nem como falar. Se a polícia investigasse mais, $\theta$ fosse direto na pessoa, punisse aquelas pessoas, se tivesse uma lei mais severa, não aconteceria isso não. É porque não tem. Prender hoje e amanhã soltar, isso aí não vai resolver nada, amanhã eles estão fazendo pior, porque a cadeia é a escola, para a pessoa ficar pior, aprender mais. Prender hoje e soltar amanhã, isso daí não resolve não.

(vfamiliar05) 


\subsubsection{Categoria e - Explica não ser violência bandido matar bandido}

Eu acho que isso é o seguinte, tem uma parte bíblica que diz que tudo que não presta morre por si mesmo. Isso é verdade. Se eu que estou aqui na Terra, não acreditar no que está escrito na Bíblia ... Então tudo o que não presta é destruído por si mesmo. Eu acho que enquanto eles estão se matando, pelo menos o policial não precisou; se Deus meteu um tiroteio entre policial e bandido, se o policial mata um bandido, o policial é punido, o bandido não é punido. Então eles se matam lá e deixa aqui. Era bom que a bala de um, atirada ao mesmo tempo, morresse os dois. Infelizmente só morre um lado, isso é que é o pior, só morre um lado. Porque senão, gente inocente não morria, morriam eles.

(vfamiliaro6)

\subsubsection{Categoria f - Explica ocorrer por sorte ou desgraça}

É um negócio complicado a violência. Muitos, por sorte ou por desgraça, se encontram nesse grupo. Quer seja de um lado ou de outro. Não deixa de ser violência.

(vfamiliar08)

\subsubsection{Categoria g - Explica a violência por condições sociais e urbanas}

O pior é isso, o que atinge mais é ter seus filhos que tem que chegar dentro de casa e você não sabe hora que chega, quem chega, quem esta atrás. Uma violência já generalizada que atingiu todo o campo social. Tomou o caráter de pequenas revoltas civis. Envolve a questão de drogas, de interesses, de comandos, a sobrevivência. Quem não luta por ela? A maioria das pessoas que moram nos bairros, acham que isso não é violência, acham que isto é uma briga entre gangues, que isso faz parte do cotidiano, e isso é uma coisa que assusta. Isto demonstra que as pessoas estão se habituando com a violência e com a criminalidade. Isto não deixa mais as pessoas indignadas. $\dot{E}$ a falta de ocupação do espaço pelo poder público. Tem-se demonstrado em várias ações que a gente tem, como os barracões culturais, que esta falta de ocupação do espaço pela autoridade pública, é um dos fatores que induz a ocupação destas áreas para o crime, pela criminalidade, por gangues, por conflitos. Eu acho que o poder público está concentrado, sobretudo, nas camadas sociais com maior poder aquisitivo, com melhores condições. Estes rincões do território viram terra de ninguém; do jovem despreparado, do jovem sem noção e jogado. É muita falta de oportunidade. Aqui onde a gente mora, aqui não tem nada nesse lugar. Aqui não tem nada. Aqui não tem uma área de lazer. Aqui, quando uma pessoa vai numa festa, é 
briga, é morte. Se quiser se divertir, você tem que ir para fora. Eu acho aqui um lugar esquecido. Só o que tem é violência, se você vai num baile, daqui a pouco tem tiroteio. Ou você sai correndo ou você morre. Falta muita coisa nesse lugar aqui. Os políticos aqui só pensam neles próprios. Não tem emprego. Muitas vezes o jovem entra dentro de casa e não tem nada, não tem uma comida para comer. Então no que ele vai pensar? Ele vai roubar, pensa em roubar, pensa logo num crime. Pensa: só eu não tenho? Então eu vou correr atrás. Procura uma roupa para vestir e não tem. 0 pai e a mãe não têm condições de dar. Eu acho que muitas vezes a pessoa parte para o crime não é porque ele quer, é falta de oportunidade mesmo na vida. Até quando vai continuar esse problema? É nosso, da sociedade, da educação, do próprio companheirismo. Ou então você faz de conta que você não está nem aí. Joga tudo para cima e continua a vida. Coloca um tampão nas vistas. E não pode ouvir, não pode falar, não pode reclamar. Nós somos cidadãos brasileiros, temos direito de tentar resolver nossos problemas, e aí vem a questão: A sociedade quer melhorar, fazer o Brasil melhor, uma pátria, um patrimônio.

(vfamiliar04, vfopinião02, vfopinião04, vfopinião05, vprofsaúde03,vprofsaúde04)

Esta é uma idéia central que permeia várias questões, compartilhada, nesta questão, por três dos grupos estudados.

\subsubsection{Categoria $h$ - Explica a violência pela falta de segurança}

Acho que a situação é bem mais séria. A segurança não é eficiente. Infelizmente, eu acredito que é um absurdo isso, acho que não era para ter mais, porque a gente já tem bastante informação para não ter isso. Porque, eu falo de informação. As notícias estão na Internet, estão na mídia de tudo quanto é jeito. Quer dizer, se um pais consegue controlar de um jeito, os outros podiam também estar seguindo o mesmo modelo. E eu acho que a segurança está um pouco devagar diante da situação que é muito séria para pouco investimento nessa situação.

(vprofsaúde06)

\subsubsection{Categoria $i$ - Explica a violência pela corrupção}

Por que essas pessoas que são rivais têm essa força? Elas têm essa força porque têm uma capa que protege elas. Eles só fazem aquelas brigas, aquelas violências porque eles têm proteção de alguém. Se eles não tiverem essa proteção e se eles não pagassem uma propina, eles não faziam. Porque se a polícia chega ali e leva os dois grupos, prende e não deixa o dinheiro entrar no meio, eles não voltam para a rua para brigar. Eu acho que se não tiver quem protege eles, se fizer a justiça certinha, eles não vão ter como se proteger. Eu tenho alguém da própria 
polícia que me vende a arma. É muito difícil saber que você paga o seu imposto, quando sai do supermercado; quando andou na avenida, já deixou o seu imposto, pagou combustível, também. Todos os lugares você paga o seu imposto. E esse dinheiro é pago para isso. Agora, para mim dar uma vida boa para a minha familia, eu tenho que dar com o meu suor, não com o dinheiro que não é suado, dinheiro ganhado fácil. Aí se eu ganho dinheiro fácil, eu posso comprar carro, eu posso dar carro para amante, eu ganhei fácil. Eu chego lá e eu faço o acerto. Isso é a coisa que está mais triste. Tendo dinheiro, você não fica preso.

(vfamiliar01, vprotagonista05)

\subsubsection{Categoria $j$ - Explica a violência pela falta de convivência social}

Essas pessoas estão sendo criadas sem amor; falta amor do político, do educador, do papai que às vezes nem aparece, da mamãe. Falta a avó, que eles desconhecem... toda essa linha que poderia estruturar o indivíduo.

(vprofsaúde06)

\subsubsection{Categoria $k$ - Explica a violência pela falta de oportunidade para quem tem} passagem policial

O passado da gente discrimina e incrimina bastante. O que aconteceu comigo no passado eu ainda vou pagar muito tempo durante o presente. Qualquer policial que me aborda, se perguntam: você tem passagem? Eu não tenho como mentir, eu vou falar a verdade. Só que o que eu tenho, eu já paguei. E eles sempre falam: ladrão uma vez, ladrão para sempre; puta uma vez, puta para sempre, e não é bem assim. Eu tive uma oportunidade que um amigo deu, confiou em mim. Só que essa empresa faliu. Outro amigo arrumou para mim em outra empresa. Passei nos testes, passei no exame médico, fui aprovado, pediram os meus documentos para poder me registrar, quando viram que eu tinha passagem, ligaram na casa dos meus pais e deixaram um recado que eu não estava enquadrado no rol de funcionários da empresa. Mas por que? Por causa da minha passagem. Então é uma coisa que eu vou pagar pelo resto da vida. Eu acho que tem pessoas que merecem uma oportunidade na vida. Tem pessoas que já mostram que ali não tem conserto. Tem pessoas que não tem conserto, e tem pessoas que querem oportunidade na vida $e$ não tem. Essa é a vida.

(vprotagonista05) 
4.2.4 Quarta Pergunta - Uma criança é trazida ao Pronto Socorro (PS) com o braço quebrado e história de ter caído da escada. Depois de um mês, volta ao PS com manchas roxas pelo corpo. Fale sobre isso.

\begin{tabular}{|ll} 
Categoria & \multicolumn{1}{c}{ Idéia Central } \\
A & Despreparo dos pais \\
B & Falta de estrutura familiar \\
C & Condições sociais \\
D & Silêncio das pessoas \\
E & Agressão doméstica justificada \\
F & Traços culturais \\
G & Consumo de álcool e drogas \\
H & Negligência familiar \\
I & Reação do corpo \\
J & Crise na educação \\
K & Crime dá status \\
L & Não pode ser atribuída só ao desemprego
\end{tabular}

\subsubsection{Categoria a - Explica a violência pelo despreparo dos pais}

Precisa chamar pai, mãe, quem cuida daquela criança na escola ou na casa. E mostrar para a mãe como é a regra para ser mãe. Ver se essa mãe é perturbada, ver se essa mãe não é uma mulher que tem vida irregular, ver se essa mãe não é uma mulher que está querendo ficar livre daquela criança, mandar para o Conselho Tutelar, ou Casa Transitória. Às vezes, ela quer ficar livre e fica espancando. Porque muitas mães, muitas mulheres, não estão preparadas para ser mãe. E não é porque é nova não, mulher já velha, não está preparada. E uma coisa que deveria ser no nosso país, mas isso eu não sei se a gente vai alcançar um dia, essas mulheres que têm um filho, dois filhos, solteira, um já é de um pai, o outro já é de outro, quando ela caísse 
dentro dos hospitais, pronto, o terceiro você não vai ter. Deveria ter uma pesquisa, um Censo, pesquisando. Porque colocar o filho no mundo é a mesma coisa que construir um posto de saúde e não ter médico, enfermeiro para por nele. Ficou só o prédio. $\dot{E}$ um vaso sem água. $E$ quando a mulher tem um filho que ela engravidou sem se preparar, ela não tem amor nesse filho. É mais um que ela vai por, como quando a gente vai ao banheiro fazer uma outra necessidade. Então essa mulher tem que ser chamada e esse pai tem que ser chamado. O problema é com os pais. A gente vê cada barbaridade que a gente se pergunta, não sei por que está desse jeito. No meu tempo não era assim. E cada vez que vai indo, vai piorando mais a situação. Hoje em dia está difícil, hoje em dia, se não souber criar um filho, chega num certo ponto que ele toma conta. Sempre e sempre dei conselho para os meus filhos. "Esse caminho está errado, você tem que ir por esse". Mas deixa de escutar aqui dentro e vai escutar os amigos lá fora. No nosso tempo não existia violência, hoje em dia é o que mais tem. Por isso que eu falo, eu estranho muito. Só que meu pai ainda me dizia, "eu não vou chegar a ver, mas você vai ver, no fim dos tempos vai ser pai contra filho, ou filho contra pai, pai abusando da própria filha". E é o que a gente está vendo hoje em dia.

(vfamiliar01, vfamiliar03)

\subsubsection{Categoria b - Explica a violência pela falta de estrutura familiar}

Eu acho que isso daí já é uma questão da polícia investigar, porque é muita coincidência, pode ter sido até o pai ou a mãe que espancou, porque se ela chega com o braço quebrado e daí depois aparece com o corpo com mancha roxa, eu já acho que é muito acidente para uma criança só. É uma coisa que tem que ser investigada a fundo mesmo. Porque a violência, muitas vezes ela começa dentro de casa. Por isso que muito jovem é revoltado. É caso de estupro dentro de casa, é maus tratos, fome que passa, o pai espanca e a mãe não está nem aí, tem o caso também do padrasto que vai e estupra a menina, a menina chega na mãe e conta e a mãe não está nem aí, muitas vezes a mãe se faz de cega, de surda. A violência, hoje em dia ela está vindo de dentro de casa. A violência está vindo de dentro de casa mesmo. Porque é o que eu estou falando, os pais perderam o poder sobre os filhos por causa desses sem vergonhas assim que machuca a criança, porque educar não é deixar mancha roxa, não é quebrar braço. Educar é igual eu fui educado, eu apanhei do meu pai, eu apanhei da minha mãe, hoje os dois são falecidos. Graças a Deus nós somos em 9 irmãos, não tem nenhuma prostituta e nenhum bandido, Só que nenhum de nós chegou com o braço quebrado. Era aquele negócio, respeito, respeito se adquire, chega um momento que de você só falar, a pessoa já obedece, não precisa ficar batendo toda hora. Esse pai e essa mãe têm que ficar na cadeia lá junto com os malandros para ele aprenderem o que é bom. Isso deveria não existir, mas a gente sabe que existe. É uma violência, mas não deixa de ser um crime também. Uma pessoa indefesa, a quem eles deveriam proteger, eles espancam. Isto tipifica maus tratos ocorridos em família, o que é muito comum. Infelizmente tem acontecido assim muitos 
casos de violência nos lares, essa criança chega no hospital e a mãe vai contar a historia dela; por isso, antes disso, a gente tem que ficar atenta no movimento e olhar, conversar com a criança; Observar o responsável que trouxe. Se não foi citada a violência, é um acidente, mas na maioria das vezes não é acidente não, é violência no lar mesmo. Existe muita violência nos lares hoje, familias desestruturadas, que acabam ocasionando esse tipo de violência. Quando os dois do casal não se unem dentro de casa, então um começa a tirar raiva no outro, pai quer bater na criança por causa da madrasta, ela quer bater na criança por causa do pai, então na vida do ser humano é isso ai, através da desunião dentro de casa um vai desprezando o outro. Pai briga com a mãe e talvez o pai sai e a mãe, naquele desabafo, acaba pondo em cima da criança, maltratando a criança, batendo na criança. Hoje a violência não começa na rua, começa dentro de casa, não tem mais o espírito que tinha antigamente, um pai pelo filho, um filho pelo pai.

(vfamiliar04, vfamiliar05, vfamiliar06, vfamiliar08, vfopinião01, vfopinião03, vprotagonista03, vprotagonista04,Vprofsaúde02, vprofsaúde03,vprofsaúde04)

\subsubsection{Categoria c - explica a violência por condições sociais}

Que negócio é esse que menino cai direto e se machuca? Um menino que se machuca uma vez ou outra tudo bem, mas direto? Ou é o pai ou é a mãe, ou o tio, ou alguém da família que está espancando o menino. É violência. Uma pessoa, uma criança chega lá toda quebrada ainda chega com hematomas, o que a pessoa vai pensar? Toda semana uma coisa? É uma violência com a criança. Muitas vezes é o pai desempregado, a mãe desempregada e eles ficam também muito nervosos. Eu acho que parte até para a violência, para a ignorância. Nossa, eu nunca fiz isso com o meu filho, jamais, mas tem dia que eu fico muito nervosa dentro de casa. Eu grito, eu xingo. Porque meu marido trabalha sozinho, eu vejo faltando as coisas, então eu fico assim já nervosa, começo a gritar, xingar. Mas isso aí não, encostar um dedo no meu filho, jamais na minha vida. Mas tem pai e mãe que o que acontece? A criança começa a chorar de fome e o que eles fazem? Eles vão e batem na criança. Passa aquela raiva todinha e descontam na criança. Acontece muito disso. Acontece que descontam nela, na criança e dai é pior, vai gerar mais violência. $E$ hoje em dia está tudo muito difícil, problemas de alcoolismo, problemas de passar necessidade e fome. Mas hoje, em centros urbanos é uma correria tão grande que os pais não têm tempo pra ficar com os filhos, e os filhos acabam crescendo mais rebeldes; então incita muito um ato desse gênero violento, então a gente tem que pensar muito nessa situação porque ela acontece muito, mesmo com o estatuto da criança e do adolescente em vigor, que é um perigo para os pais serem até presos, mas mesmo assim acontece com freqüência esse tipo de violência. $\boldsymbol{A}$ pessoa cresce revoltada e chega uma certa idade em que ele vai ter que se virar e daí se torna uma revolta. Muita classe alta mete o pau na classe baixa que é a gente, porque não sabe a vida da gente, não sabe o que aconteceu. Ninguém sabe o que se passa do outro lado, a minha vida ninguém sabe, 
tem meu aluguel, se não tiver o meu aluguel estou na rua, vou sair e dar meus pulos, mas eu mesmo tenho que fazer o meu arroz com feijão, eu mesmo lavo a minha roupa. Cada um tem que resolver os seus problemas. É, sou carta fora do baralho, eu me rendo, deixo o barco rolar, mas jamais botar um filho meu no crime. Tem criminoso que pensa: eu quero montar tudo que for de bom no crime, pra amanhã ver um filho meu trabalhar com o que foi meu, para não passar pelo que eu passei, porque hoje em dia é fogo, quem entra não sai mais, e quem fica morre.

(vfamiliar04,vfamiliar07, vfopinião04, vprotagonista03, vprotagonista04)

\subsubsection{Categoria d-Explica a violência pelo silêncio das pessoas}

Qualquer tipo de violência eu sou contra: de criança, de idoso, qualquer tipo de violência eu sou contra. Eu tenho a falar isso: aqui é um lugar que você tem que andar de dia, não tem que sair de noite, fora as outras coisas que aparecem por ai que as outras pessoas não querem falar, não tem nada que falar.

(vfopinião02)

\subsubsection{Categoria e - Explica a violência por agressão doméstica justificada}

Uma situação que deve ser analisada. Acredito que o organismo possa ter tido alguma reação natural que fizesse estas manchas roxas, porém pode ser resultado de que estivesse brincando na escada e levou uma surra por causa disso. Então é questão de se analisar mesmo, de ir atrás da história. Não sei se me fiz entender. De repente ela voltou para casa e está lá em cima da escada; levou uma surra e está roxa.

(vfopinião04, vprotagonista01,vprotagonista02, vprotagonista03)

\subsubsection{Categoria $f$ - Explica a violência por traços culturais}

Tem que ser apurado. Tudo isso é pelo menos suspeito. Nos induz a imaginar, com a freqüência que esta criança vem ao pronto socorro e é atendida com estes traumas, que ele pode está sendo vitima também da violência doméstica, que é um desdobramento da violência urbana, da violência da rua, da violência do cotidiano. Induzida de várias formas, pela mídia, pela televisão, pela cultura americana que nós recebemos. A cultura americana que está enraizada hoje no mundo, e sobretudo no Brasil, é a cultura da violência. As pessoas buscam a paz através da guerra. Quer uma dicotomia maior do que esta?

(vfopinião05) 


\subsubsection{Categoria g - Explica a violência pelo consumo de álcool e drogas}

Acontece isso muito na nossa sociedade aqui no bairro, de criança ser violentada fisicamente; a gente escuta a familia brigando, muita bebida e os pais chegam e batem. Vejo caso de meninas grandes, moças, que apanham do pai mesmo, apanham da família. Sabe por causa de que? Álcool. É o pai de família que chega embriagado em casa e não respeita a mulher, não respeita filho, não respeita pai, não respeita mãe. Tudo em torno do álcool. Gera muita violência. Tem pessoas que sem beber são tranqüilas; bebeu, parece que ela vira um super-herói, um Heman da vida. Isso eu falo porque a gente vê. A gente vê as pessoas chegarem no bar sãs, lúcidas, beber e daqui a 1 hora o estado dela muda. Ela já fica brava, o tom de voz altera, já fica valente. Muita violência dentro de casa é gerada pelo álcool. É o álcool, a droga em si que causa muita violência, $90 \%$ é o álcool, a droga. Pai e mãe usuários de droga e de álcool. Contam uma história diferente para livrar uma coisa, uma ocorrência, e aí volta a acontecer a mesma coisa, não têm em quem descontar e acabam fazendo isso daí mesmo. Por causa de droga, álcool. Desconta na criança que não tem nada a ver. As crianças são vítimas de pais drogados, de pais que agridem. Vou te falar a real: se um dia um filho meu cair no mundo da droga quero que ele chegue pra mim,e converse. Eu prefiro ensinar para o meu filho o que presta e o que não presta e muitos pais hoje não têm esse dialogo com os filhos, então os filhos vão procurar os outros na rua pra entender o que é a droga.

(vfopinião06, vprotagonista03,vprotagonista04, vprotagonista05, vprofsaúde01, vprofsaúde02, Vprofsaúde04)

A identificação do consumo de álcool e drogas como causa de violência em geral, doméstica e em especial contra a criança, encontra respaldo na literatura sobre o tema.

\subsubsection{Categoria $h$ - Explica a violência por negligência familiar}

Isso mostra uma falta de cuidado, de vigilância da família. De qualquer maneira você tem que pensar em negligência da familia em olhar a criança, cuidar da criança. Eu acho que é pura irresponsabilidade e falta de impunidade. Eu acho que se os pais levassem uma chamada, bem chamada, acho que diminuia mesmo. Não só quedas e braços quebrados e manchas, hematomas que chegam por causa de queda em escada, queda de laje; mas também os acidentes domésticos que muitas vezes acontecem por causa de descuido das mães, que deixam ao alcance da criança a cândida, o detergente.

(vprofsaúde04,vprofsaúde05,vprofsaúde06) 
O tema da negligência é trazido pelos profissionais de saúde, como um retrato de sua prática profissional.

\subsubsection{Categoria $i$ - Explica a violência como em conseqüência de reação do corpo}

Eu mesmo já tive manchas roxas e as vezes é conseqüência de um momento, uma emoção, de um momento mesmo de sua vida. É relativo.

(vfopinião04)

\subsubsection{Categoria j-Explica a violência pela crise na educação}

Hoje os colégios não estão valendo mais nada, ninguém se interessa em colégio. Vão em colégio pra marcar horário, ver as menininhas, fumar um baseado dento do colégio; a maioria faz isso, você não vê um estudante chegar em casa, pegar um livro e dizer: tenho uma lição de casa, no sabadão estar estudando. Hoje você não vê isso, o estudo hoje está acabado, está por fora. Eu tiro por minha casa mesmo. Meu filho esta na $6^{a}$ série e não se interessa em nada. Hoje a maldade está começando na porta dos colégios. Tem muita gente que vai para o colégio não com o interesse de aprender, é de ensinar a alguém a maldade, de ensinar para um outro amigo dele a maldade também, então hoje o crime está começando na porta do colégio, o tráfico está na porta dos colégios.

(vprotagonista04)

Apesar de manifestado por uma única pessoa, a questão da educação é trazida como um caminho a se contrapor à violência, mas também como complacente e mesmo gerador de violência.

\subsubsection{Categoria $k$ - Explica a violência pelo fato de os jovens acharem que o crime} dá status

O crime é um lugar que você entra e não sai, então eles vão entrando pensando que o crime é tudo e o crime não é pra quem quer, é pra quem tem a sorte. É um dom, se você tem dez homens e nenhum dos dez é criminoso. vai só sofrer no crime, vai morrer. Vai tirar cadeia, vai virar pilantra. O crime é só pra quem tem o dom mesmo, eu sempre tive o dom pra criminoso. Comecei o crime com 11 anos, eu não tinha familia, morava na rua, ficava jogando num canto, no outro, pedia esmola nas portas, então eu comecei o crime de moleque, então eu sei o que é o crime. Os caras hoje não, eles entram no crime pra dizer que é criminoso e o crime não é tudo na vida. Acham que dá status e estão enganados. Os moleques que começam hoje com quatorze anos não 
chegam aos vinte anos. E agora tem um tal de partido que abriu, o tal do PCC, que é só pilantragem. Os caras só querem saber de destruir famílias.

(vprotagonista04)

\subsubsection{Categoria I - explica a violência não poder ser atribuída só ao desemprego}

Toda semana uma coisa? É uma violência com a criança, eu acho. O mundo hoje é só violência, você escuta só violência o tempo todo. O pessoal fala de desemprego, mas eu já não acho que seja desemprego. Não é porque eu estou desempregada que eu vou entrar numa vida dessa. Ou a minha filha, meu filho, o que seja. Eu acho que por aí não é o caminho.

(vfamiliar07)

Apresentado por um único sujeito, este discurso encontra respaldo em estudos que abordam ser a violência produzida por pessoas de diversas classes sociais, não sendo o desemprego ou a condição social do agente agressor o determinante de sua conduta, haja vista os constantes relatos de crimes contra a vida cometidos por jovens de classe média e alta. 
4.2.5 Quinta Pergunta - Comerciantes, cansados de serem assaltados, contratam "seguranças particulares". Estes matam uns rapazes negros, apontados como sendo os assaltantes. Fale sobre isso.

$\begin{array}{cl}\text { Categoria } & \text { Idéia Central } \\ \text { A } & \text { Não encontra explicação } \\ \text { B } & \text { Preconceito e racismo } \\ \text { C } & \text { Estar cansado de sofrer violência } \\ \text { D } & \text { Descrédito do Estado } \\ \text { E } & \text { Existência de poder paralelo } \\ \text { F } & \text { Influência da mídia } \\ \text { G } & \text { Motivos morais } \\ \text { H } & \text { Tentar resolver violência com violência } \\ \text { I } & \text { Falta de políticas públicas de prevenção } \\ \text { J } & \text { Desorientação dos pais } \\ \text { K } & \text { Impunidade }\end{array}$

\subsubsection{Categoria a - Não encontra explicação}

Eu acho que não é certo. Não sei em outros casos, aqui não.

(vfamiliar02)

\subsubsection{Categoria b - Explica a violência pelo preconceito e racismo}

É o preconceito da cor escura, Isso aí acontece mesmo. Cada pessoa é uma pessoa, tem pessoa que não gosta da cor preta. Para mim é tudo igual, eu me dou com todo mundo, graças a Deus. É mais um equivoco, o julgamento pela aparência. Muitas vezes o ser humano erra muito porque julga pela aparência, só vê o exterior. A discriminação é muita contra o preto, no Brasil existe sim o preconceito. É negro, então já é uma caracterização do crime, do roubo, do assalto. Eu acho que para tentar fazer justiça com suas próprias mãos. Primeiro você tem que ter certeza de que são aquelas pessoas, porque senão você está cometendo um outro crime. Sei lá o que o pessoal tem contra os negros. É capaz que os brancos hoje em dia apronta mais que os pretos. $O$ racismo, o preconceito é erradíssimo. $E$ se os amigos daqueles negros voltam e matam a família 
do comerciante, matam a familia do segurança. $O$ que gerou? Mais violência, então não resolve nada. É lógico que tem todas as raças envolvidas na violência e não pode ser combatida nessa forma. A gente não deve rotular as pessoas, esses rapazes de assaltantes. A não ser que tenha havido um fato evidente de que esses rapazes tenham praticado esse delito. Mas realmente, as pessoas de cor negra são estigmatizadas, em qualquer e na maioria das situações de violência. Será que se fossem dois brancos, tinham matado? Se um negro passa, já ficam tudo de olho nele, se passa um branco, ninguém olha. No Brasil existe muito racismo. É racismo contra o pobre, contra o favelado, contra o negro, contra as prostitutas, você vê até contra os nordestinos. Então o racismo já vem da pessoa, já vem de casa. Igual passou na televisão: olha aquele macaco, olha aquele negro; ele já vai crescer com aquilo, ele já vai crescer uma criança racista.

(vfamiliar03, vfamiliar04, vfopinião01, vfopinião02, vfopinião04, vprotagonista01, vprotagonista 02,vprotagonista05, vprofsaúde01,vprofsaúde04,vprofsaúde05,)

Discurso compartilhado por todos os grupos, que identificam o racismo e preconceito como relacionados à violência.

\subsubsection{Categoria c - Explica a violência por estarem cansados de sofrer violência}

Esses seguranças já foram contratados para proteger o comércio, por não agüentar mais de tanto assalto. Hoje em dia tem segurança em tudo quanto é lugar. As pessoas têm tanto medo de ser assaltada que elas próprias estão contratando esses seguranças. Eles terem matado os dois assaltantes, eu acho que eles estão mostrando o serviço deles. Porque o pessoal vai na delegacia, dá parte, mas não adianta. Por isso que o pessoal vai por esse caminho, os comerciantes ficaram cansados de ser assaltados. Eles cometeram um erro porque eles contrataram pé-de-pato. Eles têm que ir atrás da polícia, exigir do delegado segurança. Porque o pé-de-pato, ele mata e depois um dia ele volta para ser assaltante, volta para assaltar o próprio comerciante. Um dia que ele não tiver mais quem paga para ele, ele vira para o lado do bandido. Agora, se o segurança está ali para ajudar, orientar, tudo bem. Na periferia, o que eles estão fazendo? Estão contratando muito segurança, principalmente segurança que mora no próprio bairro mesmo e já conhece a malandragem, já conhece todo mundo ali, já para evitar esse tipo de coisa.

(vfamiliar01, vfamiliar03,vfamiliar04,vfamiliar07, vprofsaúde01)

Apesar de identificarem esta situação como de violência, apresentam justificativa para a prática. 


\subsubsection{Categoria d-Explica a violência pelo descrédito do estado}

É uma situação que ocorre principalmente na periferia, nos bairros mais violentos como o jardim Ângela, Santo Amaro na zona sul de São Paulo. Os comerciantes não têm, por $n$ motivos, $o$ apoio que eles gostariam de ter por parte do estado, da polícia, então como eles não têm a proteção que eles acham que deveriam ter e talvez fosse a ideal, eles contratam seguranças particulares que realmente procuram fazer justiça pelas próprias mãos e normalmente os mais atingidos são os pretos e pobres. Pé-de-pato é bandido igual a molecada. Se ele está matando, ele é bandido também. Acho que quem deveria fazer a lei, são esses políticos, esses legisladores aí, e a lei deveria ser cumprida, mas deveria ter um sistema, um julgamento. Porque não é justo a molecada sair na rua com uma arma, e só porque não gostou da cara do outro, ir matando. Por falta de uma política mais séria que surge esses pé-de-pato da vida aí, para sair fazendo justiça com as próprias mãos, o que também não é certo. Eu acho que o Estado deixa muito a desejar, em todos os aspectos. Você vê, aqui nós temos uma lixeira, com um monte de lixo aqui na frente. Seria para um caminhão vir dia sim e dia não. Às vezes passa 2 ou 3 semanas sem passar. E cadê os vereadores? cadê todo mundo? Tem que tomar uma atitude. A Prefeitura só sabe arrecadar. Eles deixam a desejar em todos os aspectos. Ai começa a surgir esse pessoal aí, matadores, que são bandidos também. Porque a partir do momento que alguém está disposto a tirar a vida de um, seja ele quem for, ele é bandido também. Eu acho que deveria ser tirado pelo Estado. O Estado deveria ter um poder que, dependendo do crime que a pessoa cometesse, matou, morreu. Mas ser morto pelo Estado, para ser julgado em cadeia de televisão, para todo mundo ver, e ninguém virava bandido. A segurança é uma atribuição do estado. Não se deve e nem se pode fomentar iniciativas desta natureza. Atuar de forma preventiva é correto. Você tem outros meios, agora uma reação a esta violência que nós vivemos, com os mesmos instrumentos dela, acaba gerando mais violência. É a ausência do estado, no que diz respeito a esse serviço público de preservar a liberdade, o direito de ir e vir, de compra, da família e assim por diante. $O$ pessoal não acredita muito na justiça. Deveria contratar uma pessoa para descobrir quem estava fazendo e chamar a polícia para resolver, deixar que as autoridades ajam. Senão a gente não termina com a violência. Eu acho muito precipitado a pessoa ir lá e resolver com a própria mão. Tem que procurar a polícia. Se tem uma lei para resolver essa situação, então deixe que essa lei resolva, não vai querer fazer segurança com as próprias mãos, porque violência gera violência.

(vfamiliar06, vfamiliar07, vfamiliar08, vfopinião03, vfopinião05, vprofsaúde04, vprotagonista05)

O descrédito de instituições volta a parecer enquanto gerador de violência. 


\subsubsection{Categoria e - Explica a violência pelo poder paralelo}

O comerciante agiu errado. O certo é conversar com o pessoal mais velho da área, os traficantes, ver os ladrão bom que moram ali. Não deixar ninguém matar, porque eles mesmo dão um sumiço. Porque se ele contratar alguém de fora pra matar, então nunca tem respeito, quem mora na área nunca dá valor, então o certo mesmo é o pessoal da área, os traficantes ou uns bons ladrões que tem na área não deixar acontecer roubo na área, porque na área que a gente mora mesmo não pode ter essas coisas. Os próprios comerciantes têm um pacto com o bandido, para que consiga manter esse comércio no ambiente. Ele faz o pacto, inclusive esses seguranças normalmente são ligados a esses outros marginais, para que consigam ficar e manter o comércio. Ele não consegue manter um comércio num bairro como o nosso, assim na boa. Ele tem que ter esse pacto com alguém que ele conhece ou que não é bandido e que conheça o bandido e mantém a coligação. Eles preferem até fazer isso para manter o comércio, senão não consegue manter. Envolve também as pessoas, policiais até, outros tipos de segurança. E aí eles põem uma lei. Essa lei é que no reduto que eles estão ninguém pode roubar ou furtar. Eles não vão querer que a área deles seja atacada por ninguém. E os comerciantes que ganham nisso. Porque eles botam esses seguranças, ai eles pagam para esses seguranças. Além de pagar, os caras têm 0 que eles querem do mercado para se manter com a família. Para que ninguém de outra área invada o comércio deles.

(vprotagonista03,vprotagonista04,vprofsaúde02, vprofsaúde03, vprofsaúde05,vprofsaúde06)

Apesar de identificar a situação como de violência, é sugerido o pacto com bandidos como a forma adequada de lidar com o problema.

\subsubsection{Categoria f - Explica a violência por influência da mídia}

Hoje ninguém é punido, filho rouba, chega com esse gravador aqui e fala para a mãe, olha o que eu achei; ô meu filho, acha outro para a gente. Mentira, o moleque roubou. Então, tudo isso, é a corrupção que está generalizada. Infelizmente, dentro das casas, o pai e a mãe, ao invés de educar o filho, ensinar princípios bíblicos, o sentido assim da vida, que é a família, o amor de Deus, que é interessante; as pessoas hoje em dia se encostam na porcaria da televisão; só querem ver porcaria de Big Brother e Casa dos Artistas e mais não sei o quê, que não leva a nada, não edifica a familia de ninguém. Só destrói. Uma menininha de 12,13 anos, ou às vezes menos, está vendo a prostituição na televisão. Ela vai virar o quê? Ela vai aprender o quê? O pai e a mãe do lado, assistindo. Antigamente, o pessoal se preocupava um pouco em conversar, não tinha tanta televisão espalhada, eu não sou contra televisão, eu sou contra os programas que passam na televisão e ninguém tem coragem de tomar uma atitude quanto a isso. Porque a televisão poderia ser um meio educativo, divulgar coisas interessantes. Poderia passar as coisas que quisesse, mas 
num canal fechado, tipo esses canais de assinatura. Hoje fica-se discutindo a televisão, por exemplo. A violência na televisão. Como ela influi na violência futura de um jovem. Discute-se o sim e o não e parece uma discussão eterna e não se chega a uma conclusão para fazer o trabalho.

(vfamiliar06, vfopinião04)

\subsubsection{Categoria g - Explica a violência por motivos morais}

Hoje em dia é a fraqueza do ser humano voltada para o que não presta. É o pecado em geral. É a cabeça do cara, vai acontecendo uma lavagem cerebral que daí a pouco ele acha que tudo é normal. Hoje em dia nudismo é normal na cabeça de muita gente. Isso não é normal. Teria que aquele primeiro que inventou, fazer uma praia de nudismo, chegasse um chicote nas costas dele, o outro que estava até pensando nisso não vai mais. A familia está sendo destruída, as meninas estão virando prostitutas, os moleques, um matando o outro no meio da rua. Matando inocente, que não tem nada a ver. Tudo isso por causa de cabeça fraca, falta de princípio das próprias pessoas.

(vfamiliar06))

\subsubsection{Categoria h - Explica resolver violência com violência}

O outro aspecto é o da violência mesmo. Quis resolver a violência com violência. Sabemos o resultado disso.

(vfopinião04)

\subsubsection{Categoria $i$ - explica a violência pela falta de políticas públicas de prevenção}

Um aspecto é o de tentar resolver a violência imediatamente, pelo caminho mais fácil. Mas por um caminho que normalmente não dá resultado porque a violência não é uma questão só de ser inibida, mas de ser evitada. É uma questão, como se fala na saúde, de prevenção. Deve ser prevenida e não remediada. É um aspecto muito interessante, sobretudo de políticas públicas. Trabalha-se até bastante no remediar, no controlar, no reprimir a violência, mas falta muito ainda trabalho de educação de filhos, de família, incutir, transmitir, eu sei que incutir fica muito forte, mas transmitir valores para as familias. Educar os desvios.

(vfopinião04) 


\subsubsection{Categoria $j$ - Explica a violência pela desorientação dos pais frente o mundo} atual

Os pais estão perdidos com a educação hoje. O mundo mudou muito e os pais ficam perdidos mesmo. Tem pais ai que perguntam "o que que eu faço?" e este o que que eu faço já é para mim o desespero. A mudança cultural é tão grande que eles não sabem o que fazer. Conclusão de tudo isso: se em casa não tem limite, socialmente não vai ter. Então é onde desemboca também a violência, onde se conclui casos como este aí.

(vfopinião04)

\subsubsection{Categoria $k$ - Explica a violência pela falta de ordem e punição}

Falta de política séria para conduzir tudo. Muita gente fala que a ditadura não é boa, eu sei que não era boa, mas pelo menos tinha ordem e as coisas só são boas quando tem ordem. Não adianta a pessoa pensar que baderna, bagunça aí é boa, que não é. Baderna não é bom para ninguém. Não é voltar à ditadura militar não, é simplesmente ter ordem. Porque a partir do momento que não tem ordem, o governo não tem pulso, porque pensam que o governo é quem manda, mas quem manda, as safadezas aí são os deputados e vereadores, são eles que fazem as leis. Tem que ser mais duro, igual um monte de paises por aí. Igual na China, eu não conheço nada de fora do Brasil, mas já ouvi dizer que se o cara comete um crime bárbaro, ele deve morrer em praça pública e a familia tem que pagar a bala que ele foi executado. Eu acho que isso seria 0 correto. Então eu acho que quem cometeu um estupro ou tirou a vida de alguém tem que ser executado. Então é o que eu te falo, a lei, quando ela funciona, ela funciona para pegar o mais fraco, porque o forte nunca pega. Ai, se tivesse uma lei séria, resolve o problema. Todo mundo tem medo de ser punido, pode ser juiz, delegado, todo mundo tem medo de ser punido.

(vfamiliar06) 
4.2.6 Sexta Pergunta - Como você acha que os serviços de saúde poderiam contribuir para a redução da violência?

\begin{tabular}{|cl}
\hline Categoria & \multicolumn{1}{c}{ Idéia Central } \\
A & Atender bem \\
B & Não é papel da saúde \\
C & Não é papel da saúde e sim da escola \\
D & Não é papel da saúde e sim da segurança \\
E & A saúde é violenta \\
F & Papel de promoção e orientação \\
G & Exercer controle social \\
H & Fornecer informações importantes \\
I & Na somatória de esforços \\
J & Não cumpre seu papel
\end{tabular}

4.2.6.1 Categoria a - Explica o papel da saúde como sendo o de atender bem e dar condições de trabalho a quem é da saúde

Eu acho que eles devem trabalhar melhor, ter dó das pessoas, atender melhor as pessoas. Eu já vi muita gente aqui no posto de saúde, doente e não é atendido. O que você vai fazer? Você joga cadeira na parede. Eu já vi mãe virando maca nesse posto, porque o filho estava morrendo. Eu já vi mesmo, eu sou testemunha, o filho está ali morrendo e o médico simplesmente está ali sentado. Aquilo foi uma violência que ela fez, mas por que ela fez aquilo? Foi para chamar a atenção, para salvar o filho dela. Agora, se tivesse na hora que ela chegou, acudido o filho dela, atendido, jamais ela faria uma violência daquela. Eu acredito que quando o atendimento é bom não tem agressão, agora se não for bom tem agressão sim, é por parte de mulher, por homem, quem é bandido, quem não é mais. Cuidar independente de quem seja, da onde vem, de raça, de cor. Eu acho que ajuda demais quando a saúde atua efetivamente, de forma competente e justa lá no bairro, no território. Acho que os agentes de saúde são um instrumento extremamente importante, que mostra efetivamente que o poder público, o estado está lá. É um meio de pesquisa, de detectar a violência doméstica. Por exemplo, a criança; acho que o senviço de saúde pode por um trabalho nesta linha. Primeiro detectar e segundo, o trabalho com a familia, através de psicólogos e 
assim por diante. Pode oferecer condições de tratamento psicológico e tratamento medicamentoso, tratamento dos feridos, curar as feridas depois de estabelecida a coisa. Também tem que ver que pagam muito pouco para o médico. Não dá incentivo para a pessoa que está se formando em medicina, ter esse prazer, falar: eu vou ser funcionário público, eu vou trabalhar para o Estado, para o Município, aí o que acontece? Quando o salário é tão pouco, ninguém quer exercer a função de médico. Vai trabalhar numa vila, só que também está expondo a vida dele ao perigo. Aqui mesmo tem casos de pessoas que vão ser socorridas no Posto e na frente do médico ele é baleado e assassinado e o médico tem que ficar calado, olhando o cara matar ele. Então o médico, não tem razão nenhuma para trabalhar nesse Posto. Ai já vai trabalhar com má vontade porque está ganhando pouco, estudou tanto para ganhar pouco, e as autoridades não têm capacidade sequer de melhorar um pouquinho o salário e dar incentivo, até mesmo faculdade gratuita para as pessoas que não tem condição e tem boa vontade, se formar para a área de medicina. Porque se tivesse mais gente formada, já não teria esse problema. Neste posto já aconteceu muita coisa que todo mundo sabe sobre violência, já mataram gente lá dentro, que nem o cara foi lá e obrigou que o médico fosse atender ele, puxou um revolver e falou: você vai me atender ou não vai me atender? Quer dizer, quem trabalha não tem culpa, de chegar uma pessoa armada e apontar a arma, você é obrigado a atender.

(vfamiliar02, vfamiliar04,vfamiliar06, vfopinião02, vfopinião05, vprotagonista05, vprofsaúde05, vprofsaúde06)

É discurso que permeia os quatro grupos de entrevistados o de ser papel da saúde na questão da violência, o bom atendimento.

\subsubsection{Categoria b - Explica não haver papel específico da saúde e sim do} desemprego

Não tem nada a ver com a saúde. Acho que foge um pouco da área da saúde. Foge um pouco do objetivo da saúde. Agora o Presidente tem. Foi depois desse desemprego que gerou isso. Porque esse menino que eu estou falando que está preso, ele era cobrador de perua, aí houve aquela época que menor não podia trabalhar e ai jogaram o meu filho para o lado de fora. Foi aí que ele conheceu esse cara e foi ai que ele levou o moleque, aproveitando do moleque por estar parado e precisar de dinheiro. Quando eu fui descobrir, já foi tarde demais, o meu filho já estava infiltrado no meio deles. Era roubo de banco, era roubo de caixa eletrônico, era roubo de carga. Então ele já acostumou com aquele dinheiro fácil. Não queria saber de derramar o suor para ganhar o dinheiro sagrado, mas só que o feitiço virou contra o feiticeiro. 
Quando ele foi preso não tinha dinheiro para pagar o advogado. Por isso que está hoje lá. Então, por isso que eu digo, a saúde não tem nada a ver, o que tem a ver é o desemprego que está levando a violência a cada dia que passa e piorando mais.

(vfamiliar03,vfamiliar07, vfamiliar08, vprofsaúde05)

\subsubsection{Categoria c - Explica ser papel da educação}

Eu acho que um pouco da violência parte da educação. O certo mesmo é a educação. Eu acho que criar mais espaço, cobrar mais do jovem em si, cobrar o ensino dele e saber que se ele não vai ter ensino ele não vai ter nada. Então, hoje, o aluno vai para a escola, ele faz o que ele quer. "Ah professor, a gente não quer a lição". O professor vai e não passa lição. Para acabar um pouco da violência eu acho que o estudo, a educação tinha que ser em primeiro lugar. Não tem a ver com saúde, tem a ver com escola.

(vprotagonista01, vprotagonista04)

\subsubsection{Categoria d - Explica ser papel da segurança, não da saúde}

Sobre a violência de rua não tem como ajudar. Acho que pode, todo mundo trabalhando de casa em casa, batendo no portão pra ver como é que esta a saúde das crianças, ajuda muito na vida da favela, agora a policia tinha que fazer a parte dela ir atrás pra tentar resolver os problemas. Se a policia fosse de ir atrás pra resolver os problemas dela mesmo, aliás a polícia sabe onde estão os problemas só que eles não resolvem, eles só passam para ver, mas se eles chegassem mesmo pra resolver os problemas, ai todo mundo resolvia. Porque polícia é estudada pra isso, pra ir atrás de ladrão. Eu acredito que já entrou pra isso e se já entrou pra isso porque não resolve? Eles são treinados pra resolver e não resolvem. Eu acho que Itapecerica da Serra deveria agir mais, acho que deveria ter mais segurança, mais policia, uma coisa assim que viesse a melhorar a situação.

(vprotagonista02, vprofsaúde06)

\subsubsection{Categoria e - Explica que a forma de atendimento da saúde pode gerar violência}

As pessoas estão sendo muito maltratadas, tem muita enfermeira e médico que não cumpre com a sua obrigação. Deveria colocar pessoas competentes, pessoas de pulso, com cursos, com estudo. Acho que todo mundo que se forma pra médico e pra enfermeira tem que 
passar pelo psiquiatra, porque tem muita gente maldosa.Tem muitas pessoas que precisam de auxilio e vai até a unidade que mora, a unidade está pronta a ajudar, a unidade faz por onde ajudar, mas quando passa por uma parte de saúde que precisa de hospital, que precisa de parte documental, sei lá, de Estado, barra, por causa que o município não tem como fazer. Eu vou dar um exemplo, a pessoa precisa de uma ressonância magnética. O Posto, o médico, passa pelo médico e o médico solicita essa ressonância magnética, aí vai para uma Secretaria que tem que pedir para o Estado, porque é o Estado que fornece, porque o município não tem isso. Então, essa pessoa espera 2 ou 3 anos para fazer essa ressonância magnética, porque o Estado, o Município não tem como fazer, ai pede para o Estado e aí aguarda. Eu vi caso que quando consegue, que a pessoa da saúde vai até a casa - olha conseguimos a ressonância e tal - a pessoa já morreu. Pra mim é uma violência. Pra mim isso é muito mais que, até mais que um cara que bebe. Porque é uma violência contra a pessoa, uma grande violência. Tudo bem, que não é um exame que vai fazer a pessoa viver, lógico que não. É uma coisa que para mim é uma violência. Pode acontecer comigo, pode acontecer com um familiar, com qualquer um de nós. Só que para muitos tem recurso e para outros não tem. Hoje a saúde em si melhorou bastante, mas precisa de muito, muita coisa, muita coisa também. Mas a vontade das pessoas também, os próprios funcionários. Também há muita discriminação nos serviços de saúde que também gera violência. Eu acho que deveria ter mais união entre a comunidade e a saúde, a comunidade em si, de bairro, e as escolas. Porque se houver esse trio, ai sim nós vamos combater a violência. É longo prazo, mas nós vamos combater. Porque a comunidade tem que participar, ela tem que saber pra que serve um posto de saúde e que lá o posto de saúde também sofre por esse povo.

(vfopinião01,vfopinião06, vprotagonista03,vprofsaúde02vprofsaúde05)

A saúde enquanto geradora de violência pela sua forma de organização e prática é identificada inclusive por profissionais da área.

4.2.6.6 Categoria $f$ - Explica que a saúde tem o papel de fazer trabalhos em promoção à saúde

Eu creio que pode ser em termos de informação, porque é um lugar em que as pessoas tem um contato com esse tipo de serviço público; creio que eles tenham um papel importante na área informativa, poderia levar o pessoal à reflexão, através de informações, de slogans sobre tipos de violência e também no tocante a parte social. Porém vejo que estão muito longe disso. $A$ saúde é tratada em pontos localizados. A pessoa está com problema de dor de ouvido, então dá antibiótico para melhorar a dor de ouvido. No entanto, aquela dor de ouvido que precisa certamente de um antibiótico pode ser resultado de uma vida de tensão, do desemprego, de uma situação emocional muito complicada. Então o tratamento se dá num ponto localizado, $A$ partir do 
momento em que a saúde de uma pessoa for tratada como um todo, pensar na saúde da pessoa e não no ouvido, no problema de estômago. Pensar a saúde da pessoa, é um papel da saúde. Fazer trabalhos com a familia, seria positivo, pois já é um caminho para esse todo. Bastante palestras, falar, não só da violência criminal, mas a violência dentro da própria casa. É unir o que a gente tem; no caso, saúde, o posto de saúde, as escolas, comunidades de bairro. Precisa se unir trazendo coisas novas, fazendo palestras, o posto ajudando com as palestras, tanto na questão da violência, não só a violência que a gente conhece, porque fala violência e parece que é só matar e roubar, e não é isso, é a questão da violência sexual, a questão das drogas, as bebidas. Então se orienta, se previne. Palestras, reuniões, convocando principalmente esse pessoal mais conhecido do bairro, que são mais antigos, que tem um conhecimento, principalmente chamar esse donos de boca, esses traficantes que são mais, costumam dominar mais, que tem uma amizade. $O$ serviço de saúde pode, por exemplo, quando chegar um caso de violência no serviço de saúde, fazer um trabalho de conscientização, de educação com os familiares, orientando a familia para procurar serviços que possam orientar. Já é alguma coisa. Já é um primeiro passo.

(vfopinião01, vfopinião04, vfopinião06, vprofsaúde01, vprofsaúde03,vprofsaúde06)

Além de "atender bem", o papel identificado como sendo próprio ao setor é o de ações de promoção e educação em saúde.

\subsubsection{Categoria g - Explica o papel da saúde em exercer controle social}

Eu acho que a saúde, para reduzir a violência deve chamar as familias e ter uma conversa. A saúde pode, no conversar com as familias, exigir que as famílias, junto ao Poder Jurídico, Judiciário, exigir que as famílias dêem apoio àquela pessoa, não achar que não tem nada mais para fazer, tem muito para fazer ainda. É aí que está começando o trabalho. Porque não adianta $o$ médico costurar o esfaqueado, cuidar, dar remédio; se a família não olhar. Amanhã ele vai pegar uma moto e vai fazer o que? Ele vai sair numa moto, roubar, fazer tudo o que não presta, porque ele não está são. Ele é um dependente para o resto da vida. Então eu acho que a saúde, nessa parte pode exigir que a familia venha, a saúde deveria ter essa força para ela, o Jurídico ou 0 Judiciário dar essa força, porque a cadeia não conserta. A cadeia piora.

(vfamiliar01)

\subsubsection{Categoria $h$ - Explica o papel da saúde em fornecer informações importantes}

A saúde pode também levar para as autoridades informações sobre o número de casos de violência aqui na região, que tipo de violência, a idade das pessoas que foram atendidas.

(vprofsaúde05) 


\subsubsection{Categoria $i$ - Explica o papel da saúde como uma somatória de esforços com} outras áreas

Eu acho que para se reduzir a violência, tem que haver uma somatória de esforços. Toda sociedade desenvolvida é calcada em cima de três fatores fundamentais que é saúde, educação e segurança. Se o estado não oferece à família condição digna de subsistência, então os pais não podem prover os filhos nas necessidades básicas de vitaminas, cálcio, proteínas; esta criança, no desenvolvimento mental dela já vai ser afetado, então não vai ter o desempenho escolar desejável, ela vai ter deficiências de aprendizado. Esta deficiência pode causar complexos, causar um certo complexo e um isolamento social. Este isolamento social pode levar à delinqüência. Então é isso, eu acho que um fator está ligado a outro. A sociedade desenvolvida ela tem que ter um sistema de saúde decente e no mínimo aplicável à grande maioria da população, a educação também tem que ser feita de uma forma consciente, e acessivel a todos. A educação, se ela for bem desenvolvida, depois da saúde, vai gerar menos violência, pois a pessoa mais esclarecida ela vai ser menos propensa a praticar ou receber uma violência, vai estar mais bem preparada para a vida. A par de tudo isso, o estado tem que oferecer condições de trabalho, lazer, tem que haver mais vontade política, existe muita demagogia, muita hipocrisia por parte do estado. Toda esta somatória de fatores enfim, levam à crescente violência que estamos vendo aí. Isto aliado à impunidade, a esta inversão total de valores. Se fala muito em direitos humanos, mas o que vemos aí é a apologia dos direitos humanos para bandido. Você não vê a apologia dos direitos humanos para uma vítima de latrocínio. Eu nunca vi um padre, destes dos direitos humanos ir rezar uma missa de corpo presente para a familia e oferecer ajuda para a viúva e aos filhos. Só se fala em bandido. Uma inversão total de valores, um caos social que aí está, aliado a todos estes fatores negativos. Então, o que gera a violência, o que aumenta a violência são todos estes fatores conjugados de forma negativa. Então eu acho que principalmente o que tem que haver é vontade política. Nós vemos aí um monte de políticos demagogos, hipócritas. Na hora de campanha eles: "a violência, a segurança" fazem aquela apologia toda mas nós não vemos nada de concreto. Nós vemos leis, este país é o país que mais fabrica leis no mundo inteiro, e onde menos se cumpre. A maioria das leis aqui é feita para a Escandinávia, para a Suiça, para a Suécia; não é aplicável neste pais onde não existe ainda preparo intelectual, não existe cultura que faça o povo aceitar este tipo de lei. Então é o pais onde mais se fabrica leis e onde menos se cumpre, onde mais se vê impunidade. Estes traficantes têm o poder econômico. Eles provocam esta situação e o estado se sente impotente diante disso. Tudo isso vai gerando descrédito nas instituições no poder público, o que é mais um fator a gerar violência. O que esta sociedade precisa entender e acordar é que tudo isso é um problema total, é uma globalização dos problemas que geram a violência. Não adianta atacar um problema estanque: o menor carente, o menor abandonado, o menor delinqüente. Ele é um 
produto do meio, da própria sociedade. Então a sociedade tem que entender que tem que trabalhar como um todo. Não existem coisas estanques na sociedade. Os fatores que geram violência são todos estes e mais alguns que podem ter me fugido agora. Onde não há saúde, não há educação, não há segurança, não há trabalho, não há lazer; há impunidade, as leis são obsoletas, Há uma inversão de valores, não existem condições dignas de vida, isto gera violência e aliado a tudo isto essa corrupção política que nós vemos ai a todo momento, tudo isso gera violência. Então a polícia paga por todos estes fatores tudo cai em cima da polícia. A polícia é ineficiente. A polícia tem seus defeitos? Tem suas mazelas? Suas carências? Isto é óbvio que tem. A polícia é feita por seres humanos e os seres humanos são carentes e falhos por natureza. Mas a sociedade é uma só. Nós todos somos a sociedade. Eu acho que tem que haver principalmente uma conscientização coletiva da sociedade destes fatores que têm que ser combatidos como um todo. Não de forma esporádica ou estanque ou isolada. Tem que haver uma consciência coletiva e se combater isso de uma forma concreta e eficaz. Na minha opinião, os maiores problemas deste país hoje chamase classe política.

(vfopinião03)

Apesar de vindo de um único sujeito, este discurso trabalha a tendência de projetos bem sucedidos que é o da somatória de esforços entre diversos atores, potencializando esforços e recursos.

\subsubsection{0 categoria $j$ - Explica que a saúde não está cumprindo o seu papel}

O serviço de saúde é tão quebrado que a gente percebe pelas pessoas que vêm aqui. Elas não vêm acreditando no serviço da saúde, já começa por aí. Então, muitas vezes vem aqui e querem que o médico "dê uma olhada". Se a pessoa por acaso for privilegiada e tiver um convênio já chega dizendo que tem o convênio e que quer só o primeiro atendimento para ir para 0 convênio. Já é uma prova de que não está acreditando no serviço da saúde, que não é só aqui, é em todo o país. Às vezes esse serviço de saúde não está mesmo atendendo nas coisas mais banais, está deixando a desejar. Aqui no nosso local de trabalho, acontece muita falta de médico. Eu falo aqui porque aqui é o exemplo que eu posso dar mais forte. As pessoas já vêm achando que não vai sequer nem ter 0 atendimento, por saber que muitas vezes nem o médico tem aqui no local. Então vê que começa por um fato muito sério. Faltar até médico, pelo amor de Deus. Realmente essa saúde nossa está muito quebrada. A pessoa já vem vindo de violência lá fora, chega aqui e encontra uma saúde violentada? Porque não ter médico num PS como às vezes acontece aqui, eu acho um ponto muito crucial.

(vfprofsaúde04) 
4.2.7 Sétima Pergunta - Você gostaria de falar mais alguma coisa sobre a violência? Fique à vontade para fazer os comentários que desejar.

\begin{tabular}{|cl}
\hline Categoria & \multicolumn{1}{c}{ Idéia Central } \\
A & Pelo papel do governo \\
B & Condições sócio-econômicas \\
C & Papel da segurança pública \\
D & Sem explicações \\
E & Pela sociedade contemporânea \\
F & Falta de Deus \\
G & Liderança do tráfico \\
H & Quebra das redes sociais \\
I & Falta de expectativa do jovem \\
J & Mau atendimento da saúde \\
K & Ação do líder do tráfico
\end{tabular}

\subsubsection{Categoria a - Explica a violência pelo papel do governo.}

Eu queria tanto que melhorassem as coisas, que as pessoas deixassem tanto a violência, que entrasse uma pessoa que trabalhasse melhor, que dirigisse as coisas melhor. Eles que podem fazer. O governo Não somos nós. Você vê que o governo entra e fala que vai fazer e acontecer $e$ acaba não fazendo, todo mundo tem a solução, a fórmula de resolver, só que acaba que ninguém consegue resolver. Eu acho que deveria ter mais incentivo à educação, incentivo aos jovens, que são o futuro do nosso País. Com um pouquinho de boa vontade política e ajuda à população mais carente. Eu acho que a violência já vem lá de cima. Dos governantes, que não ajudam nada, porque a gente vê as manchetes nos jornais; é deputado de tal que roubou tantos milhões, é presidente que desviou tantos milhões, é governador. Então isso vai gerando o que? Que as pessoas, que o povo se revolte e já gera uma violência em si. Porque a pessoa já ficá revoltada e fala - eles querem cobrar de nós o que? Está mostrando aí todo dia que eles que roubam, que faz isso, que faz aquilo; então porque a gente não vai roubar? Não vai matar? A questão da violência está ficando até sem comentários. Essa violência está ficando assim tão sem controle, a gente está vivendo tão assustado que não dá nem para imaginar o que poderia combater um pouquinho mais ou solucionar um pouco mais essa violência. Porque chega a um ponto que as pessoas vêem que precisa mudar a atitude, a gente percebe que tem jovens que estão caminhando para a questão do 
crime, ele tenta mudar a atitude e o que é que ele depara? Se ele pára na frente da televisão para assistir o jornal, os colarinhos brancos só fazem besteira. A gente vê todo dia no jornal cada história mais escandalosa que outra. Então eu acho que isso influencia muito mal para o jovem. Isso ai é uma coisa até sem remédio. Entre nós, cá na baixa sociedade, uma solução deveria vir da alta, porque eu acho que tem que ter o exemplo. $O$ país está abandonado, sem um bom dirigente, com tanto escândalo, em toda área quase. É o que todo mundo sabe, a violência se origina da marginalização desse povo da periferia das grandes cidades. Não tem oportunidade de estudo, de trabalho, eles se envolvem com o que está mais próximo deles, que é o tráfico de drogas, e ai eles vão para esse submundo do crime. É, seria um trabalho de muito profissional para resgatar essas pessoas da violência. Então o governo, as organizações sociais, todos, inclusive também a área de saúde, a área de saúde pode dar a sua contribuição, mas na parte educacional. A violência perdeu o controle. Sai Presidente, entra Presidente e promete, promete e nada.

(vfamiliar02, vfamiliar03, vfamiliar07, vfopinião06, vprotagonista05vprofsaúde05)

\subsubsection{Categoria b - Explica a violência pelas condições sócio-econômicas}

Esse negócio de menor não pode trabalhar de cobrador de perua, menor não pode fazer isso, não poder fazer aquilo. O menor quer ter as coisas, nós somos pais, não é tudo que os pais podem dar, então, eles vão para que lado? O lado fácil. Aí encontra um, como o meu filho encontrou. "Não fulano, vamos ali porque ali a gente vai roubar um carro, ali vai sair dinheiro, nós vamos em 10 e vamos ver o tanto que sai lá, dá um tanto para cada um". E dali começa um, infiltra um, um fazendo a cabeça do outro e ali vira uma bola de neve. E acaba aonde? No cemitério ou na cadeia. Por que eu estou trabalhando? Para ocupar a minha cabeça. Quer dizer, se eu ficar parada a cabeça gira, eu estando trabalhando eu estou concentrada naquele serviço, eu estou fazendo aquela roupa, chegou a hora de eu vir embora eu venho embora, eu cumpri a minha obrigação, chega o fim do mês o salário está ai. Agora, cabeça vazia é oficina do diabo. Perdi dois filhos na violência. Se tivesse os dois trabalhando eu garanto para a senhora que não. Quer dizer que pela violência e o desemprego eu perdi dois filhos. A violência é gerada por diversos fatores como a concentração de renda, má distribuição de renda. São três fatores que mais geram violência: má vontade política, Concentração de riquezas e má distribuição de rendas. Os fatores são todos políticos e sociais. Enquanto não se combater estes fatores de uma forma realmente eficaz, a violência nunca vai reduzir. Eu acho que a violência também tem a ver com a questão de serviço, porque se o prefeito que entra em cada município do Brasil, o prefeito chegasse e fizesse o negócio certo, o Brasil iria pra frente; gerasse empregos em firmas. O desemprego foi a causa de dar mais a força para violência. Nós vimos hoje quantas familias não puderam comprar um ovinho de páscoa, nem um bombonzinho, porque não tem praticamente o arroz para comer. $E$ esses 
jovens, não sentem vontade? Adolescente, criança. $O$ pai bate, bate, bate num canto e não encontra trabalho. Quer violência maior que a de um homem ficar mendigando, pedindo, catando até as latinhas, os jornais. Estão brigando para catar papelão, porque eles estão necessitando daquilo, isso é a violência maior que nós temos, então eu acho que nós precisa não é da Fome Zero,é desemprego zero. Que não dê nenhum centavo de aumento para o salário mínimo, se não der para dar, não dê não, mas que se dê trabalho. Abaixa esse juro para os empresários poderem trabalhar, porque, quando eu derrubo o meu patrão, eu derrubei eu muito primeiro. Porque ninguém agüenta mais pagar juro. Então, o que nós precisamos é de produção. Então eu acho que nós precisamos de emprego.

(vfamiliar01, vfamiliar03, vfopinião03,vprotagonista03)

\subsubsection{Categoria c - Explica a violência pelo papel da segurança pública}

Eu acho que tinha que ter mais polícia nas ruas. Minha irmã morreu aqui em cima, no terminal de ônibus, três horas da madrugada, três e meia. Se tivesse passando uma viatura na hora, não tinha salvado ela? Aqui nesse lugar a gente vê polícia quando acontece um tiroteio, daí viatura sobe, viatura desce, mas pelo contrário não, Aqui na minha rua é raro eu ver uma viatura passando. Eu acho que os policiais deveriam ter mais treinamento, por que hoje em dia quantas $e$ quantas pessoas não morreram por engano? A polícia matou porque achou que era um bandido. Eu acho que eles tinham que ter mais treinamento, e eles não têm. Isso dai é muita violência, muita mesmo. Eu acho que o governo não faz nada para melhorar, porque eu não vejo melhora; você vai numa delegacia, você é tratada mal, eles mal olham para você. Falta muito treinamento, falta de educação. Falta muita coisa. Porque o certo seria a polícia educar, ensinar e educar. Eles pegam uns meninos que não tem nada a ver, os moleques que nem roubam, dão tapa nas orelhas dos meninos, bate, dá cacetada; os meninos se revoltam e começam a ficar revoltados com a polícia, vê a policia e já começa a xingar, depois apanha, perde a moral e começa a roubar pra fazer vingança com a polícia. Do jeito que nós estamos é difícil até você falar na violência, porque a violência não está só na rua, está em casa, está na rua, está em todo lugar, e eu acho difícil combater. Por exemplo, à noite você está em casa, você não tem segurança em casa, está na rua não tem segurança na rua, você vai para um médico, você não sabe se de repente você vai ser morto lá dentro. As pessoas têm medo de falar, de denunciar, porque tem muitas vezes que o próprio polícia chega no local e diz, "olha, foi fulano que te caguetou, foi sicrano que te caguetou". Então, a pessoa que vê o crime, como não aconteceu comigo, lá na minha família, ela não cagueta; ela toma as dores ou ela denuncia quando é alguém da familia, mas ela toma com receio. Na periferia o crime está acontecendo com mais proporção porque a pessoa que relata, não tem segurança. Porque não confia que o que ela está passando via ficar ali gravado. Alguém teve acesso àquilo. Será que ela pode confiar na pessoa que a recebeu? Então, ficam com medo de 
denunciar. Têm medo de falar e sobrar. Eu acho que a grande causa da violência é a insegurança da população em denunciar. A violência começa da polícia; pra conseguir as drogas, eu comprava da policia civil; pra conseguir as armas, eu conseguia da policia militar, a violência começa das policias. Eu dou $R \$ 1500,00$ por mês pra civil e $R \$ 1500,00$ pra militar. Toda noite aqui chega dez a quinze viaturas; cada uma delas pega de dez a quinze papéis pra cheirar; como é que trabalha cheirado? Hoje a violência começa com a polícia, ela faz hoje vagabundo ficar revoltado. Eu tenho dó de quem eles pegam na rua, porque eles trabalham muito louco, bate na cara, chuta na barriga, judia dos coitados dos moleques; quando encontra criminoso é só: me dá $R \$ 10.000,00, R \$$ $50.000,00$ o quanto o cara tiver no bolso. Pega um pai de família, o coitado não tem um real no bolso, quebra no meio, arrasta pra quebradinha lá e dá uns três tiros no cara só porque ele não tem um tostão. A violência começa dos próprios policiais, não é pela sociedade, a sociedade tem medo deles, eu mesmo tenho medo deles; é mais fácil você ser ajudado por um vagabundo do que pela polícia, porque vagabundo está todo dia na sua área. A policia vem, dá uma olhadinha e depois some; vagabundo fica ali todo dia. A polícia se souber que alguém morreu ali ou que foi assaltado, pra chegar uma viatura aqui demora; se falar que tem um acerto vem um monte de viaturas ai pra buscar dinheiro. A gente fica com medo mesmo, toda a sociedade aqui tem medo dos próprios policiais. Se vagabundo estiver na rua, eles vivem bem, porque é acerto de $R \$$ $5.000,00 R \$ 10.000,00 R \$ 3.000,00$. Quer dizer, a violência já é gerada também mais por eles. Igual você vê, às vezes os policiais abordam certas pessoas e já vão batendo, isso é certo? Isso não é correto. Eles estão ali para corrigir e dar exemplo. Se eles não querem violência, eles não têm que ser violentos. Quando teve o massacre do Carandiru, eu estava lá fazia 4 anos já. Foi em 92, e eu cheguei lá no começo de 89. Eu pensei que ia morrer. Aquele filme do Carandiru, tem muita besteira, muita coisa ali é mentira. Não tinha nenhuma arma; é igual os Direitos Humanos falaram, era só desligar a água, desligar a luz. Não tem comida, não tem nada, eles iam se render. Não tinha um funcionário com ninguém, era só preso rebelado, e eles entram e matam mais de 200 pessoas. 111 foi o que familia correu atrás e reclamou o morto. $E$ os que foram enterrados como indigente? A gente viu vários sair em caminhão de lixo, jogado na traseira de viatura e foi sumido. Quando liberaram para fazer a faxina no pavilhão, pra desinfetar, para fazer a recontagem, foi achado corpos no elevador, isso depois que já tinha saido a listagem de 111. Então já vem errado de muita coisa, o cara bota uma arma na mão e ele se sente o dono da situação. Eu procuro falar para eles que tudo isso é besteira, tudo isso é ilusão. Quando você cai na realidade, muitas vezes é tarde. Muitas vezes não tem volta.

(vfamiliar04, vfopinião02, vprotagonista01,vprotagonista02,vprotagonista04,vprotagonista05) 


\subsubsection{Categoria d - Não tem explicação}

Hoje estou sentindo muito sufocada. Eu não tenho explicação para a violência. $A$ única coisa que eu posso falar é pedir paz, as pessoas tem que olhar um pouquinho o ser humano, olhar para si mesmo, para a sua família e o que não quer para si, não querer para os outros. A única coisa que eu peço é paz. Eu não uso de violência com ninguém, eu não desejo mal para ninguém e eu acho que se todo mundo pensasse assim, esse mundo era uma maravilha. As pessoas têm que pensar bem antes de sair tirando as vidas por aí, porque é uma coisa muito séria, vida ninguém tem o direito de tirar. Então eu peço paz. A única coisa que eu peço é isso. Eu não sei se é importante o que eu tenho para falar, mas é o que eu penso e o que eu sinto.

(vfamiliar05, vfamiliar06, vfamiliar08)

\subsubsection{Categoria e - Explica a violência pela sociedade contemporânea}

É falta de segurança, é falta de educação, é falta de amor ao próximo, é falta de família. $O$ assunto é complexo, merece uma conferência só sobre ele, tem aspectos muito importantes e um deles é trabalhar a pessoa como um todo. Isso eu tomo como religião, como saúde, como política. Todos os âmbitos da sociedade. Nós estamos assim um pouco viciados a tratar as pessoas só em alguns aspectos. Precisamos repensar esta questão como um todo. $O$ ser humano como um ser complexo e que merece desdobramentos. Eu acho que a sociedade de consumo é um instrumento que leva, sobretudo o jovem à criminalidade. O que se prega hoje na mídia, na sociedade contemporânea é que as pessoas para serem incluidas na sociedade têm que ter o carro do ano, o relógio moderno, a roupa de grife, e isso é colocado pela mídia, pela sociedade de consumo que nós vivemos. Estão perdendo a dimensão humana das ações, sobretudo as públicas. Você abre os jornais e só se discute a taxa de juros, só discute economia, a importação, mas os problemas sociais... O que as pessoas também não conseguem ver no cotidiano é que elas são vítimas da violência no dia a dia e não percebem. Quem não tem o transporte adequado para chegar ao trabalho, isso não deixa de ser uma violência contra o cidadão, que tem direito de ir e vir. Quando ele não tem condição, não tem saneamento básico é um instrumento da violência, quando ele é vítima da especulação imobiliária e compra um terreno que foi valorizado através de um investimento público, ele também é alvo da violência. Este tipo de violência, eu acho que a sociedade ainda não se ateve. Quando o cidadão vai lá no pronto socorro e ele é atendido por uma pessoa de segunda categoria, ele está sendo vítima da violência, não é só a violência da criminalidade, mas uma violência que a própria sociedade impõe sobretudo aos mais necessitados, é uma exclusão e isso se dá de forma silenciosa e as pessoas não percebem. Acham que a violência é a criminalidade, mas a violência não é só a criminalidade. Isso me incomoda muito. As 
pessoas ainda não perceberam, mas isso é colocado de forma ideológica; sempre foi assim, não se tem vontade de mudar isso. Acho que esse tema é muito pouco abordado. As pessoas têm um pouco de receio de mexer nisso. Está enraizado na cultura da sociedade contemporânea, sobretudo aqui no ocidente. Só uma mudança cultural e de educação para mudar, para abrir os olhos desta geração que está porvir. As pessoas precisam começar a ser alertadas para isso. $O$ mundo não é assim, o mundo não é dividido entre ricos e pobres, é dividido porque a sociedade assim coloca, mas a pessoa não é pobre porque $D$ 'us quer que seja pobre. Ela é pobre em função de uma série de atores que atuam em uma sociedade. Agora, vamos pegar o Brasil. Nós ficamos muito tempo sob a égide da ditadura. As pessoas não podiam se pronunciar, tivemos o desmonte do sistema educacional, não tinha um projeto de país, Tudo isso hoje é uma conseqüência, conseqüência de uma série de desmontes durante anos. Será que no Jacira a violência algum dia foi menor do que é hoje? Será que hoje a violência e a criminalidade não estão em pauta porque chegou na classe média? Se não chegasse na classe média, dos formadores de opinião, as pessoas não estariam preocupadas com a violência. Hoje ela consta hoje como prioridade de governo, de aspiração da população porque chegou na classe média. Enquanto o cidadão estava lá no Jacira morrendo, sem escola, sem um médico, poucos estavam preocupados com isso, mesmo a mídia. Hoje que chegou onde chegou, no Jardins, chegou em Higienópolis, na Paulista, em uma série de lugares, que incomoda aos formadores de opinião, classe média, mídia, imprensa, está na pauta de governo.

(vfopinião04, vfopinião05vprofsaúde04,vprofsaúde06)

\subsubsection{Categoria $f$ - Explica a violência pela falta de Deus}

Eu acho que está faltando Deus. Eu acho que está faltando muito Deus. Eu creio que a violência de um modo geral está ligada a falta de religiosidade, a falta do divino, acho que a falta de Deus está muito ligada a essa violência. O povo hoje está até um pouco descrente do que eu, por exemplo, aprendi de criança sobre Deus. Isso que eu aprendi foi a base para que eu não fizesse algo violento. A escola tem incidência direta no futuro de uma sociedade, violenta ou não. $\mathrm{Na}$ educação deveria se tratar desta questão mais profundamente considerando vários aspectos. Se a gente pensar na sociedade que estamos criando, nós caminhamos cada vez mais para a violência. Um exemplo: você pode ficar justificando que no passado a bíblia, a palavra de D'us foi usada para fazer violência. Mas isso seria só julgar o passado. Na escola se tirou a bíblia. Não se pode ler mais a bíblia porque tem a questão das religiões. Tem que se respeitar todas e em nome deste respeito a todas não se fala de nenhuma ou não se fala daquilo que é comum a todas. Até pouco tempo o estado de São Paulo era a expressão disso. Não tinha uma educação religiosa. Se tirou a bíblia da escola e se alguém tenta ler é logo rechaçado. E é a biblia que fala de amor, respeito ao próximo, de não violência, de caridade.

(vfopinião01, vfopinião04) 


\subsubsection{Categoria g - Explica a violência pela liderança do tráfico}

Com tanto jovem morrendo hoje,é por causa da ganância. O criminoso hoje não tem vontade de conseguir alguma coisa, hoje ele tem mais o olho gordo nas coisas do outro do que ele mesmo conseguir o seu; isso está sendo a violência. Antigamente você entrava no crime e conseguia uma moto, um carro, um apartamento... hoje não, o cara entrou no crime matou dois, três então ai ele está sendo criminoso, então quanto mais ele matando mais ele vai tendo nome. Hoje em dia a violência está ficando alta e é o velho olho gordo, porque ninguém quer dividir o pão, quer comer sempre o pão sozinho. Tem um trafico correndo, eles querem matar você, que já esta no tráfico há mili ano pra tomar seu lugar. O crime está começando logo da classe $A$ não dos pobres; o crime está começando na classe média, que o crack está desandado na classe media também. Antigamente era só na favela, você não via na classe média, hoje já mudou, os pobres não estão usando mais, só os ricos estão usando. Dos criminosos que eu conheço, eu sou o mais velho; dos moleques que estão subindo hoje, ninguém pensa em te ajudar que é mais velho pra conseguir o cargo junto com você amanhã ou depois, eles pensam em matar você pra tomar o seu lugar; se fosse pra eu entrar no crime hoje eu não entrava, preferia ser um pai de família. Não tenho coragem de colocar um revólver na cinta ir ali e roubar $R \$ 500,00, R \$ 1.000,00$. Se você vai preso, por menos de $R \$ 10.000,00$ você não sai. O assalto à mão armada, se você for preso, você precisa ter ao menos $R \$ 10.000,00$ pra trabalhar no seu caso, pra pagar advogado, para pagar uma madeira lá para as polícias deixarem você em paz. Você vai sofrer na cadeia; 121 é homicídio, no mínimo é 15 anos, 15 anos o cara pega por um carro, por uma moto. Hoje os caras não sabem o que é o crime, matar todo mundo mata, roubar todo mundo rouba, quero ver a hora que for preso e falar para o juiz: juiz eu matei, juiz eu roubei; ai o juiz fala toma dez anos, quando chega lá dentro fica chorando, lá fora não tem um real. Obrigado ir o pai e a mãe trabalhar pra visitar na cadeia, às vezes a passagem custa $R \$ 100,00$ e a mãe é obrigada a tirar de dentro de casa pra ir ver o preso e esse cara fala que é ladrão, não conseguiu nada na rua, só atrasou os outros, e na cadeia fala que é ladrão, é por isso que o crime esta um podridão em todo canto. Se fosse pra eu roubar hoje, mudava de idéia, não vale a pena ser criminoso não, porque tem muita policia na rua e tudo que você consegue no crime você perde de novo. Olho gordo não deixa você crescer, o pessoal pensa em matar alguém pra criar nome, pensa que o nome é tudo. Quem tem que criar nome é cantor pra vender $C D$. Na vagabundagem tem que ter dinheiro pra quando sujar ele sair fora. Estou largando de mão. Posso viver com um cesta básica mas se eu dormir, durmo sossegado, porque se eu ficar no crime eu tenho que matar um bocado; ai eu vou ganhar determinação e fico na policia. Mas não, deixa eles se destruírem por eles mesmo. Eu por mim matava todos os pilantras. Isso não é violência porque os pilantras são um câncer da sociedade; já pensou, o cara entra na sua casa e leva sua batedeira, seus negócios que você suou pra comprar, e vender a preço de banana e comprar duas ou três pedras pra fumar. Um cara desse merece ficar 
na sociedade? Ir pra cadeia ele não pode, porque ele vai ganhar um ritmo melhor dentro da cadeia e quando ele sair vai ser o maior bandidão, então é melhor matar, porque matou pela raiz, cortou pela raiz já era. Ladrão hoje não pensa em construir um patrimônio, ele só pensa em destruir com a droga, eles só pensam em consumir a droga. $O$ que está destruindo hoje a sociedade e as polícias é a droga; é a coca e o crack. Hoje o cabeção não usa mais cocaína, não usa mais crack, antes você pegava $1 \mathrm{~kg}$ de base e fazia um $\mathrm{kg}$ de crack, hoje você pega 30 grs de base e $50 \mathrm{grs}$ de pó Royal, 30 grs de cimento é tudo misturado e vai comendo as células da mente dele, não tem célula mais. A questão da violência é que cada dia está pior, não vai melhorar. A pessoa falar que vai amanhã ou depois, entra um político, sai outro, vai melhorar, faz um projeto, não sei o que, mas a tendência é só ficar pior. Principalmente, como eu já falei, aqui na periferia, essa molecada que morre ai é traficante, o cara de 20 ou 30 anos, mas tem moleque que faz segurança nas bocas, tem moleque de 10, 15 anos, 12 anos, tudo envolvido já. Então morre o chefe, acaba ficando outro no lugar. Então é difícil, fica difícil, se envolve tudo, se envolve tudo mesmo, principalmente a situação financeira da família. O pessoal fala que não, que vai melhorar, mas não melhora. Cada dia está pior mesmo. O principal é que a maioria que se envolveu, estão mortos, e quem está substituindo sempre é um parente ou alguém que trabalhava ali, alguém da familia, ou um moleque. A violência está aumentando cada vez mais, principalmente para a gente que mora aqui em periferia Esse tal de PCC pra cá agora que não tinha. Esse negócio de PCC que começou, agora está concluído. Agora tem um pessoal do PCC que já mora por aqui mesmo, já estão dominando tudo. Aí é aquele famoso ditado: "cobra engolindo cobra mesmo". Aqueles que são pequenos acabam engolidos.

(vprotagonista04,vprofsaúde01)

\subsubsection{Categoria $h$ - Explica a violência pela quebra das redes sociais}

Eu acho que uma das grandes causas é a familia, a familia desestruturou. A nossa família hoje não é mais aquela familia tradicional: mãe, pai, filho. Que em casa a mãe tem uma vida mais presente, o pai tem uma vida presente. Muitas familias a gente sabe que não tem pai, quando tem pai é 3 ou 4 pais, 3 avós - eu escuto histórias de crianças falarem. Como 3 avós, 4 avós? Porque a mãe já separou uma vez, separou a segunda, a terceira. A familia é o berço de tudo. A família é tudo. Se ela não tem uma estrutura familiar, ela não vai ter como sair da violência, ela desde a própria casa ela já está trazendo a violência. Ela já está presenciando a violência, então, na escola, na rua, a vida que ela for levar, social, tudo. A gente que está na educação percebe muito isso, a família largou. Os pais saem para trabalhar, então joga na escola, a escola é família, é tudo, então o que acontece? Os professores, não estão estruturados para isso. É psicólogo, é mãe, é enfermeiro, é tudo, sabe? Está jogando tudo para a sociedade; uma coisa que é do berço, é da familia, e se aquilo lá não está estruturado vai refletir no futuro, que é o futuro social, quando ele 
for para o trabalho, quando ele for para o mundo. A familia é o berço de tudo e como a família está desestruturada, o resto não vai ter jeito. Mas a gente tem esperança através de muita perseverança, cada um fazendo uma parte, a saúde fazendo a sua parte, a educação, a escola fazendo outra, a gente pode resgatar alguns, mas a gente sabe que a grande maioria não. $\mathrm{Na}$ escola que eu trabalho, eu tenho adolescentes que falam que vão mudar, mas a gente vê a vida, como vai mudar? Porque o cara acabou de sair da cadeia - não tem uma estrutura, não tem uma família estruturada, não tem emprego, e se o rapaz não tem emprego, aonde que ele vai arrumar o dinheiro para o sapato, para a comida, para ajudar em casa até e tudo isso? É roubando, matando. Então a gente sabe que a realidade é outra, na hora de pegar firme mesmo dizer assim - vai lá que eu vou te dar o emprego - não existe isso. É muito difícil, se ele não tem essa estrutura lá, na família, eu volto sempre falando na família, ele não vai ter como ele sair do mundo do crime, porque ele não tem outro respaldo, ele não tem onde se engajar, onde ele possa se embasar para viver. Eu achava que as pessoas, como governantes, de um Estado, de um Município, deveriam orientar mais a população, esclarecer mais. Porque tem pessoas que o que eles sabem eles guardam só pra si, ele não passa para o próximo.Por exemplo, na área da saúde tem pessoas, tem direções que querem só para eles. Às vezes a pessoa tem como ajudar mas não faz por motivo político, por achar que pode se prejudicar amanhã ou depois; eles não pensam muito na população, no próximo. Eu acho assim que o ser humano em si, desde lá de cima, até o mais baixo, tem que ser mais humilde e ser mais próximo aos outros, ajudar o próximo. As igrejas têm que se ajudar em tudo isso, indiferente de qual seja. todas elas, todas, têm que se ajudar. Chamar as familias e resgatar uma coisa que está degradada, a familia. Ninguém mais senta na mesa, conta uma estória na hora do almoço, não conta uma coisa, não conta uma piada. Se nós quisermos acabar com a violência, diminuir muito, porque acabar, nós não vamos acabar, porque desde que o mundo foi feito que teve a violência. Nós temos que resgatar a familia, valorizar muito a familia. Se a gente tiver um filho, uma filha que estiver no caminho errado, a gente pode começar a olhar onde que a gente também falha. A gente também falha com os filhos, às vezes a gente quer trazer no cabresto muito apertado e o cabresto acaba e estoura. Tem que haver um diálogo entre o pai e o filho, a mãe e o filho e juntar a família. O casamento, está meio caindo aos pedaços. $O$ casamento acaba, a mulher vai encontrar outro homem e o marido vai encontrar outra esposa, $e$ os filhos encontram outro pai? Pra nós acabarmos com a violência, faz falta o aumento de policia? Faz. A polícia esta desfraldada, mas as familias precisam ocupar os lugares que os traficantes estão ocupando. Quando nós ensinamos uma criança, a criança aprende, e a criança é a melhor multiplicadora da paz, não adianta fechar grades, botar grade de todo lado, eles pegam no portão. Se a gente não resgata nem a familia da gente, como é que a gente vai resgatar fora de casa, se a gente entra dentro de casa e só briga; briga a mulher, briga os filhos, é uma contenda; cada um quer só pra si, não sabe dividir o pouco que ganha. Numa família, quando tem um desempregado cada um ajuda um pouquinho aquele até que ele se coloque num trabalho. Ele não trabalha porque não quer, ele sai pra rua, acha um amigo que paga um copo de bebida. Hoje ele bebe, amanhã ele 
já pagou um trago, depois de amanhã o outro já convida: vamos fazer um manero ai? Ele vai, ele faz o primeiro e não acontece nada, depois ele faz o terceiro e o quarto e depois ele vira um profissional, mas a raíz dele foi arrancada lá dentro da familia não foi na rua que ele se perdeu. Quando a filha pergunta: mãe assim, assim, assim, a mãe às vezes não tem tempo de responder, mas deve procurar uma hora correndo pra dar uma reposta, contar pra filha como é que ela começou a mocidade dela, como é que ela foi começando o caminhar de adolescente pra mocinha, contar para o filho, pedir ao pai para conversar com o filho. Confraternização no final do ano, no aniversario de cada um; muitas familias não fazem mais isso, não se reúnem, não se juntam na rua, um é mais rico, outro é mais pobre, outro é mais ou menos, e vão se juntando, ou mesmo no dia de uma precisão. Desta forma a violência vai diminuir muito e muito, porque um vai olhar pelo outro. Outra coisa que está faltando muito nas familias, é ensinar a criança o caminho de Deus, ensinar que existe Deus. um fato que origina também a violência são as familias desestruturadas, acho quer é o principal, onde começa tudo, porque ai as crianças crescem sem parâmetro nenhum ou deixa com empregada também que não vai fazer o papel da mãe nem do pai, ou deixa com a avó, deixa com a tia ou com irmão mais velho e todas essas situações deixam com que a criança cresça sem ser cobrada de nada. A criança quando fica muito largada é como se ela tivesse na frente da TV, ela faz o que quer e pra ela vai ser aquilo a verdade; causa muitos problemas no futuro, ou ela vai crescer desorientada ou orientada por filmes e novelas, ou por coleguinhas e ai acaba fugindo do propósito familiar. Porque é a familia que dá base de reação, de estrutura, de educação. Outro aspecto da questão: Vem alguém dizendo: vamos passar na televisão filmes de violência. Alguém responde, mas isso prejudica o jovem, isto é um estímulo para a violência. Vem outro e : "não, isso é só uma fiç̧ão, não sei o que, não tem nada de conseqüência" e o que nós fazemos? Estamos convencidos que realmente não tem nenhum problema. Dai a pouco vêm distribuir revistas com homens, mulheres nus, desfilar os corpos nas revistas. Vem alguém da sociedade que é considerado conservador e critica, alguém já defende: Isso ai é só para ver, observar, não significa nada. Isso aí é só um passatempo, um lazer e assim por diante. Vamos dando várias desculpas para coisas que no fundo implica no seguinte: Não se tem limites. Nós estamos criando uma sociedade sem limites. Sociedade sem limites, violência sem limites. Então nós temos que repensar muita coisa na educação, sobretudo educação escolar, educação religiosa e a alegria da gente é ver muitas pessoas trabalhando neste sentido. Não podemos dizer que ninguém está fazendo nada porque muitos educadores tanto na área escolar como na religiosa que já deram passos adiante e repensaram a questão da educação religiosa, educação pública e assim por diante.

(vfamiliar01, vfopinião01, vfopinião04, vfopinião06, vprofsaúde02) 


\subsubsection{Categoria $i$ - Explica a violência pela falta de perspectiva dos jovens}

Eu acho que os jovens deveriam ter uma prioridade para eles ocuparem o próprio espaço deles. Não é só dar uma renda, fazer isso, isso e aquilo, uma renda bolsa; Se ele não trabalhar, não adianta. Ele tem que sentir o gosto de aprendizagem; cada dia mais para que ele possa sempre melhorar também. Onde começa mais a violência é nessa faixa etária de 7 a 14 anos, que a mãe tem que sair para trabalhar, os pais saem, é onde que já vai sendo influenciado pelo maior ou outras coisas para a perdição, que é o roubo, curtir as drogas Filhos com 12, 1314 anos, não vão arrumar emprego porque a sociedade não dá emprego pra eles, e aí os pais soltam na rua 0 que o filho virou? Bandido. Acho que deveria dar uma assistência melhor para a juventude, para os adolescentes: um estudo melhor, um conhecimento básico, um emprego pra cada um, que ganhasse pouquinho mas que tivesse o suficiente pra eles ganhar o dinheirinho deles. Se você cuidar do jovens você tem um futuro melhor. Minha prioridade seria educar a juventude, fazer uma reunião com os pais, conversar com os pais dos adolescentes, A juventude e carente, não pense que a juventude que anda nesse mundo de meu Deus não é carente. Eles vão para o roubo porque eles são carentes. De tudo: são carentes de emprego, carentes de pai e mãe, os pais separados, a mãe separada, a bebida que é um problema dentro de casa. Que perspectiva esse jovem pode ter, que exemplo ele está tendo, que esperança de futuro? Não se pode condenar só os jovens, não se pode condenar só os jovens, e essa violência fica sem solução, vista por esse lado. Porque aí a gente percebe que quem está começando, está construindo... esse jovem que está se formando, ele já está se formando contaminado. Por mais exemplo bom que ele tem em casa, ele fica pensando assim - ué, mas essa sociedade só paga imposto, só é cobrada, mil e uma responsabilidades. Eu ouvi do meu filho - você trabalha feito uma condenada e eu não vejo você construir nada, mamãe? Só que eu sou madura e sei que a vida é isso, mas vai pôr isso na cabeça dele? Só que até você chegar e mudar esse pensamento do jovem depois que ele já foi influenciado na esquina e até dentro da escola, fica difícil. Por melhor exemplo que ele tenha em casa dos pais. Feliz dos pais que o jovem mais tarde amadurece e tome outro rumo e não cai realmente para o crime. Porque na verdade eu acho que não pode só condenar os jovens. Eles só estão despreparados num país que está contaminado. Hoje a droga está envolvida com todos jovens. Jovem hoje em dia, de 15 a 20 anos, ou já experimentou ou usa droga. Um experimentou e não quis, por opção, outro está no mundo, fica viciado; outro está porque ele acha um meio de ganhar dinheiro. Ele é um avião de alguém. Eu acho que jovem hoje em dia, ainda mais a gente que tem comércio, a gente vê, o jovem hoje em dia é ligado a droga por opção. Por ser uma coisa que o jovem curte. Antigamente o jovem dançar o break era uma moda, hoje ele usar uma droga já é um conceito. É um vício que todos eles têm. E começa na escola. Conhece a droga, a bebida; com 15 anos já conhece a cocaína e aí começa a roubar. 
Muitas pessoas vão pela miséria e muitas pessoas vão pela influência, por não ter assim uma opinião de vida definida. Eu por ser novo na época, eu não tinha; achava que tudo era mil maravilhas e não era.

(vfopinião02, vprofsaúde03, vprofsaúde04,vprotagonista01,vprotagonista05)

\subsubsection{Categoria $j$ - Explica a violência pelo mau atendimento na saúde}

A saúde em geral, se tivesse um atendimento bom, que qualquer pessoa que chegasse ali não demorasse a atender. Não tivesse aquele preconceito porque tem, em todo canto tem preconceito. outro dia eu fui no posto de saúde e tive que fazer um barraco, não fiz barraco pra mim eu fiz barraco para os outros, se tem um funcionário no posto e ele vira para as pessoas na fila e fala: vocês vão ter que me aturar, não é por ai, porque se uma pessoa está armada ela atira, e se ela atira e a pessoa morre e como e que fica? Fiz pelos outros porque eu não agüentei a humilhação, então se em qualquer um dos postos de saúde nós tivéssemos um atendimento bom, de qualidade... A gente é discriminado por não ter convênio, porque se nós tivéssemos um bom convênio nós não precisariamos enfrentar o posto de saúde. Tem mãe que vai revoltada, tem pessoas que vai puxar a arma lá pra dentro, puxa arma e diz você vai me atender. As pessoas que ficam do outro lado do balcão, eles acham que são donos da situação, se eu tiver um padrinho lá eu sou bem atendido e se eu não tiver eu não sou bem atendida, isso eu acho uma vergonha, uma humilhação. agora uma pessoa que vai lá querer um remédio que não tem condição de comprar, já vai doente, já vai sem saber pelo menos se vai ser atendido, chega lá e quem está lá do outro lado do balcão, como foi que eu vi, fala: vocês vão ter que me aturar se quiser pegar remédio, isso não existe.

(vfopinião02)

\subsubsection{Categoria $k$ - Explica a violência pela ação do líder do tráfico}

Onde eu moro não está nem tendo muita violência, mas já aconteceu uma violência comigo de tomar tiro essas coisas, já tomei tiro e passei mais de um mês internado, $A$ violência aqui onde eu moro já foi mais avançada, hoje está mais calma. Eu acho que nem foi pelas polícias que mudou isso, eu acho que a pessoa que começa a acomodar esse negócio de banco essas coisas, eu acho que esse é um cara mais sério. Se ele souber que o cara está roubando um comerciante, ele vai atrás, se ele souber que o cara está matando uma pessoa por maldade ele vai atrás, se ele souber que alguém está roubando pai de família, ele vai atrás. Eu acho que mudou mesmo por causa desse cara que entrou agora, ele está mudando mesmo; ele é o cara que quer saber tudo certinho que est acontecendo,. Este natal gora mesmo, ele comprou uma Van cheia de panetone e distribuiu pra todo mundo, no natal ele fez a mesma coisa: distribuiu cesta básica pra 
todo mundo e agora ouvi falar que ele vai distribuir cesta básica pra todo mundo que está precisando também, eu acho que o que está mudando é isso; se fosse um cara mais ruim, não estava nem aí, deixava todo mundo fazer...E ai virava bagunça total, eu acho que esá mudando por isso, e muito. Igual na escola lá embaixo: todo mundo ia roubar cobre das molecada, e estava começando a mexer na escola. Ele ficou sabendo, descobriu quem eram as mães dos meninos $e$ foi de casa em casa falar com elas, e hoje ninguém mexe mais na escola, ninguém picha, ninguém quebra vidro, ninguém faz nada. É ele que comanda tudo. Pra dizer a verdade eu nem sei quem é, quem comanda mesmo não fica aqui, os outros é que trabalham pra ele.

(vprotagonista02)

\subsection{Estratégias de enfrentamento da violência}

A seguir apresentaremos algumas frases pinçadas dos DSC colhidos nas sete perguntas realizadas que representam sugestões ou propostas de enfrentamento do problema. Algumas indicam estratégias já utilizadas pela comunidade e que têm potencial para serem incorporadas às políticas públicas a serem implantadas.

$>$ Nós temos que ir para a rua, nós temos que conversar.

$>$ Trabalhar a população, educação.

$>$ Cabe a cada um de nós fazer um pouquinho.

$>$ Desarmamento

$>$ Segurança melhor

$>$ Ir para a praça, para as ruas

> Teria que primeiro corrigir, esse negócio de dizer que menor de idade não pode ir para cadeia

> Tem sempre que andar acompanhada

$>$ Punição maior

$>$ A lei valer para todos igualmente

> Boa vontade e interesse político para mudar a situação

$>$ Ter solidariedade

$>$ Ter mais união 
$>$ Leis mais severas

$>$ Ocupação do espaço pelo poder público

> Ampliar a informação em segurança

$>$ Estudar experiências de outros países

$>$ Combater a corrupção policial

> Dar oportunidade a quem já tem passagem policial

> Implantar controle de natalidade

> Proteger a criança da violência dos pais

$>$ Valorizar a harmonia familiar

$>$ Maior atenção dos pais aos filhos

$>$ Combate ao alcoolismo e uso de drogas

$>$ Recuperar o valor da fé, o divino

$>$ Melhorar a qualidade da educação

$>$ Diminuir a permissividade nas escolas

$>$ Combater o preconceito

$>$ Atuar de forma preventiva

$>$ Impor limites desde o convívio familiar

$>$ Recuperar a ordem

$>$ Pena de morte para certos crimes

$>$ Recuperar a legitimidade das instituições

> Maiores oportunidades de estudo e trabalho

$>$ Reduzir as taxas de juros

$>$ Melhor preparo da polícia

> Maior critério na seleção de policiais

$>$ Cultivar a paz

$>$ Entender as pessoas como um todo

> Repensar a sociedade de consumo

> Resgatar a dimensão humana nas políticas públicas

$>$ Maior atenção à violência institucional

$>$ Construir um projeto de país 
> Promover mudanças culturais que discutam a forma como a sociedade contemporânea está organizada

> Trabalhar de forma multisetorial

> Resgatar no jovem o sonho, projetos de vida futura

\section{Análise e Discussão}

Ao analisarmos os resultados obtidos no levantamento dos óbitos por homicídio em Itapecerica da Serra no ano de 2002, algumas considerações devem ser feitas. A utilização das duas fontes primárias distintas: Declaração de Óbito e Boletim de Ocorrência permitem a obtenção de dados mais completos, em especial no que diz respeito à caracterização do local de ocorrência.

Verifica-se nas Declarações de Óbito alguns problemas em seu preenchimento que dificultam a percepção de um panorama mais amplo deste evento. $O$ não preenchimento neste documento da definição de intencionalidade ou não já não o torna suficiente para análise dos homicídios exigindo do pesquisador que busque outras fontes de informação, além de exigir que busque também os casos classificados como de intencionalidade não determinada, que podem incluir casos na verdade decorrentes de homicídios. CASTRO et al, 2003 comenta a não existência, mesmo em países mais desenvolvidos de sistemas estatísticos de características ideais.

Em nosso estudo ficaram claras estas dificuldades. Dos 119 óbitos por homicídio referidos pela Fundação SEADE para o período analisado, apenas 92 foram estudados. Limitamos nosso estudo aos homicídios registrados no sistema SIM/MS notificados no núcleo de Informação da Secretaria Municipal de Saúde local. Retratam os residentes em Itapecerica da Serra, vítimas de homicídio ocorridos no território municipal. Ao levantarmos os boletins de ocorrência registrados na delegacia local como sendo de homicídio doloso, obtivemos 
número diferente que o colhido na fonte primária anteriormente citada. Excluímos aqueles em que o local de ocorrência foi "estabelecimento de saúde", cuja residência constava como ignorada ou em local diferente do município em estudo.

Esta exclusão se deve ao fato de ser esta cidade uma referência em atendimento à saúde de casos de maior complexidade, mesmo sendo esta referência informal.

Estes fatos por si só conduzem à necessidade de discutirmos a adoção de instrumentos de informação diferentes dos atualmente em uso, que permitam o estudo e determinação não apenas do risco de um residente em determinada região morrer por homicídio mas também qual o risco de ser vítima de homicídio em um determinado local, que poderia ser extrapolado como um indicador de violência.

GAWRYSZEWSKI (2002) aponta a necessidade de urgente implantação de um sistema de vigilância epidemiológica para os homicídios. Discute ainda que a utilização de dados provenientes de fontes distintas, "amplia o número de informações e para algumas variáveis agrega maior qualidade".

Nosso estudo mostrou ser acertado reunir dados do SIM/MS com aqueles provenientes da delegacia local através de seus boletins de ocorrência, visto que este último além de apontar a intencionalidade, define o local de ocorrência do evento que levou ao óbito permitindo a construção de um mapa de risco baseado não apenas na residência da vítima.

GAWRYSZEWSKI, KAHN e MELLO-JORGE (2005), cruzaram dados obtidos da Declaração de Óbito, com informações do Boletim de Ocorrência Policial e laudos de necropsia e conclui que a integração dos dados permite melhorar a qualidade da informação, contribuindo para a compreensão dos homicídios. Estes autores relatam existir experiência em Cali, Colômbia na 
utilização de sistema de vigilância dos homicídios que trabalha com a integração de informações de fontes já existentes. Referem também experiência recente de criação de sistema de informações para acompanhamento de mortes violentas nos Estados Unidos que também utilizam integração de dados de diversas fontes.

A esmagadora ocorrência de homicídios no sexo masculino é também observado em inúmeros estudos sobre o tema como o de GAWRYSZEWSKI e MELLO JORGE (2000); MINAYO e SOUZA (1993), SOUZA(1998), SOUZA(2005) entre muitos outros.

Homicídio é importante determinante no número de anos potencialmente perdidos, junto com acidentes automobilísticos.

Nosso levantamento de dados mostra ser a faixa etária mais atingida a de adolescentes e adultos jovens, o que é corroborado em outros estudos como os de LOPES et al (1996); BARATA, RIBEIRO e MORAES (1999), MELLO-JORGE e YUNES (2001); DRUMOND JÚNIOR (1999), BARROS, XIMENES e LIMA (2001).

A maior proporção de óbitos por homicídio em pessoas com até sete anos de estudo ratificam os resultados obtidos por outros autores que apontam relação entre baixa escolaridade e homicídio como RABELLO NETO, na cidade de Diadema em 2001.

Armas de fogo se constituem no instrumento mais comum para a perpetração do homicídio. PERES e SANTOS (2005) destacam o papel das armas de fogo como causa deste evento. Discutem também que, "na população feminina, a proporção de homicídios com outras causas supera aquelas da população geral e masculina".

GAWRYSZEWSKI, KAHN e MELLO-JORGE (2005), encontram diferença estatisticamente significativa na utilização de arma de fogo enquanto instrumento utilizado para o homicídio com proporções mais altas para o sexo masculino. 
Outro dado que este estudo nos traz é ser a utilização de arma de fogo aqui maior que nos Estados unidos no ano 2000, que foi de $64,7 \%$, a despeito da reconhecida questão cultural da posse de arma de fogo na sociedade americana.

A via pública, classificação em que se incluem bares, ruas, praças, terrenos baldios, campos de futebol e outros, foi o local de maior ocorrência dos homicídios.

Os mapas que mostram os óbitos por local de residência e de ocorrência são eloqüentes. No primeiro, temos o Jardim Jacira, Lagoa e Parque Paraíso como aqueles em que seus residentes estão mais expostos ao risco de ter homicídio como causa básica de sua morte.

Cabe aqui fazermos alguns comentários sobre estes bairros. O Jardim Jacira sofreu crescimento populacional acentuado nas décadas de 70 e 80 . Ao tempo deste estudo encontrava-se em sua terceira geração. Possui alta concentração demográfica.

O Parque Paraíso iniciado pelo desmembramento de uma fazenda que existia no local, cuja casa sede até hoje abriga os descendentes dos proprietários originais, tem o maior crescimento de sua população mais recente que a do Jardim Jacira. Também possui alta densidade demográfica.

O bairro da Lagoa é de formação mais antiga, caracterizando-se como uma transição entre o rural e de lazer e o urbano. Tem baixa densidade demográfica, o que amplifica a importância de cada caso de homicídio nele registrado.

Sofrem de mal semelhante, a sensação de não pertencimento de sua população, ainda às voltas com o lidar com a perda de seus antigos referenciais culturais, sociais e familiares e a construção de novos paradigmas e relações sociais. 
Ao estudarmos os óbitos por local de ocorrência, observamos como que um mergulho daqueles casos que no mapa anterior localizavam-se fora dos limites da cidade, para em especial as regiões do Potuverá e Valo Velho.

O aprofundamento do estudo desses casos nos conduz a ruas e estradas desertas existentes nessas regiões que permitem ser a vítima trazida para aí ser morta ou ser para cá trazida depois do crime cometido.

Ao analisarmos as idéias centrais dos discursos obtidos observamos que algumas se repetem com maior freqüência não apenas no número de entrevistados que a manifesta como nas questões em que é mencionada.

Vale lembrar que não é por aparecer apenas uma vez que uma idéia central é desprovida de importância, ao contrário, todas são importantes por serem representações do pensamento coletivo; algumas aparecem com maior força e presença.

Dentre as que mais se apresentam neste estudo destacamos os discursos presentes em diversas questões que explicam a violência por condições de vida desfavoráveis. Vários autores comentam o maior risco de violência em classes sociais menos favorecidas. BEATO FILHO (1999); MACEDO et al (2001); MINAYO(2003); CARDIA, ADORNO E POLETO(2003)

Esta constatação, válida para as vítimas da violência, perdem sua força quando observamos os perpetradores da violência. Fatos recentes, outros nem tantos e alguns estudos como o de COSTA (1999), mostram que condições sociais não são determinantes para o agressor. Apesar da vitimização estar distribuída, embora que de forma desigual em toda a sociedade, os agressores também o estão. É cada vez mais freqüente na imprensa denúncias de delinqüência provocada por jovens da classe média e alta. Em um dos discursos 
obtidos esta questão vem à tona confrontando ser o desemprego justificativa para a violência. ADORNO, BORDINI e LIMA(1999) discutem a participação de adolescentes na criminalidade urbana.

A questão do espaço/território como discutida por ROLNIK(1999) SANTOS,PORTO(1999) AKERMAN e BOSQUAT(1999); RIBEIRO e SANTOS JR.(2003) ; COSTA(1999) é muito citada, sendo entendido pelos entrevistados, que morar na periferia não é apenas uma questão geográfica; é estar afastado do centro das decisões políticas e econômicas. É estar apartado de condições de vida propiciadas pelo trabalho, lazer, transporte e outras determinadas pelo local de moradia. SAWAIA destaca a precariedade das moradias em condições subnormais ou como mais conhecidas, favelas "não significa uma vida comunitária, mas uma vida insegura, sob ameaça permanente de remoção, de acordo com a lógica dos especuladores e da administração pública". Destaca ainda que o aumento das moradias em favelas não devem-se apenas ao processo migratório nordeste-sudeste, mas aos movimentos migratórios internos provocados pelo empobrecimento da população.

A falta de segurança, problemas no policiamento como quantidade insuficiente, mal preparo e corrupção de policiais é outra idéia dominante. É manifestada em vários discursos em diferentes questões. A estas categorias acrescentamos aqueles que atribuem à impunidade a questão da violência. MESQUITA (1998) discute estas questões, assim como CARDIA,ADORNO E POLETO(2003).

O não reconhecimento do Estado, enquanto capaz de prover a ordem e a justiça e também em ser exemplo aos cidadãos em especial aos mais jovens, é contundente nos discursos apresentados, o que é corroborado por diversos autores e em todas as mídias existentes que fartamente nos descrevem e mostram com imagens a distorção do papel do Estado. 
Outro tema que merece destaque nas representações encontradas é o papel do consumo de álcool e drogas e da disputa de pontos de venda de drogas e luta por poder, por parte dos traficantes. Vários municípios como por exemplo Diadema no estado de São Paulo apresentaram queda em indicadores de violência. Outros países como a Colômbia lograram bons resultados na diminuição de seus índices de violência ao adotarem em conjunto com outras, medidas que visavam a redução do consumo destas substâncias.

GAWRYSZEWSKI, KAHN e MELLO-JORGE (2005), encontraram entre as vitimas de homicídio grande percentual de consumo de álcool que pode ter o papel de potencializador de conflitos.

A questão familiar é a principal representação social quando tratamos da violência contra a criança. Com nuances diversos como despreparo dos pais, falta de estrutura familiar, negligência, surge o papel da família enquanto agressor, mas também como primeira célula da sociedade capaz de dar continência a estas questões. MINAYO(2006) nos fala sobre a violência contra a criança e adolescente dentro da estrutura familiar enquanto válvula de escape das tensões familiares.

O preconceito surge enquanto explicação para a violência na questão que aborda o assassinato de rapazes negros, sendo referido não apenas o preconceito racial mas num sentido mais amplo e inclusive quanto à discriminação das pessoas em decorrência de seu local de moradia.

PAUGAM (1996) identifica na Europa pós-guerra a discriminação por parte de comerciantes e empregadores em relação aos moradores de conjuntos habitacionais que foram construídos para a população desempregada e os inadaptados. Os moradores do Jacira e parque Paraíso, tanto familiares de vitimas de violência como protagonistas da mesma, referem ser o morar na periferia decisivo ao não acesso a bens materiais e simbólicos como o emprego. Referem 
que mencionar o local de moradia - bairros da periferia comumente associados à pobreza e violência - os afasta do acesso ao mercado de trabalho.

O poder paralelo surge não apenas como uma ameaça ao estado de direito; A sua outra face vem à tona sendo apontado também como capaz de restaurar a ordem perdida, com um papel paternalista de "proteção e cuidado" àqueles que estão em sua área de influência.

A quebra das redes sociais e a necessidade de se restabelecerem relações de compadrio e vizinhança e redes de proteção aos jovens são apontadas, junto com a perda da capacidade de sonhar e elaborar projetos de vida como determinantes da violência. A publicação do Ministério da Saúde editada em 2006 intitulada "Violência Faz Mal à Saúde" destaca o importante papel das redes de proteção às vítimas de violência.

Algumas representações contidas nos discursos, apesar de não aparecerem com grande freqüência merecem destaque: Influência da mídia não só na veiculação de programas e mensagens violentas mas também na "glamourização" do crime, a identificação pelos jovens do crime como fonte de status e poder, o medo e a lei do silêncio, a perplexidade dos pais.

Outro aspecto importante de ser apresentado é a atribuição à saúde do papel de bem atender não só as situações de violência. Manifestam não acreditar ter este setor um papel específico para o enfrentamento deste problema que não o já mencionado. Educação e segurança sim, têm na opinião dos entrevistados um papel a cumprir na prevenção e redução da violência. GAWRYSZESKI et al abordam esta dificuldade na definição do papel da saúde na prevenção. SILVA,R, 2006 nos fala sobre a violência institucional.

O fato da predominância da utilização de arma de fogo enquanto instrumento de homicídio contribui para que grande parte das vítimas não tenha 
assistência médica, o que pode estar associado ao não reconhecimento do papel da saúde no reconhecimento do problema.

Entre os que atribuem qualquer outro papel ao setor saúdes, destacam as ações de promoção e educação e a alimentação de sistemas de informação.

É importante registrar o reconhecimento nestes discursos que a saúde reproduz a violência à medida em que impõe regras institucionais que não levam em conta dimensões humanas, reproduzindo preconceitos e relações de poder e submissão.

Estas falas nos remetem à complexidade que nos falam MORIN(1996); LÈFEVRE,F. LĖFEVRE,A.e MARQUES(2007).

MORIN em conferência realizada no Tuca em 1996 nos ensina que conhecer é sempre relacionar uma informação a seu contexto.

LĖFEVRE, LÉFEVRE e MARQUES (2007) referem-se às representações sociais como "fenômenos complexos que extrapolam largamente suas manifestações verbais". Não são o que as pessoas pensam em seu sentido mais restrito, mas possuem capacidade de ampliar seu poder explicativo. 


\section{Considerações Finais}

Ao analisarmos as estratégias ou sugestões encontradas nos discursos obtidos, nos deparamos com multiplicidade de abordagens que abrangem diversas categorias estudadas como questões relacionadas à segurança, policiamento, acesso a trabalho, educação, maior rigor da justiça, recuperação de laços de solidariedade familiares e comunitários, mudanças de políticas econômicas, discussão da forma em que a sociedade está organizada.

Estas propostas de enfrentamento apesar de expressas de formas simples encontram respaldo nos autores estudados e nas experiências exitosas que vêm sendo levadas a efeito.

As desigualdades sociais como causa e sua superação enquanto estratégia no enfrentamento da violência, encontram eco na discussão feita por ZIONI, (2006) ao rever a exclusão social. Os autores mencionados discutem este processo como não individual, e sim social inerente à forma como a sociedade moderna se organiza e cuja superação necessita da intervenção do Estado dada a magnitude que alcança.

A abordagem da violência exige atuação em diversos aspectos da vida social, tanto concretos como simbólicos.

Experiências de países como Colômbia, Estados Unidos, e algumas bem sucedidas experiências no Estado de São Paulo, mostram que há um longo caminho a ser percorrido.

O aprimoramento do aparato policial com propostas como a de unificação das policias como nos traz BICUDO (2000), é uma imposição. Reconhecer a não adequação da estrutura da Segurança Pública no Brasil para fazer frente a um Estado de direito, democrático, é o primeiro passo na superação de seus 
problemas que vão do pequeno efetivo, recursos inadequados, insuficiente incorporação de inteligência, má preparação do policial, corrupção de parte dos seus membros que causa desconfiança na população que por ela deveria se sentir protegida.

Os discursos trouxeram à tona questionamentos em torno do judiciário: faltam leis no Brasil ou falta o cumprimento da lei? A sensação da impunidade aparece como um impulsionador da violência. É sugerido maior rigor na lei e na sua aplicação. Novamente BICUDO (1997) nos auxilia quando discute a necessidade da reforma judiciária para fazer frente à impunidade.

Em situações como a enfrentada pelo município em discussão, com coeficientes de mortalidade por homicídios superiores aos de Bogotá, a tentação em solucionar a violência através da adoção de regimes de exceção é muito grande e claramente manifesta por segmentos sociais que em comum têm dividir o mesmo espaço/bairro e condições de acesso a bens e serviços semelhantes. Identificamos estratégias como punições mais severas, pena de morte, compartilhadas por familiares de vitimas de violência e protagonistas da mesma.

O esgarçamento do tecido social claramente manifestado na desconfiança em relação ao próximo, às instituições, ao Estado, trazem a preocupação com a defesa dos direitos humanos. BICUDO (2003) nos ensina que o homem não pode encontrar a realização dos seus direitos senão no interior de uma sociedade livre de toda contenção externa ou interna. O interesse do indivíduo se confunde com o da sociedade.

A saúde deve desempenhar o seu papel com ênfase em ações de prevenção primária conforme sugerido em diversos dos discursos obtidos que indicam a realização de grupos e palestras como ações de educação em saúde. 
Não pode, entretanto negligenciar o seu papel no desenvolvimento de protocolos de atendimentos às vítimas da violência, alocação de recursos em serviços de urgência/emergência, capacitação dos profissionais e no atendimento pré-hospitalar.

A recuperação da educação no enfrentamento e não como geradora de mais violência é outra estratégia referida em diversos momentos das entrevistas. Aparece como depositário da confiança de ser um caminho para a mudança de vida, apesar dos relatos de hoje, na forma como é vivenciado nestes bairros, ser apenas um retrato, reproduzindo os conflitos existentes naquela sociedade.

O combate ao alcoolismo e consumo de drogas enquanto potencializador de conflitos, hoje realizado através da adoção da "Lei Seca", é outro grande enfrentamento a ser realizado.

Além das propostas concretas, outras de conteúdo simbólico, foram apresentadas como o ir para as ruas e praças, mais união, valorizar a harmonia familiar, maior atenção dos pais aos filhos, recuperar o valor da fé, do divino; cultivar a paz, resgatar o sonho.

Estabelecer políticas públicas de enfrentamento para este problema não repousa em uma única área de conhecimento ou ação específica. Recentemente temos lido artigos de jornais e revistas de grande circulação que abordam a experiência no Jardim Ângela - SP na redução de seus índices de violência como merecedores de esperança. Traz em sua construção o olhar dos diversos atores sociais envolvidos tanto pelo lado de seus moradores como pelo das autoridades, organizações não governamentais, igrejas e outros, que promovem o protagonismo na busca de soluções. 
A utilização do Discurso do Sujeito Coletivo abre novas possibilidades de diálogo entre o todo e as partes, 0 individual e o coletivo, a descrição e a interpretação...(LÈFEVRE, LĖFEVRE e MARQUES, 2007).

Os discursos encontrados são tão eloqüentes que são auto-explicativos. Carecem de análise, mas não de explicação. Falam por si só.

A complexidade do objeto de estudo nos levou a olhá-lo de diversos pontos. Dos que a cometem à dos que sofrem seus efeitos. Esta multiplicidade de olhares traduz também a complexidade do pensamento.

Percebemos que o senso comum encontra eco nas idéias defendidas na academia e nos formuladores de políticas públicas.

O fazer foi nos apontando os caminhos. Sugestões feitas pelos entrevistados foram adotadas e mostraram seu acerto.

Surpreendemo-nos com o compartilhamento de idéias semelhantes pelos componentes dos diversos grupos, o que se impõe à nossa curiosidade como um novo corte a ser estudado.

As estratégias de enfrentamento do problema sugeridas mostram sua factibilidade e principalmente a importância de se deixar falar e de ouvir, mas ouvir com atenção uma fala legítima.

Ao longo deste estudo muitas coisas e fatos novos aconteceram em Itapecerica da Serra: Foi implantada a Lei Seca com determinação de horário de fechamento de bares. 
Esta medida apresentou reflexo no ano seguinte à sua implantação, com redução nos índices de violência desse município tanto em números absolutos quanto relativos

Foi construído pelo governo do Estado um Centro de Detenção Provisória (CDP) que motivou discussões acaloradas, sendo transformada em plataforma política.

A discussão da Cultura de Paz em contraposição à cultura da intolerância foi materializada enquanto proposta da sociedade através da realização de Conferência Municipal da Cultura de Paz, com a participação de todos os setores da municipalidade e da sociedade civil.

Esta conferência teve como desdobramento a edição de lei que criou o Conselho Municipal de Cultura de Paz.

Este conselho, eleito no fim de uma gestão municipal, não teve forças de manter sua atuação na nova gestão.

O assunto não se esgota nessa tese ou em qualquer outro estudo, mas na soma de todos eles e na discussão de toda a sociedade sobre este tema. Qual o mundo que queremos para nós e nossos descendentes.

Nossa pretensão nunca foi a de esgotar o assunto mas sim o de contribuir com o debate. Esperamos ter alcançado nosso intento. 


\section{REFERÊNCIAS BIBLIOGRÁFICAS}

ADORNO, R. Exclusão, insegurança, vulnerabilidade: Incluir com acesso à saúde? Saúde e Sociedade, 2006;15(3):7-10 editorial

ADORNO, S., LIMA, R. S., BORDINI, E. B. T. $O$ adolescente na criminalidade urbana em São Paulo. Brasília: Ministério da Justiça, Sec. de Estado dos Direitos Humanos, 1999.

ADORNO, S, LIMA, R. S., BORDINI, E. B. T. O adolescente e as mudanças na criminalidade urbana São Paulo em Perspectiva,1999;13(4):62-74

AGUDELO, S. F. La violência: um problema de salud publica que se agraba em la región. Boletin Epidemiológico de la OPS, 1990;11:01-07

AKERMAN, M., BOUSQUAT, A. Mapas de risco de violência São Paulo em Perspectiva, 1999;13(4)112-120

BARATA, R. B. Violência Urbana e Saúde Pública. Revista da Saúde,2002;3:22-24. 
BARATA, R. B., RIBEIRO, M. C. S. A., MORAES, J. C. Desigualdades sociais e homicídios em adolescentes e adultos jovens na cidade de São Paulo em 1995. Revista brasileira de epidemiologia, 1999;2(1/2):50-59

BARROS, M. D. A., XIMENES. R, LIMA, M. L. C. Mortalidade por causas externas em crianças e adolescentes: tendências de 1979 a 1995. Revista de saúde pública, 2001;35(2):142-149

BAUDRILLARD, J. A Transparência do Mal. Ensaio sobre os fenômenos Extremos. $3^{\text {a }}$ Ed. Papirus Editora, Campinas-SP,1996.

BEATO FILHO, C. C. Políticas públicas de segurança e a questão policial São Paulo em perspectiva, 1999;13(4):13-27

BICUDO, H. A violência e a estrutura judiciária brasileira Estudos avançados, 1997;11(30):67-78

BICUDO, H. A unificação das polícias no Brasil Estudos avançados, $2000 ; 14(40): 91-106$

BICUDO, H. Defesa dos direitos humanos: sistemas regionais Estudos avançados, 2003;17(47):225-236 
BYDLOWSKI, C. R. Cidadania o papel do professor. Tese apresentada à FSP-USP para obtenção de título de doutor, 2005

CAMARGO, A. B. M. Mortalidade por causas externas no Estado de São Paulo e suas regiões, Tese apresentada à FSP-USP para obtenção título de doutor,2002.

CARDIA, N., ADORNO, S., POLETO, F. Homicídio e violação de direitos humanos em São Paulo Estudos Avançados, 2003; 17(47):42-72

CASTRO, M. S. M., ASSUNÇÃO, R. M., DURANTE, M. O. Comparação de dados sobre homicídios entre dois sistemas de informação, Minas Gerais. Revista de Saúde Pública, 2003;37(2):168-76

COHN, A. Estado e Sociedade e as reconfigurações do direito à saúde. Ciência e Saúde Coletiva, 2003;8(1):9-18

COSTA, M. C. A violência urbana é particularidade da sociedade brasileira? São Paulo em Perspectiva, 1999;13(4):3-12

DALLARI, D. A. Elementos da teoria geral do Estado. Saraiva, São Paulo, 2000

DEMO, P. Participação é conquista Cortez, São Paulo, 2001 
DRUMOND JR.,M Homicídios e desigualdades sociais na cidade de São Paulo: Uma visão epidemiológica. Saúde e sociedade,1999;8(1):63-81

GAWRYSZESKI, V. P. et al Moradores de rua e os homicídios em São Paulo Boletim Epidemiológico Paulista,2004;9:1-6

GAWRYSZESKI, V. P., KOIZUMI, M. S., MELLO-JORGE, M. H. P. As causas externas no Brasil no ano 2000: comparando a mortalidade e a morbidade. Caderno de saúde pública, 2004;20(4):995-1003

GAWRYSZESKI, V. P., KOIZUMI, M. S., MELLO-JORGE, M. H. P Informações sobre homicídios e sua integração com o setor saúde e segurança pública. Ver. Saúde Pública, 2005;39(04):627-633

JACOBI P. R. Políticas sociais locais e os desafios da participação citadina. Ciênc. Saúde Coletiva, 2002;7(3):443-454

JODELET, D. AS Representações Sociais. Ed. UERJ, Rio de Janeiro,2001.

KOVARICK, L. Sobre vulnerabilidade socialcivil : Estados Uniudos, França e Brasil. Rev. Brasileira de Ciências Sociais, 2003 ; 18(51) 
KRUG, E. G. et al, eds. Relatório mundial sobre violência e saúde. Genebra, world Health Organization, 2002.

LEFÈVRE, F., SPÍNOLA, A. D. de P. Pesquisa Qualitativa: Novas Metodologias de Análise Temática de Discursos. São Paulo;1999. [Curso de Verão - Faculdade de Saúde Pública da USP].

LEFÈVRE, F., LEFÈVRE, A. O Discurso do Sujeito Coletivo. Um novo enfoque em pesquisa qualitativa ( Desdobramentos ). EDUCS,Caxias do SulRS, 2003

LÈFEVRE, F., LèFEVRE, A., MARQueS, M. C. C. Discurso do Sujeito coletivo, complexidade e e auto $\quad$ organização http://www.abrasco.org.br/cienciaesaudecoletiva/artigo/artigo_int.php?id_art igo $=622,2007$

LÓPEZ, M. V., MEDINA, M. C. H., PACHECO, R. A. R., MUÑOZ, J. B. Muertes por homicídio, conseqüência fatal de la violência. El caso de México, 1979-1992 Revista de saúde pública,1996; 30(1):46-52

MACEDO, A. C. et al Violência e desigualdade social:mortalidade por homicídios e condições de vida em Salvador, Brasil Revista de saúde pública,2001;35(6):515-522 
MAIA, P. B. Vinte anos de homicídios no Estado de São Paulo São Paulo em Perspectiva, 1999; 13(4)121-129

MARTINS, J. DE S. Exclusão social e a nova desigualdade.Paulus, São Paulo, 1997

MELLO-JORGE, M. H. P., YUNES, J. Violência e saúde no Brasil Revista USP, 2001;51:114-127

MELLO-JORGE, M. H. P. Mortalidade por causas violentas no município de São Paulo, Brasil. I - Mortes violentas no tempo. Rev. de saúde pública, $1980 ; 14: 343-357$

MESQUITA, M. Violência, segurança e justiça: a construção da impunidade RAP, 1998;32(2):109-134

MINAYO, M. C. Violência e Saúde Sustentação,2003;11:3-9

MINAYO, M. C. de S. A Violência Social sob a Perspectiva da Saúde Pública.Cad. Saúde Publ.1994;10(supl 1 ):07-18.

MINAYO, M. C. de S. O Desafio do Conhecimento. Pesquisa Qualitativa em Saúde,4ª Ed., Hucitec-Abrasco, São Paulo/Rio de Janeiro,1996,254p. 
MINAYO, M. C. de S. Violência sob o Olhar da Saúde. A infrapolítica da contemporaneidade brasileira.Ed. Fiocruz, Rio de Janeiro,2003.

MINAYO,M.C.de S.et al. Teoria, Método e Criatividade, Editora Vozes, Petrópolis, 1999.

MORIN, E., Complexidade e ética da solidariedade Conferência realizada no Tuca, 1996

NASCIMENTO, E. P. Globalização e exclusão social: fenômenos de uma nova crise da modernidade. In DOWBOR, L. IAM, O., REZENDE, P. E. (org) Desfios da globalização, Vozes, São Paulo, 1994

NETO, P. M., ALVES, R., coord. Terceiro Relatório Nacional sobre os Direitos Humanos no Brasil 2002-2005. São Paulo: NEV/USP, 2007.

NORONHA, J. Trauma: A Epidemia do Começo de Um Novo Século. Revista da Saúde, 2002;3:42.

OLIVEIRA, L. Os excluídos existem? : Notas sobre a elaboração de um novo conceito. Rev. Brasileira de Ciências Sociais, 1997;12(33):49-61 
ORGANIZAÇÃO MUNDIAL DE SAÚDE Relatório mundial sobre violência e saúde, Genebra;2002

PERES, M. F. T., SANTOS, P. C. Mortalidade por homicídios no Brasil na década de 90: o papel das armas de fogo Revista de saúde pública,2005;39(1):58-66

PERES, M. F. T., CARDIA, N., SANTOS, P. C., coord. Homicídios de crianças e jovens no Brasil: 1980-2002. São Paulo: NEV / USP, 2006.

PORTO, M. S. G. A Violência Urbana e Suas Representações Sociais. O Caso do Distrito Federal. São Paulo em Perspectiva,1999;13(4):130-135

RIBEIRO, L. C. Q., SANTOS JÚNIOR, O. A. S. Democracia e segregação urbana: reflexões sobre a relação entre cidade e cidadania na sociedade brasileira Revista eure, 2003;29(88):79-95

RIBEIRO, M. Educação para a cidadania: questão colocada pelos movimentos sociais. Educ. pesq., 2002;28(2):113-128

ROLNIK, R. Exclusão Territorial e Violência. São Paulo em Perspectiva, 1999;13(4):100-111. 
ROLNIK, R. Exclusão Territorial e Violência: O Caso do Estado de São Paulo, Revista da Saúde, 2002;3:25-26.

SÁ, C. P. Sobre o núcleo Central das Representações Sociais. Ed. Vozes, Petrópolis, 1996.

SALLA, F., Coord. Relatório de cidadania: os jovens e os direitos humanos. São Paulo: NEV/USP, ano- pós 2002?

SANTOS, M. Território e Sociedade. Entrevista com Milton Santos.Ed. Fundação Perseu Abramo. São Paulo-SP,2000.

SAWAIA, B. As Artimanhas da Exclusão. Análise psicossocial e ética da desigualdade social. 2a Ed. Editora Vozes, Petrópolis-RJ,1999.

SAWAIA, B. Morar em favela. A arte de viver como gente em condições negadoras da humanidade São Paulo em Perspectiva, 1990;4(2):46-50

SCURO NETO, P. O Mistério da Caixa Preta. Violência e Criminalidade. Ed. Oliveira Mendes,SP,1998.

SOUZA, R. G. Homicídio no Brasil. O Grande Vilão da Saúde Pública na Década de 80.cad. saúde publ, 1994;10(supl 1 ): 45-60. 
VASCONCELOS FILHO, E. V., SAMPAIO, J. J. C. Homicídio e saúde pública em Fortaleza Sustenteção,2003;11:10-19

YUNES, J., RAJS, D. Tendência de la Mortalidad por Causas Violentas em la Poblacion General, Entre los Adolescentes y Jovenes de la Región de lás Américas. cad. Saúde publ, 1994; 10(1 ): 88-125

ZAICANER, R. LÈFEVRE, F. Mortes por homicídio em Itapecerica da Serra Boletim do Instituto da Saúde, 2004;33:24-26

ZIONI, F. Exclusão social: noção ou conceito? Saúde e sociedade, $2006 ; 15(3): 15-29$ 
ANEXOS 


\subsection{ANEXO 1 - Termo de Consentimento Livre e Esclarecido}

\section{PESQUISA: A Violência Enquanto Problema de Saúde Pública: Percepções e Possibilidades}

Esta pesquisa realizada como condição parcial para a obtenção do grau de Doutor em Saúde Pública pelo Programa de Pós - Graduação da Faculdade de Saúde Pública da USP, objetiva produzir conhecimentos sobre as representações sociais da violência e o papel da saúde pública no seu enfrentamento.

O conhecimento produzido poderá contribuir na elaboração de políticas públicas locais para o enfrentamento do problema da violência.

Pesquisadora Responsável

Eu,

afirmo que, após ter sido informado sobre os objetivos e procedimentos metodológicos da pesquisa acima referida, concordei em conceder entrevista à pesquisadora responsável e/ou entrevistadora cadastradas na referida pesquisa, que expressou seu compromisso em resguardar a minha identidade enquanto entrevistado, zelar pelo sigilo em torno das informações confidenciais recolhidas, bem como providenciar a divulgação dos resultados da pesquisa.

Estando de acordo com os termos da pesquisa e ciente de que não há necessidade de qualquer procedimento de coleta de material biológico ou informação clínica sobre o entrevistado, assino esse Termo de Consentimento Livre e Esclarecido.

Itapecerica da Serra, de de

Entrevistado(a)

Nome:

RG:

Pesquisadora: Raquel Zaicaner

Rua Lícia Borges, 45 Embu - SP

Fone: 11- 98541949 


\title{
8.2 ANEXO II - ENTREVISTAS
}

\author{
Entrevistado: A. G. \\ Familiar de vítima de homicídio
}

1. Um trabalhador, voltando para casa, passa na frente de um bar, onde está tendo uma briga, de repente se ouve um tiro e o moço cai morto no chão, de bala perdida. O que o senhor tem a falar sobre isso?

Eu acho que se a polícia agisse com efetivo maior para revistar as pessoas e não houvesse corrupção da parte policial, não existiria essa arma que disparou e acabou acertando uma pessoa inocente. Porque a maioria das armas, elas são fabricadas, e para se comprar elas, você tem um registro, e no fim, cai na mão do bandido, que nem documento tem. Isso é porque existe corrupção policial, porque senão esse cara não conseguiria nunca comprar uma arma e nem tampouco a munição. Porque um trabalhador, se eu quiser comprar uma arma, eu tenho muita dificuldade para adquirir essa arma. E, no entanto os maus elementos, os bandidos, andam sempre armados. A polícia pega a arma deles aqui e vende para outro lá na esquina, e que depois acaba retornando para a mão dele. Então eu acho que isso, o problema maior é a corrupção policial. Por isso que existe tudo isso aí. Se não houvesse corrupção policial, a arma era presa, o bandido era preso, entendeu? E, no entanto, evitava tanto esses problemas. Eu falo porque eu moro aqui num local que tem muita criminalidade. Não conheço nenhum policial corrupto, também não é interesse meu, porque tem as autoridades para apurar isso. Se eu cometer um deslize, eu imagino que eles vêm em cima de mim, então se o policial comete, tem a autoridade superior a ele para ver isso aí, no entanto, ninguém se interessa, né? E aí acaba acontecendo isso aí. Daí outro dia, moleque com 12 anos, 10 anos, está com arma na mão. Quem deu essa arma? Não foi ele quem fabricou. Essa arma veio da mão de alguém. Não é verdade? Então o que eu penso é isso teria que primeiro corrigir, esse negócio de dizer que menor de idade não pode ir para cadeia, que isso aí é balela, isso aí é safadeza. Por que? Eu comecei a trabalhar com carteira registrada com menos de 13 anos. Eu cheguei aqui em São Paulo, com menos de 13 anos. E, no entanto, nenhum dos meus colegas que começaram da minha época virou bandido, porque todos trabalhavam com carteira registrada. O que acontece? Se eu, ou qualquer um de nós, na época fosse pego fazendo qualquer coisa errada, a gente pagava. Primeiro os pais tinham pulso para corrigir, porque hoje um pai não pode corrigir um filho, se um pai dá um tapa no filho porque o filho errou aí vem tantas coisas, Conselho Tutelar e mais não sei o que, que vem contra o pai, mas não procura saber o que o filho aprontou, entendeu? Então o pai perdeu o poder que tinha sobre o filho. Aí o que acontece? Lá fora autoridade também não corrige. Vai lá para a FEBEM para ensinar ele virar bandido. Porque quando ele vai para lá, ele vai como aprendiz, vai como estagiário e volta formado como bandido profissional. Aí sai na rua com 16 anos matando todo mundo que ele tem direito, que ele imagina que ele tem direito de matar, entendeu? E, no entanto, no dia que ele é preso, ele mesmo fala, na cara da vítima, ele fala "eu sou menor, eu sou de menor, eu sou de menor e não acontece nada comigo", e pronto. E as autoridades são corruptas, inclusive os legisladores, os que fazem as leis, porque eles sabem muito bem, porque se a gente trancar um padre que defende os direitos humanos, com toda sinceridade, dentro de um quarto, e um deputado que defende os menores; 
dentro de um quarto desse daqui, junto com dois bandidinhos de 15 anos, 14 anos, cada um com uma arma na mão, deixar eles pelo menos 3 dias, se eles conseguissem sobreviver, aí tinha que dar parabéns para eles. Se os caras não arrancassem o dedo, com, desculpa a força de expressão, coração deles, para comer na hora da fome, aí tinha poder essas leis. Porque são muito safados, muito corruptos. Todos que defendem bandidos são bandidos, na minha opinião. Porque eu sinto na pele a perda que eu tive de perder um sobrinho, estou falando com sinceridade, me emociona de falar, entendeu? $\mathrm{E}$ isso aí, nenhum vagabundo desses que faz as leis para defender bandido, sentiu isso aí na pele, porque o dia que sentir, eles vão mudar de idéia. Só que infelizmente eles vivem rodeados de guardas, rodeados de câmeras, muros altos, andam de avião, helicóptero, carro blindado. E eu não, eu ando de pé, na rua, eu estou exposto ao perigo, só que eu não tenho poder para mudar nada, infelizmente é assim.

2. Deixa eu contar outra história. Uma moça, uma estudante, estava voltando para casa da escola e foi arrastada para o mato e estuprada. O que o senhor fala disso?

Eu falo que é o seguinte, a vítima vai ter esse trauma para o resto da vida dela, a família dela que paga imposto para sustentar o Governo, se caso esse ladrão, esse estuprador for pego, vai ter que pagar imposto para sustentar vagabundo lá na cadeia. Isso que é triste é saber que além da vítima ter sido estuprada e morta, entendeu? Se algum dia esse ladrão ser pego, você ainda ter que trabalhar dobrado para pagar taxas e impostos para sustentar esse vagabundo que causou tanto mal na sua vida. Então, é por isso que eu digo, ou põe o ladrão, estuprador; estuprador nem se fala, entendeu? Ou pára para fazer alguma coisa na vida para trabalhar, ou enche um navio com eles e solta em alto mar, dá comida para os tubarões, entendeu? Porque não é justo um ser humano viver sempre nessa situação, igual está aqui ou no Rio, e em tantas cidades grandes por aí, entendeu? As pessoas trabalhando, com medo de vir embora para casa, porque sabe que está correndo sério risco de vida. Está pior do que na selva, mas o que acontece? Não tem ninguém com boa vontade e interesse político para mudar a situação. Só vai mudar o dia em que começar a pegar o quanto esses vagabundos, desses políticos que não fazem nada para a população e acontecer com eles o que acontece com a população na rua, entendeu? Porque nós somos povo, nós estamos pagando isso aí, eles não são povo, eles são elite, entendeu? Então eles são diferentes da gente. Eles passam aqui com carro blindado, se acontecer uma bala perdida e pegar o carro deles, não acontece nada. Agora um coitado que anda à pé ou de bicicleta na rua aí, está exposto, entendeu? E na realidade é quem é honesto. Porque esses safados aí são honestos até o dia em que assumem o poder. Depois que assume o poder, todo mundo muda de opinião e isso é o mal. Se tivesse um sistema mais duro aí, uma punição maior para quem fosse pego, esse negócio de bom comportamento, sai com não sei quanto tempo, isso é safadeza. O cara chega lá e vira mocinha lá dentro para ficar bom, quando sai na rua, sai matando d mesmo jeito, a mesma coisa.

3. Me diga uma coisa, num bairro tem uma briga entre dois grupos para disputar o domínio numa região. Pessoas que faz parte de um grupo são mortas pelas pessoas do outro grupo. Fala um pouquinho sobre isso.

Eu acho que isso é o seguinte, tem uma parte bíblica que diz que tudo que não presta morre por si mesmo. Isso é verdade, é bíblico isso aí, entendeu? Se eu que estou aqui na Terra, não acreditar no que está escrito na Bíblia, eu estou vegetando, porque a única coisa que diz a verdade que não muda, pode passar anos e sair anos que não muda, é a Bíblia. Então tudo o que não presta é destruído por si mesmo. Eu acho que isso aí, enquanto eles estão se matando, pelo menos é o seguinte, o policial não precisou; se Deus meteu um tiroteio entre policial e bandido, se o policial mata um bandido, o policial é punido, o bandido não é punido. Então eles se matam lá e deixa aqui. Era bom que a bala de um atirada ao mesmo tempo morresse os dois, entendeu? Infelizmente só morre um lado, esse é que é o pior, só morre um lado. Porque senão gente inocente não morria, morria eles. 
4. Comerciantes cansados de muitos assaltos no comércio deles contrataram seguranças particulares, chamados pé-de-pato. Esses seguranças identificam alguns jovens que se viram tentando assaltando o comércio, e matam esses jovens. Me fale sobre isso.

Eu não sou nem a favor de pé-de-pato porque ele é bandido igual a molecada. Se ele está matando ele é bandido também. Eu acho que quem deveria fazer a lei, são esses políticos, esses legisladores aí, e a lei deveria ser cumprida, mas deveria ter um sistema, um julgamento, alguma coisa assim. Mesmo que fosse para julgar e condenar o cara. Mas que tivesse um processo mais ou mesmo assim. Porque não é justo a molecada sair na rua com uma arma e só porque não gostou da cara do outro, ir matando. Eu acho que essa molecada até deveria morrer, mas morrer pela mão do Estado, porque a população não paga imposto para esse pé-de-pato, não paga nada. Então, o Governo, se ele não tem coragem de assumir uma postura, então ele não se candidata nada, entendeu? Aí, por isso por falta de uma política mais séria que surge esses pé-d-pato da vida aí. Para sair fazendo justiça com as próprias mãos, que também não é certo. Que nem aquele que matou um lá e foi matar um que não tem nada a ver. Ele é matador do mesmo jeito que os outros.

\section{Falta do Estado?}

Eu acho que o Estado deixa muito a desejar, em todos os aspectos, entendeu? Você vê aqui nós temos uma lixeira, um monte de lixo aqui na frente. Cria bicho e rato de qualquer tamanho aqui que quando vem um caminhão para passar, seria dia sim e dia não, que seria o correto, né? Às vezes passa 2 ou 3 semanas sem passar. $E$ cadê os vereadores, cadê todo mundo. Tem que tomar uma atitude. A Prefeitura é uma merda também que só sabe arrecadar. Esses dias aí asfaltaram as ruas ali para baixo e fizeram uma festa para comemorar, cobrando de cada um que tem uma frentezinha de terreno lá, 24 prestações de 200 e poucos por mês. É motivo para eles fazerem festa? Quem está pagando é a população. E eles estão asfaltando com o dinheiro do povo e querem aparecer ainda. Inclusive veio o Prefeito aqui fazer essa festa, é que não era a minha rua, mas se fosse, e eu estivesse aqui, eu iria lá falar isso aí, entendeu? Então eles deixam a desejar em todos os aspectos. Aí, o que acontece? Começa a surgir o quê? Surgir esse pessoal aí, matadores ai que também são bandidos também. Porque a partir do momento que alguém está disposto a tirar a vida de um, seja ele quem for, ele é bandido também. Eu acho que deveria ser tirado pelo Estado. O Estado deveria ter um poder que, dependendo do crime que a pessoa cometesse, matou, morreu. Na minha opinião. Mas ser morto pelo Estado, para ser julgado em cadeia de televisão, para todo mundo ver, e ninguém virava bandido. Porque eu me lembro muito bem, quando eu era criança, eu duvido que se eu chegasse em casa com 1 Real, naquele tempo não era Real, mas com qualquer valor que fosse, e falasse para minha mãe e meu pai, se eu não levava uma surra e tinha que colocar onde eu achei. E apanhava. Noutro dia, eu podia ver 10 Reais no chão que eu não pegava, entendeu? Então o que acontece? Hoje ninguém é punido, filho rouba, chega com esse gravador aqui e fala para a mãe, olha o que eu achei; ô meu filho, acha outro para a gente. Mentira, o moleque roubou. Então, tudo isso, é a corrupção que está generalizada, entendeu? Infelizmente, dentro das casas, o pai e a mãe, ao invés de educar o filho, ensinar princípios bíblicos, o sentido assim da vida, que é a família, o amor de Deus, que é interessante; as pessoas hoje em dia se encostam na porcaria da televisão, só querem ver porcaria de Big Brother e Casa dos Artistas e mais não sei o quê, que é putaria total, desculpa a força da expressão, mas é a realidade, isso aí não leva a nada, não edifica a família de ninguém. Só destrói. Uma menininha de 12, 13 anos, ou às vezes menos, está vendo a prostituição na televisão. Ela vai virar o quê? Ela vai aprender o quê? Na cabeça dela? O pai e a mãe do lado, assistindo. Antigamente, o pessoal se preocupava um pouco em conversar, não tinha tanta televisão espalhada, pelo menos, eu não sou contra televisão, eu sou contra os programas que passam na televisão e ninguém também tem coragem de tomar uma atitude quanto a isso. Porque a televisão poderia ser um meio educativo, entendeu? Divulgar as coisas, interessante. Até poderia passar as coisas que quisesse, mas tipo assim, um canal, sei lá, fechado, tipo esses canais de assinatura.

Você pode mudar de canal também. 
Pode mudar de canal, mas quem muda? Você muda? O seu pai muda? Sua mãe muda? Minha mãe, meu pai. Não são vivos, mas, hoje em dia é o seguinte, o ser humano, o ser humano é o seguinte, ele, a fraqueza dele mesmo é voltada para o que não presta, entendeu? É o pecado em geral. E aí, o que acontece? É a cabeça do cara, vai acontecendo uma lavagem cerebral que daí a pouco ele acha que tudo é normal. Hoje em dia nudismo é normal na cabeça de muita gente. Isso é normal? Isso não é normal. Teria que ter o que? Aquele primeiro que inventou, vamos fazer uma praia de nudismo? Chegasse um chicote nas costas dele, o outro falaria, eu? Eu estava até pensando nisso, mas não vou mais. É a mesma coisa, essa Globo, para mim é a mais corrupta na minha opinião, na hora que ela colocasse uma cena indecente num horário até 9 ou 10 horas da noite aí, metesse uma multa alta em cima dela, o SBT não colocaria e outro também não colocaria. Agora, o que acontece? Ganha Ibope, ganha Ibope, então a família está sendo destruída, está o final de tudo aqui. As meninas estão virando prostitutas, os moleques é isso aí, um matando o outro no meio da rua. Matando inocente, que não tem nada a ver. Tudo isso por causa de que? Por causa de cabeça fraca, falta de princípio das próprias pessoas, falta de política séria para conduzir tudo. Muita gente fala que a ditadura não é boa, eu sei que não era boa, mas pelo menos tinha ordem e as coisas só é boa quando tem ordem. Não adianta a pessoa pensar que baderna, bagunça ai é boa, que não é. Baderna não é bom para ninguém. Entoa as coisas tem que ter ordem, antigamente eu lembro que se eu ia numa padaria, minha mãe falar, Antonio vai comprar um café, eu ia lá e comprava o café, é X é tal. Se o outro colocasse 1 centavo a mais, eu poderia até ser preso, entendeu? Então, açúcar também era tabelado. Tinham certas coisas, produtos que eram tabelados, então era ótimo. Hoje não tem ordem, hoje você compra um remédio que custa 100 Reais, o outro ali vende por 10 . Conforme a sua cara, conforme o cheque que você está. É assim, virou bagunça, então tinha que ter ordem. Não é voltar à ditadura militar não, é simplesmente ter ordem. Porque a partir do momento que não tem ordem, o governo não tem pulso, porque pensam que o governo é quem manda, mas isso aí, quem manda, as safadezas mais aí são dos deputados e vereadores, são eles que fazem as leis, entendeu? Então aí é aquele negócio, hoje em dia, se você for ver, a grande maioria da população (incompreensível), aí a gente fica preocupado, e é verdade, entendeu? Eu duvido se você sair aqui, se você encontrar aqui, pelo menos $60 \%$ das famílias aqui que não tem um bandido na família. (incompreensível - falando muito rápido). $O$ filho se não quiser ser bandido, que seja correto. A minha opinião é essa, entendeu? Então eu acho que teria que ter mais ordem, linha dura. Tem que ser mais duro igual um monte de paises por aí. Igual na China, eu já ouvi dizer, eu não conheço nada de fora do Brasil, mas já ouvi dizer que se o cara comete um crime bárbaro, ele deve morrer em praça pública e a familia tem que pagar a bala que ele foi executado. Eu acho que isso seria o correto.

5. Deixa eu te contar uma outra história. Uma criança é trazida para o pronto-socorro com o braço quebrado e uma estória que caiu da escada. Um mês depois ela volta de nova cheia de mancha roxa, com uma estória de que caiu da cama.

Eu acho que ai tem que chamar esse pai, essa mãe, ou irmãos mais velhos, se tiver, ir lá na delegacia, conversar um com um e até descobrir quem é que anda derrubando o menino da cama ou quebrando o braço dele, entendeu? Porque não é normal isso daí. Agora, só o que acontece? $E$ justamente isso que eu falo, cadê o poder de investigação, para poder descobrir quem foi? Se foi o pai, se foi a mãe. E se foi o pai e a mãe não denunciou, pegar o chicote nela também, porque tem que pagar quem fez e quem é cúmplice. Porque está cheio de cara, ah fulano fez e tem que pagar, mas e o outro que foi cúmplice. Porque eu sou pai, de dois filhos, se Deus o livre a minha esposa pegar e machucar um deles e eu não tiver capacidade de tentar mudar essa situação, tenho que levar chicotada também, entendeu? Porque é o que eu estou falando, os pais perderam o poder sobre os filhos por causa desses sem vergonhas assim que machuca a criança, porque educar não é deixar mancha roxa, não é quebrar braço. Educar é igual eu fui educado, eu apanhei do meu pai, eu apanhei da minha mãe, hoje os dois são falecidos. Graças a Deus nós somos em 9 irmãos, não tem nenhuma prostituta e nenhum bandido, entendeu? Então, e não é, só que nenhum de nós chegou com o braço quebrado, nenhum de nós chegou, entendeu? Era aquele negócio, respeito, respeito se adquire, chega um momento que de você só falar, a pessoa já 
obedece, não precisa ficar batendo toda hora, entendeu? Esse daí precisa apanhar, esse pai e essa mãe têm que ficar na cadeia lá junto com os malandros para ele aprenderem o que é bom.

\section{Qual o papel do setor saúde na questão da violência?}

Eu imagino que isso aí é mais um descaso das autoridades, por que? Porque eles nunca atrasam o pagamento do IPTU de ninguém, eu mesmo pago o meu IPTU e pago em dia. Se eu quiser ter uma mixariazinha de desconto eu tenho que pagar adiantado. IPVA também é a mesma coisa. Então, a cobrança deles, eles nunca atrasam. Aí eles colocam um médico no Posto, pagam muito pouco para o médico, entendeu? Não dá incentivo para a pessoa que está se formando em medicina, ter esse prazer, falar não, eu vou ser funcionário público, eu vou trabalhar para o Estado, para o Município, sei lá, entendeu? Aí o que acontece? Quando o salário é tão pouco, ninguém quer exercer a função de médico. Vai trabalhar numa vila, só que também está expondo a vida dele ao perigo. Aqui mesmo tem casos de pessoas que vão ser socorridas no Posto e na frente do médico ele é baleado e assassinado e o médico tem que ficar calado, olhando o cara matar ele. Aqui aconteceu isso, entendeu? Então o médico, não tem razão nenhuma para ele trabalhar nesse Posto. Ai já vai trabalhar com má vontade porque está ganhando pouco, estudou tanto para ganhar pouco, entendeu? $E$ as autoridades não têm capacidade sequer de melhorar um pouquinho o salário e dar incentivo, até mesmo faculdade gratuita para as pessoas que não tem condição e tem boa vontade, se formar para a área de medicina e para terminar esses problemas. Porque se tivesse mais gente formada também, já não teria esse problema. Eu acho que a mãe, ela volta revoltada e com razão, entendeu? E aquele negócio, se houver alguma coisa para fazer, tem que fazer contra as autoridades. Tentar processar o Governo do Estado, ou o Prefeito que dirige esse tal Posto, porque o funcionário que está ali, ele não tem como fazer milagre. Se ele tem que atender em 5 minutos e ele atender em 2 minutos, a pessoa não é bem atendida, então não adianta nada, ele tem que preparar o tempo necessário, e o dia tem 24 horas, não tem como aumentar as horas do dia. No outro dia já tem outros com horários marcados. Infelizmente, a população aumentou, a arrecadação do Município e do Estado aumenta todo ano, eles inventam Taxa do Lixo, Taxa de lluminação Pública, taxa de tudo quanto é coisa, entendeu? Mas isso não é revertido em melhoria para a população. E a população acaba pagando de uma forma ou de outra.

\section{Você tem mais alguma coisa que você acha importante falar da violência?}

Olha, eu não sei se é importante o que eu tenho para falar, mas é o que eu penso e o que eu sinto. Cada vez que eu comento da morte do meu sobrinho, meu coração amarra. Amarra de um jeito que por isso que eu estou indo embora daqui. Antes eu não pensava em ir embora daqui, mas eu estou indo embora. Estou indo embora. E tudo o que eu consegui na minha vida com muito trabalho, eu cheguei a trabalhar em 2 serviços, era a minha esposa, eu chegava do serviço tipo meia-noite e ela estava fazendo crochê, nem televisão a gente tinha na época, ela ficava fazendo crochê, para as 2 horas da manhã eu me enfiar na cama e voltar para o trabalho. Isso aí não foi uma e nem duas vezes não, para hoje eu ter que jogar tudo fora por causa de um vagabundo. Não que ele não fez nada comigo, mas do jeito que aconteceu com ele, pode acontecer comigo, pode acontecer com um filho meu, entendeu? Então o que acontece? Estou procurando um lugar mais tranqüilo para sobreviver. Não um lugar bem melhor, mas pelo menos eu imagino para ter mais liberdade assim. E é aquele negócio, esse negócio aí de bandido viver matando aí, eu acho que deveria primeiro mudar a lei. Essa lei que não pune o menor, essa lei que não tem cabimento uma coisa dessas. A partir do momento que a pessoa tem força e mente para planejar como é que vai tirar a vida de alguém, ele tem que ser punido e pagar da mesma maneira, o mesmo que ele fez com aquela vítima, tem que ser feito com ele entendeu? E outra coisa, esses delegados, esses políticos aí, polícia e tantos outros que não tomam uma atitude à altura, têm que ser punidos também. Se fosse comigo um delegado que pegou dinheiro de alguém, se fosse comigo, um policial que deu as costas quando um ladrão pegou alguma coisa só porque pegou algum dinheiro do ladrão, se fosse comigo também, mudava isso daí. Mas, infelizmente ninguém é punido, só é punida a população na rua. Porque nós estamos nas mãos de vagabundos, você não pode nem denunciar, não pode falar mal de ninguém, porque a polícia fala quem pagou. 


\section{Entrevistado: Dona G Familiar vítima de violência}

Dona G. eu vou contar as historinhas, e a senhora vai me falar se é violência, que não é violência, por quê, e falar o que a senhora quiser sobre o assunto. Está certo?

1. Um trabalhador está voltando para casa, aí ele passa na frente de um bar, onde está tendo uma briga e ele morre de bala perdida. Fala sobre isso para mim.

Isso é uma coisa muito triste, doutora Raquel. Que ele vem do trabalho, mas será que alguém foi ali naquele bar conversar com aquele homem do bar, conversar com aquelas pessoas? Só quando a gente passa na pele que a gente mexe com eles, a gente sabe. Antigamente, se tinham as bebidas também, não tinha droga. Era muito pouco. Mas é uma violência, é uma perda total. Isso é a maior violência que se pode ter. Mas eu acho que nós estamos sendo covardes. Nós estamos botando as grades nas portas, fechando as nossas casas, enquanto nós teria que ir para a praça, para as rua, chegar e falar assim, olha Fulano, quando o cara tiver muito para lá de Bagdá, você não vende mais, acalma ele, tenta tirar ele daí. Porque não é possível que o dono do bar também esteja ali, então cabe à justiça, porque um bêbado não pode vender pinga para outro. A senhora entende? Então eu acho que nós temos que ir para a rua. Nós temos que ir para a rua, nós temos que conversar. Eu tinha muito medo de enfrentar, mas eu passei na pele. Talvez a morte do meu filho foi para me dar uma lição de moral. Eu trancava tudo. Eu continuo, eu tranco o portão, mas agora eu não tenho medo de chegar aqui na rua, o cara está empinando moto, tem essa lombada, que eu venho lutando há mais de ano para tirar ela. O cara está aqui empinando moto, está para lá de Bagdá, e eu chego para ele e falo assim, olha, tem pessoas dormindo, tem crianças dormindo e você é um filho muito amado de Deus, não empina a moto aí não. Ah, eu estou atrapalhando? É, o barulho, né? Não é você, é o barulho da moto. Pego o bêbado, pego o doido, doutora Raquel, talvez a senhora me vê afastada, mas tem muitas pessoas no fundo da miséria. E eles ligam para mim e falam vem me ajudar e eu vou. O guarda municipal, o Jorge, não me dá nem quase tempo de nada, é num bairro, é noutro. Não vou dizer para a senhora que eu não chego lá na Câmara e dou até umas brigas com algum vereador. Dou. Porque às vezes você precisa tirar uma foto da pessoa e ainda quer falar para o mês que vem se eu precisava daquilo para onde? Eu não posso tirar do meu dinheiro, o meu dinheiro é muito pouco. A senhora entende? Então eu acho que isso é...

2. Deixa eu te contar outra estória. Uma estudante está voltando para casa depois da escola, daí ela é abordada por um indivíduo que arrasta ela e estupra ela.

Essa é uma violência pior das todas, né? Porque da mesma maneira que foi com a outra, só que aquela lá não veio do estudo, indefesa, é jovem, não tem como ela se defender. $E$ a violência mais dura, doutora Raquel, é que quem viu não ajuda aquela jovem. Porque ele lá pegar o, ele viu a jovem lá no meio do mato sendo estuprada e tudo, às vezes ele ate conhece o cara, mas quando a polícia chega, porque tem polícia boa, tem muita polícia boa, quando a polícia não vi, não sei quem é, e o cara, às vezes, mora do lado. Às vezes o cara está escondido dentro da casa. Quando nós não for covarde, que nós não acordar, porque a polícia não tem bola de cristal. Quando nós não for covarde para nós contar, olha Fulano é isso, e a polícia também tem que fazer a parte dela, não mostrar a cara de quem contou. Porque se a polícia mostrar, ela é mais violenta de quem foi ajudar. A polícia tem que preservar a pessoa que contou. A pessoa ajudou a polícia, deu uma retaguarda, então, olha, foi você mesmo, já tem prova. Mas se a polícia falar, não, foi daquela casa, pode considerar que aquela família ou tem que sumir ou morre. Então aí a polícia é mais violenta ou mais covarde.

3. Deixa eu the contar outra estória. Num bairro tem uma briga entre dois grupos rivais, para disputar o domínio, certo? Pessoas de um grupo são mortas por pessoas de outro grupo. Fala sobre isso. 
Olha, essas pessoas que são rivais, se for da droga, por que elas têm essa força? Elas têm essa força porque elas têm uma capa que protege elas. Aquele homem ou aquela mulher, a maioria são homens, que nós pagamos impostos, que eles entram, porque o polícia, o médico, todos eles, quando entra para trabalhar, o poder público, ele sabe que o salário não é muito alto; mas não pensa que os convênio é muito alto porque não é também. Mas ele já sabe quanto que ele vai ganhar. Então, ele só é disposto, doutora Raquel, ele só faz aquelas brigas, aquelas violências porque eles têm proteção de alguém. Se eles não tiver essa proteção e se eles não pagassem uma propina, eles não fazia. Porque se a polícia chega ali e leva os dois grupo, prende e não deixar o dinheiro entrar no meio, eles não volta para a rua para brigar. E ali no meio é inocente que morre, é mãe que sofre, é pai que sofre, é avó que sofre, filho que sofre, esposa que sofre, e vice-e-versa. Hoje não está mais só o homem na... a mulher está avançando mais que o homem até. Eu acho que se não tiver quem protege eles, se fizer a justiça certinha, eles não vai ter como proteger. Por que como é que eles pode se proteger se eu estou brigando, por exemplo, eu estou brigando com a senhora, mas eu tenho alguém, capa dura, que me protege, então eu estou toda. Eu tenho alguém da própria polícia que me vende a arma. Isso, doutora Raquel.

Fale mais sobre isso para mim.

Isso é uma coisa que eu, achei com as minhas pernas, a senhora entendeu? É muito difícil a senhora saber que a senhora paga, quando a senhora paga o seu imposto, quando a senhora sai do supermercado, isso eu aprendi, com a senhora, com a doutora Vera. Quando a senhora sai do supermercado, a senhora já deixou o seu imposto lá. A senhora andou na avenida, a senhora deixou o seu imposto, a senhora pagou combustível. Todos os lugares a senhora pagou o seu imposto. E esse dinheiro é pago para isso. Agora, para mim dar uma vida boa para a minha família, eu tenho que dar com o meu suor, não com o dinheiro que não é suado, dinheiro ganhado fácil. Aí se eu ganho dinheiro fácil, eu posso comprar carro, eu posso dar carro para amante, eu posso dar carro para o amante, eu ganhei fácil. Eu chego lá e eu faço o acerto. Isso é a coisa que está mais triste. A violência está mais alta, doutora Raquel, e não é, não é o Lula, não é o Fernando Henrique, não é o governador, não é o prefeito. É um povo que prestou concurso e se venderam. Porque o Judas vendeu por 30 moedas. Então se vende, ele vai lá. Isso eu vejo no meu bairro, no meu bairro. Eu fico triste porque eu amo Itapecerica como eu amo a minha cidade que eu nasci, eu tenho amor por essa cidade. A senhora sabe que eu tinha tudo para eu ir embora daqui, tudo, sumir, voltar para a minha terra. Não, eu amo a minha cidade, não tenho medo, fui proibida, quando eu tava andando na rua de noite, não ir para a igreja; eu digo não, não vou deixar de ir para a igreja, não vou deixar de ir para qualquer lugar. Olha, se afasta, não vai; não vou, vou na Guatemala, vou em todo lugar. Saio com a minha santinha vou de noite rezar com as minhas amigas, com as minhas velhinhas, com os meus velhinhos. Vou ajudar buscar ambulância, posso dizer para a senhora uma coisa, quanta gente fala assim, eu ligo para uma ambulância e leva meia hora? Eu não sei qual é a diferença que tem a minha voz, não é nem 5 minutos, a ambulância está onde que eu estou precisando, para socorrer quem está mal, para socorrer outro. Então eu vejo o quanto a pessoa é boa, mas tem que saber olhar e dizer, obrigado Fulano, que você chegou a tempo, que você veio a tempo.

4. Deixa eu te contar outra estória. Uma criança é trazida para o posto de saúde com o braço quebrado e uma estória de queda de escada. Depois de um mês ela volta com umas manchas roxas no corpo.

Aí precisa chamar pai, mãe, quem cuida daquela criança? Se é na escola, se é na casa. E mostrar para a mãe como é a regra para ser mãe. Ver se essa mãe é perturbada, ver se essa mãe não é uma mulher que tem vida irregular, ver se essa mãe não é uma mulher que está querendo ficar livre daquela criança, está querendo mandar mais para uma muntuária de criança, ou Conselho Tutelar, ou Casa Transitória. Às vezes, ela quer ficar livre e fica espancando. Por que? Porque muitas mães, muitas mulheres, doutora Raquel, não está preparada para ser mãe. E não é porque é nova não, mulher já velha, não está preparada. E uma coisa que deveria ser no nosso país, mas isso eu não sei se a gente vai alcançar um dia, essas mulheres que têm um filho, dois 
filhos, solteira, um já é de um pai, o outro já é de outro, quando ela caísse dentro dos hospitais, pronto, o terceiro você não vai ter. Deveria ter uma pesquisa, um Censo, pesquisando. Porque colocar o filho no mundo é a mesma coisa que a senhora construir um posto de saúde $\theta$ não ter médico para pôr nele. A senhora põe um filho no mundo, mas a senhora não pode criar. A senhora concorda? A senhora construiu o posto, mas não tem dinheiro para pôr médico, pôr enfermeiro, ficou só o prédio, é um posto de saúde. É a mesma coisa, é um vaso sem água, é um vaso sem água. Porque eu e a senhora viemos de lugares que nós conhece viúva que criou o filho no cabo da enxada. E foi honesta, direita, maridos morreu, até morreu às vezes matado, brigas, nós sabemos, nas nossas terras teve isso. Divisa, briga por causa de herança temos ou não temos? Mas elas foram honestas, elas foram fiel, batalhou na enxada, lamparina, fogão de lenha, buscou água longe na cabeça e criou os filhos, mas elas tinham aqui, doutora Raquel, o amor. E quando a mulher tem um filho que ela engravidou sem ela preparar, ela vai arrumar, ela não tem amor nesse filho. É mais um que ela vai pôr, como quando a gente for no banheiro e for fazer uma outra necessidade. Então essa mulher tem que ser chamada e esse pai tem que ser chamado.

5. Comerciantes estão cansados de uma onde de assalto no bairro e resolveram contratar segurança próprio, chamado pé-de-pato, né? E, aí identificam quem era que estava assaltando o comércio e aí os pés-de-pato foram lá e mataram os moços. Fala sobre isso.

Olha, doutora Raquel, os comerciantes ficaram cansados de ser assaltados, mas eles cometeram um erro porque eles contrataram pé-de-pato. Eles têm que ir atrás da polícia, exigir do delegado segurança. Porque o pé-de-pato, ele mata e depois um dia ele volta para ser assaltante, volta para assaltar o próprio comerciante. Um dia que ele não tiver mais quem paga para ele, ele vira para o lado do bandido. Se ele mata por isso, ele vira para o lado do bandido.

\section{Qual o papel do setor saúde na questão da violência?}

É uma violência. Sabe por que é uma violência? Porque um paciente a mais ou um a menos não vai atrapalhar o médico. Então o médico está fazendo dois atos maravilhoso, está atendendo um a mais, está ganhando nas escadas da vida que ele vai atravessar. Ele atendeu. Agora, se for um dia que não tem médico mesmo, aquele posto de saúde deve procurar o que? Encaminhar olha leva até o pronto-socorro e dá um telefonema, eu estou mandando uma criança assim e assim, com o número tal tal, atende essa criança que ela está com bastante febre. Eu acho que é o dever de quem está ali no posto, indiferente se é a diretora, se é a auxiliar de enfermagem, qualquer um daqui, ou da recepção, liga no pronto-socorro mais próximo e digo, eu estou encaminhando uma criança para aí, e se a mãe disser, não tenho nem o transporte para ir, procura entre eles, você dá 10 centavos, o outro dá 10 e vai, e manda para o pronto-socorro. Esse eu acho que é o caminho certo a tomar, agora, negar é uma violência. Porque a mãe está desnorteada, não sabe o que fazer. É a mesma coisa se eu encontrar uma criança doente, e eu, final de semana, o posto de saúde está fechado e aí eu vou dizer para a mãe, vamos dar um banho para abaixar a febre, vamos dar umas gotinhas de Depirona, ou qual o remédio que você costuma dar? Vamos dar umas gotinhas, se não abaixou a febre, ensinar a mãe a pôr pouco agasalho, porque a maioria, eu também fazia isso, não vou falar que eu aprendi, mas eu também fazia, eu agasalhava, botava muita roupa. Então, vamos desagasalhar, deixar fresquinha. Se passou, ou se a febre continua, passou um pouquinho e voltou pior, aí a minha obrigação é vamos até o pronto-socorro, vamos até o hospital mais próximo, esse é o dever de cada cidadão.

7. Dona Geralda, a senhora quer falar, tem mais alguma coisa que a senhora acha que é importante falar sobre a violência assim, do que a senhora acha que está na causa da violência, falar sobre a violência, de sugestão que a senhora tem do que fazer em relação à violência?

Olha, doutora Raquel, a senhora era muito jovem nessa época, mas a senhora lembra quando o governo, a polícia parava o trabalhador e queria ver a carteira registrada. $O$ desemprego foi a causa de todo mais a força da violência. A mídia ajudou muito, porque a mídia ajudou numa parte, doutora Raquel. É, nós vimos que hoje em dia, quantas famílias não puderam comprar um ovinho de páscoa, nem um bombonzinho, porque não tem praticamente o arroz para comer. $E$ 
esses jovens, não sentem vontade? Adolescente criança. $O$ pai bate, bate, bate num canto e não encontra trabalho. Quer violência maior a de um homem ficar mendigando, doutora Raquel, pedindo, catando, até as latinhas, os jornal, está uma violência, doutora Raquel, estão se brigando para catar papelão. Entre eles, e não é questão alcoólica não, porque um não quer que o outro pegue da loja do outro, da porta do outro, da papelaria do outro. Então, entre eles, porque eles estão necessitando daquilo, isso é a violência maior que nós temos, então eu acho que nós precisa não é da Fome Zero, desemprego zero. E seja que não dê nenhum centavo de aumento para o salário mínimo, se não der para dar, não dê não, deixe com os 240 , que não vai subir também, mas que ele dê trabalho, que ele pegue esse juro, doutora Raquel, pode ser, podia ser outro e outro qualquer, de outro partido. Abaixa esse juro para os empresários poderem trabalhar, porque, doutora Raquel, quando eu derrubo o meu patrão, eu derrubei eu muito primeiro. Porque ninguém não agüenta mais pagar juro. Então, o que nós precisa é de produção. O nosso país caiu 5 pontos, tem país muito mais pobre que o nosso e está mais fácil. A senhora olha a situação, uma cidade bonita como é o Rio de Janeiro, quem é que vai lá? A moça veio de Minas, morreu, deixou os filhos sem mãe. Então eu pergunto à senhora, o que precisa é trabalho para todo mundo. Aí vai saber, porque você não está trabalhando? Já decretou, antigamente, com 14 anos já podia arrumar emprego, já decretou de 16 anos. Então eu acho que nós precisa de emprego, precisa haver palestra, e isso precisa, haver palestra, chamar o povo, idoso, meia-idade, jovem, adolescente. Chamar para as palestras. As igrejas têm que se ajudar em tudo isso, indiferente de todas, todas elas, todas, têm que se ajudar. Chamar as famílias e resgatar uma coisa que está degradada, família. Familia está degradada. Ninguém mais senta na mesa, conta uma estória na hora do almoço, não conta uma coisa, não conta uma piada, não conta uma coisa assim. Tem tanta coisa que a pessoa não está ouvindo por aí e se lembrar. Porque se eu ganho 240 , o outro ganha que seja até menos do que o salário, mas ele sabe que todo mês ele vai ter aquele dinheirinho. Então, doutora Regina, a família, se nós quiser acabar com a violência, diminuir muita, acabar, acabar nós não vai acabar, porque desde que o mundo foi feito que teve a violência. Se nós quiser acabar nós tem que resgatar a família, valorizar muito a família. Se a gente tiver um filho, uma filha que estiver no caminho errado, a gente começar a olhar onde que a gente também falha. A gente também falha com os filhos, as vezes a gente quer trazer no cabresto muito apertado e o cabresto acaba e estoura. Então a gente tem que haver um diálogo entre o pai e o filho, a mãe e o filho e ajuntar a família e estar sabendo que o casamento, está meio caindo aos pedaços, não porque está acontecendo isso e aquilo outro, ou a gente vê que o cara está pulando a cerca, não vai correndo falar para a mulher, chama o cara e fala, vamos tomar um guaraná em tal lugar, vamos beber uma água? Eu preciso conversar com você. Mas num lugar que não tenha muito conhecido vendo. Ou debaixo de u ma árvore, ou num lugar, porque eu já fiz isso com alguém. Fulano, essa aqui é uma esposa boa, vê onde que está falhando. Abre o jogo limpo com a pessoa, para não deixar aquele casamento acabar. Porque aquele casamento acaba, a mulher vai encontrar outro homem e o marido vai encontrar outra esposa, e os filhos encontram ou pai? Tem criança que a senhora pergunta, um ano na escola, eu falo isso. Pra nós acaba a violência, faz falta o aumento de polícia? Faz, a polícia esta desfraldada, mas nos precisa as famílias ocupar os lugares que os traficantes esta ocupando, nos ir conversar com este jovem, quando nos ensinamos uma criança a criança aprende, e a criança é a melhor multiplicadora da paz, não adianta fechar, Doutora, grades, botar grade de todo lado, eles pegam no portão, então se nos vamos lá e conversamos com eles, se nós resgatamos nossa familia, agora se a gente não resgata nem a familia da gente como e que a gente vai resgatar fora de casa, se a gente entra dentro de casa e briga a familia, briga a mulher, briga os filhos é uma contenda de briga, cada um quer só pra si não sabe dividir o pouco que ganha. Numa família quando tem um desempregado cada um ajuda um pouquinho aquele ate que ele se coloca, vê se consegue colocar ele num trabalho, não, ele não trabalha porque não quer, ai ele sai pra rua ele acha um amigo que paga um copo de bebida, hoje ele bebe amanhã ele já pegou um trago, ai depois de amanhã o outro já convida: vamos fazer um manero ai? Ele vai, ele faz o primeiro não acontece nada, depois ele faz o terceiro e o quarto e ai depois ele esta um profissional, mas ele perdeu lá dentro, a raiz dele foi arrancada lá dentro da família, não foi lá na rua que perdeu ele. Quando a filha pergunta: mãe assim, assim, assim, a mãe às vezes não tem tempo de responder, mas procura uma hora correndo pra dar uma reposta, às vezes esta correndo para o trabalho: não filha, mas eu te prometo que nós vamos conversar isso, marca ai no caderninho nós vamos conversar essa história, é que eu não posso picar o cartão 
atrasado no trabalho, ai ela volta e explica pra filha, conta pra filha como é que ela começou a mocidade dela, como é que ela foi começando o caminhar de adolescente pra mocinha, vai contando, conta para o filho, se o pai é aquele pai careta a mãe faz aquele serviço que era para o pai, senão chega e conversa com o pai e diz: pai você precisa conversar esse assunto com seu filho, mas não chegar e dizer que você é um pai que não. Faz ai não vai resolver, então as pessoas têm que ser amigo, ser familia, achar que nós todos somos família, eu vou dizer uma coisa: eu trabalhei 29 anos com judeu, eles respeitava o sábado, mas a nossa que era o domingo era o respeito dele, quando era a páscoa deles ninguém trabalhava, mas a nossa também não trabalhava, mas era um amor um carinho, a primeira coisa que eles ensinava pra nós, o que nós devia pra ele, estava lá no caderninho marcado, era descontado quando fazia o acerto de contas, o que eles devia pra nós. eles pagava e da ceia da páscoa deles nós tudo comia, era separada a bandeja e todos comiam e eles diziam: vocês tem que ser fiel uns com os outros. Quando eles viam um colega discutindo um com outro eles diziam: não você não tem que brigar com ele achando que ele tomou o freguês seu mostra que você vai vender mais do que ele, quando você sair para o trabalho você pede a proteção dele, então eles davam aula de amor pra nós. Nós tínhamos todo mês uma reunião, uma confraternização no final do ano, no aniversário de cada um tinha uma confraternização, e muitas famílias não fazem mais isso, não se reúne, não faz vamos supor vamos ajuntar nossa rua, um é mais rico, outro é mais pobre, outro é mais ou menos, então tem aquele que é bem de vida, mas não quer misturar no meio dos outros, ai ele vai ver e vai querer se ajuntar. Ou no dia de uma precisão ele vai se ajuntando, ai vai se ajuntando, ai a violência vai diminuir muito e muito, porque não existe mais aquele um que quer saber 0 que aconteceu, não existe mais aquele que quer saber porque o outro chegou tarde, não saber onde o outro estava, falar: ah fulano eu vi sua casa fechadinha aconteceu alguma coisa? Não eu viajei, ou eu vou viajar, mas você dá uma olhadinha pra mim, isso eu acho que é ser irmão porque nós somos todos irmãos. Não é achar que porque eu nasci em Itapecerica, eu sou Itapecericano o outro não é, todos é, somos imigrantes, somos todos irmãos, essa coisa que esta faltando. Outra coisa que está faltando muito nas famílias, é ensinar desde pequeno é ensinar a pessoa qual que é a crença que ele teve, ensinar a criança o caminho de Deus, ensinar que existe Deus, então a criança já vai crescendo naquele caminho naquele andar, Deus tem o tempo dele, mas vai diminuir muito doutora Raquel.

\title{
Muito Obrigado.
}

\author{
Entrevistado: M N \\ Familiar vitima de violência
}

E vou te contar umas histórias, e você vai me dizer o que você acha delas, se você acha que é violência, que não é violência, e por quê. Está bom?

1. Um trabalhador, voltando para casa, passa na frente de um bar, onde está tendo uma briga, está passando na frente, ouve-se um tiro e ele morre de bala perdida. Fala sobre isso para mim.

Como é que eu vou falar sobre isso, meu Deus? Ah, para mim isso é violência, né? O pessoal ultimamente está usando a arma por qualquer motivo. Por qualquer motivo eles tiram a vida. Antigamente não, antigamente o pessoal brigava, com soco, hoje em dia é o revólver. Eu acho isso super errado, eu não aceito. Não tem muito que dizer sobre isso. Sentir na pele é meio...é difícil, né?

2. Num bairro tem uma briga entre dois grupos para disputar o domínio do pedaço. Gente de um grupo é morta por gente do outro grupo. 
Ah, eu não sei, viu? Aí é difícil. É violência por causa da droga, né? Estão disputando o que? Droga. Só pode ser. Porque hoje em dia o que mais se mata é o que? É por causa das drogas, né? A violência é bastante, eles tiram a vida por nada. Aqui mesmo nesse lugar onde a gente mora, vira e mexe, eu vejo isso. Aqui é assim. Aqui ninguém se mete, ninguém fala nada, porque o pessoal tem medo, né? Porque hoje em dia é o tal do silêncio. Sempre fala, nós tem medo. Então fica por isso mesmo.

3. Uma estudante está voltando para casa da escola, daí um indivíduo arrasta ela para o mato e estupra ela.

Uma pergunta que é tão difícil responder. É duro você ter sua filha, você vai para a escola e quando volta o cara faz isso. Ih, meu Deus, se fosse minha filha eu não sei o que faria não, eu não usaria o mesmo método, mas é triste, viu? Eu acho. A pessoa hoje sabe, sabe que sai, mas não sabe se volta mais, né? Não sabe se morre, não sabe se é estuprada, se vai ser assaltada. É muito triste. $O$ mundo está perdido, pensando bem. Imagina o que pensa o pai e a mãe dessa menina. A pessoa fala mesmo quem sente na pele, né? Já teve isso na família. É quem sente mesmo, né? Quem já teve estupro. Eu, graças a Deus, até hoje...Porque é duro. Pensando bem, é duro. Sua filha vai para a escola, você espera ela chegar e não, vem um cara que sem mais nem menos pega sua filha mata e estupra, ou qualquer lugar que seja. É muito difícil. Eu só peço para Deus para não acontecer isso com a minha. Porque a minha como estuda, eu tenho medo, eu tenho muito medo. Eu fiquei uma pessoa medrosa. Fiquei medrosa. Antigamente eu não tinha muito medo de andar na rua, tarde que fosse. Hoje em dia eu fiquei medrosa. Eu sou medrosa, não sou mais aquela pessoa que saía e não tinha muito medo. Hoje em dia as meninas também procuram muito, né? As minhas filhas não, graças a Deus as minhas filhas não. As meninas de hoje em dia. Arrumam uns caras para namorar que não... aí vão para os lugares e voltam tarde, né? Aí que correm perigo. Tem sempre que andar acompanhada. O pai buscar, ou a mãe, ou irmão mais velho. Porque andar sozinho é mais perigoso. Eu penso assim, apesar que...

4. Deixa eu te contar outra historinha. Uma criança chega no pronto-socorro com o braço quebrado e ai dizem que ela caiu da escada. Passa um mês e ela chega de novo no prontosocorro cheia de mancha roxa no corpo. O que você pensa?

Ou o pai ou a mãe que está batendo. Que negócio esse que menino cai direto e se machuca? Um menino que se machuca uma vez ou outra tudo bem, mas direto? Ou é o pai ou é a mãe, ou o tio, ou alguém da família que está espancando o menino. É violência. Uma pessoa, uma criança chega lá toda quebrada ainda chega com hematomas, o que a pessoa vai pensar? Toda semana uma coisa? É uma violência com a criança, eu acho. Porque tudo o que você falou é violência. O mundo hoje está, só é violência, você escuta só violência o tempo todo, né? O pessoal fala de desemprego, mas eu já não acho que seja desemprego. Não é porque eu estou desempregada que eu vou entrar numa vida dessa. Ou a minha filha, meu filho, o que seja. Eu acho que por aí não é o caminho. Eu acho que mais é as drogas. E tem muita amizade que influi. Influencia a outra, né? Vai passando, né? Eu sou colega eu faço. Eu penso assim. Por isso que esse mundo está assim. Não por causa de desemprego. O pessoal bota porque não tem emprego, mas não é assim, não é? Porque se todo mundo que não tem emprego fosse fazer coisa errada, como é que seria? Não é nada disso. Isso ai eu acho que é as amizades, as influências. E jovem, hoje em dia, a cabecinha não é igual como antigamente, né? $O$ que eles pensam? Pensam besteira. Eu acho que é mais a droga. Eu não sei menina, eu não entendo. Eu não entendo, tem uns meninos novos de 10,11 anos usando drogas, para que? Os pais nem sabem? Não é verdade? O pai e a mãe nem sabem. Vem para a escola, fala que vem para a escola, que vem para a escola nada, vai para outro lugar. Ou vem, fica, disfarça por ali um pouquinho e vai para outro lugar, não é assim? Assim que estão os meninos. E eu não sei por que. E hoje em dia os meninos têm mais coisas do que a gente antigamente. Tem roupa, tem brinquedo, né? Não sei. Eu fico olhando o jovem assim e fico pensando, o que tem na cabeça hoje em dia? Tem uns que tem a cabeça boa, mas tem uns que tem uma cabeça que só pensa besteira. Eu vou roubar, eu vou usar droga. E não é por aí, né? Não é isso. A mãe tem que incentivar muito, a mãe e o pai, né? Dar conselho. Acho que tem que ser por aí, né? Tem pai que dá conselho, que está sempre atento, 
e tem mãe que não liga. Tem mãe que não está nem aí. $O$ filho sai agora e volta de noite, de madrugada e ela não está nem aí. O filho chega com uma coisa em casa, um brinquedo, uma coisa, você arrumou isso onde? Quem foi que te deu? Não aceita e pronto. Não é assim. Tem saber a origem que deu, ir lá perguntar - você deu isso mesmo ao meu filho? Eu acho que aí você vai, né? Se o menino está começando errado, você vai começar, né? Tem mãe que não liga para os filhos, os filhos saem, voltam à hora que quer. Depois que virou a cabeça, para voltar a ser como era é difícil né? Graças a Deus eu não tenho esse problema. Eu não tenho. Ô. Tem uma com 15, tem com 19, meu menino tem 13 e a outra com 12. e graças a Deus, o único que é errado sou eu que fumo. $O$ cigarro, né?

5. Comerciante num bairro, cansado de ser assaltado, contratam seguranças particulares que identificam uns rapazes negros como sendo os assaltantes e matam os rapazes.

O que adianta? Não adianta nada. Está fazendo a mesma coisa que ele está fazendo. Porque o pessoal vai na delegacia, dá parte, mas não adianta. Por isso que o pessoal vai por esse caminho. Mas eu não sei, eu não acho certo. Ou muda, sei lá, mas tirar a vida. E está com essa sensação vai tirar, contrata os caras, está se igualando, porque está fazendo a mesma coisa, né? O pessoal não acredita muito na justiça, né? O pessoal não acredita muito hoje na justiça não.

6. Qual o papel do setor saúde na questão da violência?

Não sei o que falar sobre isso.

\section{Você tem alguma coisa que você queira falar mais sobre a violência?}

Causa violência? Eu não sei, viu? Porque o meu marido, o meu marido era um cara que bebia, e só bebia, ele não usava droga, ele nunca usou droga, mas quando bebia ele ficava bravo. Eu acho que o que leva muito isso é as amizades, porque tinha vez que ele estava aqui, os amigos chegavam e diziam, vamos beber, Fulano? E ele ia beber, sabendo que quando bebia ele ficava bem agitado. Ali para brigar para ele era um dois. Ainda para mim o que incentiva muito é as amizades. Porque tem amizade que não vale a pena você ter. Eu acho que você vai saber procurar as amizades hoje em dia. Eu acho, eu penso por aí. Teve menina que estava direitinho na escola, estava direitinho na vida dela, aquela coisa direitinho, se junta com as outras que não tem nada a perder, até tem, porque todo mundo tem, mas elas acham que não tem mais $e$, dali a pouco começa a ser igual a outra e assim vai indo. Eu acho que é as amizades e a droga. Se tiver é só isso, não tem outra coisa. Falta de Deus no coração, acho que não tem Deus no coração. Eu acho que é por aí, porque você ser pobre não é motivo para você ser ruim, né? Estar desempregado não é motivo para você ser ruim. Eu acho que as amizades mesmo, você anda junto se você quiser. Você não precisa seguir o outro, por exemplo, se eu sou errada, você é obrigada a me seguir. Mas tem gente que tem a cabeça muito fraca. Aí vai atrás. O que não presta. Aí começa a ir igual. Tem muitos que está faltando isso, está faltando aquilo em casa e faz assim. Quer ter mais coisas, quer igualar aos outros, deve ser por aí. Ai causa violência, né? Eu não tenho o que Fulano tem então eu tenho que ter igual, não é assim. Acho que é por aí. Eu acho, eu penso assim, você vê os jovens hoje em dia; antigamente, com 16 anos eles já trabalhavam. Hoje em dia você não tem trabalho, igual minha filha, ela é duro para trabalhar, porque não tem serviço para ela, ela tem 15. Eu acho que se arrumasse mais trabalho para esses menores, para esses adolescentes, eu acho que mudaria muito. Eles teriam alguma coisa para fazer e não iam pensar muita besteira. De noite ia para a escola e não tinha tempo para ficar pensando besteira. Eu acho que trabalho viu, para os jovens, eu acho que mudaria muito. Você vê um jovem levantar cedo, vai para a escola de noite e tem o dia todinho para ele andar, né? Andar, aprontar, então ele tem tempo. Eu acho que trabalho preencheria mais o tempo dele e não teria tempo para ficar andando na rua, andando com má companhia, eu acho que é isso. Eu acho que melhoraria bem. Você vê aquela rodinha de jovens, se todos tivessem trabalho e ocupação, não iam ficar naquelas rodinhas e ali começa a coisa errada, né? Eu acho que é por aí.

Quer falar mais alauma coisa? 
Não, não.

Muito obrigada pela sua ajuda.

\section{Entrevistado: T \\ Familiar de vítima de violência} Está bom?

Eu vou te contar umas histórias, se você acha que é violência, não é violência, e por quê.

1. Um trabalhador, voltando para casa, ele passa na frente de um bar, onde está tendo uma briga, aí se ouve um tiro e ele morre de bala perdida. Fala sobre isso para mim.

Ele estava chegando do trabalho e ia passando na frente de um bar que uma bala perdida acabou matando ele. É uma barbaridade, né? Ele passou na hora errada e é uma coisa que poderia ser evitada, se existisse, como falam muito dessa coisa de desarmamento, né? Se aquela pessoa que deu esse tiro não tivesse com uma arma, talvez não tivesse acontecido, né? Às vezes por causa de uma discussão boba, por causa de uma desavença qualquer, estão atirando à toa e às vezes isso acontece de tirar a vida de uma pessoa que não tem nada a ver. É isso.

2. Num bairro tem uma briga entre dois grupos para disputar o domínio de uma região. Aí, gente de um grupo é morta por gente do outro grupo. Fala para mim sobre isso.

Ah é um negócio complicado, né? É violência. Não deixa de ser. Às vezes, muitos, ou por sorte ou por desgraça, se encontram nesse grupo, né? Que seja de um lado ou de outro. Não deixa de ser violência.Eu acho que hoje você me pegou num dia que eu estou assim um pouco abafada para falar, as palavras não estão fluindo.

Você quer que eu volte um outro dia, ou a gente deixa isso para uma outra hora? adiante.

Não, eu acho que o que eu tenho para falar sobre esse assunto aí, eu já falei. Vamos

3. Então, vamos adiante. Uma moça, estudante, voltando para casa depois das aulas, é pega por um indivíduo que arrasta ela para um terreno baldio e a estupra.

Isso é uma violência tremenda, meu Deus do céu. Eu tenho uma filha de 13 anos e enquanto ela não chega, se atrasar 10 minutos eu já estou apavorada. Já estou preocupada, nossa, fica passando bobagem na cabeça da gente. E é uma coisa que a sociedade deveria se preocupar. Ter mais policiamento, mais segurança, né? Falam muito na televisão que tem guarda na escola, que tem isso e que tem aquilo e no final das contas a gente vê as coisas acontecerem a olhos nus, de dia, de noite, a qualquer horário e a gente não pode fazer nada. Tenta proteger pelo menos os filhos da gente. Não tem jeito. Tanto que eu tentei proteger o meu, mas dizem que quando Deus marca as coisas, quando tem que acontecer acontece, né? Não tem como evitar, né? Mas pelo menos a gente tenta, faz o que pode.

4. Uma criança é trazida no serviço de saúde com o braço quebrado e contam uma estória de que ela caiu da escada. Passa um mês e ela volta cheia de mancha roxa e com uma estória de que caiu da cama. O que você pensa sobre isso?

E ela continua agredida em casa? Provavelmente pelos próprios pais. Isso deveria não existir, mas a gente sabe que existe, né? Essas pessoas deveriam ser mais punidas. Deveria ter 
mais punição para esse tipo de, é uma violência, mas não deixa de ser um crime também. Uma pessoa indefesa, a quem eles deveriam proteger, eles espancam.

5. Comerciantes num bairro, estão cansados com a onda de assaltos e aí resolveram contratar uns seguranças particulares por conta própria. Esses seguranças identificam uns rapazes negros que seriam os que estavam assaltando esses comerciantes e matam esses rapazes.

É uma violência também, né? Eu acho que não deveria ser dessa forma. Deveria ser, contrata uma pessoa para descobrir quem estava fazendo e chamasse a polícia para resolver.

\section{Qual o papel do setor saúde na questão da violência?}

Aí é complicado. Eu fui parar no pronto-socorro desses que os médicos ficam entre si, batendo papo na sala ao lado, aquela multidão de gente esperando para ser atendido, uns com febre, outros com dor, criança que chora. E eles na sala reservada batendo papo. Nesse dia eu estava com a minha filha lá e, eu acho que tinham umas 20 na minha frente, e a minha filha estava já com quase $40^{\circ}$ de febre, e se demorasse mais ela tinha convulsão. Eu via que ela ia ter e não podia fazer nada. Então, nesse dia eu me desesperei, fui lá na sala que estavam os médicos conversando, peguei um pela abertura e levei onde estava a minha filha, gritei, fiz um barulho e pedi por tudo que era mais sagrado que ele atendesse a minha filha. Ainda bem que ele atendeu, quando ele começou a atender ela já começou a ter a convulsão, mas aí foi controlado e sorte que estava só no início, né? Então nessa situação dessa pessoa aí, é chamar por Deus mesmo. Chamar por Deus e tentar fazer...é complicado. Pedir ajuda.

7. Só para a gente terminar, você tem alguma coisa que você queira falar sobre o que você acha que é a origem da violência, sobre a violência, sobre formas que se pode mudar a situação?

Não, é, violência, a violência é muito complicado você... você vê que o governo entra e fala que vai fazer e acontecer e acaba não, todo mundo tem a solução, a fórmula de resolver, só que acaba que ninguém consegue resolver, né? Eu acho que deveria ter mais incentivo à educação, incentivo aos jovens, que são o futuro do nosso País, e com um pouquinho de boa vontade política e ajuda à população mais carente, eu acho que ajudaria. Educação, lazer, essas coisas.

Muito obrigada, viu T.

\section{Entrevista L \\ Formador de Opinião}

1. Um trabalhador, voltando para casa, ele passa na frente de um bar, onde está tendo uma briga, aí se ouve um tiro e ele morre de bala perdida. Fala sobre isso para mim.

Ele é vítima, né mas naturalmente ele é conseqüência da sociedade contemporânea. Ele na realidade a partir do momento que passa em frente ao bar e leva um tiro, ele vive naquele contexto, ele faz parte daquele contexto, ele não está passando ali na grande maioria dos casos acidentalmente. Ele tem uma referência com aquele local, portanto acho que ele é uma vítima da sociedade contemporânea. Que envolve tanto as pessoas que estavam lá, como este que estava passando no local.

2. Então, vamos adiante. Uma moça, estudante, voltando para casa depois das aulas, é pega por um indivíduo que arrasta ela para um terreno baldio e a estupra

Ė uma barbárie, né. Ė até difícil de comentar uma situação dessa. Eu acho que talvez, dos crimes, este seja um dos piores, que envolve crianças e adolescentes. No pricípio, salvo engano, são pessoas, são inocentes, que não têm poder de reação frente a esta criminalidade. São as maiores vítimas da violência. Tem violência e tem criminalidade, são duas coisas distintas. Então 
eu acho que como comentei no primeiro caso ela é mais um integrante da sociedade que é vítima do meio onde ela mora

3. . Num bairro tem uma briga entre dois grupos para disputar o domínio de uma região. Aí, gente de um grupo é morta por gente do outro grupo. Fala para mim sobre isso.

A maioria das pessoas que moram nos bairros acham que isso não é violência, acham que isto é uma briga entre gangues, que isso faz parte do cotidiano, e isso é uma coisa que assusta. Isto também demonstra que as pessoas estão se habituando com a violência e com a criminalidade. Isto não deixa as pessoas mais indignadas. Isso eu já ouvi, mas também é uma falha da , do sistema nosso policial, de prevenção, da impunidade sobretudo, da demora da justiça e o que é pior, é a falta de ocupação de um espaço pelo poder público. Tem-se demonstrado em várias ações que a gente tem, como os barracões culturais, esta falta de ocupação do espaço, pela autoridade pública, seja é um dos fatores que induz a ocupação destas áreas para o crime,para criminalidade, por gangues, por conflitos. Eu acho que o poder público é territorialmente, ele está concentrado sobretudo nas camadas sociais com maior poder aquisitivo, com melhores condições. Estes rincões no território, sobretudo metropolitano, vira terra de ninguém.

4. Uma criança é trazida no serviço de saúde com o braço quebrado e contam uma estória de que ela caiu da escada. Passa um mês e ela volta cheia de mancha roxa e com uma estória de que caiu da cama. O que você pensa sobre isso?

Tem que ser apurado. Tudo isso é pelo menos suspeito.Nos induz a imaginar, com a freqüência que esta criança vem ao pronto socorro e é atendida com estes traumas, ele pode está sendo vítima também da violência doméstica e por conseqüência, é um desdobramento da violência urbana, da violência da rua, da violência do cotidiano, que é induzida de várias formas né, pela mídia,pela televisão, pela cultura americana que nós recebemos. A cultura americana que está enraizada hoje no mundo e sobretudo no Brasil, é a cultura da violência. As pessoas buscam a paz através da guerra. Quer uma dicotomia maior do que esta? Com este discurso do poderio e eu acho que isso é uma conseqüência da violência urbana.

5. Comerciantes num bairro, estão cansados com a onda de assaltos e aí resolveram contratar uns seguranças particulares por conta própria. Esses seguranças identificam uns rapazes negros que seriam os que estavam assaltando esses comerciantes e matam esses rapazes

Também não é correto. A segurança é uma atribuição do estado.Ela, não se deve e nem se pode fomentar iniciativas desta natureza. Atuar de forma preventiva é correto. Você tem outros meios, agora uma reação a esta violência que nós vivemos, com os mesmos instrumentos dela, acaba gerando mais violência. É o conflito e isso não deve acontecer. Mais uma vez é a ausência do estado, no que diz respeito a esse serviço público de preservar a liberdade, o direito de ir e vir, de compra, da família e assim por diante.

\section{Qual o papel do setor saúde na questão da violência?}

Primeiro atuando efetivamente, de forma competente e justa. Atuando lá no bairro,no território. Acho que os agentes de saúde são um instrumento extremamente importante, que mostra efetivamente que o poder público, o estado está lá. É um meio de pesquisa, de detectar a violência doméstica. Por exemplo a criança, acho que o serviço de saúde pode por um trabalho nesta linha. Primeiro detectar e segundo o trabalho com a familia, através de psicólogos e assim por diante. Pode ser um distúrbio emocional, problemas familiares, desentendimentos que geram a isso, a pessoa instável. Eu acho que a saúde tem um papel importante nisso

7. Só para a gente terminar, você tem alguma coisa que você queira falar sobre o que você acha que é a origem da violência, sobre a violência, sobre formas que se pode mudar a situação? 
Eu acho que a sociedade de consumo é um instrumento que leva sobretudo o jovem, o adolescente, o induz a criminalidade. O que se prega hoje na mídia, na sociedade contemporânea é que as pessoas para serem incluidas na sociedade têm que ter o carro do ano, o relógio moderno, a roupa de grife, e isso é colocado pela mídia pela sociedade de consumo que nós vivemos. Estão perdendo a dimensão humana das ações sobretudo públicas. Você abre os jornais e só se discute a taxa de juros, só discute economia, a importação, mas os problemas sociais ... O que as pessoas também não conseguem ver no cotidiano é que elas são vítimas da violência no dia a dia e não percebem. Quem não tem o transporte adequado para chegar ao trabalho, isso não deixa de ser uma violência contra o cidadão, que tem direito de ir e vir. Quando ele não tem condição, não tem saneamento básico é um instrumento da violência, quando ele é vítima da especulação imobiliária e compra um terreno que foi valorizado através de um investimento público, ele também é alvo da violência. Este tipo de violência, eu acho que a sociedade ainda não se ateve.Quando o cidadão vai lá no pronto socorro e ele é atendido por uma pessoa de segunda categoria, ele está sendo vítima da violência, não é só a violência da criminalidade mas uma violência da própria sociedade impõe sobretudo aos mais necessitados, é uma exclusão e isso se dá de forma, não seria oculta e sim silenciosa que as pessoas não percebem. Acham que a violência é a criminalidade mas a violência não é só a criminalidade. Isso me incomoda muito. As pessoas ainda não perceberam isso. Mas sobretudo, isso é colocado de forma ideológica, sempre foi assim, não se tem vontade de mudar isso.Então eu acho que esse tema é muito pouco abordado. As pessoas têm um pouco de receio de mexer nisso. Está enraizado na cultura da sociedade contemporânea, sobretudo aqui no ocidente, Estados Unidos onde o consumo ............ as ações não só da sociedade como também de governo. Só uma mudança cultural e de educação para mudar, para abrir os olhos desta geração que está porvir. Você hoje mudar isso... Um governo não muda mas ... Isto é através gerações. Mas as pessoas precisam começar a ser alertadas para isso. O mundo não é assim, o mundo não é dividido entre ricos e pobres, é dividido porque a sociedade assim coloca, mas a pessoa não é pobre porque D'us quer que seja pobre. Ela é pobre em função de uma série de atores que atuam em uma sociedade. São excluídos.Acho que isso as pessoas tem que começar a plantar. Agora, vamos pegar o Brasil né,nós ficamos muito tempo sob égide da ditadura. As pessoas não podiam se pronunciar, tivemos o desmonte do sistema educacional,não tinha um projeto de país, Tudo isso hoje é uma conseqüência, conseqüência de uma série de desmontes durante anos e olha, isso é uma pergunta: Será que no Jacira a violência algum dia foi menor do que é hoje? Será que hoje a violência e a criminalidade não estão em pauta porque chegou na classe média? Se não chegasse na classe média dos formadores de opinião, as pessoas não estariam preocupadas com a violência, ela chegou hoje, ela consta hoje como prioridade de governo, de aspiração da população porque chegou na classe média, enquanto o cidadão estava lá no Jacira morrendo, sem escola sem um médico,poucos estavam preocupados com isso, mesmo a mídia. Hoje que chegou onde chegou, no Jardins, chegou em Higienópolis, na Paulista, em uma série de lugares, que incomoda aos formadores de opinião, classe média, mídia, imprensa. 


\section{Entrevista: padre 0. Formador de Opinião}

1. Um trabalhador, voltando para casa, ele passa na frente de um bar, onde está tendo uma briga, aí se ouve um tiro e ele morre de bala perdida. Fala sobre isso para mim.

Violência. Aí entra o aspecto da responsabilidade para com o outro. $O$ que você faz não tem incidência só na sua vida ou só naquele que está aí. Isto tem conseqüências as vezes distantes tanto no tempo quanto no espaço para atingir quem estava desconexo daquela situação. Estava fora mas também sofreu os efeitos de um ato de violência.

2. Então, vamos adiante. Uma moça, estudante, voltando para casa depois das aulas, é pega por um indivíduo que arrasta ela para um terreno baldio e a estupra

Violência que já beira a psiquiatria. São resultado de processos já complexos. Desvios do indivíduo de vários aspectos. É bem mais complexo e também um ato de violência.

3. . Num bairro tem uma briga entre dois grupos para disputar o domínio de uma região. Aí, gente de um grupo é morta por gente do outro grupo. Fala para mim sobre isso.

Uma violência já generalizada. Este caso já demonstra uma violência que atingiu todo o campo social. Ela generalizou tomando o caráter de pequenas revoltas civis já. Já envolve a questão de drogas, de interesses, de comandos. Envolve aí a sobrevivência. $O$ traficante acredito, não trafica só porque ele é dependente; muitas vezes ele não é. Isto se torna muitas vezes um meio de vida e ai entra a questão da sobrevivência e aí está um problema mais profundo que merece um trabalho acho assim bem detalhado. Sobrevivência. Quem não luta por ela?

4. Uma criança é trazida no serviço de saúde com o braço quebrado e contam uma estória de que ela caiu da escada. Passa um mês e ela volta cheia de mancha roxa e com uma estória de que caiu da cama. O que você pensa sobre isso?

Uma situação que deve ser analisada. Acredito que o organismo possa ter tido alguma reação natural que fizesse estas manchas roxas, porém pode ser resultado de que estivesse brincando na escada e levou uma surra por causa disso. Então é questão de se analisar mesmo, de ir atrás da história. Não sei se me fiz entender. De repente ela voltou para casa e está lá em cima da escada; levou uma surra e está roxa devido disso ou acredito que o organismo depois de algum tempo possa... Eu mesmo já tive manchas roxas e as vezes é conseqüência de um momento, uma emoção, de um momento mesmo de sua vida. É relativo.

5. Comerciantes num bairro, estão cansados com a onda de assaltos e aí resolveram contratar uns seguranças particulares por conta própria. Esses seguranças identificam uns rapazes negros que seriam os que estavam assaltando esses comerciantes e matam esses rapazes

Bem, pelo menos três coisas eu vejo que estão envolvidas. Começando pelo último, preconceito. Entrou a história do preconceito. É negro então já é uma caracterização do crime, do roubo, do assalto. $O$ outro aspecto é o da violência mesmo. Então ele quis resolver a violência com violência. Sabemos do resultado disso. E um terceiro e último aspecto é o de tentar resolver a violência imediatamente, pelo caminho mais fácil. Mas por um caminho que normalmente não dá resultado porque a violência não é uma questão só, no meu modo de ver, de ser inibida, mas de ser evitada. É uma questão, como se fala na saúde, de prevenção. Deve ser prevenida e não remediada. É um aspecto muito interessante sobretudo de políticas públicas. Trabalha-se até bastante no remediar, no controlar, no reprimir a violência mas falta muito ainda trabalho de educação de filhos, de família, incutir, transmitir, eu sei que incutir fica muito forte mas transmitir valores para as famílias. Educar os desvios. Entram vários outros aspectos também. Hoje fica-se 
discutindo a televisão, por exemplo. A violência na televisão. Como ela influi na violência futura de um jovem. É aquela coisa. Discute-se o sim e o não e parece uma discussão eterna e não se chega a uma conclusão para fazer o trabalho. Eu tenho também, já que você está apresentando casos um caso do lçami Tiba, "quem ama educa". Ele conta a história de uma jovem de 16 anos que conheceu outro jovem, começou a namorar. Os pais perceberam que o jovem tinha problemas com drogas; era muito bom de papo, sempre estava com roupinha muito bonita ,no entanto não tinha nenhum ganho, não tinha nenhum salário e foram percebendo toda a situação. A menina descobriu que ele estava se drogando e já apaixonada foi morar $\mathrm{c} /$ ele. Foi morar $\mathrm{c} / \mathrm{ele} \mathrm{pq}$ tinha a idéia dela, a fantasia do amor, da aventura "vou salvar ele, vou morar $\mathrm{c} /$ ele". Foi morar c/ o jovem. Os pais prevendo um pouco as coisas, grampearam o telefone celular dos dois e descobriram que este jovem estava planejando o seqüestro da filha que era de familia classe média alta. Estava planejando o sequestro dela. E o que eles fizeram? A polícia os pegou num fórum de computador que são estas salas que tem na Internet, e eles estavam consultando um videogame que simulava seqüestros. Ali ensinava todos os pontos que tinham que pensar se fosse de verdade e ali foram flagrados e presos. Depois aconteceu o inquérito e se descobriu tudo isso. Então, aquele vídeo game unido já a uma pretensão para o mal, um projeto de maldade, foi um grande incentivo. $\mathrm{E}$ estes casos ainda não convencem as pessoas que têm um efeito. Então a televisão continua sendo violenta, os pais estão perdidos com a educação hoje, muitas vezes. O mundo mudou muito e os pais ficam perdidos mesmo.Tem pais aí que perguntam "o que que eu faço?" e este o que que eu faço já é para mim o desespero. O que que eu faço? A mudança cultural é tão grande que ele não sabem o que fazer. Conclusão de tudo isso: se em casa não tem limite, socialmente não vai ter. Então é onde desemboca também a violência, onde se conclui casos como este aí.

\section{Qual o papel do setor saúde na questão da violência?}

Bem, serviços de saúde, como poderia contribuir para a redução da violência? Tem um papel, porém vejo que estão muito longe disso. A saúde é tratada em pontos localizados. A pessoa está com problema de dor de ouvido, então dá antibiótico para melhorar a dor de ouvido. No entanto, aquela dor de ouvido que precisa certamente de um antibiótico pode ser resultado de uma vida de tensão, do desemprego, de uma situação emocional muito complicada. Então o tratamento se dá num ponto localizado, no entanto, eu to pegando só um exemplo, o problema de saúde pode ser resultado de várias situações que a pessoa está vivendo, então como que a saúde pode contribuir para reduzir a violência? A partir do momento em que a saúde de uma pessoa for tratada como um todo. Se pensar na saúde da pessoa e não no ouvido, no problema de estômago. Pensar a saúde da pessoa. Neste sentido, fazendo estes trabalhos com a familia seria positivo pois já é um caminho para esse todo.Porque você vai entrar em questões que envolvem o seu grau de violência ou não. Porque a violência não nasce de um minuto para o outro. Porque se os filhos vêem os pais sendo violentos no falar ou no brigar o que é pior, dentro de casa, isso já é um estímulo para que ele cresça pensando que vai resolver seus problemas usando de violência. Então ela é um processo lento, demorado e complexo.

7. Só para a gente terminar, você tem alguma coisa que você queira falar sobre o que você acha que é a origem da violência, sobre a violência, sobre formas que se pode mudar a situação?

Tem sim. Apesar de, repito, o assunto ser complexo, merecia uma conferência só sobre ele, mas tem aspectos que considero muito importantes e um deles é isso que falei: trabalhar a pessoa como um todo. Isso eu tomo como religião, como saúde, como política. Todos os âmbitos da sociedade. Nós estamos assim um pouco viciados a tratar as pessoas só em alguns aspectos. Precisamos repensar esta questão como um todo. O ser humano como um ser complexo e que merece desdobramentos. Como um ponto é isso, tratar a pessoa como um todo. Outro ponto vem por exemplo na educação. Escola. Tem incidência direta no futuro de uma sociedade, violenta ou não. Então na educação deveria se tratar desta questão mais profundamente considerando vários aspectos.Eu escrevi um artigo por exemplo a uma jovem que me escreveu perguntando o seguinte: Padre, como é que Dús permite um acontecimento como aquele na Rússia, na escola, que foi um acontecimento tenebroso de violência. $E$ aquela pergunta tão curta me deixou muito encucado. $E$ tentar responder. Lendo um artigo inclusive de uma americana, eu comecei a ler a 
reflexão dela e procurei responder. $\mathrm{O}$ que aconteceu? D'us sofre muito com um acontecimento deste. D'us sofre muito com um ato de violência. Então se a gente pensar na sociedade que estamos criando, nós caminhamos cada vez mais para a violência. Um exemplo: você pode ficar justificando que no passado a bíblia, a palavra de D'us foi usada para fazer violência. Mas isso seria só julgar o passado. Na escola se tirou a bíblia. Não se pode ler mais a bíblia porque tem a questão das religiões. Então tem que se respeitar todas e em nome deste respeito a todas não se fala de nenhuma ou não se fala daquilo que é comum. Até pouco tempo o estado de São Paulo era a expressão disso. Não tinha uma educação religiosa. Nós tentamos retomar isso. Então se tirou por exemplo a bíblia da escola e se alguém tenta ler é logo rechaçado. E é a bíblia que fala de amor, respeito ao próximo, de não violência, de caridade.Se tirou. Depois vem outra pessoa e fala assim: Ah, vamos passar na televisão filmes de violência. Alguém responde, mas isso prejudica o jovem, isto é um estímulo para a violência. Vem outro e : "não, isso é só uma ficção, não sei o que, não tem nada de conseqüência" e o que nós fazemos? Estamos convencidos que realmente não tem nenhum problema. Daí a pouco vêm distribuir revistas com homens, mulheres nus, desfilar os corpos nas revistas. Vem alguém da sociedade que é considerado conservador e critica, alguém já defende: Isso aí é só para ver, observar, não significa nada. Isso aí é só um passatempo, um lazer e assim por diante. Vamos dando várias desculpas para coisas que no fundo implica no seguinte: Não se tem limites. Eu falei um pouco da questão da família, que é fundamental também. É na família que pais colocam limites para filhos. Nós estamos criando uma sociedade sem limites. Sociedade sem limites, violência sem limites. Então nós temos que repensar muita coisa na educação, sobretudo educação escolar, educação religiosa e a alegria da gente é ver muitas pessoas trabalhando neste sentido. Não podemos dizer que ninguém está fazendo nada porque muitos educadores tanto na área escolar como na religiosa que já deram passos adiante e repensaram a questão da educação religiosa, educação pública e assim por diante.

\section{Entrevistado: D. Protagonista da violência}

1. Olha, eu vou te contar umas historinhas, você vai me falar se você se essas são historinhas de violência ou não e vai me falar o que vier na sua cabeça com essa historinha: Um trabalhador esta voltando pra casa passa na frente de um bar onde está acontecendo uma briga, houve - se um tiro e um homem cai morto com uma bala perdida, fala sobre isso.

Isso é normal acontece em todos os cantos gente que toma tiro de bala perdida, está passando e não tem nada a ver com a história, isso pra mim esta acontecendo em todos os cantos todo mundo está arriscado a morrer, pode ser eu ou você, está dentro de um carro, vem um tiro não sei da onde e acerta em você, em mim, na minha mãe em qualquer pessoa, acho normal isso daí.

2. Uma estudante voltando da escola é atacada por um indivíduo que arrasta ela para o mato e estupra ela.

Tem louco pra tudo né, uns gostam de roubar, outros gostam de matar e outros gostam de estuprar. Tem gente que tem maldade pra tudo na cabeça, isso daí eu não acho muito certo, aliás, nenhum bandido gosta disso ai de estuprar uma aluna que esta vindo de um colégio, eu acho que pra mim...(incompreensível)

3. Um bairro tem uma briga de dois grupos pelo domínio da área, gente de um grupo mata pessoa de uma outra turma.

Isso que acontece mais, tipo assim eu moro numa periferia e a pessoa mora em outra, por exemplo, duas bocas não se dá, que é duas biqueiras, e ai uma fica na maldade com o outro, o que dá mais morte em salão e por causa disso, por causa de que todo mundo vai pra boate e vai 
neguinho de uma boca e vai de outra favela, ai se tromba e onde que um mata o outro, por causa de droga essas coisas.

Fala mais sobre essa questão.

E ai eu tenho dez amigos que eu moro numa favela, nóis tudo sai junto, tem outra favela que sai com mais dez amigos e ai um vai e mata um de nóis que e amizade, a gente não vai deixar quieto, a gente estamos falando dos malandros, não vai deixar quieto vai lá e mata o outro, ai o outro não vai deixar quieto vai lá e mata o outro.

E onde e que isso pára?

Até acabar, não pára aí que está porque uns vão morrendo e outros vai entrando, nunca para, só vai morrendo gente, igual aconteceu mesmo aqui uma pá de gente morreu, já morreu o dono e já morreu não sei quantos donos, e mesmo assim vai morrendo e aí vai indo, um vai morrendo e outro vai assumindo, nunca acaba não.

4. Uma criança pára no pronto-socorro com o braço quebrado e uma história que caiu da escada, um mês depois ela volta no pronto-socorro com mancha roxa pelo corpo.

Isso dai já acho que é problema de família, dos pais bater, lá em casa já aconteceu isso já, eu tinha uma sobrinha e a minha prima ficava batendo nela, você corria para o pronto-socorro e falava que ela tinha caído da cama, essas coisas, e apesar de que hoje ela deu a minha sobrinha num orfanato, a minha tia foi lá e tirou e está criando ela, essa minha sobrinha não vale nada, apesar de que a minha tia também não vale nada porque ela podia chegar e...(incompreensível) pra cá e tal, e hoje a minha sobrinha está bem só que esta revoltada com a mãe, quando uma chega a outra sai. É, é capaz dela virar a cabeça mais tarde, querer fazer isso com a filha dela, ficar com mágoas, mas eu acho que agora minha tia está dando educação pra ela e explicou tudo, a pessoa que sofre quando é criança, nunca desejo isso pra ninguém quando vai crescer aí não tem...(incompreensível), acho que é complicada essa história.

5. O comerciante de um bairro cansado de ser assaltado contrata uns seguranças particulares, esses seguranças matam uns rapazes negros que foram apontados como sendo os assaltantes.

Isso acontece demais, outro dia eu estava no salão, arrumaram uma briga comigo por causa de um comerciante, o cara disse que eu tinha roubado ele de madrugada e quem tinha roubado era um branco esse bar, e esse rapaz tinha acusado eu e um amigo meu que é moreno, mas moreno mesmo, neguinho mesmo e não tinha nada a ver, o rapaz falou que tinha sido ele, de dia ele teve preso e eu tava junto e eu fui também, só que depois que eu vi quando gente que roubava, isso é um racismo total, só porque o rapaz era preto, e não fez nada, só acusou porque era preto mesmo, com uma cara de...Sei lá o que o pessoal tem contra os negros, é capaz que os brancos hoje em dia apronta mais que os pretos se todo mundo for ver, não vejo não o cara preto que já matou, o cara preto que já rouba, aqui mesmo não acontece, só acontece cara de branco, acho que isso também é errado, acusar gente preto, ninguém pode acusar ninguém, tem que ver.

6. Você acha que os serviços de saúde podem ajudar como a diminuir a violência, tem alguma papel que os serviços de saúde pode desempenhar para diminuir a violência?

A violência eu não acho tanto não, mas pra ajudar gente que mora na favela, eu acho que isso pode ajudar muito, agora sobre a violência de rua não tem como ajudar.

E como é que você acha, no que você acha que pode ajudar?

Acho que pode, como eu vejo você que trabalha no Gilson, todo mundo trabalhando de casa em casa batendo no portão pra ver como é que está a saúde das crianças, ajudou muito aqui 
em Parque Parisi, agora a policia tinha que fazer as partes dela, ir atrás pra tentar resolver os problemas, se a polícia fosse como vocês de ir atrás pra resolver os problemas dela mesmo, aliás, a polícia sabe onde está os problemas só que eles não resolve, eles não resolve, eles só passam e ver, mas se eles chegassem mesmo pra resolver os problemas ai estava todo mundo resolvia. Porque polícia é estudado pra isso, pra ir atrás de ladrão, eu acredito que já entrou pra isso e já entrou pra isso porque é que não resolve, eles são treinados pra resolver e não resolve.

7. Tem mais alguma coisa que você gostaria de falar sobre a questão da violência, você estava me falando antes da gente vir pra cá que você teria muito que falar sobre a história da periferia, da violência.

É eu tinha pra falar de eu mesmo sem você perguntar, o que eu acho da violência onde eu moro, onde eu moro não esta nem tendo muita violência, mas já aconteceu uma violência comigo de tomar tiro, essas coisas; já tomei caso de mulher, essas coisas que acontece; já tomei tiro e passei mais de um mês internado, só no caso que eu disse de uma menina que não tinha nada a ver, eu não sabia que ela tinha namorado, o cara ficou sabendo chegou e atirou em mim, só que eu não morri, e a violência aqui onde eu moro em parque Paraibuna já foi mais avançada, hoje esta mais calma.

\section{O que você acha que aconteceu pra mudar isso?}

Eu acho que nem foi pelas polícias que mudou isso, eu acho que a pessoa que começa a acomodar, tipo o Parque Paraíso, começa a acomodar esse negócio de banco, essas coisas, eu acho que esse é um cara mais sério, se ele souber que o cara está roubando um comerciante ele vai atrás, se ele souber que o cara está matando uma pessoa por maldade ele vai atrás, se ele souber que alguém está roubando pai de família ele vai atrás, eu acho que mudou mesmo por causa desse cara que entrou agora, ele está mudando mesmo, ele é o cara que quer saber tudo certinho que está acontecendo, igual este ano novo, este natal agora mesmo, ele comprou uma Van cheia de panetone e distribuiu pra todo mundo, no natal ele fez a mesma coisa, distribuiu cesta básica pra todo mundo e agora ouvi falar que ele vai distribuir cesta básica pra todo mundo que está precisando também. Eu acho que esta mudando, é isso. Se fosse um cara mais ruim não estava nem ai, deixava todo mundo fazer...E ai virava bagunça total, eu acho que esta mudando por isso, e muito. Que igual na escola lá embaixo, todo mundo ia roubar, cobre as molecada, e estava começando a mexer na escola, ele ficou sabendo, descobriu quem era as mães dos meninos e foi de casa em casa falar com elas, e hoje ninguém mexe mais na escola, ninguém picha, ninguém quebra vidro, ninguém faz nada.

\section{E ele é quem comanda a boca?}

É ele que comanda tudo, pra dizer a verdade eu nem sei quem é entendeu? Quem comanda mesmo não fica aqui, os outros é que trabalha pra ele, ai acho que está melhorando, agora se for pôr polícia não acho que melhora não isso eu falo pra você, porque polícia, o certo seria educar, ensinar a educar, eles pegam uns meninos que não tem nada a ver, os moleques que nem rouba, trabalha, dá tapa nas orelhas dos meninos, bate, dá cacetada, os meninos se revolta e começa a ficar revoltado com polícia, qualquer coisa que vê, a polícia já começa a xingar, depois apanha e perde a moral e começa a roubar pra fazer vingança com a polícia, eu já passei por isso mil vezes só que graça s a Deus eu não entrei nisso não, não compensa também entrar em confronto com a polícia, o que eu acho é isso.

Obrigado. 


\section{Entrevistado: $\mathbf{N}$ \\ Protagonista da violência}

1. Olha eu vou te contar umas historinhas, você vai me falar se você se essas são historinhas de violência ou não e porque: Um trabalhador esta voltando pra casa passa na frente de um bar onde esta acontecendo uma briga, houve - se um tiro e um homem cai morto com uma bala perdida, fala sobre isso.

Acho que não é uma violência no modo de dizer assim, porque acho que ele passou no lugar errado, na hora errada, uma violência é quando o pessoal esta no bar acontece um tiroteio o pessoal assassina, e acontece duas ou três mortes ai e uma violência entendeu, mas ele passou no lugar errado, na hora errado. Esta acontecendo muito porque hoje não tem mais vagabundo no crime, a criminalidade hoje mudou, vou te dizer eu tenho 18 anos no crime e a bandidagem não é igual antigamente, porque antigamente se você visse um pai de família passando fome você ajudava ele, hoje não você vê os vagabundos tirando dinheiro de pai família, tirando a vida de pai de familia.

\section{Mudou a ética, fala mais dessa historia.}

Hoje é por causa mais da droga entendeu, a cocaína e crack estão acabando com a sociedade, a maconha nem tanto, quem usa maconha e mais da sociedade, é assim pai de familia que pega assim $R \$ 5,00$ ou $R \$ 10,00$ e passa uma semana, agora cocaína não, se você começar a cheirar hoje com menos de $\mathrm{R} \$ 100,00$ você não vai parar, então você não tem $\mathrm{R} \$ 100,00$ pra cheirar todo dia. O crack você rouba sua mãe entendeu, você vende tudo dentro de casa pra usar droga, e se você não tem aquela droga então você mata qualquer um não pela droga, mas pelo medo que você sente, eu já usei crack fiquei 4 anos viciado, tinha hora que eu tinha medo da minha própria mãe, eu achava que ela ia chamar a policia pra mim, eu tinha vontade de matar ela, de matar alguém dentro de casa por medo, não porque eu tinha vontade mas por medo que eu tinha, pra mim já era um inimigo, eu usava aquele tanto assim e falava nossa eles vão matar eu, mas falava tudo bem para com isso, para de usar droga então eu me sentia uma coisa que só Deus mesmo, agora muito amigos meus não conseguiram sair do crack. Foi Deus vi, eu fiz uma promessa pra Deus que se eu parasse de usar eu parava de vender ele, e ai Deus me tirou do crack e eu parei de vender porque eu vendia muito crack, e ai Deus me tirou desse vicio, falei como deus me tirou desse vicio quero que muitos saem também entendeu, ele me libertou disso daí, eu tinha um sonho de que todo mundo usasse, pra mim a melhor droga é a maconha, se todo mundo fumasse maconha você não via violência, você não via nada de mal, eu fiquei dois anos presos e na cadeia eu trafiquei entendeu, tanto e que a cadeia eu colocava três tipos de droga pra dentro, quando chegava à semana eu colocava a maconha, então não tinha fuga, não tinha briga, não tinha nada, na outra semana colocava o crack, quando todo mundo começava a comprar e fazer dividia que não tem dinheiro pra pagar, era dois morto, era com facada, muita coisa acontecia na cadeia por causa do crack e da cocaína, quando entrava essas duas drogas na cadeia você cia o que um inferno a cadeia, quando tem cocaína e tem crack na cadeia vira um inferno, é morte, é briga é facada, e quando entrava só maconha ninguém brigava, um sentava do lado pra fazer um artesanato, outro fazia uma cortina entendeu, cada um fazia alguma coisa para o tempo passar, e a cocaína não você acabou de cheirar você quer matar um inimigo seu que esta lá dentro só porque a sua cabeça esta agitada, não esta sabendo o que esta fazendo, no outro dia você sara e fica uma desgraça.

2. Uma estudante voltando da escola é atacada por um individuo que arrasta ela para o mato e estupra, fala sobre isso.

Isso daí é uma coisa muito triste que nos que é vagabundo não aceita entendeu, a coisa de um crime que não tem onda, que não tem significado porque esse artigo ai é o pior que tem, ou na rua ou na cadeia, cara que faz isso ai pra nós não é homem não, a sentença dele é a morte, ai nos 
mesmos faz a violência entendeu, não espera nem a sociedade vai fazer, nos mesmos que somos criminosos já não dá um ponto pra isso, nossa sentença pra isso é matar quem faz isso.

3. Num bairro tem uma briga de dois grupos pelo domínio da área, gente de um grupo mata pessoa de uma outra turma.

É uma violência, porque pelo grupo ai através estão brigando através de dinheiro ganância ou do jogo entendeu, então eu acho que e uma violência através da ganância, olho gordo porque pelo certo mesmo do crime não se pode ficar discutindo entre os criminosos, se controla o crime através de dividir então sobra pra todo mundo, então todo mundo no crime tem que sobrar um pouco, não precisa matar o neguinho pra ser criminoso entendeu, então hoje a violência esta assim através da ganância.

Fala mais sobre essa questão.

Antigamente quando nos quando era parceiro de moleque em assalto nos roubava um cofre que tivesse assim $R \$ 20.000$, era $R \$ 5.000$ pra cada e hoje não, se tem um assalto muito parceiro nosso quer matar a gente pra ficar com o dinheiro, eles não interessa em se associar vamos dividir um pouquinho pra cada, hoje o que esta fazendo a violência é o próprio dinheiro mesmo entendeu, porque hoje quase ninguém quer dividir o que tem, e acabar com o outro pra ficar com ele sozinho, e o que estou vendo hoje aqui.

4. O comerciante de um bairro esta cansado de ser assaltado, resolve contratar uns pé de pato, ai os pé de pato mata os mocinhos que eles identificam que eram os moços que estavam assaltando o comerciante.

Ai o comerciante agiu errado, que pelo certo disso ai não e contratar os pé de pato, é conversa com os pessoal mais velho da área, os traficantes, ver os ladrão bom que moram ali entendeu, e através dali eles mesmo fazer a corrida não deixar ninguém matar, porque eles mesmo pega e dá um sumiço entendeu, porque se ele contratar alguém de fora pra matar, então nunca tem respeito, quem mora na área nunca dá valor, nunca tem o respeito, então o certo mesmo é o pessoal da área os traficantes ou uns bons ladrão que tem na área não deixar acontecer roubo na área, porque na área que a gente mora mesmo não pode ter essas coisas, então através disso que você vê que sai a violência, porque os ladrãozinho não tem coragem de roubar fora fica roubando na área, ai quando vem a policia eles se escondem, e nos que já temos o nome no crime nos é pego pela policia, ai e obrigado nós mata eles pra não ficar com o nome sujo entendeu.

5. Uma criança é levada para o pronto socorro com o braço quebrado e uma historia que caiu da escada, um mês depois ela volta no pronto socorro com mancha roxa pelo corpo e uma historia de que caiu da cama, o que você acha disso?

Foi espancada, e os pais e familiares pegou ela, somente padrasto e madrasta que faz isso espancar as enteadas, fui criado com madrasta eu sei o que é isso, muito espancamento, então nos antigamente ainda agüentava, jamais levantava a mão para a mãe ou o pai, hoje não, hoje o filho quer matar o pai , quer matar a mãe, através disso daí, através de espancamento, vou falar pra você, a pior vida que tem é você morar com madrasta ou com padrasto, e quando os dois casais não se une dentro de casa então um começa a tirar raiva um no outro, meu pai quer bater em mim por causa da madrasta, ela quer bater em mim por causa do meu pai, então na vida do ser humano é isso ai, através da desunião dentro de casa um vai desprezando o outro. A desunião dentro de casa leva a violência. Leva a violência, principalmente hoje a violência não começa na rua, começa dentro de casa você acredita, não tem mais o espírito que tinha antigamente, um pai pelo filho, um filho pelo pai, vou te falar o real se um dia um filho meu cair no mundo da droga quero que ele chegue pra mim, senta comigo e eu fumo uns baseado com ele, falar olha meu filho vamos fumar maconha nos dois? Porque se eu deixar ele pegar o ritmo de rua então e o seguinte outro vai ensinar ele usar crack, usar cocaína, e amanhã ele vai estar roubando pra manter seu 
vicio, e eu já usei tudo isso, e eu prefiro ensinar para o meu filho o que presta e o que não presta e muitos pais hoje não tem esse dialogo com os filhos entendeu, então os filhos vão procurar os outros na rua pra entender o que é a droga, isso aqui é cocaína, isso aqui é maconha, isso daqui e crack então quem esta de fora só vai ensinar o que não presta porque não conhece o que é o vicio, e mos que já passou por esse vicio não vai querer ver um filho viciado. Jamais botaria um filho meu no crime, como criminoso eu penso assim eu quero montar tudo que for de bom no crime, pra amanhã ver um filho meu trabalhar com o que foi meu, para não passar pelo que eu passei, porque hoje em dia é fogo, quem entra não sai mais e quem fica morre. O pessoal esta entrando porque não tem emprego, desempregado, hoje os colégios não estão valendo mais nada, ninguém se interessa em colégio, vão em colégio pra marcar horário, ver as menininhas, fumar um baseado dento do colégio, a maioria faz isso, você não vê um estudante chegar em casa pegar um livro e dizer tenho uma lição de casa, sabadão estar estudando, hoje você não vê isso, os estudo hoje esta acabado, esta por fora, eu tiro por minha casa mesmo meu filho esta na $6^{a}$ serie e na $5^{a}$ entendeu e não se interessa em nada, por causa dos colégios hoje esta tudo, a maldade esta começando na porta dos colégios, então tem muita gente que vai para o colégio não com o interesse de aprender, é de ensinar a alguém a maldade, de ensinar para um outro amigo dele a maldade também, então hoje o crime esta assim esta começando na porta do colégio, o trafico esta na porta dos colégios.

Hoje é o dono da boca que vai chamar pra trabalhar pra ele de avião ou são os caras que procuram ele?

Os caras que procuram ele, eu nunca fui chamar ninguém, e sou contra os caras que trabalha pra mim pra usar droga porque a maioria dos moleques tudo procura a boca só pra ter o vicio, eu vejo ai tem uns dez moleques que trabalha comigo que e tudo viciado, é uma coisa que não quero ver isso, não quero ver meu mal não quero ver o dos outros, quero os caras subir na vida e dizer amanhã e depois e dizer eu estou sossegado no crime, porque o crime e um lugar que você entra e não sai, então eles vão entrando pensando que o crime e tudo e o crime não é pra quem quer, é pra quem tem a sorte, é um dom, se você tem dez homens e nenhum dos dez é criminoso vai só sofrer no crime, vai morrer. Vai tirar cadeia, vai virar pilantra que o crime é só pra quem tem o dom mesmo, eu sempre tive o dom pra criminoso, comecei o crime com 11 anos, eu não tinha familia, morava na rua, ficava jogando num canto, no outro, pedia esmola nas portas, então eu comecei o crime de moleque, então eu sei o que e o crime, o cara vivido hoje não, eles entram no crime pra dizer que e criminoso e o crime não e tudo na vida.

Acha que dá status.

Acha que dá status e esta enganado viu, os moleques que começa hoje com quatorze anos não chega aos vinte anos, é porque a maioria vai entrando pelo caminho errado, não entra certo o crime é assim então eu vou andar assim não, o crime e assim eu vou pisar do outro lado, só pra jogar contra o crime que um tal de partido que abriu agora o tal do PCC, então é um partido que abriu hoje que é só pilantragem os acaras só quer saber de destruir familia e matar os outros, não quer saber de dizer eu sou criminoso vou conseguir $\mathrm{R} \$ 10.000$ vou montar um mercadinho, vou conseguir R $\$ 5.000$ vou montar uma casa do norte pra minha familia trabalhar também vou tirar o meu dinheiro limpo, fica difícil isso, eles pensam tenho R\$10.000 vou comprar um fuzil, vou matar o fulano, vou comprar um metralhadora vou matar cicrano, gasta o dinheiro de pouco a pouco e vai acabar na cadeia é o que esta acontecendo com os criminosos hoje.

\section{Qual o papel da saúde na questão da violência?.}

Se chega doente, o certo é atender na frente, por isso eu encaro também a violência, a mãe fica revoltada arruma briga fácil, fácil, então eu acho que pra mim isso é errado porque pelo certo pode ter dez pessoas pra consulta, mas se chegar outra precisando? Põe no meio das dez também, acho que não é errado deixar morrer, passar uma necessidade porque não tem uma vaga, então por ai também faz uma violência. 
7. Tem mais alguma coisa que você acha que deve ser falado sobre a violência e como lidar com isso?

Hoje pra se lidar com a violência, com tanto jovem morrendo hoje como na semana passada perdi meu irmão, então é por causa da ganância, tem olho gordo, o criminoso hoje não tem vontade de conseguir alguma coisa, hoje ele tem mais o olho gordo nas coisas do outro do que ele mesmo conseguir o seu isso esta sendo a violência, antigamente você entrava no crime e conseguia uma moto, um carro, um apartamento entendeu, você era criminoso, hoje não o cara entrou no crime matou dois, três então ai ele esta sendo criminoso, então quanto mais ele matando mais ele vai dando nome e isso, é uma coisa errada hoje em dia, então a violência esta ficando alta é o velho olho gordo porque ninguém quer dividir o pão, que comer sempre o pão sozinho. Então hoje tem um trafico correndo aqui então eles não sabem falar então tem um trafico ali, eles querem matar você que já esta no trafico mili ano pra tomar seu lugar, então o crime hoje esta sendo por causa da sociedade mesmo que não tem serviço, ninguém consegue serviço, 0 estudo não esta ajudando também, então o crime esta começando logo da classe A não dos pobres, o crime esta começando na classe media que o crack esta desandado na classe media também, antigamente era só na favela você não via na classe media, hoje já mudou os pobres não esta usando mais só os ricos esta usando, então a violência chegou através da ganância, se não fosse a ganância, olho gordo e o dinheiro, tudo é pelo dinheiro, você não viu essa semana mesmo o filho matou o pai por herança. Então tudo começa hoje pelo dinheiro, a ganância hoje todo mundo esta..., dos criminosos que eu conheço eu sou o mais velho, dos moleques que esta subindo hoje, hoje ninguém pensa em te ajudar que é mais velho pra conseguir o cargo junto com você amanhã ou depois, eles pensam em matar você pra tomar o seu lugar, se fosse pra eu entrar no crime hoje eu não entrava, preferia era um pai de familia, não tenho coragem de colocar um revolver na cinta ir ali e roubar $R \$ 500,00,1.000,00$ se você vai preso por menos de $R \$ 10.000$ você não sai, hoje o assalto à mão armada se você for preso você precisa ter ao menos $R \$ 10.000$ pra trabalhar no seu caso, pra pagar advogado, para pagar uma madeira lá para as policia pra deixar você em paz, você vai sofrer na cadeia, este mete um 157 no cara por $R \$ 10,00,20,00$, 200,00 vai pra cadeia, outros matam por causa de mixaria, 121 é homicídio no mínimo é 15 anos, 15 anos o cara pega por um carro, por uma moto então hoje os caras não sabe o que é o crime, matar todo mundo mata, roubar todo mundo rouba, quero ver a hora que for preso e falar para o juiz: juiz eu matei, juiz eu roubei ai o juiz fala toma dez anos, ai quando chega lá dentro fica chorando, lá fora não tem um real obrigado ir o pai e a mãe trabalhar pra visitar na cadeia, as vezes a passagem custa $R \$ 100,00$ a mãe é obrigada a tirar de dentro de casa pra ir ver o preso e esse cara fala que é ladrão, não conseguiu nada na rua, só atrasou os outros, e na cadeia fala que é ladrão, é por isso que o crime esta um podridão em todo canto, já roubei muita gente quando era moleque, já catei posto de gasolina, eu catava carga de remédio mas a primeira coisa que a gente via era o lucro, a gente via puta $\mathrm{R} \$ 20,000.00$ dez pra cada um, então era lucro pra gente fazer um assalto, hoje a gente vê os assaltos desses bandidos ai o maximo que pega é $R \$ 5.000$ ou 6.000 pra cada um, então não compensa o roubo, se fosse pra eu roubar hoje mudava de idéia, não vale a pena ser criminoso não porque tem muita policia na rua $m$ e tudo que você consegue no crime você perde de novo, porque olho gordo não deixa você crescer. Porque a violência começa dos policia, eu pra conseguir as drogas eu comprava da policia civil, pra conseguir as armas eu conseguia da policia militar, a violência começa das policia, eu dou R $\$ 1500,00$ por mês pra civil e $\mathrm{R} \$ 1500,00$ pra militar, toda noite aqui chega dez a quinze viaturas cada uma delas pega de dez a quinze papel pra cheirar, como é que trabalha cheirado, meu filho foi pego pela policia tomou um tiro na cabeça. Um policial muito louco, muito louco deixou a arma dispara, então hoje a violência começa com a policia, ela faz hoje vagabundo ficar revoltado, de setenta policia cinqüenta são viciados na pedra e na farinha, pra você ter uma base uns trinta freguês meu são civil e militar.

\section{E essa freguesia e ruim porque não paga né.}

Não paga, porque e ruim vem só perturbar a gente, eu tenho dó de quem eles pegam na rua porque eles trabalham muito louco, bate na cara, chuta na barriga, judia dos coitados dos moleques, quando encontra criminoso é só me dá $R \$ 10.000,50.000$ o quanto o cara tiver no bolso, pega um pai de familia o coitado não tem um real no bolso quebra no meio, arrasta pra 
quebradinha lá e dá uns três tiros no cara só porque ele não tem um tostão, outro dia pegaram eu e mais três caras, estava com um celular de $R \$ 1.200,00$ que estava no colo, e estava com mais dois caras que é trabalhador, estava vindo e dei carona pra eles ai a policia me pegou na estrada né, e tinha $R \$ 2.000,00$ no bolso e dei para os policia com o celular, e os coitados só tinha passe que vinha do serviço, apanharam que nem um condenado na minha frente, ainda falei para os policial que os caras eram trabalhador: mas não tem nada pra dar pra nos mano!! Falei puta como que são tinha que bater em mim que sou vagabundo e bate nos pais de familia, não soltaram eu, seguraram meu dinheiro e meu celular e seguraram os dois caras que é trabalhador que vem do serviço, então a violência começa dos próprios policia não é pela sociedade, sociedade tem medo deles, eu mesmo tenho medo deles, é mais fácil você ser ajudado por um vagabundo do que pela policia, porque vagabundo esta todo ida na sua área você pediu pra ele pra te dar uma força, a policia vem dá um olhadinha e depois some, vagabundo fica ali todo dia, e melhor pedir pra um vagabundo da área do que pedir para a policia.

\section{Você acha que isso que a comunidade pensa também?}

Pensa também, que a policia não vem pra ajudar ela só vem pra atrapalhar, só vem aqui pra pegar um dinheiro, se souber que alguém morreu ali ou que foi assaltado ichi !! pra chegar uma viatura aqui demora, se falar que tem um acerto pra ver quanta viatura vem ai, vem um monte com a viatura ai pra buscar dinheiro, a gente fica com medo, fica com medo mesmo, toda a sociedade aqui tem medo dos próprios policia, vamos dividir trabalhador e trabalhador e vagabundo é vagabundo, eles não mais fácil colocar vagabundo na rua e trabalhador na cadeia, se vagabundo tiver na rua eles vive bem, eles vive bem porque é vagabundo, é acerto de $R \$ 5.000$. 10.000. 3.000 é melhor ser vagabundo do que pai de familia, dos dois lados hoje dá vergonha de ser vagabundo, eu tenho vergonha hoje de pegar um cano e falar que eu sou vagabundo, se eu vou para o interior assim e falar eu sou da corrida da ate medo, matar um pai de familia, seqüestrar um, cortar um dedo, isso não existe, a finalidade é você ganhar o seu dinheiro sem atrasar ninguém, o pessoal já não pensa assim hoje, o pessoal pensa em matar alguém pra criar nome, pensa que o nome e tudo, quem tem que criar nome é cantor pra vender $C D$, na vagabundagem tem dinheiro quando sujar ele sai fora, se eu ganhar dez eu quero dividir cinco com os caras pra amanhã, quando eles tiverem dez dividir comigo, se eu subir na vida eu quero arrastar um cara pra que se eu precisar ele me ajudar também, se eu subir sozinho e precisar de alguém quem vai me ajudar, a gora os caras só pensa em matar você pra tomar o seu lugar, eu mesmo estou indo embora do crime por causa disso

Esta largando mão.

Estou largando de mão, posso viver com um cesta básica mas se eu dormir durmo sossegado, porque se eu ficar no crime eu tenho que matar um bocado ai eu vou ganhar determinação e fico na policia, mas não deixa eles se destruírem por eles mesmo se fosse pra ajudar eu ajudava, mas pra ver essa patifaria um matando o outro, eu precisar matar dois ou três à toa não, fico não, porque se eu vencer do criminoso eu fico na policia, a policia não quer saber se você matou um lagarto ou um pilantra não, quer saber que você matou você vai preso do mesmo jeito.

Essa historia de matar lagarto ou pilantra como e que fica isso?

Eu por mim eu matava todos os pilantras.

Isso não é violência?

Isso não é violência porque os pilantras são um .....da sociedade, já pensou o cara entra na sua casa e levar sua batedeira seus negócios que você suou pra comprar, chegar ali e vender a preço de banana e comprar duas ou três pedras pra fumar, um cara desse merece ficar na sociedade, ir pra cadeia ele não pode, porque ele vai ganhar um ritmo melhor dentro da cadeia $e$ quando ele sair vai ser o maior bandidão, então é melhor matar porque matou pela raiz, cortou pela 
raiz já era, aqui tinha muito assim que esperava o busão ali, fazia todo mundo descer e dar o pagamento, já sabia que dia 5 era dia de pagamento, e todo mundo que descia pela porta da frente tinha que dar o pagamento, então é chato você ver um ladrão roubar um pai de familia, trabalha que nem louco pra ser roubado por um bosta que não conseguiu nada na vida porque ladrão hoje não pensa em construir um patrimônio, ele só pensa em destruir com a droga, eles só pensam em consumir a droga, o que esta destruindo hoje a sociedade e as policias e a droga é a coca e o crack, hoje o cabeção não usa mais cocaina, não usa mais crack, antes você pegava $1 \mathrm{~kg}$ de base e fazia um kg de crack, hoje você pega 30 grs de base e 50 grs de pó Royal, 30 grs de cimento é tudo misturado e vai comendo as células da mente dele, não tem mais célula mais, ela esta fazendo a coisa por coisa, ele esta estuprando a mãe, a mente dele quem comeu foi à droga, então hoje eu tenho dó que esta viciado, porque os viciados hoje estão se acabando na droga, você vê que nem roupa eles gostam de comprar mais, nem banho eles tomam, cara que e gerente de banco, tinha um gol zero, tinha caminhonete, recebia todo mês $R \$ 4.000,00$ de salário, outro recebia $R \$ 3.000$ trabalhador, nunca roubou ninguém pra usar a droga, e hoje perdeu tudo, perdeu familia, perdeu emprego e hoje não tem coragem de roubar, fica pedindo um real pra usar a droga. Eu tenho dó de todo mundo que usa a droga, pode ser um pai de familia ele deixa de comprar um pão pra comprar droga.

\section{Entrevistado: $\mathbf{P}$ \\ Protagonista da violência}

Vou te contar umas historinhas, você vai me falar se essas são vioolência ou não e vai me falar o que vier na sua cabeça sobre o assunto.

1. Um trabalhador está voltando pra casa passa na frente de um bar onde esta acontecendo uma briga, houve - se um tiro e um homem cai morto com uma bala perdida, fala sobre isso.

O que eu acho? Isso daí é...Acho uma sacanagem. Cada um está no seu serviço e uma bala atingir ele, uma sacanagem, é uma coisa que a justiça tinha que tomar providências, né? Acho uma sacanagem só isso.

2. Deixa eu te falar outra história, uma estudante voltando da escola é atacada por um individuo que arrasta ela para o mato e estupra.

Ai é o seguinte, ai não tem noção, ai não tem sentido né, não tem nem o que falar, fico até sem palavras de falar nisso.

3. Num bairro tem uma briga de dois grupos pelo domínio da área, gente de um grupo mata pessoa de uma outra turma.

Acho que isso daí é falta de união, né? É normal nos dias de hoje um bairro brigar com outro. É normal, acho normal isso daí.

Fala mais sobre isso pra mim, como e que isso acontece nas periferias.

Isso acontece através de desavenças, entende briga por ponto, ta? É assim que acontece, um vê o outro crescendo aqui e está com negocinho aqui, um comandando essa área aqui do lado debaixo e do lado de cima está começando; o grande quer derrubar o pequeno pra ficar com tudo, ele quer só pra ele, não quer que ninguém mais trabalhe, entendeu nesse setor? Culpa do nosso País - Brasil 
4. Uma criança para o pronto-socorro com o braço quebrado e uma historia que caiu da escada, um mês depois ela volta no pronto-socorro com mancha roxa pelo corpo.

Acho que dai é culpa dos pais da criança, a criança chegou machucada e depois de uma semana já volta com braço roxo, como se diz eu acho que é um abuso, acho que a mãe que é culpada, porque não tem como a criança machucou e depois de uma semana voltar toda roxa, acho que a culpada é a mãe, a mãe que está batendo, a mãe ou o criador que está criando esta criança, principalmente criança assim ser criada pelos outros e ser maltratada, isso acontece, e daí depende muito. A partir do momento que a pessoa pega a pessoa pra criar, pode ser até sobrinho ou outra pessoa que não seja parente, está arriscado a ser maltratado. Não adianta porque a madrasta não vai tratar como a mãe trata seu filho, porque se tem dois homens na família, e um é adotivo, e são diferença de anos, dois anos, ai o que acontece a criança não vale mais nada, o filho dela, ela vai passar um ano, agora a outra ela não vai querer, o mundo está tão virado, por isso que já se diz e o final do mundo, muita gente diz que quem está se acabando, é a gente, exatamente, mas o final do mundo vai chegar eu creio, vai chegar, o que fala na Bíblia é sempre, eu creio que vai chegar, mas ai é como a gente estava conversando, tem muitos casos de amigo meu que a tia criou e sofreu muita coisa, ser humilhado, coisa assim acontece. A pessoa cresce revoltada e o que acontece chega uma certa idade ele vai ter que se virar (inaudivel) e daí se torna uma revolta, às vezes em muita classe alta mete o pau na classe baixa que é a gente porque não sabe a vida da gente, não sabe o que aconteceu. Vê eu, assim hoje com jaquinho, está frio, com uma toquinha na cabeça, com uma calça, com um tênis não sabe o que eu passei, 0 que aconteceu comigo, não é por falar, fui adotado, não tive pai, não tive mãe, criado por tia e hoje estou ai, graças a Deus estou com vinte anos, mas estou vivo, mas ninguém sabe o que se passa do outro lado, a minha vida ninguém sabe o que eu passo, tem meu aluguel, se não tiver o meu aluguel estou na rua, vou sair, vou sair dar meus pulos, mas eu mesmo tenho que fazer o meu arroz com feijão, eu mesmo lavo a minha roupa, às vezes vou a Santo Amaro pra comprar um tênis ou uma calça, você passa por bairros nobres, prédios, que é Pinheiros, Santo Amaro; vê os ricos, porque os ricos não conversa com os pobres no dia a dia, todo mundo aqui na periferia não só de Itapecerica, todo lugar da periferia. Trabalho em Santo Amaro, trabalho em Osasco, trabalho na Grande São Paulo, o que acontece muita gente está na janela, muita gente não esta percebendo, mas tem sempre um olhando e criticando, às vezes uns critica, outros apóia (inaudivel) a vida da pessoa é outra coisa, que nem a senhora passa na rua e me vê, você não sabe, não me conhece, no seu pensamento se eu tivesse de chinelo com uma garrafa de pinga na mão, a senhora passasse e me visse ia dizer: olha aqui, rapaz novo, já iria deduzir, rapaz novo com uma garrafa de cachaça na mão? A pessoa só não iria saber o que se passa na vida da pessoa, mas tem muita coisa que envolve, cada um tem que resolver os seus problemas.

E por isso que eu estou fazendo essa pesquisa pra tentar entender o que passa na cabeça das pessoas.

E a senhora sabe que eu nem gosto muito de falar nesse assunto, não gosto de comentar a minha vida, mas aqui na sessão estou precisando desabafar um pouco.

Fique a vontade que eu estou aqui pra isso também.

Ao meu ver preciso desabafar.

\section{Você mora só?}

Eu moro só, eu e Deus, amigos, irmã casada que mora em (inaudível). É, sou carta fora do baralho, estou sozinho entendeu, eu me rendo, deixo o barco rolar.

Posso contar outra historinha?

Pode. 
5. O comerciante de um bairro cansado de ser assaltado contrata uns seguranças particulares, esses seguranças matam uns rapazes negros que foram apontados como sendo os assaltantes.

\section{Eu não entendi.}

Tem um bairro com comércio igual aqui, daí os comerciantes estão sendo assaltados e ficam muito pau da vida de estar sendo assaltado, resolvem contratar seguranças particular e gente sopra pra esses seguranças que quem roubou foram os rapazes negros, esses seguranças vão lá e matam os rapazes. Não foram eles?

Eu acho isso uma sacanagem porque mata sem provas, os seguranças fizeram o que?

Não sei, isso a gente não sabe da historia, muda alguma coisa se foi ou ser não foi?

Muda, que, por exemplo, se eu estou com essa blusa vermelha, estou passando na rua, cinco rapazes foram e assaltaram a casa lotérica, por exemplo, e eu estou de blusa vermelha com mais quatro amigos meus, estou passando, eles chegam e fuzila nós, fui morto injustamente.

E se tivesse sido você era morto justamente ou injustamente?

Justamente porque roubou...E outra, que a polícia esta fazendo seu trabalho. Eu acho justamente, morreu justamente você entendeu, o cara roubava, estão fazendo os serviços deles, a não ser que eles chegou e não reagiu, se reagir.

6. Você acha que os serviços de saúde podem ajudar como a diminuir a violência, tam alguma papel que os serviços de saúde pode desempenhar para diminuir a violência?

Pode, eu conheci muita mulher que trabalha no hospital e falou barbaridade do hospital em termos de falta de...Como se diz? É muita sacanagem numa parte, porque tipo assim, a pessoa está ai sendo muito maltratado tem muita enfermeira e médico que não cumpre com a sua obrigação, a pessoa está ali e ao invés de fazer o serviço certo ele vai lá e aplica uma injeção no paciente, paciente fica mais dias no hospital, dopa o paciente, já ouvi falar também (inaudivel) enfermeiro (inaudível) que passa uma semana gritando antes de chegar com uma injeção e o paciente falecer, não pode; poderia ajudar, o que acontece dos cabeças chegar, fazer um reunião e acertar isso ai?

\section{Acertar como?}

Colocar pessoas competentes, pessoas de pulso, com cursos, com estudo; a pessoa sofreu pra fazer aquilo ali pra ser uma profissão normal. O problema, às vezes, o que leva é distúrbio mental, acho que todo mundo que se forma pra médico e pra enfermeira tem que passar pelo psiquiatra, tem muita gente maldosa, parte daí.

\section{Que mais você gostaria de falar pra mim sobre a questão da violência?}

Eu acho que a violência também tem a ver com a questão de serviço, porque se o prefeito que entra em cada município do Brasil, o prefeito chegasse e fizesse o negócio certo, o Brasil iria pra frente, gerasse empregos em firmas, só que entra o prefeito e rouba tudo, rouba metade do dinheiro como o pessoal fala, eu não sei, eu não vou dizer porque não estou no meio deles, entra 0 prefeito, entra vai lá, o governo solta verba e o prefeito só rouba, não faz o que tinha que fazer, o que acontece muito é isso.

Como assim? Me explica. 
Eu acho assim, tem muita corrupção no Brasil, a própria lei está sendo o próprio pesadelo da sociedade, porque se a pessoa estiver fazendo alguma coisa errada está em cima e tem dinheiro, ele continua em cima por causa da corrupção.

Entendi. Alguma coisa a mais que você queira falar pra mim?

Não.

\section{Obrigada}

Entrevistado: $\mathbf{R}$

Formador de opinião

3. Num bairro tem uma briga de dois grupos pelo domínio da área, gente de um grupo mata pessoa de uma outra turma.

Analisando historicamente desde os tempos mais remotos sempre houve luta por território, só que naqueles tempos não era considerado violência era uma coisa comum de acontecer, hoje analisando a gente considera uma coisa comum daquele tempo, as pessoas não tinham a comunicação, mesma língua, igual hoje que a gente consegue falar com todo mundo, varias etnias então essas guerras por território hoje soa como violência porque hoje nos temos essa capacidade de dialogar com todos os tipos de pessoas do mundo, então porque haver essa disputa se nós hoje temos essa capacidade de estar dialogando, de estar buscando outras formas, naquele tempo mais remoto não existia uma outra forma, o mais forte vencia. Hoje não, a gente tem várias maneiras de estar resolvendo esse tipo de problema, igual a este de guerra de gang por território, acho que hoje seria bem mais fácil isso, creio que essa violência já é gerada mais assim por causa de pontos de drogas, acho que gera esse tipo de violência.

4. Uma criança para o pronto-socorro com o braço quebrado e uma historia que caiu da escada, um mês depois ela volta no pronto-socorro com mancha roxa pelo corpo.

Infelizmente tem acontecido assim muitos casos de violência nos lares, que ocasiona esse tipo de lesão pelo corpo, manchas roxas, braços quebrados, muitas vezes a mãe geralmente que leva esse filho, essa criança chega no hospital ela vai contar a historia dela e não é o que é verdade se não foi citada a violência é um acidente e pronto, mas na maioria das vezes não é acidente não, é violência no lar mesmo, pai, padrasto costuma espancar mesmo e causar essas leões ai nas crianças, então é complicado também, existe muita violência nos lares hoje, famílias desestruturadas e acaba ocasionando esse tipo de violência, porque se fosse um familia estruturada por exemplo que não tivesse problemas de alcoolismo, problemas sócias de passar necessidade e fome, talvez diminuisse muito esse tipo de ocorrência, mas hoje o fato a cidade exigir, centros urbanos é uma correria tão grande que os pais não tem tempo pra ficar com os filhos, e os filhos acabam crescendo mais rebeldes então incita muito um ato desse gênero violento, então a gente tem que pensar muito nessa situação porque ela acontece muito, mesmo com o estatuto da criança e do adolescente em vigor que é um perigo para os pais serem ate presos, mas mesmo assim acontece com freqüência esse tipo de violência.

5. O comerciante de um bairro cansado de ser assaltado contrata uns seguranças particulares, esses seguranças matam uns rapazes negros que foram apontados como sendo os assaltantes.

Eu vejo essa historia como mais um equivoco, o julgamento pela aparência, muitas vezes o ser humano erra muito porque julga pela aparência, só vê o exterior já julga e muitas vezes erramos feio chega a ponto de acontecer um assassinato desses, nisso eu tenho um testemunho em casa mesmo, meu irmão estava no centro de são Pulo e aconteceu um assalto no mercado e 
ele foi confundido com os assaltantes e ele foi preso até provar que ele, por pouco ele não tomava uma surra se não fosse meu pai chegar e intervir antes porque simplesmente ele se parecer com a pessoa, então acontece muito esse equívoco e as pessoas pagam com a vida infelizmente. violência?

6. Como você acha que os serviços de saúde podem contribuir para a redução da

Serviços de saúde.

Tem algum papel que você ache que os serviços de saúde podem desempenhar na redução da violência?

Eu creio quem pode ser em termos de informação porque é um lugar em que as pessoas estão sempre, seja por motivo simples ou um motivo maior, as pessoas queira ou não queria tem um contato com esse tipo de serviço público, creio que eles tenham um papel importante na área informativa, poderia levar o pessoal a reflexão através de informações, de slogans sobre tipos de violência e também no tocante a parte social porque há muita discriminação, principalmente nos serviços de saúde que também gera violência fato de você esperar hora se horas, então se tem um bom atendimento e tem também esse tipo de intercambio com a propaganda contra a violência,acho que seria uma união bem agradável.

7. Você gostaria de falar mais alguma coisa, você e professor de crianças na escola de um bairro notadamente violento, que mais você pode falar pra gente sobre a questão da violência.

O que eu diria no tocante ao local que eu trabalho principalmente na área da escolha das aulas muitos professores não escolhe essa região, por causa do medo, da fama que se criou de ser um bairro tão violento, inclusive a mídia fala muito Jacira, Jd Ângela, Itapecerica então fala se muito disso ai, mas eu creio que nos como professores, educadores e ate mesmo como cidadão nos podemos nos relacionar bem com pessoas que moram por aqui, basta a gente tratar bem, basta a gente ser educado, respeitar o limite de cada um pra gente estar convivendo sem mais problemas, isso vai muito da atitude de cada um, é de saber ate onde você pode ir, ate onde você pode exigir daquele aluno considerado problema, ou violento, acho que a gente consegue muito detectando isso e reconhecendo o limite de cada um , é um passo importante pra gente conseguir conviver num espaço que e considerado violento, porque se a gente confrontar tet a tet acho que a gente acaba incitando mais violência, porque um aluno de um lugar desse viveu desde criança num bairro considerado violento, viu muitos tipos de violência, conviveu com isso pra ele é normal pra ele, se você vai confrontar ele você não é professor naquela hora, você é qualquer um que ele viu ali e ele vai te confrontar mesmo e chagar ate numa violência extrema, creio que vai muito de cada um de nos fazer, entrar e sair, creio que a gente evita muitas coisas ruins. Eu creio que a violência de um modo geral está ligado a falta de religiosidade, a falta do divino, acho que a falta de Deus mesmo esta ligando muito a essa violência, o povo hoje não busca esta até um pouco descrente eu creio do que eu por exemplo aprendi de criança sobre Deus, porque é bom você fazer que agrada Deus isso que eu aprendi foi a base para que eu não fizesse algo violento porque eu aprendi coisas que me serviram como base e foi na parte religiosa e eu creio que Deus faz a diferença, na cultura, na educação e também um fato que origina também a violência são as famílias desestruturadas, acho quer é o principal, onde começa tudo, porque ai as crianças crescem sem parâmetro nenhum ou deixa com empregada também que não vai fazer o papel da mãe nem do pai, ou deixa com a avó, deixa com a tia ou com irmão mais velho e todas essas situações deixam com que a criança cresça sem ser cobrada de nada e ela vai criando aquelas coisas como se tivesse na frente da TV, TV ela está ligada ali e a gente assiste, na mesma hora que alguém conversa com você desliga ela continua passando ali sem interrupção e você ao mesmo tempo também pode parar, não é igual eu estou olhando pra você agora, eu estou tendo atenção com você, então a criança quando ela fica muito largada é como se ela tivesse na frente da TV, ela faz o que quer e pra ela aquilo vai ser aquilo a verdade, causa muitos problemas no futuro, o que ela vai crescer desorientada ou orientada por filmes e novelas sei lá o que mais que ela faz quando esta em casa sozinha, ou por coleguinhas e ai acaba fugindo do propósito familiar 
porque é a familia que da base de reação, estrutura, de educação, acho que o papel super importante pra evitar a violência é os lares estarem mais estruturados, familiares, familia.

Obrigado professor pelo seu tempo.

\section{Entrevista delegado G Formador de opinião}

1. Um trabalhador está voltando pra casa passa na frente de um bar onde esta acontecendo uma briga, houve - se um tiro e um homem cai morto com uma bala perdida, fala sobre isso.

É uma situação até que certo ponto corriqueira para a polícia. O que é que acontece? O bar é um local onde se vende bebida alcoólica. A bebida alcoólica é um dos fatores que gera a violência e agressividade e às vezes acontece de um trabalhador normal, uma pessoa que está voltando para casa do trabalho estar passando ali numa hora de uma briga de bêbados, um deles saca uma arma, dispara e pega numa pessoa que não tem nada a ver com aquela briga. Então o bar é o local, o foco propício a gerar violência em razão da venda de bebida alcoólica e da aglomeração de pessoas de condições sociais não as melhores como nós desejamos.

2. Deixa eu te falar outra história, uma estudante voltando da escola é atacada por um individuo que arrasta ela para o mato e estupra.

O crime de estupro é, mesmo para nós policiais, o mais revoltante porque além dele agredir a economidade física da pessoa, ele agride a honra, o estado psíquico. Causa danos as vezes irreversíveis e esta situação que a senhora colocou ai de uma estudante voltando para casa e ser agarrada e estuprada, infelizmente isso é muito comum principalmente na periferia. Pessoas que moram em locais mais afastados na periferia, estas jovens estão mais sujeitas a isso e é considerado crime hediondo, e esta situação é uma situação que ocorre freqüentemente.

3. Num bairro tem uma briga de dois grupos pelo domínio da área, gente de um grupo mata pessoa de uma outra turma.

Isto ocorre aqui em São Paulo principalmente por dois fatores: ou disputa de área restrita à venda de drogas, então são 2 grupos de traficantes rivais guerreando entre eles para que 1 deles predomine naquela área para a venda de drogas. Outra situação dessa que acontece são brigas de gangues, uma querendo expulsar a outra, invadir o território da outra. Estas gangues geralmente envolvem delinqüentes juvenis, adolescentes viciados ou deturpados em sua personalidade de qualquer forma. Então são 2 casos que conheço de disputa de território.

4. Uma criança para o pronto-socorro com o braço quebrado e uma historia que caiu da escada, um mês depois ela volta no pronto-socorro com mancha roxa pelo corpo.

Isto aí normalmente é sintoma de maus tratos à criança que ocorre no seio familiar.Por diversos fatores a criança sofre violência por parte dos pais, parentes ou de irmãos mais velhos, da família e quando chega no pronto socorro inventa que caiu da escada ou caiu da mesa ou da cadeira ou caiu do muro. Isto tipifica maus tratos ocorridos em família que também é muito comum. 
5. O comerciante de um bairro cansado de ser assaltado contrata uns seguranças particulares, esses seguranças matam uns rapazes negros que foram apontados como sendo os assaltantes

Bem é uma outra situação que ocorre principalmente na periferia, nos bairros mais violentos como o jardim Ângela, Santo Amaro na zona sul de São Paulo, os comerciantes não têm por $n$ motivos o apoio que eles gostariam de ter por parte do estado, da polícia então como eles não têm a proteção que eles acham que deveriam ter e talvez fosse a ideal, eles contratam seguranças particulares que realmente eles procuram fazer justiça pelas próprias mãos e normalmente os mais atingidos são os pretos e pobres, isso também é muito comum. violência?

6. Como você acha que os serviços de saúde podem contribuir para a redução da

Eu acho que para se reduzir a violência,tem que haver uma somatória de esforços. Toda sociedade desenvolvida ela é calcada em cima de três fatores fundamentais que é saúde, educação e segurança. Se o estado não oferece à família condição digna de subsistência, então os pais não podem prover os filhos nas necessidades básicas de vitaminas, cálcio, proteínas, esta criança no desenvolvimento mental dela já vai ser afetado, então não vai ter o desempenho escolar desejável, ela vai ter deficiências de aprendizado. Esta deficiência pode causar complexos, causar uma, causar um certo complexo e um isolamento social. Este isolamento social pode levar à delinqüência. Então é isso, eu acho que um fator está ligado a outro.A sociedade desenvolvida ela tem que ter um sistema de saúde decente e no mínimo aplicável à grande maioria da população,a educação também tem que ter, tem que ser feita de uma forma consciente, e acessível à todos. A educação se ela for bem desenvolvida, depois da saúde, vai gerar menos violência pois a pessoa mais esclarecida ela vai ser menos propensa a praticar ou receber uma violência, vai estar mais bem preparada para a vida. Ao par de tudo isso, o estado tem que oferecer condições de trabalho, lazer, tem que haver mais vontade política, existe muita demagogia, muita hipocrisia por parte do estado. Toda esta somatória de fatores enfim,levam à crescente violência que estamos vendo aí. Isto aliado à impunidade, à esta inversão total de valores. Se fala muito em direitos humanos, mas o que vemos ai é a apologia dos direitos humanos para bandido. Você não vê a apologia dos direitos humanos para uma vítima de latrocínio. A senhora acabou de citar, o cidadão está voltando do trabalho, passa em frente a um bar e está tendo uma briga e morre por uma bala perdida eu nunca vi um padre, destes dos direitos humanos ir rezar uma missa de corpo presente para a família e oferecer ajuda para a viúva e aos filhos. Só se fala em bandido. Uma inversão total de valores, um caos social que aí está, aliado a todos estes fatores negativos. Então, o que gera a violência, o que aumenta a violência são todos estes fatores conjugados de forma negativa. Então eu acho que principalmente o que tem que haver é vontade política. Nós vemos aí um monte de políticos demagogos, hipócritas. Na hora de campanha eles: " a violência, a segurança" fazem aquela apologia toda mas nós não vemos nada de concreto. Nós vemos leis, este país é o país que mais fabrica leis no mundo inteiro, e onde menos se cumpre. A maioria das leis aqui é feita para a Escandinávia, para a Suiça, para a Suécia; não é aplicável neste país onde não existe ainda preparo intelectual,não existe cultura que faça o povo aceitar este tipo de lei. Então é o país onde mais se fabrica leis e onde menos se cumpre, onde mais se vê impunidade. Hoje mesmo eu vi no jornal 4 pessoas que foram presas com 38 quilos de cocaína. Foram para a rua, o juiz colocou na rua porque não se obedeceu o prazo legal de instrução do processo que é de 81 dias. Por que? Porque a cadeia não apresentou no fórum os presos. 4 audiências e não apresentaram nenhuma vez,por traz disso tem um monte de coisa. Estes traficantes têm o poder econômico. Eles provocam esta situação e o estado se sente impotente diante disso. Tudo isso vai gerando descrédito nas instituições, no poder público que é mais um fator a gerar violência. O que esta sociedade precisa entender e acordar é que tudo isso é um problema total, é uma globalização dos problemas que geram a violência. Não adianta atacar um problema estanque: o menor carente, o menor abandonado, o menor delinqüente. Ele é um produto do meio, da própria sociedade. Então a sociedade tem que entender que tem que trabalhar como um todo. Não existem coisas estanques na sociedade. Os fatores que geram violência são todos estes e mais alguns que podem ter me fugido agora. Onde não há saúde, não há educação, não há segurança, não há 
trabalho, não há lazer, há impunidade, as leis são obsoletas, Há uma inversão de valores, não existem condições dignas de vida, isto gera violência e aliado a tudo isto essa corrupção política que nós vemos ai a todo momento, tudo isso gera violência. Então a polícia paga por todos estes fatores tudo cai em cima da polícia. A polícia é ineficiente. A polícia tem seus defeitos? Tem suas mazelas? Suas carências? Isto é óbvio que tem. A polícia é feita por seres humanos e os seres humanos são carentes e falhos por natureza. Mas a sociedade é uma só. Nós todos somos a sociedade. Eu sou um delegado mas eu sou um cidadão e enfrento o mesmo problema que todo mundo. Eu acho que tem que haver principalmente uma conscientização coletiva da sociedade destes fatores que têm que ser combatidos como um todo. Não de forma esporádica ou estanque ou isolada. Tem q eu haver uma consciência coletiva e se combater isso de uma forma concreta e eficaz e na minha opinião pessoal há que se conscientizar a classe política. Na minha opinião os maiores problemas deste país hoje chama-se classe política.Pode ser até que eu esteja errado mas é a minha opinião.

\section{7. Que mais você gostaria de falar pra mim sobre a questão da violência?}

A violência é gerada por diversos fatores e na minha opinião os maiores fatores que geram a violência é concentração de renda,má distribuição de renda.São três fatores que mais geram violência: má vontade política, Concentração de riquezas e má distribuição de rendas. Os fatores são todos políticos e sociais. Quando não se combater estes fatores de uma forma realmente eficaz, a violência nunca vai reduzir. Então terminando, na minha opinião os três fatores que mais geram violência é o fator político, o fator concentração de riqueza, e o fator má distribuição de renda.

\section{Entrevistado: Dona J Formadora de opinião}

1. Olha: Um trabalhador está voltando pra casa passa na frente de um bar onde esta acontecendo uma briga, houve - se um tiro e um homem cai morto com uma bala perdida, fala sobre isso.

Eu acho violência, sabe porque se você esta na frente de um bar uma pessoa passa é problema, é problema, eu não tenho muito pra falar, nunca fui atingida por essa parte mas eu acho que é violência apesar de tudo que usa, da arma que usa, mas tudo é violência.

2. Uma estudante voltando da escola é atacada por um individuo que arrasta ela para o mato e estupra.

Ah eu sou revoltada com isso, ah mas eu sou mesmo revoltada eu acho que a mulher na sociedade deveria ter um, papel melhor, porque uma mulher estuprada ela é marcada para o resto da vida, porque essa violência você não só sofre na rua, mas você sofre dentro de casa este tipo de violência enquanto as varias mulheres e sujeita aos maridos fazer isso - estuprar, isso não tem perdão, isso ai não tem perdão, pra mim não tem, é o pior crime que existe na terra é isso ai, eu não admito, eu não admito, eu não admito esse crime de estupro, eu não concordo, eu acho repugnante, eu acho repugnante, esse crime ai eu acho melhor matar, é melhor matar que estupra, eu acho.

3. Num bairro tem uma briga de dois grupos pelo domínio da área, gente de um grupo mata pessoa de uma outra turma.

O pior é isso, é o mundo que nos estamos vivendo eu não concordo com nenhum tipo de agressão nem de violência, eu não concordo com nenhum tipo de agressão, agora o que eu falo pra você o que atinge mais é ter seus filhos que tem que chegar dentro de casa, você não sabe 
hora que chega, quem chega, quem esta atrás, apesar de que eu não tenho esse tipo de problema na minha casa, meus filhos são uma benção de Deus, mas eu não tenho medo dos meus filhos, tenho medo dos outros, isso que eu tenho medo é um matando, estuprando, outro dia mesmo mataram um jovem ali, não tenho nada a ver, não gosta de violência, não gosto, se dependesse de mim viveria em paz.

4. Uma criança para o pronto socorro com o braço quebrado e uma historia que caiu da escada, um mês depois ela volta no pronto socorro com mancha roxa pelo corpo.

É violência, já tinha acontecido isso no posto não já, isso ai é problema, qualquer tipo de violência eu sou contra, de criança, de idoso, qualquer tipo de violência eu sou contra.

E o que mais a sra. tem pra falar sobre isso?

Eu tenho a falar isso aqui, aqui no Jacira é um lugar que você tem que andar de dia, não tem que sair de noite, é um lugar meio, fora às outras coisas que parece por ai que as outras pessoas não quer falar, não tem nada que falar.

5. O comerciante de um bairro cansado de serem assaltados contratos uns seguranças particulares, esses seguranças mata uns rapazes negros que foram apontados como sendo os assaltantes. Fale sobre isso.

Mas isso ai a pessoa não tem prova, como é que vai matar o negro, e não é só o negro porque tem branco que também assalta né, apesar de que aqui a gente nunca sofreu esse tipo de violência não, mas eu acho ai que isso e errado, é errado, como e que se fala mesmo é por causa de preconceito, eu desconheço esse papo aqui na área, aqui na área eu desconheço. A discriminação é muita contra o preto, no Brasil existe sim, tem o preconceito tem, se uma pessoa já ser de cor a pessoa já vai falando assim: é preto, porque foi o preto, mas tem brando também que faz, o branco faz, o branco faz, o branco faz as coisas também.

\section{Como você acha que os serviços de saúde podem ajudar a diminuir a violência?}

Eu vou dizer pra você que o posto de saúde dali tinha que melhorar o atendimento, quando eles estavam fazendo pesquisa eles me perguntaram porque lá no posto já aconteceu muita coisa viu, já aconteceu muita coisa que todo mundo sabe sobre violência, já mataram gente lá dentro, mas eu acho que o atendimento lá no posto de saúde se fosse um dos melhores seria melhor, porque ali tem neguinho que você chega ali no posto de saúde, que nem o cara foi lá e obrigou que o medico fosse atender ele puxou um revolver e falou: você vai me atender ou não vai me atender, quer dizer quem trabalha não tem culpa, de chegar uma pessoa armada e apontar a arma você é obrigado a atender, nessa situação ai eu acho que Itapecerica da Serra deveria agir mais, acho que deveria ter mais segurança, mais policia, uma coisa assim que viesse a melhorar a situação, uma dona de casa vai lá de noite, por exemplo eu tenho medo de ir lá no posto de saúde de noite, se tiver alguma coisa eu digo só vou de manhã, já previno alguma coisa que acontece ai mesmo porque ai tem acontecido muita coisa. Eu acho assim, que deveria apelar para a segurança, uma policia ostensiva, isso ai eu acho que mudaria, uma policia ostensiva no posto, um atendimento muito bom, porque às vezes as pessoas vai ali apara o posto e não sabe nem quem esta com problema, quem vai ser atendido, ai já é ameaçado entendeu, uma policia ostensiva, um atendimento melhor, eu acredito que quando o atendimento é bom não tem agressão, agora se não for bom tem agressão sim, é por parte de mulher, por homem, quem é bandido, quem não é mais.

\section{Que mais você gostaria de falar pra mim sobre a questão da violência?}

Eu vou falar, do jeito que nos estamos e difícil ate você falar na violência, porque a violência não esta só na rua, esta em casa, esta na rua, esta em todo lugar, e eu acho difícil combater assim por exemplo à noite porque você esta em casa você não tem segurança em casa, 
esta na rua não tem segurança na rua, você vai para um medico você não sabe se de repente você vai ser morto lá dentro, eu acho difícil, é complicado, eu acho assim né, como eu falei que em tudo teria um atendimento melhor em tudo, tanto na policia ostensiva, como no atendimento porque quem é agredido uma hora faz quente, na saúde em geral eu acho assim que se tivesse um atendimento bom que qualquer pessoa que chegue ali não demorasse atender, não tivesse aquele preconceito porque tem, porque tem, em todo canto tem preconceito, outro dia eu fui no posto de saúde preconceito aqui do posto de saúde, outro dia eu fui no posto de saúde e tive que fazer um barraco, não fiz barraco pra mim eu fiz barraco para os outros, se tem um funcionário no posto e ele vira assim no caso que você vai pegar remédio, e eu vi, eu a vi com esses olhos que a terra há de comer um dia, eu a vi, então eu chego lá e vou ser atendida, esta puta com o dedo assim na fila vocês vão ter que me aturar não é por ai, porque se uma pessoa esta armada ela atira, e se ela atira depois a pessoa morre e como e que fica ? Não por mim, não por mim eu fiz pelo outros porque eu não agüentei a humilhação, então se em qualquer um dos postos de saúde nos tivéssemos um atendimento bom, de qualidade porque a gente e discriminado por não ter convenio, eu tenho convenio da minha filha mas eu brigo pelos outros, porque se nos tivesse um bom convenio nos não precisaríamos enfrentar o posto de saúde, tem mãe que vai revoltada, tem pessoas que vai puxar a arma lá pra dentro que já puxou para um vizinho meu, puxa arma e diz você vai me atender, a pessoa que fica do outro lado do balcão eles acham que são donos da situação, se eu tiver um padrinho lá eu sou bem atendido e se eu não tiver eu não sou bem atendida, isso eu acho uma vergonha, uma humilhação você precisar dos remédios, esta aqui op remédio, então porque você não dá para o moço ? Vocês vão ter que me aturar aqui , isso e coisa que se fale? Eu não agüentei fiz um barraco lá no posto do remédio, agora uma pessoa que vai lá querer um remédio que não tem condição de comprar, é como eu falei vai agressão, vai lá brigar, lá vai outra mãe brigar, lá vai outra, é como eu falei se tivesse um bom atendimento nas repartições publica, no posto de saúde aonde a gente fosse, eu acredito na educação, eu acredito nela, eu acredito na educação, porque se pessoa vem pra brigar você atende ele direitinho ele não vai brigar com você, agora se a pessoa já vai doente, já vai sem saber pelo menos se vai ser atendido, chega lá quem esta lá do outro lado do balcão, como foi que eu vi: vocês vão ter que me aturar se quiser pegar remédio, o que é isso não existe. Estou revoltada com essa situação do posto sempre eu brigo, agora eu acho dra Raquel que em qualquer hospital independentemente da gente ter ou não eu acho que todo mundo tem que tratar o outro bem, porque tratando bem a educação vale, se eu não for agredida eu não vou agredir ninguém, eu acho isso que o povo tem que se conscientizar mais, em qualquer lugar publico atender as pessoas bem, ate criança, se a criança esta nas drogas que eu conheço também muitas que esta nas drogas, se conscientizar bem a criança sai das drogas, tudo e falta de compreensão, os pais meio que empurra os filhos para o mundo. Porque tem muito pai, tem muita mãe que o filho esta em casa, põe o pai pra lá: vai embora some de dentro da minha casa! O filho começa a roubar, começa a andar com arma, e ai cadê os pais e é por ai eu conheço que tem ais que põe o filho com 14 anos 12 anos, não é o meu caso mas é dos casos que eu conheço, têm filhos com 12, 1314 anos, essas crianças não vão arrumar emprego porque sociedade não dão emprego pra eles, e ai o que os pais faz vai pra rua, que tem um ali que soltou o filho pra rua e o que o filho virou? Bandido, daqui a pouco é policia na porta, é o filho dele pegado com revolver e é por ai, então eu acho que deveria dar uma assistência melhor para a juventude, para os adolescentes e é por ai que é, falta de estudo, um estudo melhor, um conhecimento básico, um emprego pra cada um, que ganhasse pouquinho mas que tivesse o suficiente pra eles ganhar o dinheirinho deles. Eu acho, se você cuidar do jovens você tem um futuro melhor da fé, eu acho isso, se um dia eu fosse candidata eu nunca pensei nisso e nem vou pensar, mas a minha prioridade seria educar a juventude, assim fazer uma reunião com os pais cada dia no mês, conversar com os pais dos adolescentes, em cada canto cada lugar agrupasse 0 jovem, conversasse, desse uma boa orientação, tanto os pais como os jovens, tem pai que precisa porque não sabe educar jovem, tem pai que precisa ter uma reunião boa pra conversar sobre seus filhos, a juventude e carente, não pense que a juventude que anda nesse mundo de meu Deus é carente, eles vão para o roubo porque eles são carentes. Carentes de tudo, são carentes de emprego, carentes de pai e mãe, os pais separados, a mãe separada, a bebida que é um problema dentro de casa, é um problema dentro de casa, esse tipo de violência eu sofro aqui dentro de casa e já sofri muito, é um problema se tiver uma mãe que tenha cabeça como eu os filhos vai bem, e se não tiver, a juventude dra. Raquel esta na estrutura da familia, esta na 
estrutura dos pais, tinha que ter uma orientação boa, reunião, conversa com os pais, e muito importante.

\author{
Obrigada Dona J.
}

\title{
Entrevistado: B \\ Profissional da saúde
}

1. Então, assim, um trabalhador, voltando para casa, passa na frente de um bar onde está acontecendo uma briga, ouve-se um tiro e o homem cai morto por uma bala perdida.

Esse tá difícil. Do jeito que está a violência, precisa ver o local que ele mora, a situação onde ele está passando ali, né? Não sei como explicar isso para a senhora. Precisa saber o que está passando nessa hora que teve essa confusão. Precisa ver se ele tinha alguma amizade com alguém que estava nesse bar aí, parou para ver alguma coisa que estava acontecendo lá. Álcool, bebida, a pessoa está no bar tomando uma cerveja, sei lá, arruma uma confusão, e tem arma, tá armado e a pessoa está passando na rua e não tem nada a ver com nada, começa a discutir ali com o pessoal que está dentro do bar e sei lá, atira e acaba acertando a pessoa que não tem nada a ver. Isso acontece, né? Isso, a violência (...) a gente convive com tantas coisas que acontecem aí, semelhantes, mas é difícil também.

\section{Mas acontece muito isso?}

Acontece. Acontece, lógico, principalmente aqui na periferia, né? Acontece muito isso daí. Muito mesmo. Álcool, droga, a pessoa não tá nem aí. O pessoal está ali tomando uma cerveja, um vai usar uma droguinha, a pessoa quando tá no começo de tomar uma cerveja e não usar droga é uma coisa, depois que usou e bebeu, se transforma rapidinho, com uma coisinha de nada mesmo vai arrumar confusão e se está armado (...) então acerta alguém que não tem nada a ver. Acontece mesmo.

2. Uma estudante estava voltando da escola e é atacada por um individuo que arrasta ela para o mato e a estupra.

Isso aí, eu não sei como responder essa história. Precisa saber, o nível dessa pessoa que pegou para estuprar. Precisa saber se é uma pessoa normal, se tem esse vício mesmo, se é estuprador ou alguma coincidência. Estupro acontece muito, isso aqui, mais uma vez, principalmente na periferia deles, em locais assim distantes, acontece bastante. Principalmente por esse desemprego. Por causa de saber que é um cara que não tá tendo a chance de arrumar um serviço, fica com a cabeça desocupada, sem alguma coisa para fazer, sei lá, bate um desespero uma hora, se interessa por uma menina dessa, a menina não dá bola para ele; perde a cabeça, sei lá. Deu uma vaciladinha, alguma coisa assim, uma oportunidade dessa, ele acha que é o caminho certo. Não sei, uma coisa bem difícil, não sei se está num eixo certo para responder se é certo ou não. A violência tem que, sei lá, a violência, tanta violência que sei lá, uma pessoa que está com a mente assim vazia, sem fazer nada, sem ter uma ocupação. No caso de um estupro, sei lá, de um assalto, alguma coisa assim, a pessoa está sem um dinheiro para comprar alguma coisa e tal, então entra no desespero, via mesmo fazer alguma coisa errada e então é isso. 
3. Num bairro, tem uma briga de dois grupos pelo domínio da área. Gente de um grupo mata gente do outro grupo.

Disputa, né? Disputa, principalmente se envolver a droga. Disputa de ponto de droga, de domínio do bairro que seja, da rua que seja, se enfrenta mesmo, o pessoal se enfrenta mesmo para matar e tomar ali e ficar por cima. Isso acontece muito, até aqui mesmo acontece muito isso daí. É um matando o outro, é uma coisa muito, quem puder mais e chorar menos. Matam mesmo e tomam isso daí como poder mesmo, né? Principalmente aqui, no Jacira tem bastante isso daí. Pessoas que tem a turma dele num ponto e o pessoal do outro lado. Sei lá, aquela turma dele ali, aquela boca não tá dando ponto, o de cima está dando mais, então o pessoal vem e entra em conflito um com o outro e acaba matando mesmo para no final dominarem tudo, ficar por cima. $O$ dinheiro, o dinheiro e o poder, né? Ser, tipo assim, ser o chefe, dominar ali e ficar por cima de tudo. Tem muito mesmo. Dinheiro acima de tudo, dinheiro e poder, né? A ganância. Isso tem.

4. Uma criança é trazida para o pronto socorro com o braço quebrado, e uma história que contam é que ela caiu da escada, um mês depois ela volta para o pronto socorro com manchas roxas pelo corpo.

Essa é uma questão de violência bem delicada, a família. Tem certeza de que se acontecer isso daí mesmo, pai, a mãe, usuário de droga, sei lá, álcool. Isso aí acontece também, muito. Contam uma história diferente para livrar uma coisa, uma ocorrência, e aí volta a acontecer a mesma coisa, não tem em quem descontar, não sei, uma depressão, uma coisa bem mais forte mesmo e acaba fazendo isso daí mesmo. Acontece também. Por causa de droga, álcool, acontece muito. Desconta na criança que não tem nada a ver. Depressão, sei lá, a pessoa está com, por exemplo, está usando alguma coisa que terminou, ou não tem mais como comprar ou não tem assim, (...) acaba entrando em depressão, aquele desespero ali, a criança não tem nada a ver, por uma ou outra coisa começa a chorar ou a reclamar de alguma coisa; não tem o que fazer e acaba descontando na criança. Eu vi um monte de vezes. Acontece isso aí.

5. Uns comerciantes, no bairro, cansados de serem assaltados contratam uns seguranças particulares. Aí esses seguranças particulares matam uns rapazes negros que foram apontados como sendo os assaltantes do bairro.

Principalmente para negro, né? Seria a parte do racismo também. Falta muito treinamento, experiência, né? Principalmente segurança que faz isso daí, tem que ter uma visão certa se foi a pessoa mesmo, sem ter uma certeza. Errado, sem procurar a policia, alguma coisa, né? Tá errado, né? Pode ser a justificativa da violência contra a raça negra. Segurança assim para fazer, chegar lá e atirar e tal está errado. Agora se o segurança está ali para ajudar, orientar, tudo bem, mas fazer a justiça com as próprias mãos também é errado demais. Tem muito, muito mesmo, principalmente, mais uma vez, na periferia que eles estão fazendo. Estão contratando muito segurança, principalmente segurança que mora no próprio bairro mesmo e já conhece a malandragem, já conhece todo mundo ali, já para evitar esse tipo de coisa. Mas quando não, acontece mesmo, suspeitou, vai lá e faz. Isso daí está errado.

\section{Você acha que o serviço de saúde tem algum papel para diminuir a violência?}

Para diminuir a violência? Tem. Também tem. Palestras, né? Palestras, reuniões, convocando principalmente esse pessoal mais conhecido do bairro, que são mais antigos, que tem um conhecimento, principalmente chamar esse donos de boca, esses traficantes que são mais, costumam dominar mais, que tem uma amizade. Reunir eles e conversar, sei lá, tentar organizar. Como no PS aqui do Jacira mesmo, muitas vezes acontecia de ter um baleado que chegava aqui, um traficante, o que fosse, a pessoa ficava com medo de ter uma represália, se ia ficar vivo ou não. Dependendo da pessoa que tem ali no PS ou alguma coisa assim, conversar. Como foi feita várias vezes reuniões com uns e outros aqui do bairro que são, para tentar ajudar a conversar. Sei lá, orientar, né? A pessoa mais experiente, fazer umas palestras. Tem vários meios de ajudar o povo. A saúde tem como ajudar muito isso daí, muito mesmo. Tem como ajudar. 
7. Você tem algum comentário mais para fazer sobre a questão da violência? Como é que você está vendo a questão da violência?

A questão da violência é que cada dia está pior, não vai melhorar. A pessoa falar que vai amanhã ou depois, entra um político, sai outro, vai melhorar, faz um projeto, não sei o que, mas a tendência é só ficar pior. Principalmente, como eu já falei, aqui na periferia, essa molecada que morre ai é traficante, o cara de 20 ou 30 anos, mas tem moleque que faz segurança nas bocas, tem moleque de 10, 15 anos, 12 anos, tudo envolvido já. Então morre o chefe, acaba ficando (...). Então é difícil, fica difícil, se envolve tudo, se envolve tudo mesmo, principalmente a situação financeira da familia, então não tem como. O pessoal fala que não, que vai melhorar, mas não melhora. É muito difícil, não melhora mesmo. Isso daí está cada dia pior. Cada dia está pior mesmo. Isso é sério, eu tenho 39 anos aqui, só que eu moro aqui no Jacira há 28 anos, da turma da minha época, se a senhora vê, dá nos nervos, quem realmente está vivo ainda e tem alguma coisa para contar sobre os acontecimentos e tudo. O principal é que a maioria que se envolveu, ou se envolveram mesmo, estão mortos, e quem está substituindo sempre é um parente ou alguém que trabalhava ali, alguém da família, ou um moleque, por exemplo, há 10 ou 15 anos atrás era criança e hoje está aí com 16, 17 anos e está tomando conta. A situação é difícil, a situação a cada dia que passa está pior. A violência está aumentando cada vez mais, principalmente para a gente que mora aqui em periferia. Está difícil. Difícil mesmo. A gente tem que falar sobre isso aí, graças a (...). Tem certas coisas que a gente consegue evitar, né? Briga, às vezes conversar, trocar uma idéia, tomar uma cerveja, comer um churrasquinho, a gente consegue evitar muita coisa. Mas ta difícil, ta ficando feio o negócio, feio mesmo. Esse tal de PCC pra cá agora que não tinha. Não tinha. Esse negocio de PCC que começou agora acho que de uns 2 ou 3 anos para cá. Existia um comentário sempre, mas agora não, agora está concluído. Agora tem um pessoal do PCC que já mora por aqui mesmo, já estão dominando tudo. Está difícil, o negocio está. Aí é aquele famoso ditado "cobra engolido, cobra mesmo". Aqueles que são pequenos acabam engolidos e acaba, né, doutora, isso daí o pessoal acaba se envolvendo, como eles são uma organização muito forte, se vai fazer assim, tipo, não o meu caso, mas se vai fazer uma denúncia, alguma coisa, a própria policia, sei lá, mas tem certos policiais aí, delegados, que estão tudo envolvidos também, não adianta. Estão tudo juntos, se você fala alguma coisa, os caras já estão sabendo. Que nem aqui no PS, muitas vezes, se tem um baleado, alguma coisa, dependendo da viatura que vem fazer a ocorrência, eu como já estou há muito tempo aqui, já conheço muitos policiais, a gente não devia nem falar, tem certas pessoas que a gente tem que ficar na sua porque sabe que certos policiais já estão envolvidos também, não tem jeito. Você conhece tal pessoa? Você não sabe? Não sei, não vi, é tal pessoal que falou isso aquilo, não sei. O próprio policia ali falou, o motorista ali, me conhece, viu quem foi e tudo, mas tem que ficar livre. Quanto menos você falar é muito bom. Melhor. Eu acho complicado. Complicado mesmo.

Muito obrigado.

\section{Entrevistado: A. M. \\ Profissional de saúde}

1. um trabalhador, voltando para casa, passa na frente de um bar onde está acontecendo uma briga, ouve-se um tiro e um homem cai morto por uma bala perdida.

É problema de segurança. Eu acredito que se tivesse uma segurança melhor teria menos gente armado na rua, num bar que é um lugar público para estar matando pessoas, né? Eu só acho isso, falta de segurança e principalmente falta de educação, porque se as pessoas fossem educadas para respeitar uma a vida das outras, elas nem andariam armadas, nem estariam dando 
tiros na rua, nada dessas coisas. Eu acho que aí faltou muito a educação, a educação religiosa, inclusive, e a segurança, né?

2. Uma estudante está voltando para casa e ela é atacada por um indivíduo que arrasta ela para o mato e estupra.

Mesma situação. Eu acho que falta educação, mas educação mesmo, eu acho que as pessoas não aprendem, não aprendem o valor da vida, o respeito pelo outro ser e às vezes se descontrola por falta de educação também. Se tivesse educação sexual poderia não estar estuprando na rua.

3. Num bairro tem uma briga de dois grupos pelo domínio da área - parece coisa que a senhora conhece já, né? Gente de um grupo mata pessoas da outra turma. Fale sobre isso.

Olha ai eu acho que a situação é bem mais séria. A segurança ela não é eficiente, porque se fosse eficiente nós não teríamos duas gangues, né? Se tivesse uma já era muito né? Por outro lado, é a mesma coisa, essas pessoas estão sendo criadas sem amor mesmo, então falta amor do político, do educador, do papai que às vezes nem aparece, da mamãe, né? Falta a avó, que eles desconhecem muitas vezes, toda essa linha que poderia...Estruturar o indivíduo. Infelizmente, eu acredito que é um absurdo isso, acho que não era para ter mais, porque a gente já tem bastante informação para não ter isso, mais. Eu falo de informação assim, as notícias de controle dessas situações, estão na Internet, estão na mídia de tudo quanto é jeito. Quer dizer, se um país consegue controlar de um jeito, os outros podiam também estar seguindo o mesmo modelo, né? $\mathrm{E}$ eu acho que está um pouco devagar diante da situação, porque é séria, né? Muito séria para, eu acho que para pouco investimento nessa situação.

4. Uma criança é trazida no pronto-socorro com o braço quebrado e uma estória de ter caído da escada. Depois de um mês depois ela volta para o pronto-socorro com manchas roxas pelo corpo. Fale sobre isso.

Olha, primeira coisa, quando chega uma criança para mim, que caiu de escada, que caiu de laje, eu já tento falar com a família - olha quem tem criança e tem escada, tem a responsabilidade de não deixar cair. Quem tem laje e tem criança, tem a responsabilidade. Gente, uma laje, se você colocar 4 pilares e passar um arame em volta, a criança tem que pular o arame para cair. Mesma a coisa a escada, desce lá os 4 fios de arame e mesmo se cair o tombo é menos feio, né? Eu acho que é pura irresponsabilidade e falta de impunidade. Eu acho que se os pais levassem uma chamada,bem chamada, acho que diminuia mesmo, porque... Agora, quanto a espancamento, essas coisas, a gente sempre pensa, né? Porque essa situação se repetido, às vezes não é com um filho só. Então a gente tenta orientar ou se for o caso já comunicar, quando é sério eu, pelo menos, tento tomar providência, alguma providência, a possível.

5. Comerciantes de um bairro, cansados de serem assaltados contratam seguranças particulares. Esses seguranças particulares matam uns rapazes negros que foram apontados como sendo assaltantes. Fala sobre isso.

Ah, eu vou falar muito.

Então fale a vontade.

O problema é o seguinte, o negro, ele foi roubado da terra dele, na minha opinião. Ele, geralmente, a gente quando rouba alguma coisa, a gente acha que todos estão roubando. $\mathrm{E}$ quando o negro deixou de ser escravizado, ele passou a ser o ladrão oficial, né? De roubado que ele foi, porque ele foi roubado na pessoa dele, ele passa a ser o ladrão oficial, porque ele foi abandonado sem alimento e sem trabalho, sem cultura, uma cultura mínima para, um mínimo. Então, ele é uma pessoa assim, automaticamente, considerada um infrator, né? $\mathrm{E}$ além do mais, a raça negra no Brasil, está demorando, no Brasil, está demorando muito para se organizar. Eu acho 
que a gente podia, sei lá, ter conseguido nos organizar um pouco mais cedo, ou ainda assim, incentivar o pessoal para se organizar porque geralmente quem rouba, quem é infrator, é desorganizado, não é? Enquanto o negro morar no morro, enquanto ele não se considerar uma pessoa com todos os direitos que ela tem, ele vai continuar considerado sendo marginal. Aí eu acredito o seguinte, foi um assassinato, mataram quantos? $\dot{E}$, eu acho que isso aí assim, é vaga a notícia, então mataram alguns, alguns que eram negros, mas vai saber, são pessoas, né? Tem que ver, foram 2, foram 4, porque olha para você levar um filho até a idade de matar é uma luta. Principalmente para uma mãe, no Brasil, é uma luta desesperada, né? E quando vai começar a viver, perde a vida sem nem saber por que. Às vezes tem alguma coisa como de qualquer outra raça poderia ter, mas normalmente nem é tão comum assim o cidadão, o infrator ser negro.

\section{Como você acha que os serviços de saúde podem contribuir para diminuir a violência?}

O serviço de saúde, ele tem que estar assim, eu acho que deveria estar, constantemente ao lado do grupo onde ele trabalha, não é? E ali, esclarecendo, então, por exemplo. É a população ali em torno onde ele trabalha, né? Então vai esclarecendo as coisas, né? Então - ah, porque a criança morreu de catapora. Não, a catapora não é uma doença letal, teve alguma outra complicação. Quando a criança tiver qualquer febre, qualquer coisa, traz rápido, né? Por exemplo, na questão da violência, né? Não, espera aí, está todo mundo nervoso agora? Vamos acalmar agora e depois a gente vai conversar devagar e tudo assim. Agora, coisa brava mesmo assim, já grupos formados de bandidos, e todas essas coisas, aí é da segurança mesmo, aí eu acho que a saúde não funciona mais. Tem o papel só curar as feridas, porque depois de estabelecida a coisa. Vou te dar um exemplo, outro dia tinha um rapaz, tinham pegado um pouco de droga, então um militar pegou um rapaz que estava batendo para que ele denunciasse mais pessoas, né? $\mathrm{E}$ eu até não pude fazer absolutamente nada, mas eu fui até lá para que a coisa diminuísse, né? $E$ inclusive eu falei - olha gente, de repente alguém dessa turma está com uma metralhadora, vocês estão com revólver. Assim, mas é uma coisa muito sutil, eu podia ter levado uma tremenda de uma raspança do militar.

\section{(interrompeu para fazer um atendimento de arma de fogo)}

7. Bom, por fim eu queria saber o seguinte, tem mais alguma coisa que você gostaria de falar sobre a questão da violência?

Não, eu já falei tudo. É, porque em cada uma das situações eu falei. É falta de segurança, é falta de educação, é falta de amor ao próximo, é falta de família. Senão estarei repetindo.

Muito obrigada.

\section{Entrevistado: Dr. T \\ Formador de Opinião}

Bom, como eu te contei, eu vou te contar umas historinhas, e você vai falar o que quiser sobre essas historinhas, tá?

1. Um trabalhador, voltando para casa, passa na frente de um bar onde está acontecendo uma briga, ouve-se um tiro e um homem cai morto por uma bala perdida. Fale sobre isso.

Eu já quase presenciei um caso desse aqui perto do pronto-socorro Jacira, numa madrugada em que eu saía do plantão, Às 5 horas da manha e tem um bar aqui próximo. Eu estava no ponto de ônibus e vi, escutei rumores e era uma briga, né? E saíram duas pessoas do bar, uma atirou na outra, a pessoa caiu e em seguida o mesmo atirador aproximou-se e 
descarregou a arma nessa pessoa. Eu soube que ela faleceu, foi trazida aqui para o PS Jacira e faleceu. Como profissionais de saúde aqui no PS a gente é testemunha de casos que aparecem aqui. Geralmente o que é? Briga de bar, que mais? Casos de violência com tiro. Bom, infelizmente isso é, essa região aqui é mais ou menos super quente. $E$ isso se deve À violência mesmo, principalmente do meio, né? Do meio ambiente, da falta de educação da população, essas coisas. A população não tem opções de lazer, a família sai e deixa os filhos praticamente sozinhos em casa e eles começam a se envolver com outras pessoas que dão o exemplo e acaba essa criança criando um meio propício para a violência. Quando essa criança cresce, freqüentou pouco a escola, às vezes está viciada pelas pessoas do tráfico. E num domingo qualquer ele vai com os colegas beber em um bar e acontece uma tragédia dessas.

2. Uma moça, uma estudante está voltando para casa e ela é atacada por um indivíduo que arrasta ela para o mato e estupra.

Esse caso também é uma conseqüência da violência, né? É uma conseqüência do meio ambiente. É um produto, vamos dizer assim, do meio ambiente. É estupro, é assassinato. Esse estuprador talvez não tenha tido a oportunidade de estudar, de conseguir um emprego, talvez seja um filho abandonado, não teve o carinho dos pais e fica por aí perambulando e o que dá na cabeça dele ele faz. Caso de estupro aqui no PS Jacira não tenho visto com freqüência não. $O$ que mais que eu vou falar do estupro? Eu acho que é isso.

3. Num bairro tem uma briga de dois grupos pelo domínio da área. Gente de um grupo mata pessoas do outro grupo.

Mas isso acontece por disputa de pontos de droga, porque se eles perderem esse domínio eles vão perder o que? Dinheiro com venda de droga e então eles defendem com unhas e dentes. Se possivel matam o rival. Porque se eles perderem, se eles cederem um pouco a área deles, eles estão arriscados até a perder tudo. Acho que é isso.

4. Uma criança é trazida no pronto-socorro com o braço quebrado e contam uma história que ela caiu de uma escada. Depois de um mês depois ela volta para o pronto-socorro com manchas roxas pelo corpo.

Nesse caso podemos suspeitar de maus tratos, maus tratos, né? A gente pode pensar que essa criança, pelo fato da segunda ocorrência, essa criança ter sido empurrada da escada na primeira ocorrência e na segunda pode ter sido sofrido pancadas, traumas. A gente leva a pensar em maus tratos pela família, por parentes. Não é freqüente aqui no pronto socorro caso de maus tratos, pelo menos assim evidentes. A gente não tem tido casos. Ou, é a gente sempre pensa em maus tratos. Caiu da escada, né? Hum, hum. É, no primeiro caso pode nem ter sido. Mas isso também mostra uma falta de cuidado, de vigilância da família. Porque não colocam uma proteção na escada para a criança se proteger de uma queda, né? Num segundo caso pode também ter sido uma briga entre irmãos ou colegas e que resultou nessas manchas no corpo. De qualquer maneira você tem que pensar nos dois casos, maus tratos ou mesmo negligência da família em olhar a criança, cuidar da criança.

5. Comerciantes de um bairro, cansados de serem assaltados contratam seguranças particulares. Esses seguranças particulares matam uns rapazes negros que foram apontados como sendo os assaltantes.

Olha, pelo fato de ser negro, a gente não deve rotular as pessoas, esses rapazes de assaltantes. A não ser que tenha havido um fato evidente de que esses rapazes tenham praticado esse delito. Mas realmente as pessoas de cor negra são estigmatizadas, em qualquer e na maioria das situações de violência. Eu não posso julgar se realmente os rapazes eram assaltantes. A história diz que eram? Bom, eu acho que um segurança não tem esse direito de saber que aquelas pessoas eram assaltantes e chegar e logo matando, né? Isso aí cabe a autoridade policial prender essas pessoas e investigar. A atitude desses seguranças foi completamente errada, a não ser que 
os rapazes tivessem partido para assaltar o estabelecimento do comerciante. Mas pelo fato dele só saber que era assaltante e ir lá e matar, eu acho que não (...). Segurança mal preparado para a função. Acho que é isso só. violência?

6. Como que você acha que os serviços de saúde podem contribuir para a redução da

O serviço de saúde pode, por exemplo, quando chegar um caso de violência no serviço de saúde, fazer um trabalho de conscientização, de educação com os familiares, orientando a família para procurar, por exemplo, serviços que possam orientar, possam dar orientação aos familiares. Não sei assim como, uma maneira, mas já conversando com os familiares, orientando, já é alguma coisa. Já é um primeiro passo. E pode também levar para as autoridades informações, sobre o número de casos de violência aqui na região, que tipo de violência, a idade das pessoas que foram atendidas. O serviço de saúde pode ajudar, por exemplo, uma mulher estuprada, né? Oferecendo condições de tratamento psicológico e tratamento medicamentoso para a pessoa. Informar essas estatísticas. Porque a base da violência está em que? Educação, lazer, esporte para a população. Principalmente educação. E o serviço de saúde, acho que foge um pouco da área da saúde. (falou muito baixo)

A redução da violência foge da saúde?

É. Foge um pouco do objetivo da saúde. Pode fazer parte da assistencialista, né? Parte da assistencialista. $\mathrm{O}$ que eu penso é assim.

7. Tem mais alguma coisa que você gostaria de falar sobre a questão da violência?

É o que todo mundo sabe, a violência se origina da marginalização desse povo da periferia das grandes cidades. Não tem oportunidade de estudo, de trabalho, eles se envolvem com o que está mais próximo deles, que é o tráfico de drogas, e aí eles vão para esse submundo do crime. É, seria um trabalho de muito profissional para trazer, para resgatar essas pessoas da violência. Então o governo, as organizações sociais, todos, inclusive também a área de saúde, a área de saúde pode dar a sua contribuição, mas na parte educacional. Quem sabe, fazendo hora extra, reunindo as familias, dando palestras, já compensando a vinda aqui no posto de saúde para o tratamento da saúde e ia ver nessa ocasião uma palestra sobre a violência, né? Seria uma maneira de contribuição nossa para essa população, tá bom?

Muito obrigada, $\mathrm{T}$.

\section{Entrevistada: G \\ Profissional de saúde} sua cabeça.

Eu vou te contar umas histórias, e você vai me falar sobre essas histórias. 0 que vier na

1. Um trabalhador, voltando para casa, passa na frente de um bar onde está acontecendo uma briga, ouve-se um tiro e um homem cai morto por uma bala perdida.

É uma violência muito grande porque ele saiu atrás do benefício dele, não sabe o que está passando, está acontecendo e de repente ele é surpreendido por uma violência que deveria provavelmente ser evitado. Porque se tivesse uma segurança naquele local, pelo menos uma segurança, uma viatura, se tivesse pelo menos essa expectativa, alguém poderia fazer alguma coisa, de evitar que ele acontecesse. Tanto com ele como com outras pessoas. 
2. Uma estudante voltando para casa e ela é atacada por um individuo que arrasta ela para o mato e estupra.

É cruel, porque a gente trabalha assim tanto na área de saúde e (...) você está aguardando uma pessoa surpresa para voltar e não volta, e a revolta, o desespero, o medo. Porque quem está surpreendido, quem está dentro de casa, e quem está fora fica mais medo ainda. Porque ainda vai ser estuprada, vem aquele trauma e para que possa se recuperar daquilo é muito difícil. Tanto para quem vai pegar e acompanhar dia-a-dia.

3. Num bairro tem uma briga de dois grupos pelo domínio da área. Gente de um grupo mata gente do outro grupo.

É difícil porque você que mora perto de um lugar desse você fica com medo de sair, como trabalhar, porque que segurança você tem? Eu mesma, uma família nossa, porque como a gente está falando, até quando vai continuar esse problema? É só nosso, da sociedade, da educação, do próprio companheirismo? Ou então você faz de conta que você não está nem aí. Joga tudo para cima e continua a vida. Coloca um tampão nas vistas. E não pode ouvir, não pode falar, não pode reclamar como vai poder melhorar nossa situação. Como eu disse, nós somos cidadãos brasileiros, temos direito de tentar resolver nossos problemas, aí vem a questão. A sociedade.

\section{Como assim? Fala mais sobre isso.}

É, como assim? Em benefícios, que às vezes quer melhorar, fazer o Brasil melhor, numa pátria, um patrimônio, né? Com benefícios para que a gente possa melhorar talvez tudo, a educação, a saúde pública e outras coisas, né?

4. Uma criança é trazida no pronto-socorro com o braço quebrado e contam uma história que ela caiu de uma escada. Depois de um mês depois ela volta para o pronto-socorro com manchas roxas pelo corpo.

A suspeita principalmente é assim, se ela veio com o braço quebrado e não aparentou nada, depois a suspeita de uma violência. Até chegar à conclusão, por isso, antes disso, a gente tem que ficar atenta no movimento e olhar, e conversar com a criança, né? Observar o responsável que trouxe. Porque às vezes muitas coisas ficam a desejar. É por causa assim, se quando já entrou for tentar resolver logo, para que tenha pelo menos assim, fica assim, atento a esse tipo de coisa para que possa evitar.

5. Uns comerciantes de um bairro cansados de serem assaltados contratam seguranças particulares para resolver o problema. $E$ apontam pra ele uns rapazes negros como dizendo que são os assaltantes. Eles matam esses rapazes.

Pra esse senhor vai ser tudo perdido. Porque a tanto meio de violência e isso não vai ser só a solução. Porque primeiro tem que ter uma investigação para saber realmente se foi aquele fato ou não. Porque a gente não vai poder fazer justiça com as próprias mãos. Porque é como que fala, a violência vai gerar mais violência, e não é assim que vai se resolver o problema. Era tão bom se terminasse por aí tudo assim, mas ele vai ter que sair, vai ser mais complicado a vida dele, da familia dele. Porque vai ter aquela geração que não vai poder sair sossegado em nenhum lugar. violência?

6. Como que você acha que os serviços de saúde podem contribuir para a reduzir a

As unidades, e como é que fala? Os usuários. Equipes, médicos, auxiliares, assistência social. Procurando aceitar ao menos uma reunião com o pessoal da população. Assim, vamos se reunir, o grupo, tanto do posto, né? Eu acho que seria melhor, porque eu não sei se eu já trabalhei assim na creche, então às vezes a gente tinha o trabalho nas escolas e equipe e o pessoal da 
saúde trabalhava com o pessoal do posto. Então ali eu acho que (...) e melhoras. Então aí foi diminuindo assim, tanto o risco de orientação da saúde, evitando esses fatos de doenças, viroses, diarréias, às vezes desidratação. Esses problemas assim que às vezes dá para a gente tentar melhorar se as pessoas quiserem.

7. Você tem mais alguma para falar coisa sobre a questão da violência? Faça os comentários que você quiser.

Eu acho que também eles deveriam assim, ter uma (...) os jovens. Um trabalho mais manual, dar uma prioridade, como pra eles poderem fazer uma marcenaria, eles ocuparem o próprio espaço deles. Como que fala, não é só deixar, eu vou dar uma renda, fazer isso, isso e aquilo, uma renda bolsa; mas se ele não trabalhar, ele tem que sentir o gosto, de aprendizagem cada dia mais para que ele possa sempre melhorar também. Isso faz também que muitos saem para trabalhar porque é onde começa mais a violência, nessa faixa etária de 7 a 14 anos, que a mãe tem que sair para trabalhar, os pais saem, é aí aonde que já vai influindo pelo maior ou outras coisas, aonde que vai, né? Para a perdição, que é o roubo, curtir as drogas, que também trabalhando assim, olhando, orientando as crianças que vai para a escola, ter cuidado para não pegar uma coisa e outra, porque dos pequenos que vem os grandes vícios. Onde a gente que não. As piores coisas da fase é a, como que fala? Não sei o desenvolvimento, como que é?

Muito obrigada.

\section{Entrevistado: $\mathbf{R}$ \\ Protagonista da violência}

Como eu te falei eu vou te contar umas historinhas e você fala o que vier na tua cabeça a respeito da questão da violência.

Certo.

1. Um trabalhador, voltando para casa, passa na frente de um bar onde está acontecendo uma briga, ouve-se um tiro e o homem cai morto por uma bala perdida. Fala sobre isso para mim.

Não, comigo nunca aconteceu isso. Que eu vou falar para a senhora, sinceridade, doutora, os rapazes que me trouxeram aqui me conhecem, nós fomos nascidos, criados juntos, estudamos juntos. Eu para esse lado da violência, eu convivi nessa vida uns 20 anos e eu nunca fui agressivo, eu nunca. O meu termo, a minha finalidade era só ganhar dinheiro. Eu nunca precisei balear uma vítima, eu nunca precisei matar ninguém, agredir ninguém, a senhora entendeu? Então nesse termo assim, eu sou um cara, como se diz? Eu fui para o outro lado, para esse lado errado, por influência, mas não que eu fui uma pessoa, igual que eu conheço, amigos meus, que é amigo meu, que é violento natureza, você entendeu? Pessoas maldosas, que tem maldade no coração mesmo, que você vê. Eu não, eu não sou assim. Eu, várias situações, se eu puder ajudar, numa palavra para aquela pessoa, para não acontecer nada com ela, eu dou a minha palavra até o último, para não acontecer. Porque eu não gosto de ver o mal assim, violento, por pessoas. Então nesse termo assim de violência, igual a senhora está dando o exemplo aí dessa história, eu não sei falar para a senhora, porque eu não passei por situações, nunca me aconteceu.

Como também acontece de certas pessoas tirarem a vida dos outros sem motivo nenhum, igual a gente vê no dia-a-dia. Pessoalmente a gente mora na periferia em si e gera uma violência parece que já desde pequeno. Eu acho que é a miséria, a miséria assim já vem de pais que não dão, muitos não, muitos pais são como se diz, tentam dar o melhor, por mais pobre que sejam, você entendeu? Procuram dar uma educação, procuram pôr o filho, como se diz? Numa criação boa, só que às vezes, influencia também, devido ao lugar que mora, se deixe levar. E é tudo isso. 
2. Uma moça, uma estudante, estava voltando da escola e é atacada por um individuo que arrasta ela para o mato e a estupra.

Erradíssimo isso, nossa. Isso dai não é aceito, isso é um absurdo. Não sei nem como falar, uns caras desses num lugar que eu fiquei durante um bom tempo, sofre, viu doutora? É discriminado por tudo, não é? Discriminado por tudo e por todos, e é pessoas que em certas ocasiões, em certos lugares não tem apoio, não tem. eu só sei falar para a senhora que sofre, porque eu já vi, eu já vi vários estupradores e nossa, se dá mal. É uma coisa constrangedora, que não deveria existir, mas existe, e vai entender o por que, o que passa na cabeça do ser humano para ele fazer uma coisa dessas, né? Sendo que não precisa, não precisa disso.

3. Num bairro, tem uma briga de dois grupos pelo domínio da área. Gente de um grupo mata gente do outro grupo.

Rivalidade de facção.

\section{Fala um pouco sobre isso para mim?}

Isso aí sabe o que é? É inveja, é um querendo ter mais poder que o outro querendo dominar e acaba acontecendo isso, se destruindo, que a gente vê também no dia-a-dia, é o que mais tem. É inveja de tráfico, o que rola, tudo isso gera mais sabe por causa de que? Por causa da droga, a droga, é a droga. A droga, a pessoa, faz coisa que até Deus duvida. Eu falo para a senhora, porque eu já fui usuário muitos anos do crack, fui dependente e graças a Deus eu já me libertei há mais de 10 anos, mas eu fui escravo dele, e ele, se ele falasse faz isso, eu fazia. Então violência gera muito em torno bastante da droga, doutora. $E$ têm pessoas que se não tem drogas $e$ ela quer usar, ela faz coisa e ela não quer nem saber o que ela está fazendo, ela mata, ela rouba, ela estupra, ela faz tudo. Em prol daquilo, daquele vício. Muita rivalidade assim de grupos de bairro, de um bairro para outro é para tomar ponto de droga, porque sabe que ali é uma fonte do dinheiro, você entendeu? Então é onde que acontece. E em muitas ocasiões assim, onde as pessoas que não tem nada a ver paga. Igual fato que aconteceu aqui mesmo na padaria do Boy. Não sei se a senhora sabe, se ouviu falar. Os caras foram para matar ele, há uns anos atrás e mataram uma criança que estava dentro da padaria, mataram um trabalhador, outros dois foram baleados, que eram trabalhador também e não tinham nada a ver com o tráfico, com o crime; e ele mesmo, que era o pivô da situação não tomou um tiro, não tomou nada, tá aí de boa. Voltaram depois de 15 dias para matar ele de novo e não conseguiram matar, mataram um trabalhador no bar do lado, porque os caras tinham medo de chegar até ele perto, de matar ele, aí atiravam de longe, então atiravam de longe, e não queriam nem saber quem estava perto, quem ia morrer, quem deixou de morrer. Ele continua vivo. E várias pessoas inocentes, que não tinham nada a ver, já morreu por devido ele. Continua na ativa. Eu só não sei falar para a senhora o paradeiro. Também não me interessa, a senhora entendeu? Mas que a gente ouve, a gente ouve dos outros falar que ele continua vivo e continua na ativa. Já fugiu do Sistema várias vezes, porque tem dinheiro. Tendo dinheiro, você não fica. Você pode ficar aqui, aqui você pode ficar. Igual eu, eu fiquei 11 anos, quando eu fui preso eu tinha dinheiro, tinha casa, carro, moto, tinha tudo; mas tudo era ilusão na época, com 18 anos, para mim eu achava que era mil maravilhas e é mentira. A coisa mais bonita e importante que a pessoa, e eu fui descobrir isso, é o amor da família, é o amor de bons amigos que a gente tem, ainda tem, de Deus, você entendeu? Coisas que eu não acreditava e não enxergava na época. Só o sofrimento e vendo o sofrimento da minha família que estava passando comigo naquela situação, o dinheiro que eu tinha arrumado não valeu a pena em nada, a senhora entendeu? Eu paguei para fugir da detenção e eu não consegui fugir. Porque o funcionário catou o nosso dinheiro, foi pilantra, mandou a gente transferido. Só na Detenção eu fiquei 6 anos, aí fui transferido para a Penitenciária do Estado, apanhando, ai fiquei 1 mês trancado lá em observação, regime de observação, RO, aí fui transferido para a Penitenciária de Venceslau, que é segurança máxima. Aí fiquei lá 5 anos. Aí vim embora de liberdade, de alvará e faz 7 anos que eu estou na rua já, trabalhando de boa. Eu saí vencida. Paguei tudo o que eu devia. Já fui preso 2 vezes depois que eu saí, mas por besteira, que eu não tinha nada a ver com nada, por devido ao meu passado. Porque o passado da gente discrimina e incrimina a gente bastante, a 
senhora entendeu? O que aconteceu comigo no passado eu ainda vou paga muito tempo durante o presente, porque qualquer policial que me aborda, se eles perguntam para mim - ah, você tem passagem - eu não tenho como mentir, eu vou falar a verdade, que eu nunca vou mentir. Só que o que eu tenho eu já paguei, é o que eu falo para eles. E eles sempre falam, igual, vários já me parou e ele falou que - ladrão uma vez, ladrão para sempre; puta uma vez, puta para sempre. e não é bem assim, a senhora entendeu? Igual, eu saí da cadeia em 99, no dia 13 de julho de 99, quando foi em janeiro de 2000 , eu já tinha arrumado emprego, registrado, estava trabalhando nas Páginas Amarelas, revisa o contrato, de 3 em 3 meses eles pagavam o contrato, carimbava, dava baixa e assinava de novo. Eu trabalhei nessa empresa durante 4 anos. Eu tive uma oportunidade que um amigo deu, um amigo meu confiou em mim. Só que essa empresa faliu, faliu, eu não recebi nada. Aí um outro amigo meu arrumou para mim na Jurema aqui, que até era o diretor do sindicato que mataram, o Valério, mataram, saiu na televisão e tudo. Ele que arrumou para mim. Só que quando eu passei nos testes que eu fiz e tudo, passei no exame médico, fui aprovado e tudo, pediram os meus documentos para poder me registrar, quando viram que eu tinha passagem, ligaram na casa dos meus pais e deixaram um recado que eu não estava enquadrado no hall de funcionários da empresa. Mas por que? Por causa da minha passagem. Então é uma coisa que eu vou pagar pelo resto da vida. Só que há oportunidade e oportunidade. Eu acho que tem pessoas que merecem uma oportunidade na vida, você entendeu? Tem pessoas que já mostram mesmo, você já vê que não merecem, não merecem porque você já vê que ali não tem conserto. Tem pessoas que não tem conserto, não tem. Eu convivi com pessoas assim, por mais que você tenta ajudar, quer, mas ela em si não quer. $E$ tem pessoas que querem oportunidade na vida e não tem, a senhora entendeu? É essa a vida.

4. Deixa eu te falar, uma criança é trazida para o pronto socorro com o braço quebrado, e uma história que contam é que ela caiu da escada, um mês depois ela volta para o pronto socorro com manchas roxas pelo corpo.

Violência familiar. É, tem muito disso. Sabe por causa de que também? Álcool. Muita gente vê na periferia, que é o caso, isso é álcool, é o pai de família, é pessoa que chega embriagado em casa e não respeita a mulher, não respeita filho, não respeita pai, não respeita mãe. Tudo em torno do álcool. Gera muita violência. Tem pessoas que, ela sem beber ela é tranqüila, ela bebeu parece que ela vira um super-herói, um He-man da vida. Isso eu falo porque a gente vê. Se a senhora parar e ficar aí dentro de um bar, agora que horas são? 2 horas. A senhora vê a pessoa chegar sã, lúcida, e ela beber e daqui à 1 hora você vê o estado dela como muda. ela já fica brava, o tom de voz altera. É, já fica valente, então muita violência é entre famílias, dentro de casa, familiar, é gerado pelo álcool, a senhora entendeu? Igual eu falei para a senhora, é o álcool, a droga em si causa muita violência. $90 \%$ é isso. Eu falo para a senhora e afirmo, $90 \%$ é o álcool, a droga.

5. Deixa eu te falar, uns comerciantes, cansados de serem assaltados contratam uns seguranças particulares. Aí apontam para esse segurança particular um grupo de rapazes negros como sendo assaltantes do bairro. E esses seguranças vão lá e matam.

E matam sem provar nada. É errado. $E$ a gente vê isso também. O racismo, o preconceito e é erradíssimo. Eles têm que procurar quem? A polícia. Se tem uma lei para resolver essa situação, então deixe que essa lei resolva, não vai querer fazer segurança com as próprias mãos, porque violência gera violência. E se os amigos daqueles negros voltam e matam a família do comerciante, matam a família do segurança. e o que gerou? Mais violência, então não resolve nada.

6. Deixa eu te falar uma coisa, você acha que o serviço de saúde tem, pode contribuir de alguma forma para reduzir a violência?

Pode.

Como? 
Com certeza. E já ajuda bastante. Eu penso assim, no meu modo de ver, da violência. Eu fui operado, eu fui recebido quando eu cheguei no hospital, eu fui recebido pela saúde como qualquer outra pessoa normal ali. Eu não fui discriminado em nada do meu passado, que eu já passei, você entendeu? Ninguém queria saber o que eu era ali. Se eu era um bandido, se eu fui um bandido ou não, se eu era um trabalhador; então eles estavam ali para me tratar, para me curar, independente do que eu fosse. Então eu acho assim, já ajudam bastante. Demais, a senhora entendeu? Cuidando, independente de que seja, da onde vem, de raça, de cor. Eu acho que ajuda demais. A minha irmã está fazendo faculdade de enfermagem. violência?

7. Fala uma coisa para mim, o que mais você gostaria de me falar sobre a questão da

Eu que eu gostaria de falar para a senhora é igual o que eu falei desde o começo, doutora. Eu, assim, em termos, porque eu sou um cara da paz, eu não gosto de confusão, detesto. Não vou falar para a senhora que eu já não fiquei bravo, passei várias vezes pela minha cabeça de tirar a vida de certas pessoas, mas que me provocaram, me deixaram, mas graças a Deus, Deus foi maior e não deixou isso acontecer, a senhora entendeu? eu acho que a violência já vem lá de cima.

Lá de cima?

Dos governantes, que não dá, eles tentam ajudar, mas no fundo, no fundo, eles não ajudam nada, porque a gente vê as manchetes nos jornais, é deputado de tal que roubou tantos milhões, é presidente que desviou tantos milhões, é governador. Então isso vai gerando o que? Que as pessoas, que o povo se revolte e já gera uma violência em si. Porque a pessoa já fica revoltada e fala - que, eles querem cobrar de nós o que? Se eles lá em cima está mostrando aí todo dia que eles que roubam, que faz isso, que faz aquilo; então porque a gente não vai roubar? Não vai matar? E é o errado, né? é o que eu penso.

Muito obrigada. Desculpa eu tomar o teu tempo, eu sei que você tem compromisso.

Não, eu queria ajudar a senhora, doutora, do jeito que a senhora está precisando, igual o Alberto falou, que a senhora vai dar aula em doutorado e queria falar sobre o tema violência. Só que, igual eu falei para ele, eu não levo jeito assim para, porque eu sou meio fechado, meio calado assim para conversar. Mas eu espero que eu possa ao menos ter tentado ajudar a senhora.

Com certeza. Com certeza me ajudou muito.

A senhora entendeu? Então tá bom, doutora.

E quando você falou que entrou foi preso com 18 anos?

Eu fui preso ia fazer 19 anos e sai com 30 anos, doutora. Tô com 37.

O que é ficar 11 anos preso?

Ah acabou a minha vida, doutora. Acabou a minha vida. A senhora vê, a minha filha nasceu e cresceu, e está com 15 anos. A minha filha, ela não pode falar que teve um amor de pai, ela teve o amor da minha família, dos meus pais, porque quem foi o pai dela foi o meu pai. O meu pai que estava ali lado a lado, quando a minha filha nasceu eu estava preso, quando ela foi feita, foi gerada eu estava preso, lá na Detenção, ela nasceu em 91.

A tua mulher engravidou e você preso? 
E eu preso. Em 91. Eu fui preso em 89 e em 91 a minha esposa engravidou e em 92 a minha filha nasceu. Então quer dizer, eu perdi tudo, o que eu tenho o que é? é a minha saúde, hoje em dia, é a minha família que nunca me deu as costas, me abandonou. Eu acho que por devido o meu jeito de ser, que por mais bêbado ou drogado na época, o que eu tivesse, quando eu chegava em casa, eu sempre respeitei a minha mãe, sempre respeitei o meu pai, eu sempre respeitei minhas irmãs, os meus amigos, então...

O que você acha te levou a se drogar?

Não sei, olha, eu comecei a usar droga cedo, doutora. Sabe onde eu comecei a usar droga? $\mathrm{Na}$ escola, doutora. A primeira droga que eu usei, maconha, foi na escola, doutora. $\mathrm{Na}$ escola. Eu trabalhava, eu estudava com o Roberto, quem me arrumou o meu primeiro serviço na minha vida foi o Roberto, de office-boy. Eu tinha 12 anos, aí ele me levou lá para trabalhar de office-boy, trabalhei nessa empresa durante 5 anos com ele, no IBPG, Instituto Brasileiro de (...) e Meteorologia. Fica lá na Bela Vista. Trabalhei 5 anos, aí na escola eu trabalhava de dia e estudava à noite, e à noite eu conheci a droga, comecei a fumar e da maconha já passou para lançaperfume, do lança-perfume eu já bebia exageradamente, não era uma cervejinha, já era extrapoladamente, e eu novo, um moleque novo com 15 anos e já conhecia a cocaína e aí foi aonde eu já saí do emprego e comecei a roubar. $O$ primeiro assalto que eu fiz eu fui preso. $O$ primeiro, nunca tinha roubado ninguém, nunca, porque a minha família sempre me deu, tentou me dar do bom e do melhor de educação, de alimento, de tudo. Mas é igual eu falo, muitas pessoas vão pela miséria e muitas pessoas vão pela influência, por não ter assim uma opinião de vida definida, você entendeu? E eu por ser novo na época, eu não tinha, eu achava que tudo era mil maravilhas e não era. E quando eu fui ver eu já estava quase com 40 anos e tinha perdido a melhor fase da minha vida.

\section{Esse assalto de 19 anos foi preso por isso? Foi seu primeiro?}

Não, o de 18 anos. Eu fiz 18 anos hoje e com 10 dias eu fui preso e fui para a Detenção. Fiquei 1 mês e 15 dias na Rouba Banco, no DEIC, na época era do DEIC, da Rouba Banco, eu desci para a Detenção, e fiquei 1 mês e pouco na Detenção. Então, por devido, eu sempre (...), nunca tinha passado na FEBEM, por ter registro em carteira 5 anos, por ser menor de 21 anos, por estar estudando, por tudo isso, o Juiz me concedeu a liberdade provisória. Aí eu fiquei 2 meses e pouco preso. e eu achei que de lá para cá, eu comecei assim, disparadamente tudo o que eu fazia dava certo, eu comecei a roubar, eu comecei a roubar banco, dono da firma, e foi indo. E comprei casa, comprei carro, comprei moto, e eu entrava em cana, eu assinava o BO, porque eu entrava em cana dava um acerto para a polícia, dava um dinheiro, e assinava e vinha embora. E eu achei que ia ser sempre assim. Quando eu fui cair na realidade em si, eu já estava condenado na rua, à revelia, a 16 anos, eu já estava condenado em 3 assaltos, sem saber, eu já estava procurado pela justiça sem saber. Aí fomos catar uma mansão no Brooklim lá, a polícia cercou e eu fui. Aí quando eu fui preso que eu fui saber que eu já estava sendo procurado justiça desde 87, já fazia 2 anos que eu tava procurado e que eu tava devendo pra justiça, condenado, há 3 anos e pouco. Eu fui preso e fiquei quase 11 anos. 10 anos e 8 meses.

\section{Ai não adiantou arredar?} lamentar?

Não, aí você tem que... Se deu azar, aí você tem que erguer a cabeça e vai chorar, vai se

\section{Porque das outras vezes você falou que deu dinheiro e?}

É, mas foi tipo assim, como se diz, é que a polícia tem os bate-pau, tem os ganso deles, os informantes, então a gente catava um banco, catava uma firma e você não tem como ficar pra você. Você comenta para os outros e esse ganso ficava sabendo, bate pra polícia, a polícia, o Rouba Banco já invadiu a minha casa umas 3 ou 4 vezes. Me catou, aí eu fazia o acerto, e saía pra rua, assinava e fazia o acerto e saía pra rua. Mas flagrante assim igual eu entrei não tinha 
acerto porque chegou reportagem, chegou tudo, tinha resistência à prisão, troca de tiro. Os meus companheiros que estavam comigo. Aí não teve acerto, aí fui pra cadeia. Paguei fogo na Detenção (...), pagamos 60 mil reais, nós em 3 cada um deu 20 para o funcionário, o funcionário botou nós 3 numa mesma cela para facilitar a fuga, o funcionário catou o nosso dinheiro e não facilitou nada.

\section{E aí?}

Mudou nós de bonde. Que foi quando eu fui pra penitenciária de Venceslau.

\section{Quem é o bonde?}

Transferido. Aí fiquei 5 anos lá na Penitenciária de Venceslau, lá perto do Mato Grosso. Aí de lá aqui eu comecei, porque lá na Detenção, a droga, você tem mais acesso, mais facilidade do que na rua. Na Detenção é assim.

\section{Você estava no Carandiru?}

Estava. E na Penitenciaria que eu fui transferido, em Venceslau, não, era ritmo ditadura. Era sim senhor, não senhor. Barba feita, cabelo feito, camisa por dentro da calca, você que tinha o seu espaço para você andar, na galeria, no meio só andava funcionário, nas laterais só preso. Você tinha que trabalhar e estudar lá dentro. Você tinha que trabalhar e estudar, senão você não saía para fora da cela. Então foi lá que eu fui começar a enxergar realmente, a refletir, quem era eu, o que eu já tinha feito na minha vida. aí foi onde que eu saí com a cabeça mais formada.

\section{Você estava no Carandiru quando teve o massacre ou não?}

Fazia 4 anos já. Foi em 92, eu cheguei lá no começo de 99, de 89.

Conta pra mim, como é que é estar lá? Eu nunca ouvi ninguém que estava lá.

Eu pensei que ia morrer, doutora. Mas igual aquele filme do Carandiru, muitas coisas ali é besteira, é mentira, muitas coisas ali é mentira. Mas eu falo pra senhora, ali olha, a violência, presos desarmados, porque é mentira, não tinha nenhuma arma, não tinha nenhuma arma, é igual os Direitos Humanos falaram, era só desligar a água, desligar a luz, não tem comida, não tem nada, eles iam se render. Não tinha um funcionário com ninguém, era só preso rebelado, e eles me entram e me matam mais de 200 pessoas?

Nossa. Não era 111 que falaram?

Não, isso foi o que família correu atrás e como se diz?

\section{E reclamou o morto?}

E reclamou o morto. E muitos que foram mortos lá que já há 10 anos que estavam preso e que a família nem sabia que estava preso e foi enterrado como indigente? Porque a gente viu, a gente viu vários sair em caminhão de lixo, jogado na traseira de viatura e foi sumido. Depois de 6 dias, depois de 4 dias quando liberaram nós para fazer a faxina no pavilhão, pra desinfetar, para fazer a recontagem, foi achado corpos no elevador, isso depois que já tinha saído a listagem de 111. 111 para a sociedade que não sabe, que não tava lá. Mas ali foram quase 200 pessoas, covardemente. Pô, se a pessoa está presa, ela está pagando pelo erro dela. Como que eles entram e chegam, igual eles punham o bico da metralhadora assim, no guichê e saía matando todo mundo, o que é isso? Fazia nós carregar os cadáveres, o companheiro, e empilhar lá no esporte, e muitos que a gente estava carregando, estava ajudando a carregar e os caras matavam? Foi uma covardia em si, só por Deus mesmo. Então quer dizer, a violência já é gerada também mais por eles. Igual você vê às vezes os policiais abordam certas pessoas e já vão batendo, isso é certo? Isso não é correto. Eles estão ali para corrigir e dar exemplo. Se eles não querem violência eles não têm que ser violentos. Você entendeu? Então já vem errado de muita coisa, muita coisa. 
Você já pensou em escrever um livro da sua vida?

Não. Não pensei não.

Por que você não pensa? Está desempregado, sabe ler e sabe escrever.

Com certeza.

Você tem tanta história pra contar.

Ah tenho.

Que pode servir de exemplo para o jovem de hoje. Porque o jovem se ilude.

Se ilude.

Você bota uma arma na mão do cara e ele se sente....

Oh, ele se sente o dono da situação. e principalmente se é aquele jovem que está, igual eu, igual eu doutora, eu onde eu nasci e cresci, eu tenho uma ação de respeito só por moleques que nem me conheceram e só me conheceram agora porque eu saí, que me respeitam assim, a senhora precisa de ver. Tem eu como, na criminalidade, como um herói. Você entendeu? Você tem que se espelhar em mim, ver o que eu passei, o sofrimento que eu passei, e por quem foi eu e não ter nada hoje em dia, só ter a minha saúde, graças a Deus e a minha liberdade, aí que eles tinham que se espelhar em mim e trabalhar e ser alguém na vida. Muitos não, muitos acham que, como se diz, o que eu fui, o que eu fiz, o que eu deixei de fazer, o tempo que eu passei, muitos querem roubar, quer fazer coisa errada, e eu procuro falar para eles que tudo isso é besteira, tudo isso é ilusão. E quando você cai na realidade, muitas vezes é tarde. Muitas vezes não tem volta, comigo teve volta, porque eu fiquei durante todos esses anos e graças ao meu bom Deus eu to na rua aí, 7 anos que eu saí, porque eu tive o apoio da minha família, tive o apoio de poucos amigos, de poucos que conto no dedo; e muitos que não tem, doutora? Muitos que não oportunidade de vida, não tem? Saem e vão fazer o que? Vai roubar, não vai fazer outra coisa, porque ninguém dá emprego, não tem família, para ex-presidiário, ele vai morrer de fome? Vai deixar o filho dele morrer de fome? Se ninguém ajuda, ninguém dá uma oportunidade? Quer que se exploda - não seja meu parente, não conheço, vou ajudar pra que? A senhora entendeu? É aonde gera a violência, é aonde faz a pessoa revolta, revolta ela porque ela tem um filho, o filho está chorando porque não tem o que de comer, olha para um lado, olha para o outro, ninguém dá um apoio, ninguém dá nada; vai roubar, vai fazer besteira. É errado? É errado, mas vai fazer o que? A senhora entendeu?

Eu entendi. Pesado, hein?

Muito. Igual a minha mãe, a minha mãe se acabou doutora, porque eu sou filho único homem. Eu olho para a minha mãe hoje em dia e a minha mãe não tem a saúde que ela tinha, minha mãe hoje em dia toma remédio tarja preta, já fez vários tratamentos com psiquiatra, eu acabei com a vida dela. assim estruturalmente, assim fisicamente de saúde, da minha mãe, do meu pai, minhas irmãs. Nossa, as minhas irmãs sofreram comigo demais, demais, mas nunca me abandonaram em motivo algum, doutora. Eu não sei se é por devido eu ter sido um bom irmão, igual eu falei para a senhora, porque eu nunca fui violento, eu nunca cheguei a bater, agredir uma irmã. eu nunca fumei um cigarro na frente do meu pai. Passava até uma má idéia. e eu fumo desde os 13 anos.

Não é uma coisa estranha? Uma pessoa como você, que você tem essa relação familiar tão boa, se meter numa história dessa? 